UNIVERSIDADE DE SÃO PAULO

INSTITUTO DE GEOCIÊNCIAS

\title{
Tipologia e origem das fraturas sub-horizontais em basaltos da Formação Serra Geral, Brasil
}

\author{
Daiane Katya Curti
}

Orientador: Prof. Dr. Claudio Riccomini

DISSERTAÇÃO DE MESTRADO

Programa de Pós-Graduação em Geoquímica e Geotectônica

São Paulo

2011 
Ficha catalográfica preparada pelo Serviço de Biblioteca e Documentação do Instituto de Geociências da Universidade de São Paulo

\section{Curti, Daiane Katya}

Tipologia e origem das fraturas sub-horizontais em basaltos da Formação Serra Geral, Brasil / Daiane Katya Curti. - São Paulo, 2011.

119 p.: il

Dissertação (Mestrado) : IGc/USP

Orient.: Riccomini, Claudio

1. Geologia estrutural aplicada 2. Derrames basálticos 3. Barragens 4. Formação Serra Geral I. Título 
Dedico esta dissertação ao meu marido Francesco Barale. 


\section{Errata}

\begin{tabular}{|l|l|l|}
\hline Página & Onde se lê & Leia-se \\
\hline 16 & figura 5.4 & figura 10 \\
\hline 17 & figura 5.5 & figura 11 \\
\hline 22 & $\begin{array}{l}\text { Localização das usinas hidrelétricas com } \\
\text { ocorrência de fraturas de grande } \\
\text { continuidade lateral na região centro- } \\
\text { sul do Brasil. }\end{array}$ & $\begin{array}{l}\text { Localização das usinas hidrelétricas com } \\
\text { registros de ocorrência de fraturas de } \\
\text { grande continuidade lateral na região } \\
\text { centro-sul do Brasil, discutidas na presente } \\
\text { dissertação. }\end{array}$ \\
\hline
\end{tabular}




\section{RESUMO}

Nos derrames basálticos da Formação Serra Geral são reconhecidas numerosas ocorrências de fraturas sub-horizontais de grande continuidade lateral. Tais fraturas, de até centenas de metros de extensão, foram consideradas estruturas típicas em derrames e constituem importantes descontinuidades na estabilidade de obras de engenharia e como rotas de percolação de fluídos. Descritas inicialmente no final da década de 60 , as fraturas sub-horizontais em derrames basálticos foram intensamente estudadas até o início da década de 90, por ocasião da construção de grandes barragens sobre os derrames basálticos da Formação Serra Geral. No presente trabalho, a reunião das informações disponíveis sobre as fraturas sub-horizontais em basaltos permitiu estabelecer as relações entre suas formas de ocorrência e seus processos geradores, bem como a análise crítica dos modelos apresentados na literatura no que diz respeito a movimentações sobre fraturas sub-horizontais.

As fraturas sub-horizontais possuem uma ampla variação de características, atribuída a diferentes processos genéticos e atuação de agentes secundários. Tais estruturas podem ocorrer como simples juntas sub-horizontais bastante contínuas, de abertura milimétrica, ou constituírem horizontes fraturados com espessura decimétrica a métrica (até 2 metros), apresentando fortes ondulações. Esses horizontes são caracterizados por fraturas pouco persistentes, que delimitam blocos tabulares com terminações em cunha e em forma de lentes. As fraturas sub-horizontais ocorrem em porções específicas dos derrames: abaixo da zona vesiculo-amigdaloidal do topo; em meio ao basalto maciço, normalmente no limite entre diferentes níveis de disjunções colunares; ou próximo à base do derrame. Os diferentes tipos de fraturas sub-horizontais foram classificados dentro do quadro de eventos sin-, tardi- e pós-magmáticos. As fraturas sub-horizontais sin-magmáticas correspondem a feições de fluxo formadas devido a esforços cisalhantes gerados pela diferença de velocidade de fluxo da lava. As fraturas sub-horizontais tardi-magmáticas correspondem a juntas de resfriamento geradas pelo avanço das frentes de resfriamento que se deslocam das periferias para o centro do derrame. As fraturas sub-horizontais pós-magmáticas correspondem a dois principais tipos de estruturas: juntas de alívio e fraturas de cisalhamento. Tais estruturas podem ser neoformadas, ocorrendo em qualquer porção do derrame, ou se desenvolverem sobre fraturas sub-horizontais preexistentes. 
$\mathrm{Na}$ literatura, as fraturas sub-horizontais foram denominadas como "juntasfalhas", devido a variedade de estruturas que apresentavam correlações com feições primárias do derrame e sinais de movimentações como estrias de atrito e deslocamentos de diques e fraturas verticais. Os deslocamentos observados nas fraturas sub-horizontais podem estar associados ao processo de alívio de tensões laterais em taludes, pelo entalhamento de vales fluviais, bem como a movimentações decorrentes de esforços tectônicos regionais. Estrias de fricção ao longo de fraturas sub-horizontais preexistentes têm indicado que tais deslocamentos são compatíveis com movimentações transcorrentes na bacia. Fraturas no fundo dos vales apresentam um padrão conjugado com fraturas sub-horizontais podendo apresentar feições de cisalhamento.

Palavras-chave: Fraturas sub-horizontais, derrames basálticos, “juntas-falhas", Formação Serra Geral, barragens. 


\section{ABSTRACT}

In the basaltic lava flows of Serra Geral Formation, numerous occurrences of subhorizontal fractures of extensive continuity are recognized. Such fractures, of up to hundreds of meters long, were considered typical structures in lava flows and are relevant discontinuities in the stability of engineering works and as fluid percolation routes. Described initially in the late 60s, the subhorizontal fractures in basaltic lava flows were intensely studied until the early 90s, when large dams were built over the rocks of Serra Geral Formation. In this work, a reunion of available information on subhorizontal fractures in basalts allowed to establish the relations between the ways they take place and their genetic processes, as well as the critical analysis of the models presented in the literature with respect to movements on such subhorizontal fractures.

Subhorizontal fractures have a wide variety of characteristics, due to different genetic processes and action of secondary agents. Such structures may occur as quite continuous simple subhorizontal joints, of millimetric opening, or fractured undulate horizons with decimetric to metric (up to 2 meters) thickness. Such horizons are characterized by low lateral continuity, limiting tabular blocks with wedge and lensshaped endings. The subhorizontal fractures occur in specific portions of the flows: below the upper crust zone; in the massive basalt, usually at the boundaries between different levels of columnar joints; or near the base of the flow. The different types of subhorizontal fractures were classified within the syn-, late- and post-magmatic events. The synmagmatic subhorizontal fractures correspond to features of flow formed due to shear stress generated by lava flow speed difference. The late magmatic subhorizontal fractures correspond to cooling joints generated by moving forward of those cooling fronts displacing from the peripheral areas to the middle of the flow. The postmagmatic subhorizontal fractures correspond to two different types of structures: release joints and shear fractures. Such structures may be neoformed, and occur in any portion of the flow, or being developed over the preexisting subhorizontal fractures.

In the literature, the subhorizontal fractures were named as "joint-faults", due to the variety of structures that presented correlations with the flow primary features and signs of movements such as friction striae and displacement of vertical dikes and fractures. The displacements observed in the subhorizontal fractures may be associated with the process of lateral stress release in slopes, by erosion in river valleys, as well as 
regional tectonic movements. Friction striae along preexisting subhorizontal fractures have shown that displacements are compatible with transcurrent movements in the basin. Fractures in the valley bottoms present a pattern of conjugate subhorizontal fractures and it may also present shear features.

Key-words: Subhorizontal fractures; basaltic lava flows, “joint-faults”, Serra Geral Formation, dams. 


\section{ÍNDICE}

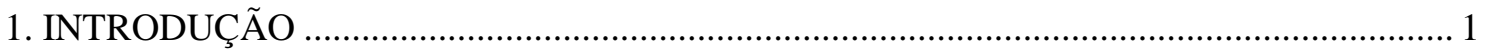

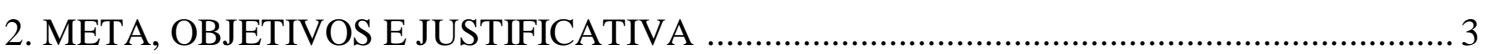

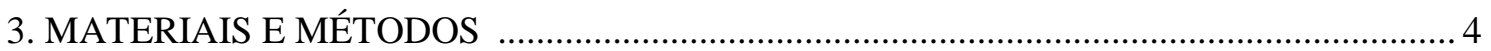

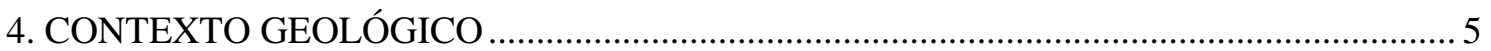

4.1. A Província Basáltica Paraná-Etendeka e a Formação Serra Geral ................................... 5

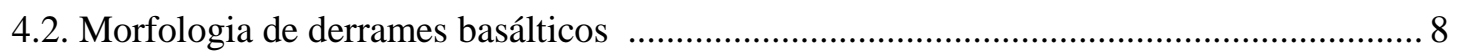

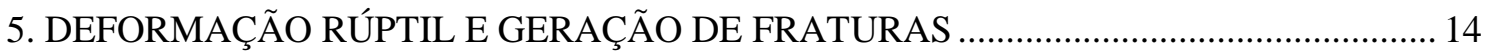

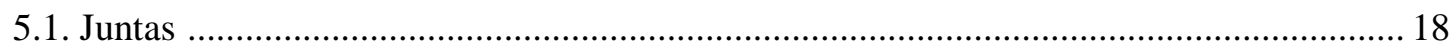

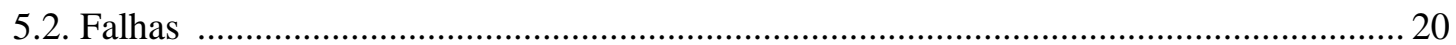

6. FRATURAS SUB-HORIZONTAIS EM DERRAMES BASÁLTICOS DA FORMAÇÃO

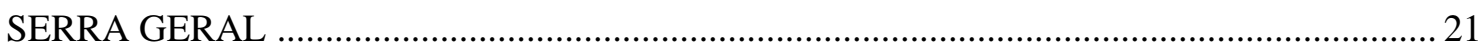

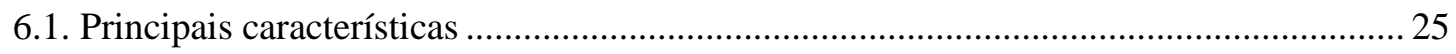

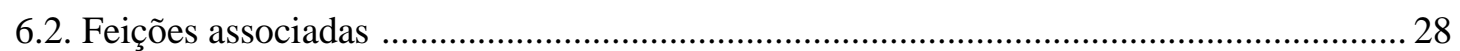

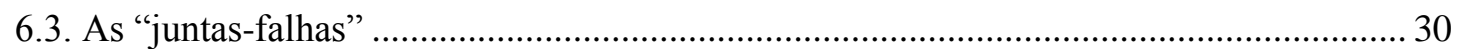

7. PROCESSOS GERADORES E DEFORMADORES DE FRATURAS

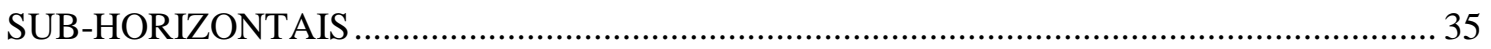

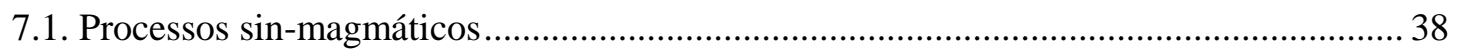

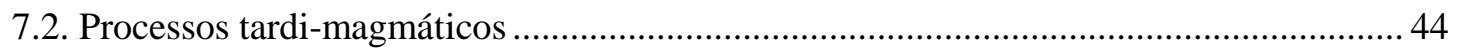

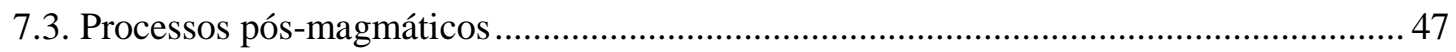

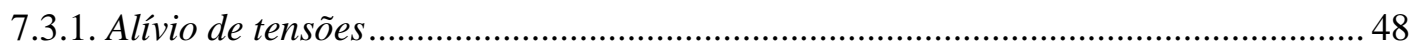

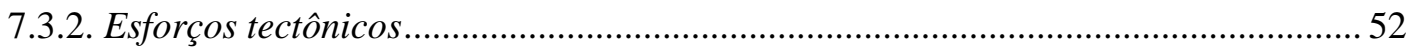

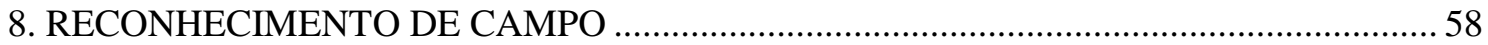

8.1. Usina Hidrelétrica de Água Vermelha (SP-MG) ............................................................. 59

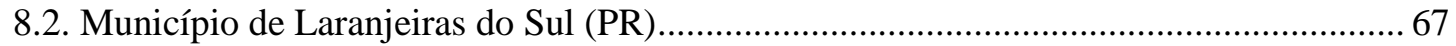

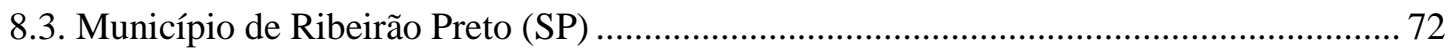

9. PREENCHIMENTO DE FRATURAS SUB-HORIZONTAIS EM BASALTO_..................... 82

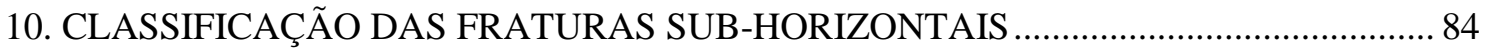

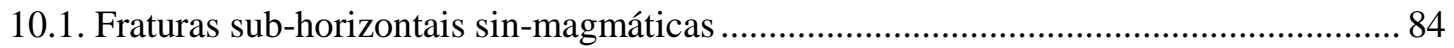

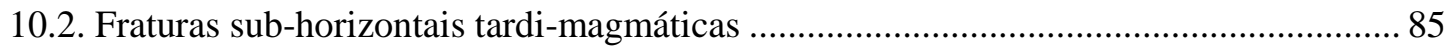

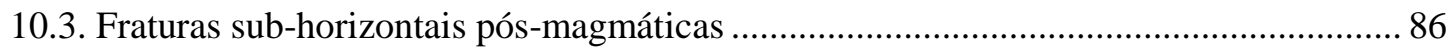

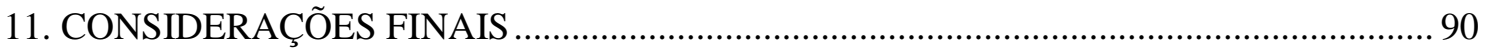

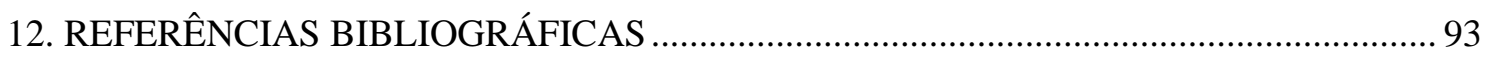

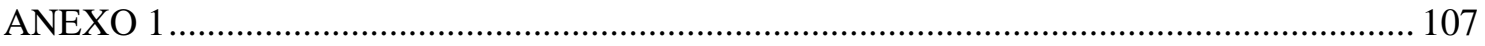

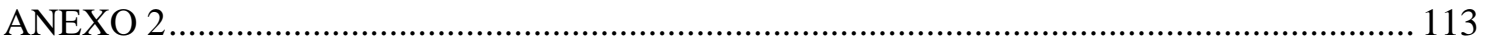




\section{ÍNDICE DE FIGURAS}

Figura 1: Localização das principais províncias basálticas ......................................................... 5

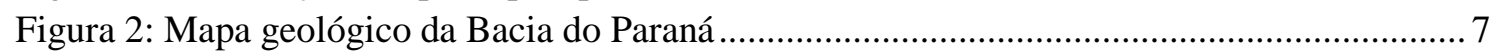

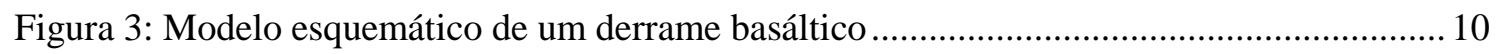

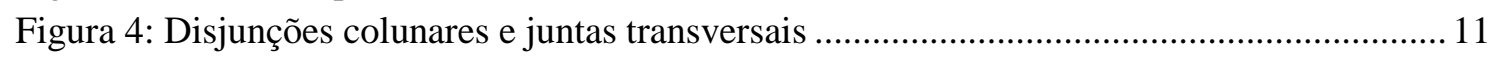

Figura 5: Padrão de fraturas entablamento e colunata em derrame basáltico da Formação

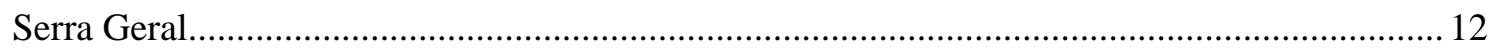

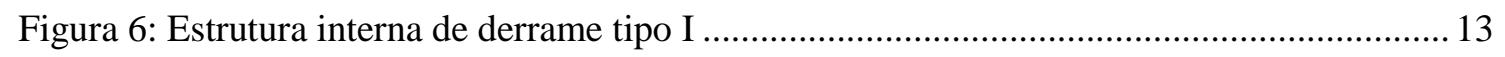

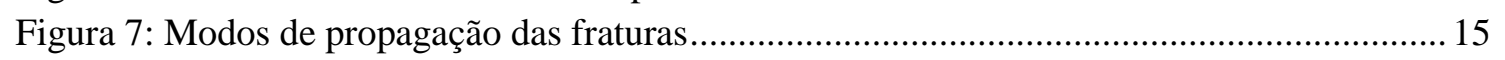

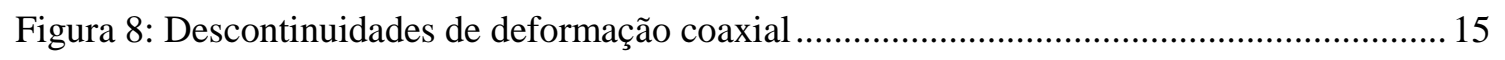

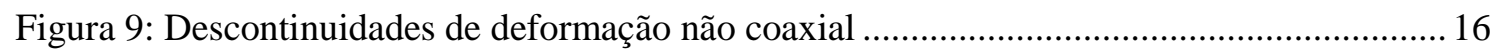

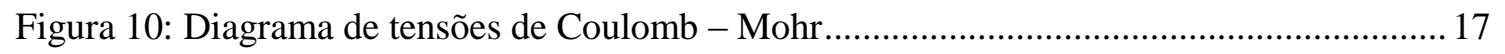

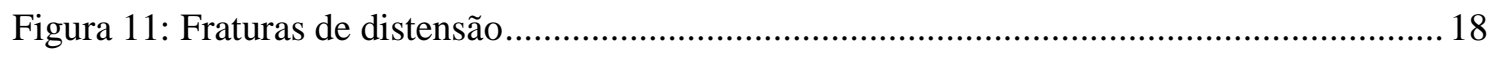

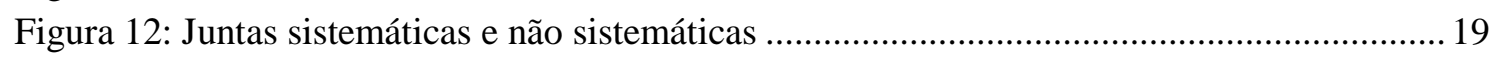

Figura 13: Localização das usinas hidrelétricas com ocorrência de fraturas de grande

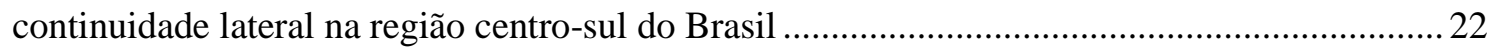

Figura 14: Distribuição da permeabilidade (K) em função da profundidade (P) ........................ 23

Figura 15: Seção esquemática do derrame basáltico, identificando as três zonas

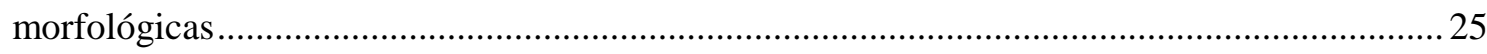

Figura 16: Modelo hipotético de um derrame basáltico com a representação esquemática

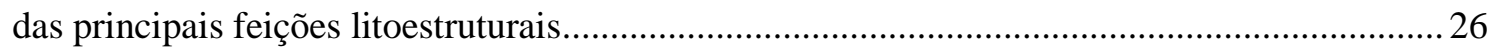

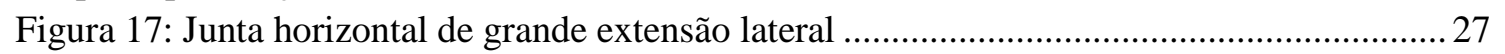

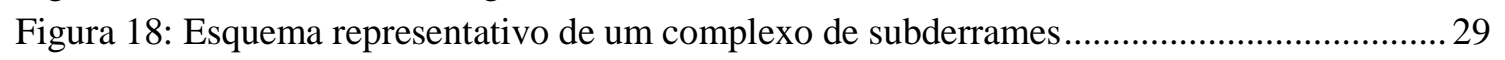

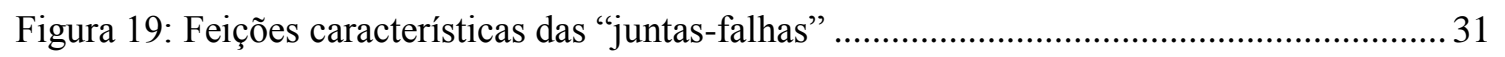

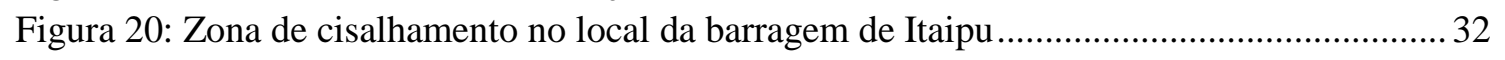

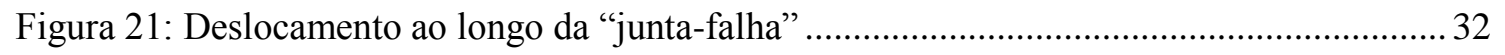

Figura 22: Distribuição espacial das principais feições cisalhadas no local da barragem de

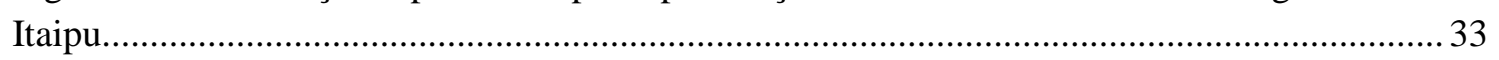

Figura 23: Principais aspectos das fraturas sub-horizontais no local da barragem de Itaipu,

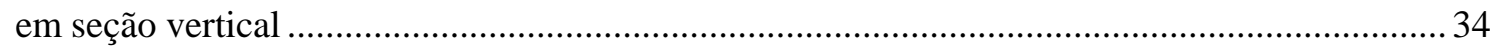

Figura 24: Fluxograma da evolução dos termos aplicados às fraturas sub-horizontais em

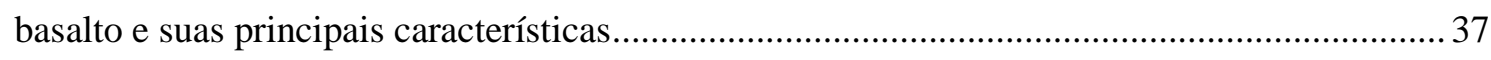

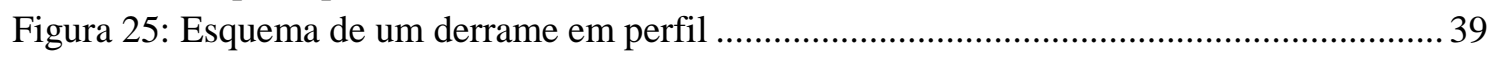

Figura 26: Modelo de gênese das fraturas de grande continuidade lateral em função das

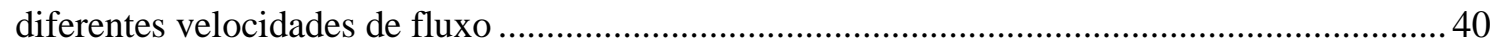

Figura 27: Modelo de formação de "juntas-falhas" de origem primária ...................................... 41

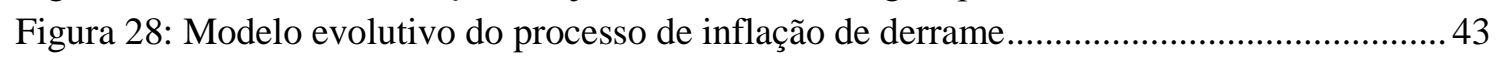

Figura 29: Modelo de desenvolvimento dos níveis colunata e entablamento ................................ 44

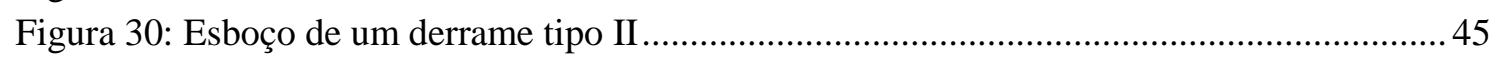

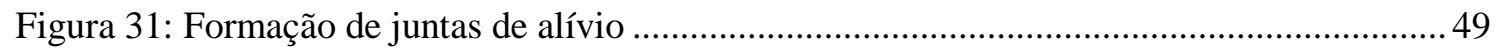

Figura 32: Feições estruturais relacionadas ao alívio de tensões em vales ...................................50

Figura 33: Seção geológica no local da barragem de Itaipu ilustrando a estrutura

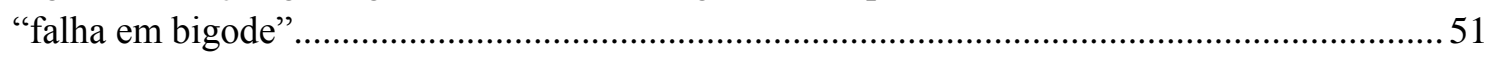

Figura 34: Modelo tectônico transcorrente para a formação das "juntas-falhas".......................... 54

Figura 35: Modelo da gênese de "juntas-falhas" com a atuação de esforços compressivos durante processo erosivo 
Figura 36: Elipsóide de deformação e projeção estereográfica com a identificação de

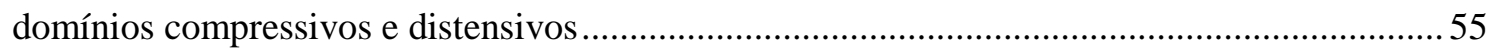

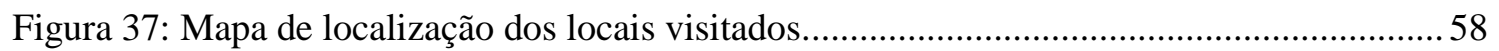

Figura 38: Túnel de prospecção da barragem da Usina Hidrelétrica de

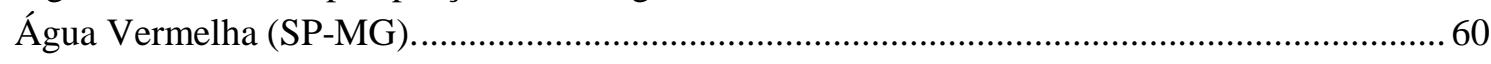

Figura 39: Seção geológica esquemática dos derrames basálticos no local da barragem de

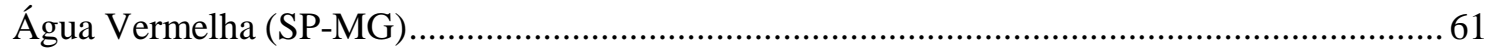

Figura 40: Estereograma com a distribuição polar dos planos das fraturas e rosácea com

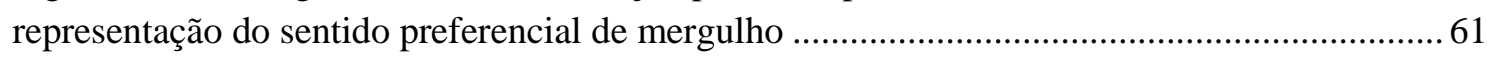

Figura 41: Horizonte fraturado com 10 a $40 \mathrm{~cm}$ de espessura no local da Usina Hidrelétrica

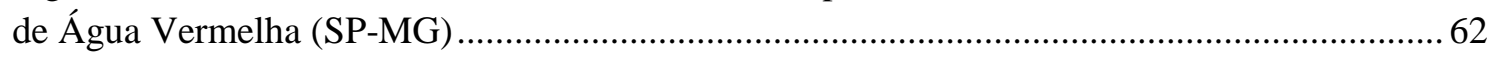

Figura 42: Horizonte fraturado com espessura de quase 2 metros no local da Usina

Hidrelétrica de Água Vermelha (SP-MG).

Figura 43: Fraturas sub-horizontais curviplanares e planares, com espaçamento variando no local da Usina Hidrelétrica de Água Vermelha (SP-MG)

Figura 44: Preenchimento das fraturas de aspecto de brecha no local da Usina Hidrelétrica de Água Vermelha (SP-MG)

Figura 45: Brecha basáltica no local da Usina Hidrelétrica de Água Vermelha (SP-MG) .........6 65

Figura 46: Níveis colunata e entablamento no Município de Laranjeiras do Sul (PR). ............... 67

Figura 47: Horizonte fraturado separado pelos níveis entablamento e colunata, no

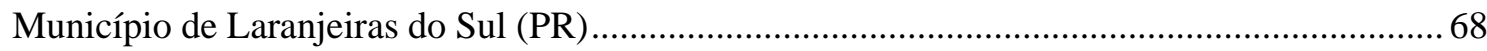

Figura 48: Detalhe do horizonte fraturado no Município de Laranjeiras do Sul (PR) ................6 69

Figura 49: Detalhe do horizonte fraturado no Município de Laranjeiras do Sul (PR) ................. 69

Figura 50: Horizonte fraturado acompanhando a ondulação do derrame no Município de

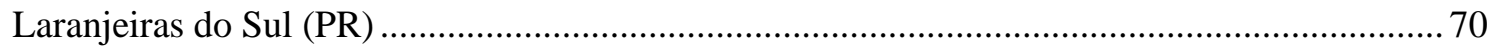

Figura 51: Horizonte fraturado inclinado com encurvamento das fraturas no Município de

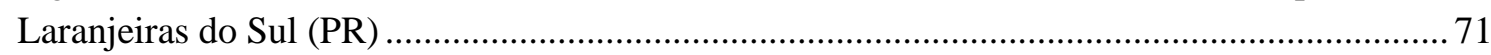

Figura 52: Níveis entablamento e colunata separados por um horizonte fraturado no

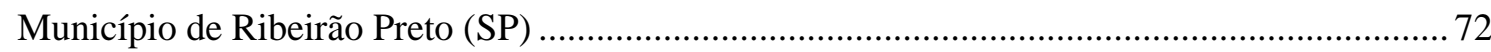

Figura 53: Detalhe do horizonte fraturado no Município de Ribeirão Preto (SP)........................ 74

Figura 54: Estereograma representando a distribuição polar dos planos das fraturas e rosácea com a representação do sentido preferencial de mergulho.

Figura 55: Película milimétrica preenchendo o plano das fraturas no Município de

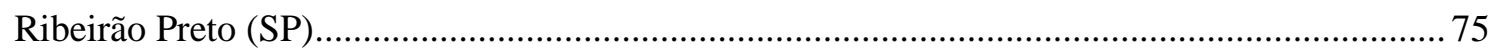

Figura 56: Zona de brecha no Município de Ribeirão Preto (SP) .............................................. 76

Figura 57: Amostra composta por fragmentos de basalto angulosos rodeados por calcita

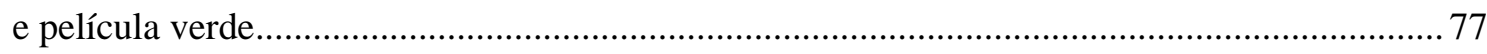

Figura 58: Horizonte fraturado de grande continuidade lateral no Município

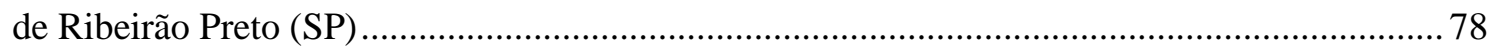

Figura 59: Horizonte fraturado definido por fraturas sub-horizontais no Município

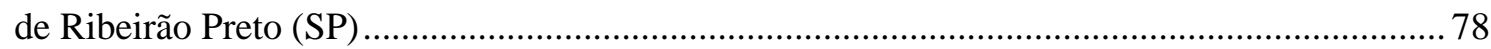

Figura 60: Amostra com película milimétrica de quartzo e calcita ................................................ 79

Figura 61: Fratura sub-horizontal com preenchimento no Município de Ribeirão Preto (SP) .... 79

Figura 62: Horizonte fraturado com fraturas paralelas fechadas pelo preenchimento

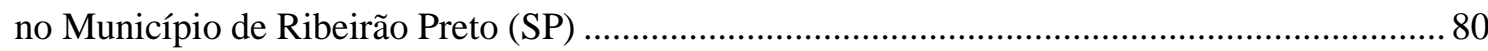

Figura 63: Esquema representativo dos principais tipos de fraturas sub-horizontais.................... 89 
Quadro 1: Síntese de denominações e definições das fraturas sub-horizontais de grande continuidade lateral.

Quadro 2: Hipóteses de gênese e deformação de fraturas sub-horizontais de grande continuidade lateral associadas a eventos tectônicos.

Quadro 3: Síntese dos tipos fraturas sub-horizontais encontradas nos derrames basálticos da Formação Serra Geral.

Tabela 1: Análise mineralógica do material de preenchimento de fraturas sub-horizontais........83 


\section{INTRODUÇÃO}

Derrames basálticos estão sujeitos a uma complexa estruturação interna devido às condições diversas atuantes durante o processo de consolidação da lava (v.g. Goehring \& Morris 2008). As fraturas mais comumente encontradas em derrames basálticos são juntas dispostas em arranjo poliedral definidas como disjunções colunares, geradas durante o resfriamento da lava. Estas juntas definem diferentes zonas estruturais dentro do derrame basáltico, de acordo com a sua regularidade e desenvolvimento. No entanto, em certos derrames pode ocorrer o predomínio das juntas sub-horizontais sobre as verticais (Leinz 1949, Guidicini \& Campos 1968, Souza Jr. 1986).

Os sistemas de fraturas presentes nos derrames basálticos constituem descontinuidades de grande importância como rotas de percolação de fluídos (Kulkarni et al. 2000, Fernandes et al. 2008, 2010a, b), na estabilidade de taludes em rodovias (Pinheiro \& Soares 2004), bem como em obras de engenharia (Weaver \& Bruce 2007). No final da década de 60, por ocasião da construção de grandes hidrelétricas implantadas sob os derrames basálticos da Formação Serra Geral, no sudeste e sul do Brasil, foi constatada a ocorrência de descontinuidades subhorizontais de grande continuidade lateral, de até centenas de metros. Essas estruturas foram inicialmente descritas por Guidicini \& Campos (1968) e denominadas como "juntas-falhas", termo que demonstra claramente a incerteza quanto a origem dessas descontinuidades. Tais estruturas foram intensamente estudadas até o início da década de 90, dada sua importância na construção de grandes barragens no Estado de São Paulo e estados vizinhos. O termo "juntafalha" se consagrou na Geologia de Engenharia, sendo até hoje utilizado por profissionais da área e em livros-textos (e.g. Oliveira \& Brito 1998, Maciel Filho 2008).

A gênese das "juntas-falhas" foi atribuída ao longo dos anos a diferentes processos, os quais consideraram desde a formação de juntas e de falhas em um mesmo evento ou a eventos distintos (Guidicini \& Campos 1968, Guidicini 1979, Björnberg \& Kutner 1983, Souza Jr. \& Campos 1987a, b). Em vista da variedade de feições que foram atribuídas às "juntas-falhas" ao longo dos anos, as características de tais estruturas também são diversas. Neste trabalho, foram reunidas as hipóteses para a gênese das fraturas sub-horizontais, assim como os agentes externos que podem condicionar seu desenvolvimento. Tais processos serão discutidos dentro do quadro de eventos sin, tardi e pós-magmáticos sob os quais as fraturas sub-horizontais estiveram sujeitas. A análise do material que preenche as fraturas, os quais muitas vezes 
expressam estrias de fricção, contribuí para o reconhecimento da idade relativa dos eventos envolvidos. Reunindo os trabalhos disponíveis na literatura, pôde-se identificar os diferentes tipos de fraturas sub-horizontais presentes nos derrames basálticos da Formação Serra Geral, bem como seus possíveis processos geradores.

A Bacia do Paraná encerra extenso, espesso e, portanto, volumoso pacote de lavas basálticas toleíticas relacionadas ao magmatismo Eocretáceo da Formação Serra Geral (Renne et al. 1992, Turner et al. 1994), no qual são reconhecidas numerosas ocorrências de fraturas sub-horizontais de grande continuidade lateral, objeto de várias investigações. Entretanto, grande parte dos resultados dessas investigações repousa principalmente em relatórios internos de empresas de Engenharia, de circulação restrita, com pouca divulgação na literatura aberta nacional (e.g. Guidicini 1979) ou internacional (e.g. Souza Jr. \& Campos 1990). 


\section{META, OBJETIVOS E JUSTIFICATIVA}

Este trabalho tem como meta apresentar uma revisão dos conhecimentos disponíveis sobre a tipologia e mecanismos geradores de fraturas sub-horizontais em basalto, tendo como foco de estudo os derrames da Formação Serra Geral. Para tanto, foram definidos como objetivos principais a elaboração de um quadro dos diferentes tipos de fraturas subhorizontais desenvolvidas em basaltos, a definição de seus mecanismos geradores e uma proposta de classificação atualizada.

O estudo é justificado tendo em vista que o conhecimento dessas feições estruturais praticamente não avançou no Brasil nos últimos vinte anos. Tais estruturas são de grande importância para obras instaladas em substrato basáltico, como pequenas centrais hidrelétricas $(\mathrm{PCH})$, solicitadas como parte do programa de expansão do aproveitamento do potencial energético dos recursos hídricos do país. Adicionalmente, os basaltos da Formação Serra Geral constituem um aquífero fraturado e importante fonte de recursos hídricos para algumas cidades do interior do Estado de São Paulo e também potencial rota de infiltração de poluentes urbanos, industriais e resultantes da atividade agrícola. Dessa forma, os conhecimentos sobre os padrões de fraturas são essenciais nas etapas prévias de pesquisa que influenciarão no planejamento e execução de projetos. Um dos principais problemas que envolve tais estruturas consiste na utilização de termos inadequados até hoje presentes na literatura, que, em parte, deve-se a complexidade de sua origem. 


\section{MATERIAIS E MÉTODOS}

Para a elaboração do presente trabalho foi realizada uma extensa pesquisa bibliográfica, trabalho de reconhecimento de campo, análises de laboratório e integração dos resultados.

Foi realizado inicialmente um amplo levantamento bibliográfico que consistiu na etapa mais importante do trabalho, em vista dos objetivos propostos, com a leitura da bibliografia disponível sobre as fraturas sub-horizontais de grande continuidade lateral e estruturas designadas de "juntas-falhas”, presentes nos derrames da Formação Serra Geral. Este material encontra-se disperso, com publicações entre as décadas de 60 e 90, em simpósios, seminários e congressos nacionais e internacionais específicos das áreas de Geotecnia, Geologia de Engenharia e construções de barragens. Foi realizado também o levantamento bibliográfico sobre os derrames basálticos da Formação Serra Geral, na Bacia do Paraná, e seu arcabouço tectônico, bem como o levantamento das principais províncias basálticas continentais do mundo, com o intuito de encontrar referências sobre estruturas correlatas fora do Brasil.

O reconhecimento de campo compreendeu a investigação de três áreas de afloramentos, nas regiões dos municípios de Laranjeiras do Sul (PR), Ribeirão Preto (SP) e Ouroeste (SP). Nesta etapa, foi feito o reconhecimento do estilo e levantamento de dados estruturais de fraturas sub-horizontais presentes em derrames basálticos. Foi realizada a coleta de amostras e materiais de preenchimento das fraturas para posterior análise.

A análise em laboratório foi realizada em amostras do material de preenchimento das fraturas no Laboratório de Difração de Raios X do Instituto de Geociências da Universidade de São Paulo. A preparação das amostras consistiu na moagem do material em gral de ágata e confecção de lâminas delgadas. A identificação mineralógica de rotina por difração de raios X, empregando-se difratômetro Siemens modelo D-5000, foi realizada em nove amostras.

A etapa final compreendeu a análise e integração dos dados obtidos e redação da monografia. 


\section{CONTEXTO GEOLÓGICO}

\subsection{A Província Basáltica Paraná-Etendeka e a Formação Serra Geral}

A Província Basáltica Paraná-Etendeka é um dos principais exemplos de vulcanismo associado à ruptura de placas litosféricas, neste caso, vinculada à fragmentação do Gondwana, com a separação da America do Sul e África durante o Cretáceo Inferior. Considerando-se a natureza das rochas, sua extensão, espessura, e consequentemente o volume de lavas, o magmatismo da Formação Serra Geral é característico de províncias basálticas continentais. As províncias basálticas continentais constituem as maiores áreas de extravasamento de lava da história da Terra em áreas de crosta continental. Estão associadas a anomalias localizadas do manto superior, capazes de produzir altas taxas de fusão nos estágios iniciais da atividade vulcânica, com grande escala e tempo de duração da atividade vulcânica (Jerram \& Widdowson 2005). As principais províncias basálticas do mundo estão representadas na figura 1.

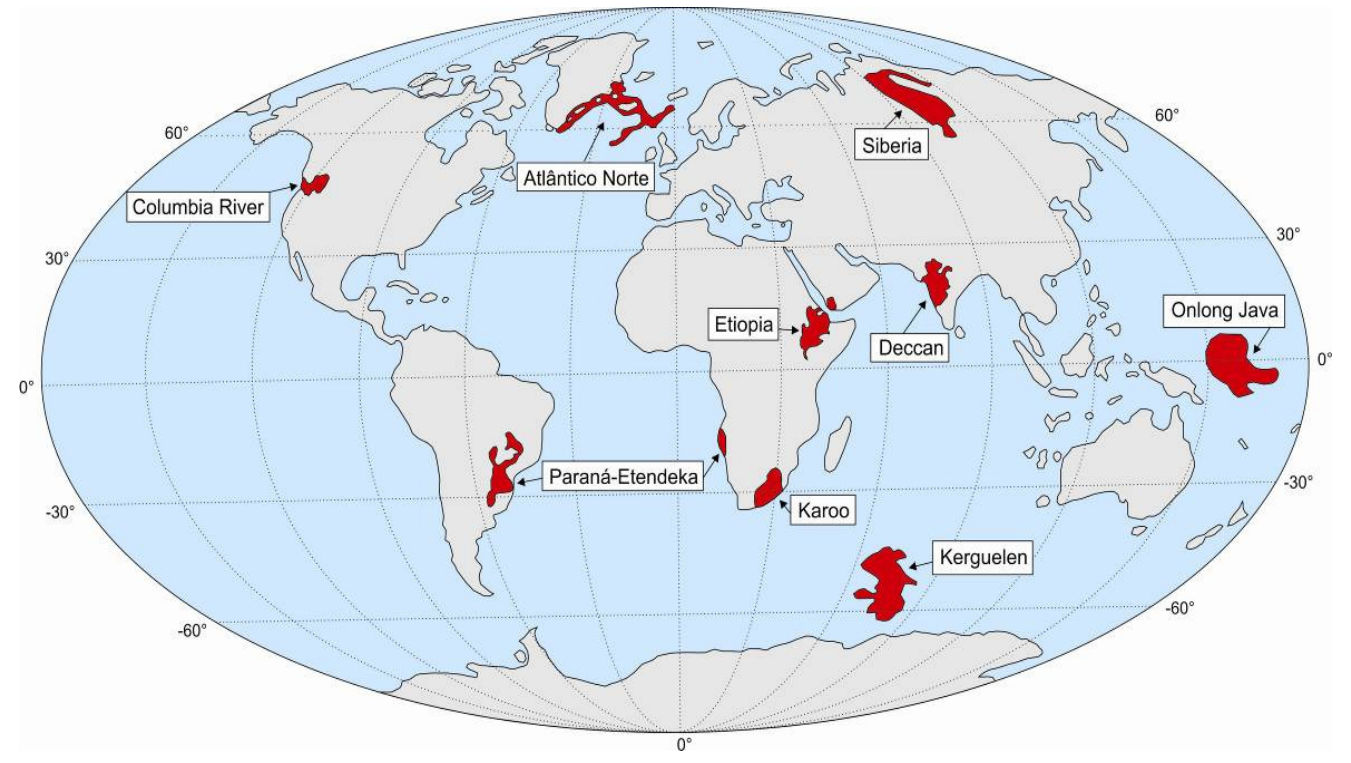

Figura 1: Localização das principais províncias basálticas. Adaptado de Jerram \& Widdowson (2005). 
A Província Basáltica Paraná-Etendeka é uma das maiores manifestações de basaltos continentais do mundo, com uma extensão de aproximadamente $1.300 .000 \mathrm{~km}^{2}$, dos quais 1.200.000 km² estão localizados na América do Sul, abrangendo o Brasil, Paraguai, Argentina e Uruguai, com um volume estimado em $800.000 \mathrm{~km}^{3}$ (Melfi et al. 1988, Almeida et al. 2000). Dados mais atualizados indicam que a extensão das rochas vulcânicas da Bacia do Paraná seria, mais precisamente, de $917.000 \mathrm{~km}^{2}\left( \pm 15.000 \mathrm{~km}^{2}\right)$, com um volume estimado em $600.000 \mathrm{~km}^{3}$, somando-se os derrames e os corpos intrusivos do tipo sill (Frank et al. 2009).

Os derrames basálticos da Província Basáltica Paraná-Etendeka, designados no Brasil de Formação Serra Geral, marcam o final da deposição sedimentar na Bacia do Paraná. Esta bacia constitui uma sinéclise intracratônica, desenvolvida a partir do Neo-Ordoviciano (Zalán et al. 1990, Milani 2004), preenchida por rochas sedimentares e vulcânicas na forma de derrames, com diques e sills associados. A Bacia do Paraná está localizada na porção centroleste do continente sul-americano, apresenta formato alongado, de direção geral norte-sul, e seu pacote vulcano-sedimentar atinge espessura total superior a 6.000 metros (figura 2). A origem da bacia se deu após a estabilização do Paleocontinente Gondwana, e seu registro sedimentar se estende desde o Neo-Ordoviciano até o Eocretáceo. A evolução da bacia é subdividida em quatro ciclos principais de subsidência (Milani 1997), definidos como supersequências: Rio Ivaí (ordoviciana - siluriana), Paraná (devoniana), Gondwana I (carbonífera - eotriássica) e Gondwana II (mesotriássica a neotriássica). As rochas vulcânicas da Formação Serra Geral, juntamente com os arenitos eólicos da Formação Botucatu, correspondem a supersequência Gondwana III (eocretácea). Sobre a área geográfica da Bacia do Paraná assenta-se a sequência neocretácea da Bacia Bauru (Fernandes \& Coimbra 1996). O vulcanismo na Bacia do Paraná se manifestou com caráter fissural, produzindo 800.000 $\mathrm{km}^{3}$ de lavas, sendo 97,5\% lavas basálticas e o restante lavas ácidas (Nardy et al. 2002). Datações pelo método ${ }^{40} \mathrm{Ar}-{ }^{39} \mathrm{Ar}$ indicaram idades entre 138 a 125 Ma para a atividade magmática na bacia (Renne et al. 1992, Turner et al. 1994). 


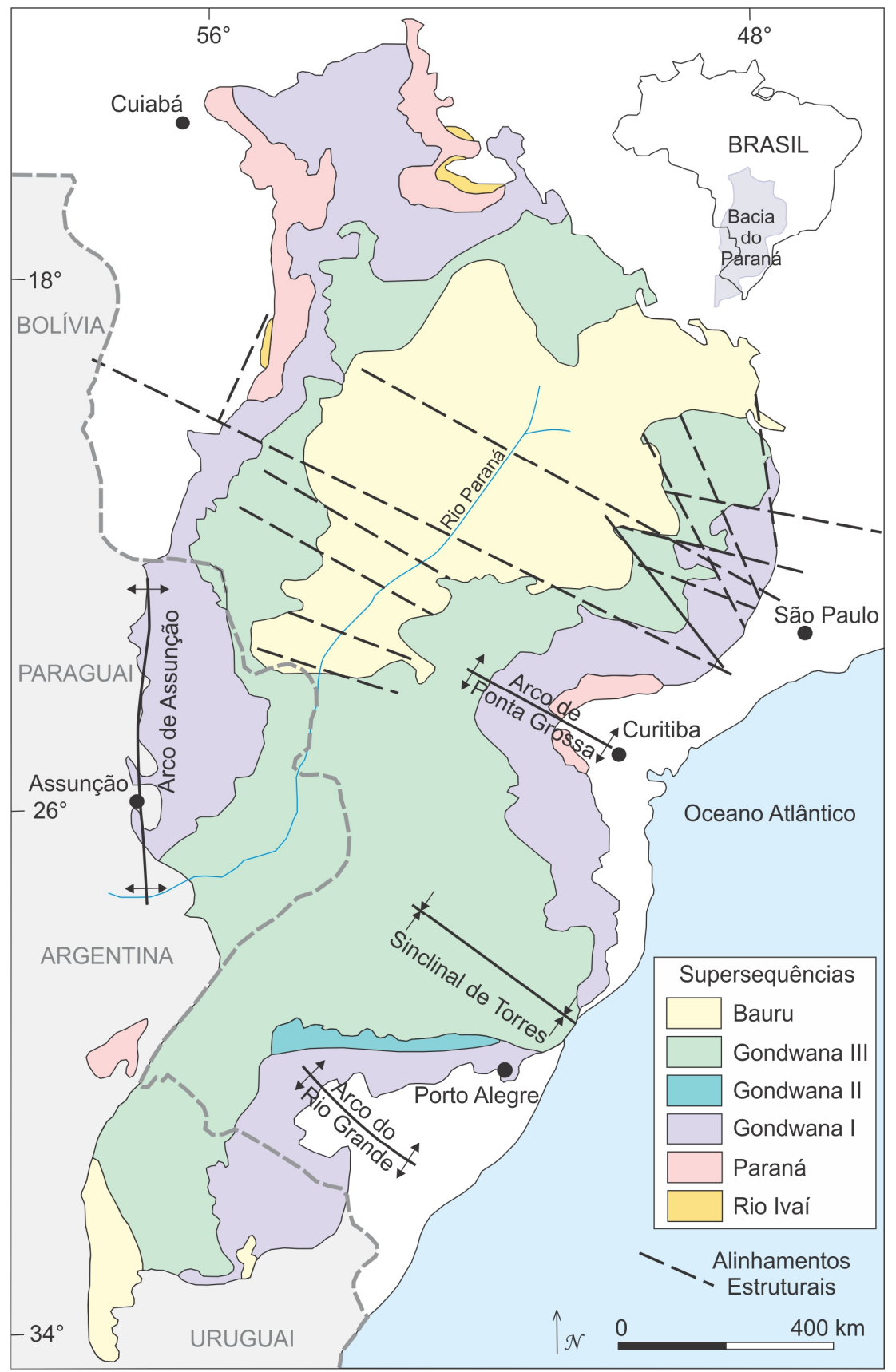

Figura 2: Mapa geológico simplificado da Bacia do Paraná com os principais alinhamentos estruturais. Compilado de Fulfaro \& Perinotto (1994), Milani \& Ramos (1998) e Riccomini (1997a) por Sallun et al. (2007).

No Mesozóico-Cenozóico a Bacia do Paraná passou a sofrer influência dos eventos tectônicos ligados à ruptura do Gondwana, com a abertura do paleocontinente e a movimentação da Placa Sul Americana. A ruptura continental foi precedida por um intenso magmatismo toleítico no Eocretáceo que originou as rochas magmáticas da Formação Serra Geral (Marques \& Ernesto 2004). A configuração estrutural da Bacia do Paraná é 
caracterizada pela presença de extensos alinhamentos estruturais, em parte resultantes de reativação de estruturas preexistentes no embasamento (figura 2). Esses alinhamentos estruturais correspondem a concentrações de falhas, altos estruturais, diques e sills (Riccomini 1995, Rostirolla 2000, Artur \& Soares 2002). No Neocretáceo ocorreram importantes atividades tectônicas relacionadas a manifestações alcalinas, que promoveram deslocamentos ao longo de alinhamentos estruturais e influenciaram na sedimentação da Bacia Bauru (Riccomini 1995, Fernandes \& Coimbra 1996). No Cenozóico, o tectonismo deformador dessa bacia é registrado por estruturas rúpteis resultantes de regimes transcorrentes, correlacionados a importantes alinhamentos estruturais, com provável atividade neotectônica (Riccomini 1997a, b).

\subsection{Morfologia de derrames basálticos}

Os derrames basálticos apresentam padrões de empilhamento característicos, relacionados ao estilo, volume extravasado, duração e periodicidade do vulcanismo, que acarretam diferentes relações geométricas internas e externas nos derrames (Jerram \& Widdowson 2005). As províncias basálticas continentais apresentam frequentemente padrão de fluxo tabular, com extensão lateral de até centenas de quilômetros e dezenas de metros de espessura. Os diferentes estilos de fluxos basálticos identificados nas províncias basálticas continentais estariam relacionados à taxa de erupção. Dessa forma, altas taxas de erupção gerariam derrames de fluxos simples, enquanto que taxas menores gerariam derrames do tipo fluxo composto (Walker 1971). Os derrames compostos são formados por vários lobos com espessuras e dimensões semelhantes, enquanto os derrames simples correspondem a uma única unidade de resfriamento, sendo que os dois tipos geralmente são encontrados na mesma província basáltica (Bondre et al. 2004a).

A Formação Serra Geral é composta por sucessões de derrames que se distribuem por grande extensão da bacia. Individualmente os derrames apresentam espessuras variáveis, geralmente entre 10 e 80 metros (Marques \& Ernesto 2004), atingindo algumas vezes até 100 metros de espessura (Leinz et al. 1966). A sucessão de derrames da Formação Serra Geral pode ser considerada como típico derrame tabular (Jerram \& Widdowson 2005), com 
espessura máxima de 1.700 metros e composta predominantemente por basaltos de afinidade toleítica (Leinz et al. 1966, Melfi et al.1988).

Nos seus aspectos morfológicos, os derrames basálticos da Formação Serra Geral, foram detalhadamente estudados por Guidicini \& Campos (1968) e Gomes (1996), mostrando uma configuração semelhante aos derrames de fluxo simples descritos por Bondre et al. (2004a, b) na Província Basáltica de Deccan. Os derrames de fluxo simples, também denominados de derrames maciços (Waichel 2006) ou tabulares (Arioli et al. 2008), ocorrem na Formação Serra Geral de forma isolada entre espessas sucessões de derrames lobados, com intercalações sedimentares e vulcanoclásticas (Arioli et al. 2008). Waichel (2006) identificou no oeste do Estado do Paraná derrames do tipo pahoehoe inflados de fluxo composto em associação com derrames de fluxo simples.

O lençol de lava é dividido em três porções morfológica principais, relacionadas diretamente à alternância textural dos basaltos: basal, central e superficial.

A porção basal do derrame é evidenciada por maior incidência de material vítreo e caracterizada por basalto vesicular e/ou amigdaloidal, com preenchimento por minerais secundários. As vesículas representam horizontes de desgasificação devido ao rápido resfriamento da lava em contato com a superfície de fluxo (Guidicini \& Campos 1968, Gomes 1996). Essa faixa vítrea passa gradativamente em direção ao topo para um basalto microcristalino, rico em diáclases horizontais (Leinz 1949) (figura 3).

A porção central do derrame é composta por basalto compacto com grau de cristalinidade variável e granulação afanítica à fanerítica grossa, com textura afírica a porfirítica. Quando o derrame é relativamente espesso, essa porção ocupa cerca de $2 / 3$ da sua espessura total (Guidicini \& Campos 1968), geralmente com 40 metros de espessura, possuindo predominantemente diáclases verticais (Leinz 1949) (figura 3). No topo do núcleo dos derrames pode ocorrer um nível macrovesícular com geodos de tamanho variado (Gomes 1996, Arioli et al. 2008).

A porção superior do derrame possui geralmente 5 a 10 metros de espessura, com predomínio de diáclases horizontais (Leinz 1949, Leinz et al. 1966) (figura 4.2.1). Esta zona é caracterizada por ser rica em vesículas ou amídalas preenchidas por zeólitas, quartzo e calcedônia, que chegam a 30-40\% do volume da rocha (Gomes 1996, Arioli et al. 2008). 
Constitui um horizonte vesicular que corresponde à faixa de desgasificação, neste caso decorrente do rápido resfriamento da lava em contato com a atmosfera (Guidicini \& Campos 1968, Gomes 1996).

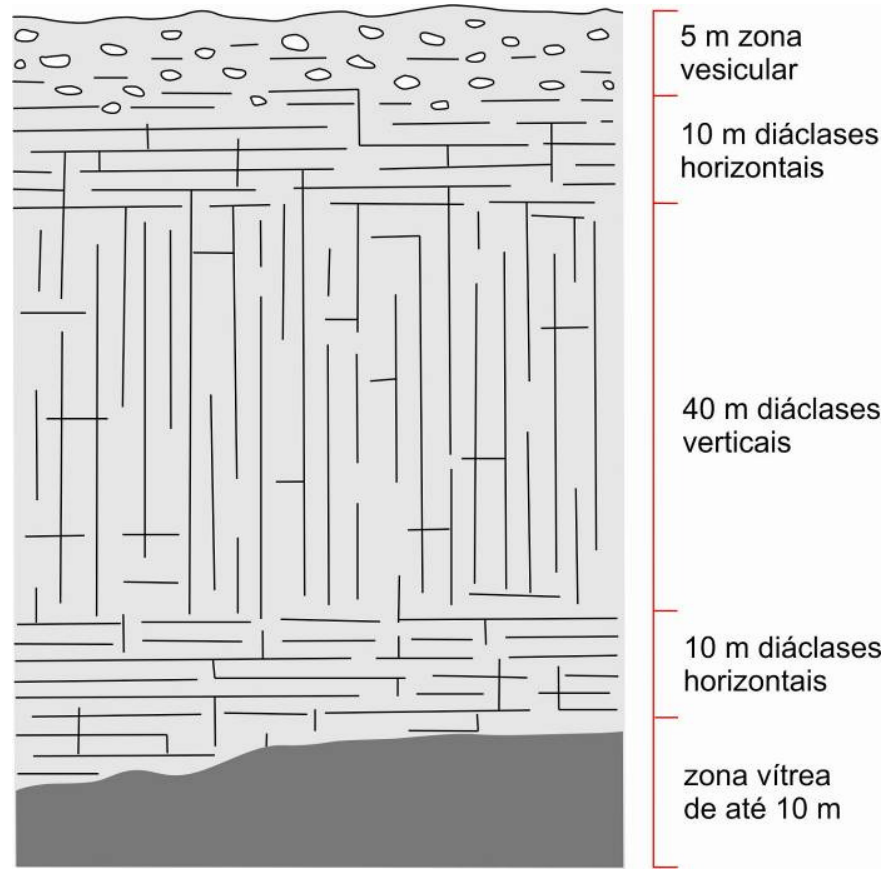

Figura 3: Modelo esquemático de um derrame basáltico em perfil, elaborado por Leinz (1949).

Entre os sucessivos derrames normalmente ocorrem brechas vulcânicas, constituídas por fragmentos angulosos de basalto vesicular cimentados por matriz sedimentar arenosiltosa, carbonática (calcita) ou basáltica (lavas aglomeráticas), associadas à superfície do derrame; e sedimentos interpostos, constituídos de areia fina, silte e argila, frequentemente com cimento quartzoso, e podem se manifestar também como intrusões arenosas na forma de pequenos diques e veios no corpo do derrame (Guidicini \& Campos 1968).

O resfriamento dos derrames basálticos se manifesta a partir das extremidades para o centro do derrame e durante esse processo são geradas juntas de contração por resfriamento. As juntas de resfriamento são normalmente sub-verticais e formam disjunções colunares em forma de prismas alongados, que se desenvolvem preferencialmente em um sistema hexagonal (Spry 1962). Ao longo das disjunções colunares podem ocorrer juntas transversais, que interceptam as colunas e correspondem a juntas planares de pequena extensão (Lyle 2005). A distância entre as juntas transversais normalmente resulta ao longo das colunas 
feições em forma de discos comparados a queijos holandeses (Dutch cheeses, MacDonald 1967) (figura 4).

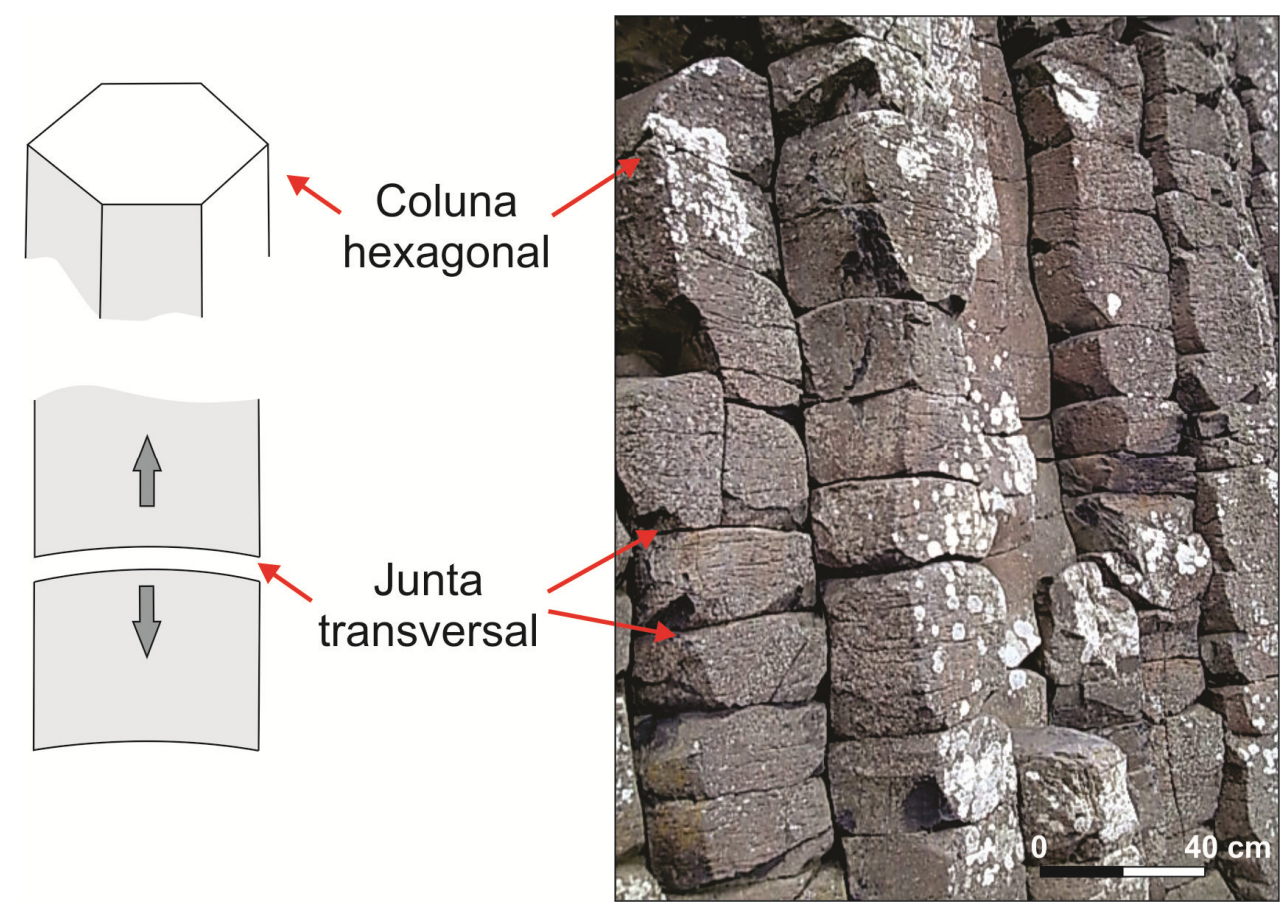

Figura 4: A figura a esquerda representa uma seção em perfil de uma coluna vertical dividida horizontalmente por juntas transversais (Lyle 2005). A figura à direita corresponde a um exemplo de juntas transversais ao longo de disjunções colunares em derrames basálticos (Giant's Causeway, Irlanda do Norte).

A complexa configuração das disjunções colunares em maciços basálticos e seu processo gerador foram detalhadamente estudados por Tomkeieff (1940) e Spry (1962) em diferentes localidades. Tomkeieff (1940) (apud Spry 1962) sugeriu os termos colunata (colonnade) e entablamento (entablature), emprestados da arquitetura clássica (colonnato, do italiano e entablement, do francês) para designar o padrão de fraturas colunares observado no maciço basáltico de Giant's Causeway na Irlanda do Norte. O padrão de fraturas se manifesta principalmente em derrames de maior espessura, dividindo-o em níveis estruturais bem definidos (Spry 1962, Long \& Wood 1986).

A colunata ocorre tipicamente na parte superior e inferior do derrame. O nível de colunata inferior consiste de colunas relativamente bem formadas, perpendiculares à base do 
derrame e atinge largura de aproximadamente 30 centímetros a 2 metros (figura 5). O nível de colunata superior nem sempre está presente.

O entablamento é o nível intermediário entre a colunata superior e inferior, normalmente ocupando 60 a $70 \%$ da espessura do derrame. Este nível é composto por delgadas disjunções colunares encurvadas e irregulares, com espessura de 20 a 50 centímetros. As colunas podem formar um padrão radial ou desviar da orientação perpendicular à base do derrame (figura 5). Petrograficamente, o entablamento possui maior mesóstase vítrea (cerca de 60\%) e menor granulação que a zona colunata. Este nível é considerado o resultado do resfriamento acelerado da parte superior do derrame, devido ao recobrimento da sua superfície por água (Long \& Wood 1986).

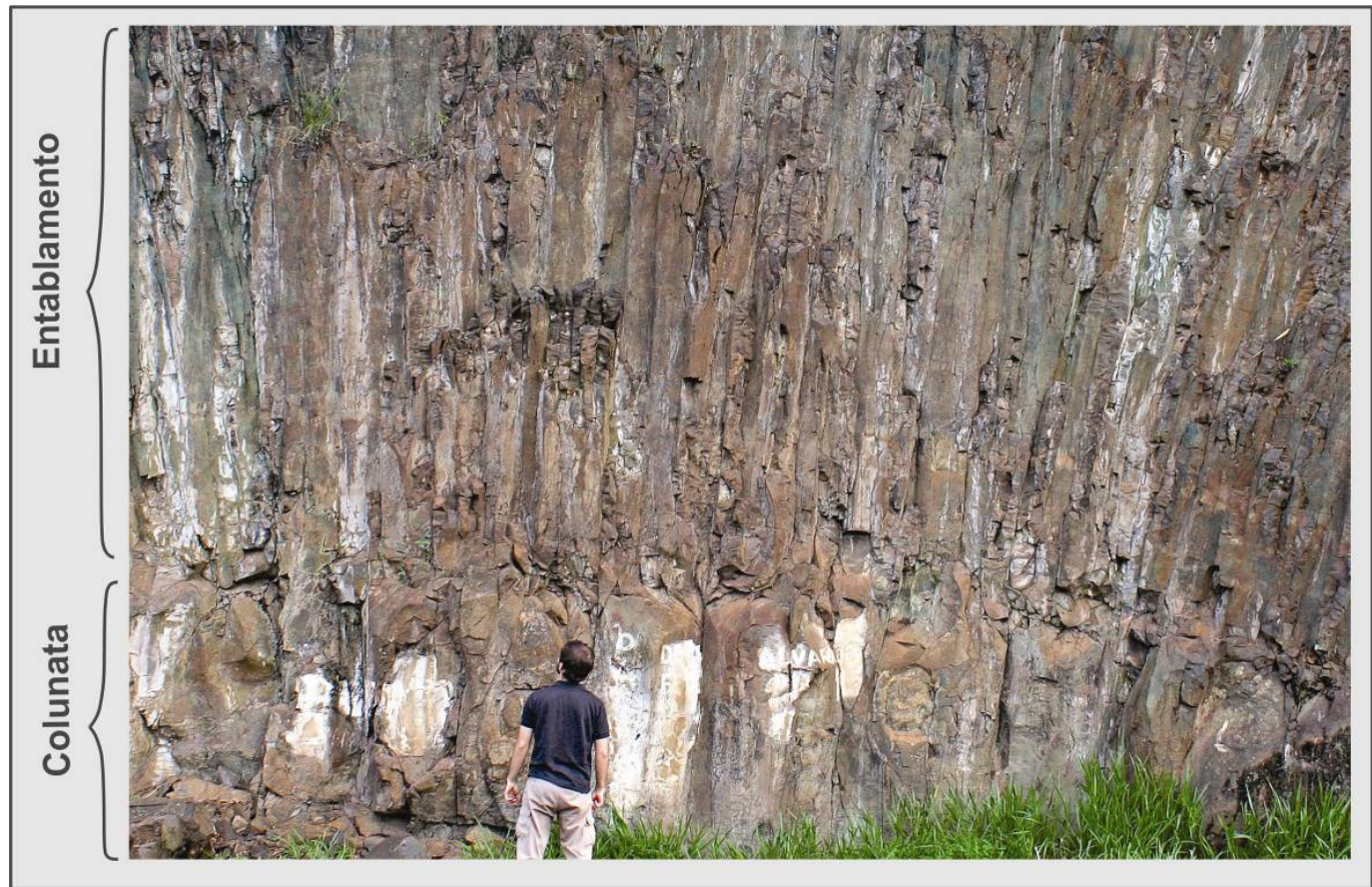

Figura 5: Padrão de fraturas em derrame basáltico da Formação Serra Geral, próximo ao município de Laranjeiras do Sul (PR), subdividido em dois níveis: entablamento (colunas irregulares, com $25 \mathrm{~cm}$ de largura em média) e colunata (colunas bem formadas com largura de $60 \mathrm{~cm}$ em média).

De acordo com características estruturais internas, os derrames basálticos podem ser subdivididos em três tipos, definidos por Long \& Wood (1986). Os derrames do tipo I são relativamente pouco espessos (10 a 30 metros), consistem inteiramente de juntas colunares irregulares e não apresentam um nível de entablamento distinto (figura 6). Os derrames tipo II 
e III são em geral bastante espessos (30 a 80 metros), apresentam o clássico padrão de colunata e entablamento geralmente bem desenvolvidos. Os derrames tipo II exibem na porção central uma alternância de mais de uma zona de entablamento e colunata, conferindo ao derrame um aspecto acamadado (multi-tiered) (Long \& Wood 1986). Já os derrames tipo III apresentam apenas um nível de entablamento e um de colunata inferior, geralmente com uma diferença marcante na abundância de fraturas, tamanho das colunas e características texturais entre as duas zonas.

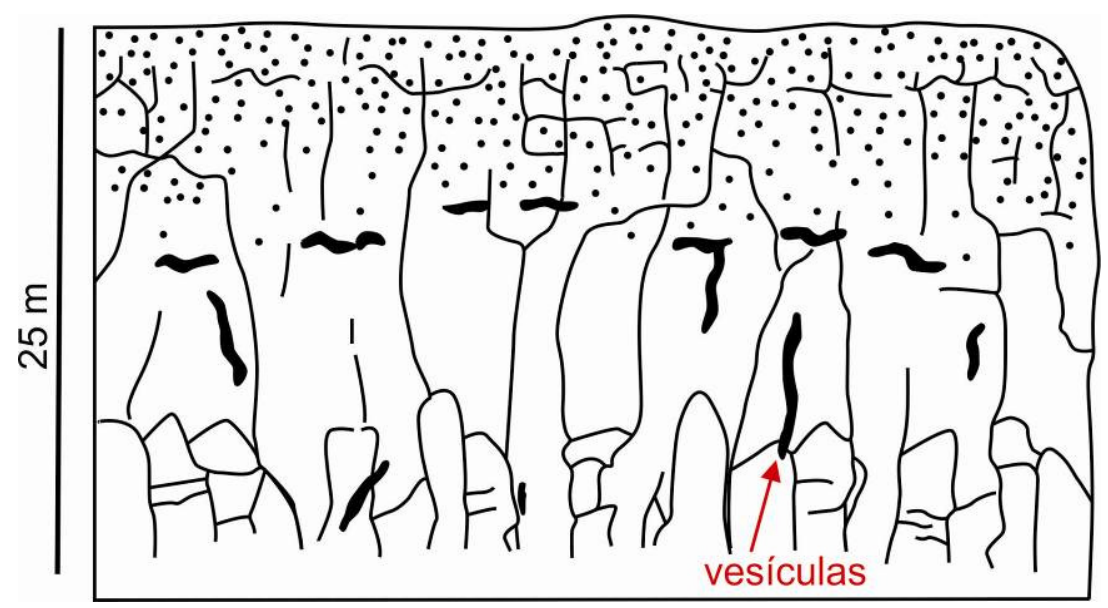

Figura 6: Estrutura interna de derrame tipo I, com juntas verticais irregulares e vesículas em cilindros e lentes. Adaptado de Long \& Wood (1986).

Os derrames basálticos da Formação Serra Geral não apresentam regularmente a compartimentação tripla do padrão de disjunções colunares sugerida por Tomkeieff (1940) e Spry (1962). O que se observa é um núcleo nitidamente subdividido em dois compartimentos, colunata (inferior) e entablamento (superior), correspondentes ao derrame tipo III de Long \& Wood (1986), ou simplesmente constituído por disjunções verticais irregulares, nas quais prevalece na maioria das vezes juntas horizontais próximas às zonas periféricas dos derrames, correspondente ao derrame tipo I (Souza Jr. 1986, Gomes 1996, Arioli et al. 2008). 


\section{DEFORMAÇÃO RÚPTIL E GERAÇÃO DE FRATURAS}

Neste trabalho, será apresentada uma revisão dos conhecimentos disponíveis sobre a tipologia e mecanismos geradores de fraturas sub-horizontais em derrames basálticos da Formação Serra Geral. Devido à importância dos conceitos básicos de geologia estrutural para a compreensão e designação apropriada das estruturas em foco neste trabalho, serão apresentados a seguir os processos fundamentais de deformação rúptil e geração de fraturas.

Segundo a definição de fraturas, tais estruturas compreendem superfícies de ruptura onde a rocha perdeu sua coesão (Ramsay \& Huber 1987, Marshak \& Mitra 1988). Elas ocorrem de forma generalizada na crosta superior sob condições de baixa temperatura e pressão (entre 0 a $300^{\circ} \mathrm{C}$; 0 a $4 \mathrm{~Kb}$ ). São encontradas em sedimentos, inconsolidados e consolidados (litificados), rochas ígneas e metamórficas (Ramsay \& Huber 1987). A geração das fraturas pode ocorrer por deformações resultantes de processos orogênicos e epirogênicos e pela contração resultante do resfriamento da rocha ou dessecação (Price \& Cosgrove 1990). As fraturas, de modo geral, correspondem às estruturas conhecidas como juntas e falhas (Ramsay \& Huber 1987, Marshak \& Mitra 1988, Price \& Cosgrove 1990, Zhao \& Johnson 1992, Angelier 1994, Dunne \& Hancock 1994).

As fraturas se formam mediante três modos de ruptura (Marshak \& Mitra 1988, Pollard \& Aydin 1988) (figura 7). No modo I, as fraturas se formam pela abertura dos planos de ruptura e sua propagação se dá por esforço distensivo, perpendicular ao plano da fratura. As fraturas formadas por esse processo correspondem a fraturas de distensão. Nos modos II e III, a propagação da fratura se dá pelo cisalhamento paralelo ao plano de ruptura, com deslocamento perpendicular (modo II) ou paralelo (modo III) à frente de propagação da fratura, respectivamente. As estruturas formadas por esses processos correspondem a fraturas de cisalhamento. 


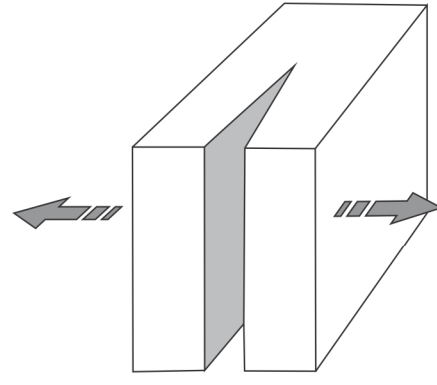

a) Modo I

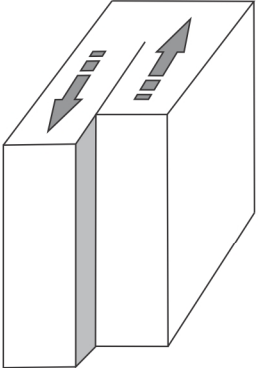

b) Modo II

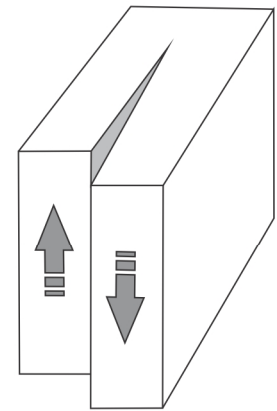

c) Modo III

Figura 7: Bloco diagrama representando os modos de propagação das fraturas por distensão (a) e por cisalhamento com deslocamento perpendicular (b) ou paralelo (c) à frente de propagação da ruptura. Adaptado de Marshak \& Mitra (1988).

Pelos fundamentos de deformação de maciços rochosos, define-se a deformação coaxial (cisalhamento puro) aquela que envolve apenas a translação da massa rochosa, e a deformação não-coaxial (cisalhamento simples), que envolve a rotação da massa rochosa (Hasui \& Mioto 1992). Dessa forma, dentro dos parâmetros de comportamento rúpteis, a deformação coaxial produz fraturas de cisalhamento, que apresentam pares conjugados, simétricos à fratura de distensão $(\mathrm{T})$ e, consequentemente, ao esforço principal maior $(\sigma 1)$, formando um ângulos da ordem de $30^{\circ}$ (figura 8). Já a deformação não-coaxial produz as descontinuidades cisalhantes conjugadas do modelo binário de Riedel (figura 9), em que são geradas fraturas de distensão $(\mathrm{T})$, paralelas à $\sigma 1$, com ângulo de $45^{\circ}$ com a direção do binário, e fraturas de cisalhamento sintéticas e antitéticas, que apresentam relações angulares dependentes do ângulo de atrito interno e movimentos coerentes com o sentido do binário.

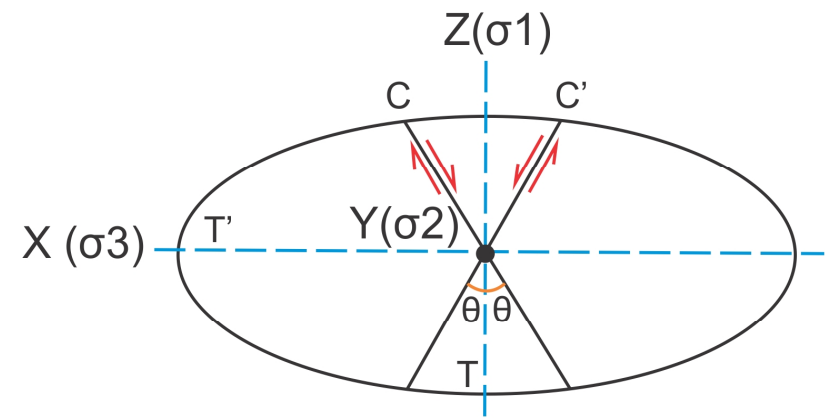

(a)

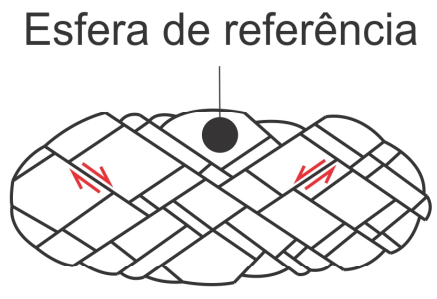

(b)

Figura 8: Descontinuidades de deformação coaxial: a) fraturas de cisalhamento em pares conjugados (C e C'), formando um ângulo $\theta$ (da ordem de $30^{\circ}$ ) com a direção de esforço principal máximo $(\sigma 1)$, e fratura de distensão ( $\mathrm{T}$ e $\mathrm{T}$ ', esta última pode não ocorrer); b) deformação do maciço decorrente do desenvolvimento de C e C' (extraído de Hasui \& Mioto 1992). 


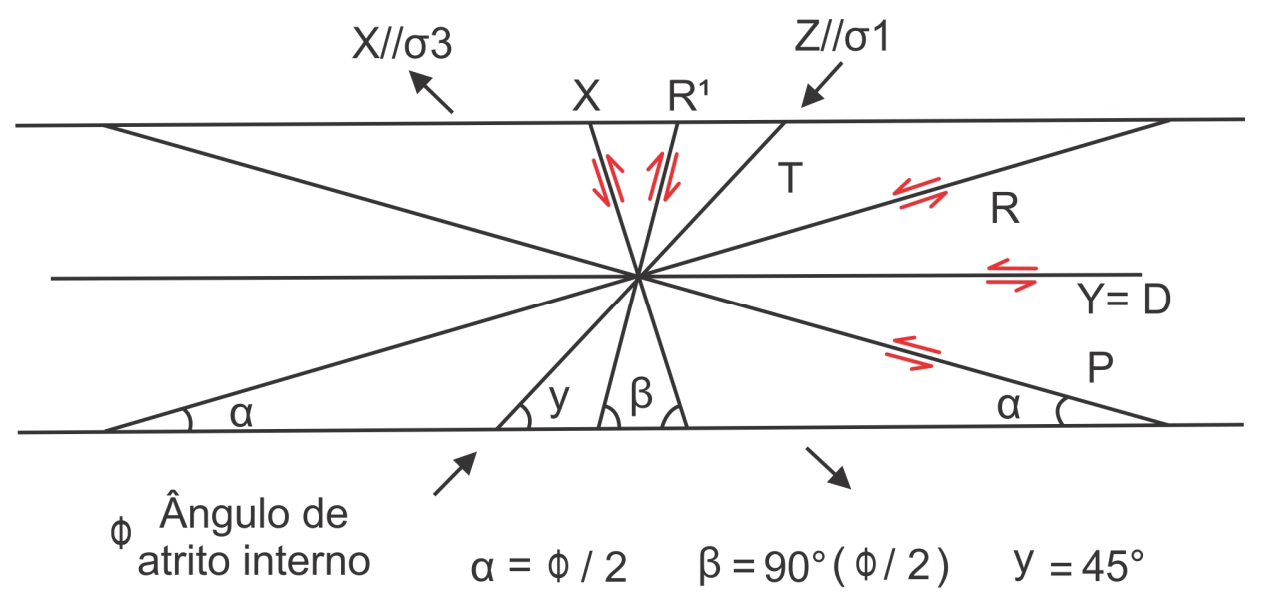

Figura 9: Descontinuidades de deformação não coaxial pelo modelo binário de Riedel: R e R', fraturas de cisalhamento conjugadas de Riedel; T, fratura de distensão; P,Y, X, fraturas de cisalhamento; $\sigma 1$ e $\sigma 3$ eixos de esforços principais máximo e mínimo, respectivamente (adaptado de Dunne \& Hancock 1994).

O principal critério de ruptura conhecido e aplicado é o de Mohr - Coulomb, que representa as condições de esforços sob as quais se dá o fraturamento na rocha (figura 5.4). Através da envoltória de ruptura pode-se descrever a condição de tensão no momento em que a fratura é formada. Segundo Price \& Cosgrove (1990), as fraturas de distensão são formadas perpendicularmente à direção de esforço principal mínimo $(\sigma 3)$, pelo modo I de propagação de fraturas (figura 10 a). As fraturas conjugadas podem ser caracterizadas como fraturas híbridas (figura $10 \mathrm{c}$ ) ou fraturas de cisalhamento (figura 10 b). As fraturas híbridas são formadas pelos modos I, II ou III de propagação de fraturas, ocorrendo distensão e cisalhamento simultaneamente, e apresentam ângulo $2 \theta$ entre as fraturas conjugadas de $1^{\circ} \mathrm{a}$ $59^{\circ}$. As fraturas de cisalhamento são formadas pelos modos II e III de propagação de fraturas e apresentam ângulo $2 \theta$ entre as fraturas conjugadas igual a $60^{\circ}$. A orientação dos eixos de esforços principais pode ser inferido através das fraturas conjugadas, isso porque a atitude da

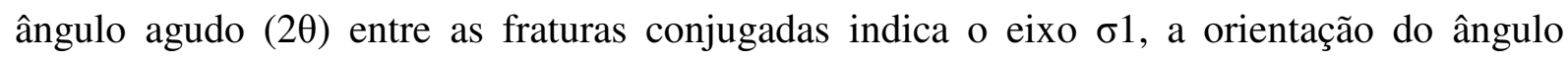
obtuso indica o eixo $\sigma 3$, e a atitude da direção da intersecção entre as fraturas indica o eixo $\sigma 2$. 


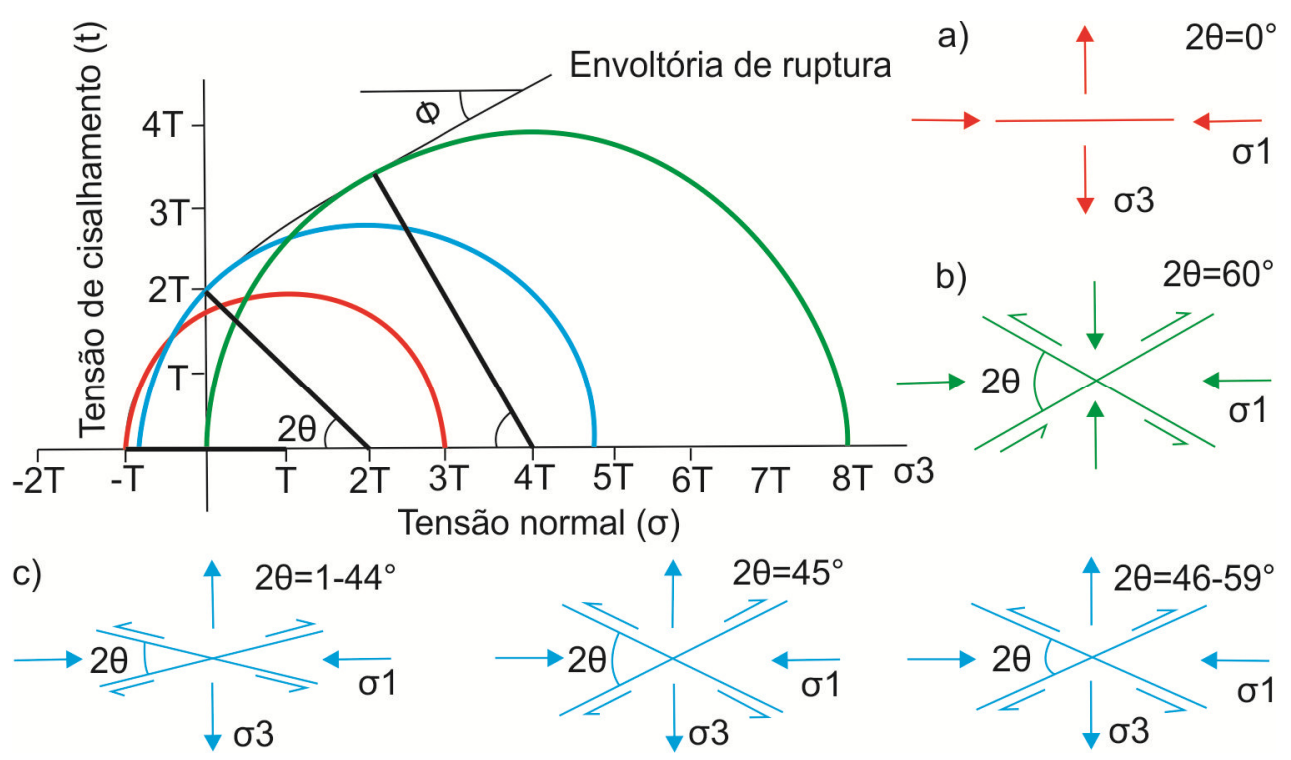

Figura 10: Condições de tensão durante a formação de fraturas em rochas intactas. Diagrama de tensões de Coulomb - Mohr composto pela envoltória de ruptura, onde $\Phi$ corresponde ao ângulo de atrito interno, e pelos círculos de Mohr indicados com cores distintas, representativas das diferentes condições de esforços: a) representação da fratura de distensão correspondente ao círculo de Mohr vermelho $((\sigma 1-\sigma 3) \leq 4 \mathrm{~T})$; b) representação da fratura de cisalhamento correspondente ao círculo de Mohr verde $((\sigma 1-\sigma 3) \geq 8 \mathrm{~T})$; c) representações da fratura híbrida correspondente ao círculo de Mohr azul $(4 \mathrm{~T}<(\sigma 1-\sigma 3)<8 \mathrm{~T})$. Adaptado de Dunne \& Hancock (1994).

De acordo com Cosgrove (1998), as fraturas de distensão $((\sigma 1-\sigma 3) \leq 4 \mathrm{~T})$ seguirão um padrão de feições de acordo com a diferença de magnitude entre $\sigma 1$ e $\sigma 3$ (figura 5.5). Dessa forma, quando $\sigma 3$ é muito inferior a $\sigma 1$ (figura 11, círculo i) as fraturas apresentam uma única orientação, perpendiculares a $\sigma 3$. Conforme $\sigma 3$ e $\sigma 1$ apresentam magnitudes cada vez mais próximas as fraturas adquirem formas truncadas em lentes (figura 11, círculos ii e iii), e quando $\sigma 3$ e $\sigma 1$ apresentam a mesma magnitude (figura 11, círculo iv) as fraturas apresentam um padrão aleatório (brechação). 


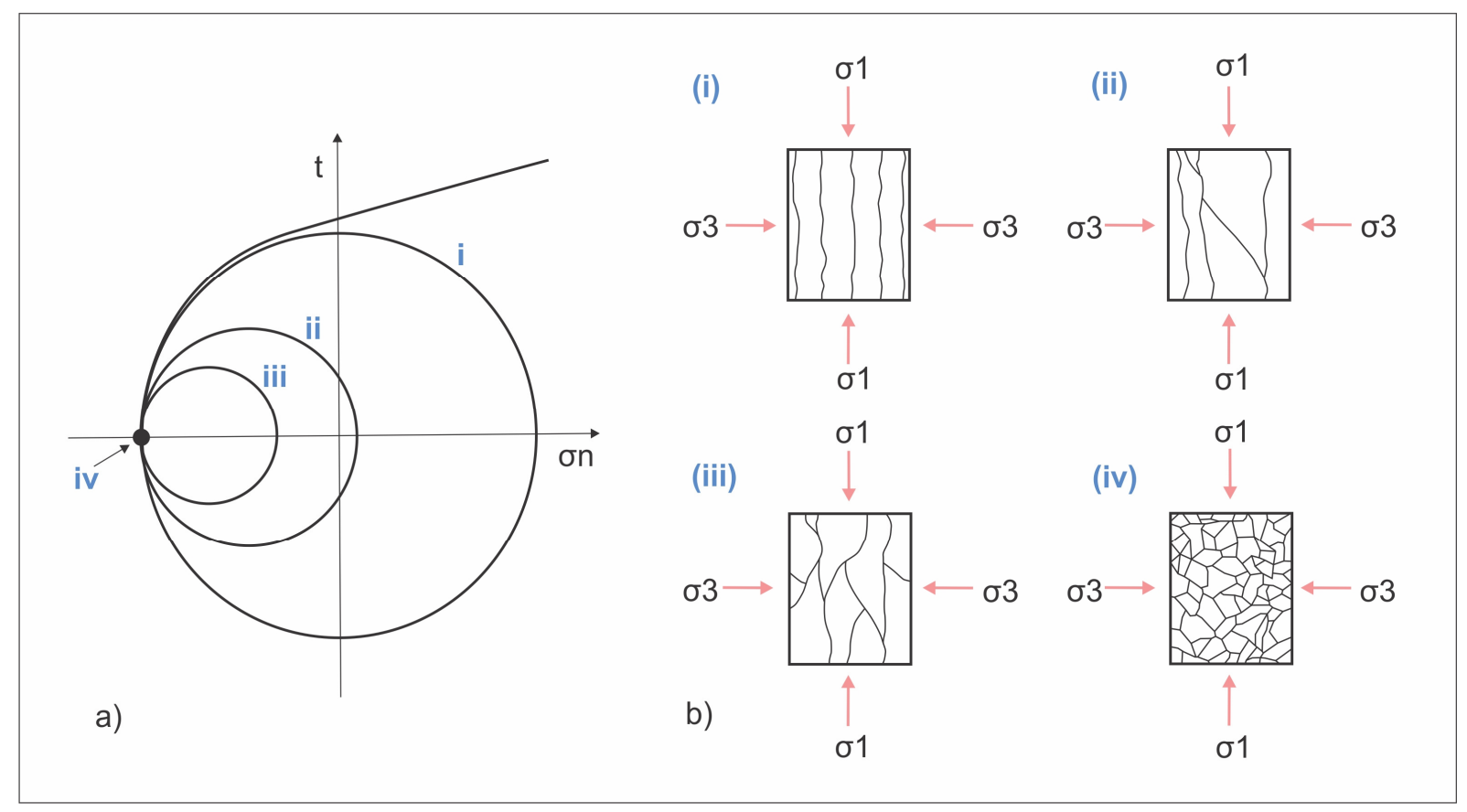

Figura 11: a) Quatro círculos de Mohr que representam quatro estados de tensão que dará origem a fraturas de distensão $((\sigma 1-\sigma 3) \leq 4 \mathrm{~T})$. b) padrões de fraturas de distensão para cada estado de tensão, diminuindo a diferença entre $\sigma 1$ e $\sigma 3$ de i para iv (extraído de Cosgrove 1998).

\subsection{Juntas}

As juntas ou diáclases são fraturas geradas pelo processo de distensão (Modo I) e não apresentam indícios de deslizamento ao longo do plano de ruptura (Marshak \& Mitra 1988, Pollard \& Aydin 1988, Price \& Cosgrove 1990, Hasui \& Mioto 1992). As juntas podem se apresentar seladas, quando o espaço entre os planos das paredes de rocha está preenchido por material tardio, podendo também se configurar como veios (Ramsay \& Huber 1987). Uma família de juntas corresponde a um conjunto de juntas sistemáticas, caracterizadas como planares, desenvolvidas paralelamente umas às outras e com a mesma orientação (Ramsay \& Huber 1987, Marshak \& Mitra 1988) (figura 12). Frequentemente, juntas não-sistemáticas, geralmente curviplanares e aleatoriamente espaçadas, podem estar dispostas de forma ortogonal às juntas sistemáticas, condicionadas pela atitude da família de juntas. Um sistema de juntas é formado por mais de uma família de juntas orientadas diferentemente, formando blocos poliédricos de dimensões variadas, e podem ser desenvolvidas ao mesmo tempo ou não (Ramsay \& Huber 1987, Marshak \& Mitra 1988, Price \& Cosgrove 1990). 

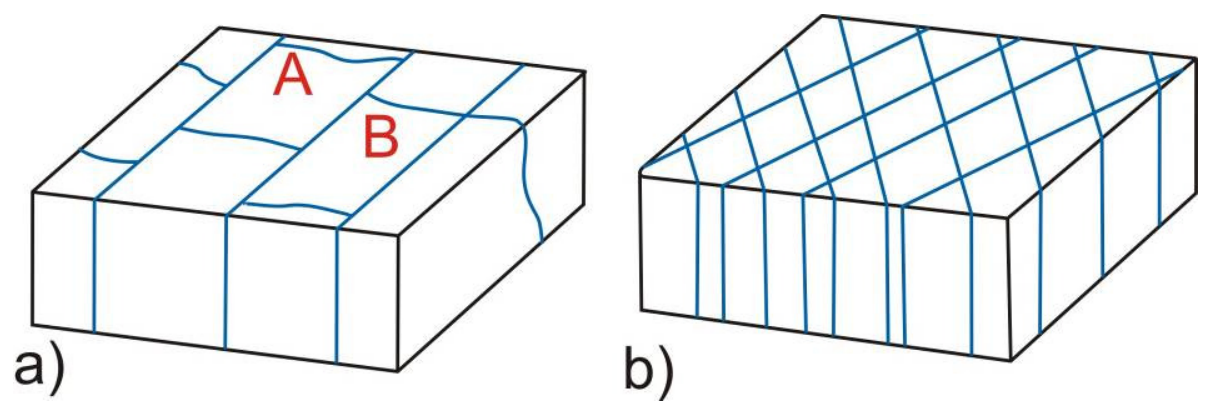

Figura 12: (a) família de juntas definida pelas juntas sistemáticas paralelas (A) e mais persistentes que as juntas não sistemáticas (B), ortogonais e de extensão limitada ao espaçamento das juntas sistemáticas; (b) Sistema de juntas composto por duas famílias de juntas (Price \& Cosgrove 1990).

As juntas são caracterizadas principalmente quanto à sua persistência ou continuidade, que corresponde à extensão em área do traço do plano da fratura. Juntas mais proeminentes de um conjunto são algumas vezes denominadas como juntas mestras. $\mathrm{O}$ espaçamento entre as juntas também é um dos parâmetros de grande importância na caracterização da estrutura, no qual se considera a distância perpendicular entre dois planos de fraturas consecutivos, de uma mesma família (Hasui \& Mioto 1992).

Do ponto de vista genético as juntas apresentam terminologias específicas. As juntas de resfriamento ou colunares são juntas formadas como resultado da contração. São normalmente definidas como juntas poligonais de ocorrência em rochas ígneas, como consequência do resfriamento da lava, e em rochas sedimentares pelo ressecamento (Ramsay \& Huber 1987, Price \& Cosgrove 1990). As juntas hidráulicas normalmente se formam em profundidade e como consequência das altas pressões de fluído (Dunne \& Hancock 1994). As juntas de descarga (unloading joint) e juntas de alívio (release joints) são formadas próximas à superfície, após ter ocorrido o soerguimento e exumação. Dunne \& Hancock (1994) consideram que a atitude das juntas de descarga é controlada pela orientação de tensões tectônicas residuais e as juntas de alívio seriam fortemente condicionadas por estruturas preexistentes. As juntas de cisalhamento (shear joints) correspondem a juntas formadas em associação às fraturas de cisalhamento (Ramsay \& Huber 1987, Price \& Cosgrove 1990). 


\subsection{Falhas}

As falhas são fraturas geradas pelos modos II e III de propagação, apresentam deslizamento paralelo ao plano de ruptura e estão associadas a movimentos cisalhantes (Marshak \& Mitra 1988, Pollard \& Aydin 1988, Price \& Cosgrove 1990). Em determinadas situações, existe certa dificuldade na identificação do deslocamento ao longo dessas estruturas, razão pela qual alguns autores acrescentaram um parâmetro de escala para a definição de falhas. Angelier (1994) define que as falhas são fraturas nas quais o deslocamento é visível a olho nu ou identificado por observação ao microscópio. Ramsay \& Huber (1987) consideram como falhas as fraturas que apresentam deslocamento diferencial maior do que 0,5 milímetros. Price \& Cosgrove (1990) sugerem que fraturas de poucos metros de extensão e que apresentam poucos milímetros de deslocamento deveriam ser descritas genericamente como fraturas de pequeno cisalhamento.

Uma zona de falha ou zona de cisalhamento rúptil corresponde a uma zona relativamente estreita com limites paralelos. É formada por uma série de falhas que separam blocos em forma de lentes de rocha indeformada, ou como bandas tabulares de largura específica contendo rocha fragmentada (Marshak \& Mitra 1988). Segundo Ramsay \& Huber (1987) as zonas de cisalhamento podem ocorrer em séries subparalelas (sub-parallel sets) ou como séries conjugadas que se interceptam (crossing conjugate sets), formadas sincronicamente.

Segundo a classificação de falhas de Sibson (1977), na porção superior da crosta as zonas de falhas têm como produto de fricção de cisalhamento materiais incoesos, conhecidos como "farinha" e "brecha de falha". Estes são termos dados aos materiais inconsolidados encontrados entre as paredes da falha, os quais frequentemente apresentam alteração intempérica e/ou hidrotermal. Os deslocamentos ao longo dos planos de falhas são principalmente reconhecidos pela presença de estrias de atrito, que auxiliam na identificação do movimento relativo dos blocos, permitindo classificar as falhas como normais, inversas e falhas com rejeito direcional com movimentação transcorrente. 


\section{FRATURAS SUB-HORIZONTAIS EM DERRAMES BASÁLTICOS DA FORMAÇÃO SERRA GERAL}

As fraturas sub-horizontais em derrames basálticos podem apresentar grande continuidade lateral. Essas estruturas são de amplo interesse às obras de engenharia e à hidrogeologia desde longa data (Guidicini \& Campos 1968, Rebouças 1978, Guidicini 1979, Giampá \& Souza 1982, Björnberg \& Kutner 1983, Rebouças \& Fraga 1988, Fernandes et al. 2008, 2010a, b). No entanto, a falta de estudos mais aprofundados sobre sua caracterização fez com que até hoje tais estruturas sejam pouco compreendidas e tratadas com termos inadequados.

As fraturas sub-horizontais de grande continuidade lateral presentes em derrames basálticos da Formação Serra Geral na Bacia do Paraná foram descritas inicialmente por Guidicini \& Campos (1968), reconhecidas através de observações diretas de áreas de escavações para construção de hidrelétricas. Essas estruturas foram intensamente investigadas por diversos autores até o início da década de 90, principalmente por trabalhos vinculados às obras de barragens implantadas sobre os derrames basálticos da Formação Serra Geral, no sudeste e sul do Brasil (figura 13).

Trabalhos de abordagem geotécnica, com o intuito de caracterização dos derrames basálticos para fundações de barragens, frequentemente relatam a ocorrência de fraturas subhorizontais de grande continuidade lateral. Descontinuidades sub-horizontais são consideradas feições de grande importância na estabilidade de fundações de barragens, pois estão sujeitas a escorregamentos e permitem alta condutividade hidráulica, em função de seu material de preenchimento (Moller \& Souza Pinto 1976, Oliveira et al. 1976, Guidicini 1979, Björnberg \& Kutner 1983, Tressoldi 1987) (figura 14). Na hidrogeologia, tais estruturas podem representar zonas de percolação preferencial, condicionando, juntamente como as camadas intertrapeadas, uma permeabilidade horizontal até duas vezes maior que a vertical (Rebouças 1978, Giampá \& Souza 1982, Lastoria et al. 2006, Fernandes et al. 2010b). 


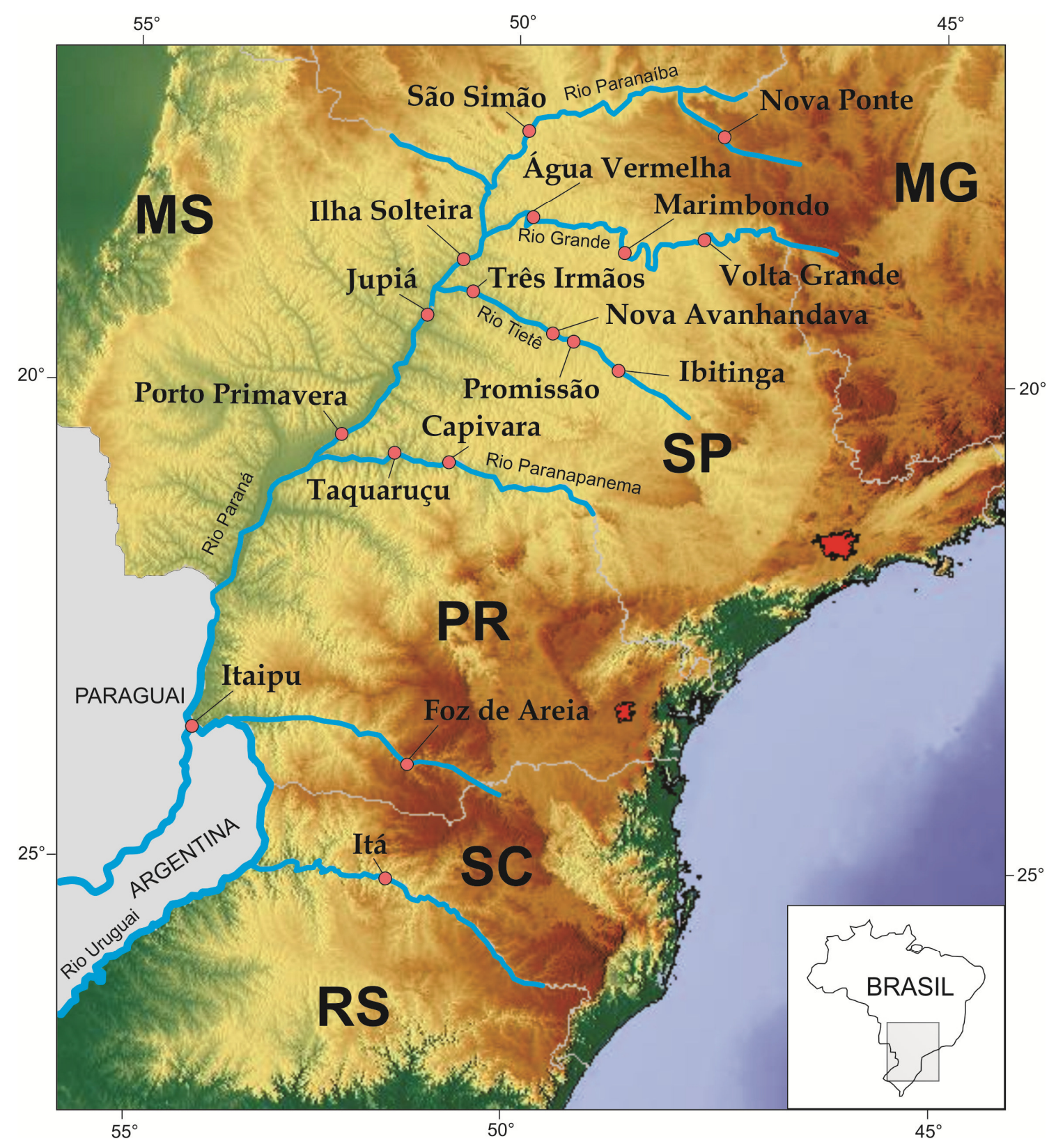

Figura 13: Localização das usinas hidrelétricas com ocorrência de fraturas de grande continuidade lateral na região centro-sul do Brasil. 

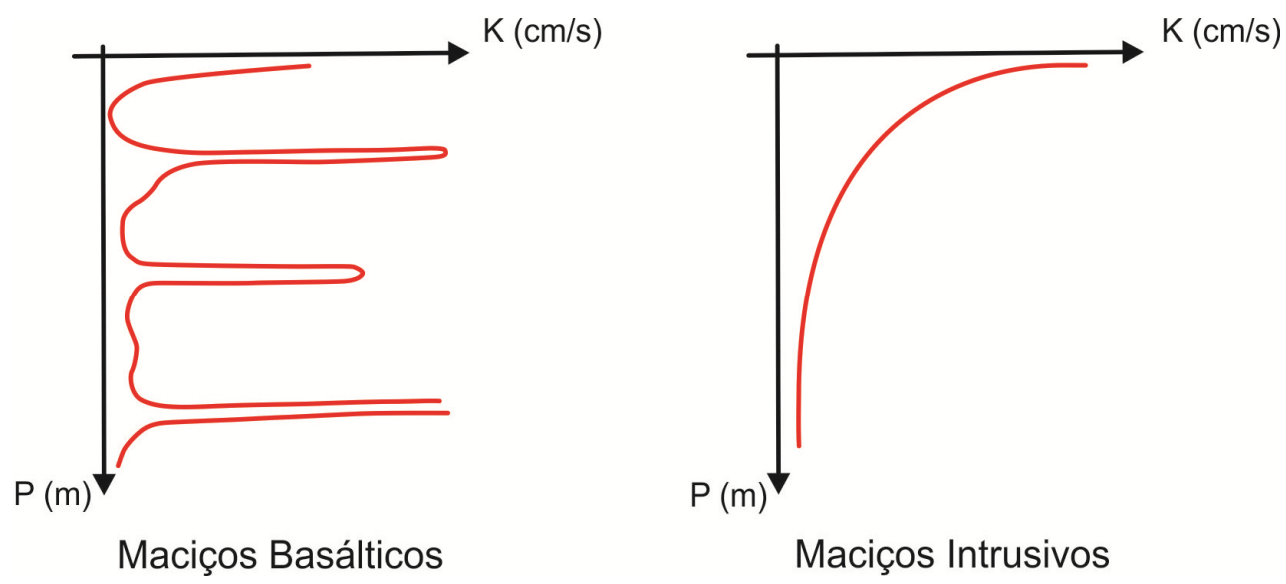

Figura 14: Esquema representativo da distribuição da permeabilidade $(\mathrm{K})$ em função da profundidade (P), comparando-se maciços basálticos (esquerda) e intrusivos (direita) (Oliveira et al. 1976).

As fraturas sub-horizontais de grande continuidade lateral foram consideradas típicas em derrames basálticos (Guidicini 1979, Björnberg \& Kutner 1983). O grande número de relatos sobre essas estruturas contribuiu para a identificação de suas diferentes feições e formas de ocorrência. No entanto, muitas dessas informações encontram-se dispersas e de difícil acesso, com publicações em simpósios, seminários e congressos específicos da área de Geologia de Engenharia. Contudo, as definições que abrangem essas estruturas ainda são confusas e pouco conclusivas, em vista da grande variedade de feições e da falta de investigações mais aprofundadas sobre seus processos geradores, relacionados a eventos sin-, tardi- e pós-magmáticos. Há que se considerar ainda que os estudos dessas feições pouco evoluíram desde o final da década de 80.

Um grande problema em torno das fraturas sub-horizontais de grande continuidade lateral diz respeito à falta de critérios de definição de fraturas. Tais estruturas são constantemente tratadas como "juntas-falhas", termo aplicado originalmente por Guidicini \& Campos (1968), que exprime a existência de duas feições ao longo de uma mesma estrutura. A adoção de um termo ambíguo abriu precedentes para generalizações, pondo em dúvida o que, na realidade, essas estruturas podem representar. Neste trabalho, foi reunido e sintetizado um grande volume de informações a respeito das fraturas sub-horizontais de grande continuidade lateral encontradas nas obras de construção de barragens. Essas estruturas são normalmente tratadas como "juntas de grande continuidade lateral" (e.g. Guidicini \& Campos 1968, Moller \& Souza Pinto 1976, Guidicini 1979), "faixas fraturadas" (e.g. Oliveira 1969, 
Nieble et al. 1974a, Moller \& Souza Pinto 1976, Oliveira et al. 1976), "juntas-falhas" (Guidicini \& Campos 1968, Guidicini 1979, Björnberg \& Kutner 1983, Souza Jr. \& Campos 1990), "falhas horizontais" (Souza Jr. \& Campos 1987b), "fraturas de descompressão" (Moller \& Cabrera 1976, Marques Filho \& Levis 1981, Marques Filho \& Geraldo 1998), "falhas em bigode" (Paes de Barros \& Guidicini 1981) e "juntas-falhas em bigode" (Björnberg \& Kutner 1983). Dentre as características apresentadas na literatura, pode-se distinguir três estruturas rúpteis distintas, dispostas sub-horizontalmente e de grande continuidade lateral (quadro 1).

Quadro 1: Síntese de denominações e definições das fraturas sub-horizontais de grande continuidade lateral.

\begin{tabular}{|c|c|c|}
\hline Denominação & Autores & Características \\
\hline \multirow{2}{*}{$\begin{array}{l}\text { JUNTA DE } \\
\text { GRANDE } \\
\text { CONTINUIDADE } \\
\text { LATERAL }\end{array}$} & $\begin{array}{l}\text { Guidicini \& Campos (1968) } \\
\text { Guidicini (1979) } \\
\text { Souza Jr. \& Campos (1987b) }\end{array}$ & Junta sub-horizontal de grande continuidade \\
\hline & Moller \& Souza Pinto 1976 & $\begin{array}{l}\text { Proeminente família de juntas pouco } \\
\text { espaçadas, definindo um horizonte fraturado } \\
\text { bastante contínuo. }\end{array}$ \\
\hline JUNTA-FALHA & $\begin{array}{l}\text { Guidicini \& Campos (1968) } \\
\text { Guidicini (1979) } \\
\text { Björnberg \& Kutner (1983) } \\
\text { Souza Jr. \& Campos (1990) } \\
\text { Brito et al. (1990) } \\
\text { Magalhães \& Cella (1998) }\end{array}$ & \multirow{2}{*}{$\begin{array}{l}\text { Estrutura sub-horizontal muito contínua } \\
\text { lateralmente, que varia desde uma junta até } \\
\text { um horizonte fraturado com feições de } \\
\text { cisalhamento de até dois metros de espessura, } \\
\text { constituído por um conjunto de fraturas } \\
\text { subparalelas, definindo blocos tabulares ou } \\
\text { em lentes. Localmente apresenta estrias de } \\
\text { fricção no material de preenchimento, } \\
\text { brechação e/ou deslocamento de feições guia. } \\
\text { As "juntas-falhas" são normalmente tratadas } \\
\text { descritivamente como "faixas fraturadas" } \\
\text { (Oliveira 1969, Oliveira } \text { et al. 1976, Nieble et } \\
\text { al. 1974b, Moller \& Souza Pinto 1976, Souza } \\
\text { Jr. 1986). }\end{array}$} \\
\hline $\begin{array}{l}\text { FALHA } \\
\text { HORIZONTAL }\end{array}$ & Souza Jr. \& Campos (1987b) & \\
\hline $\begin{array}{l}\text { FALHA EM } \\
\text { BIGODE }\end{array}$ & $\begin{array}{l}\text { Paes de Barros \& Guidicini } \\
\text { (1981) }\end{array}$ & \multirow{3}{*}{$\begin{array}{l}\text { Zonas de cisalhamento encontradas em vales } \\
\text { fluviais, abaixo do leito do rio. São } \\
\text { constituídas por zonas de falhas conjugadas } \\
\text { de baixo ângulo, com sinais de deslocamento } \\
\text { inverso. }\end{array}$} \\
\hline $\begin{array}{l}\text { JUNTA-FALHA EM } \\
\text { BIGODE }\end{array}$ & Björnberg \& Kutner (1983) & \\
\hline $\begin{array}{l}\text { FRATURA DE } \\
\text { DESCOMPRESSÃO }\end{array}$ & $\begin{array}{l}\text { Moller \& Cabrera (1976) } \\
\text { Marques Filho \& Levis (1981) } \\
\text { Marques Filho \& Geraldo (1998) }\end{array}$ & \\
\hline
\end{tabular}




\subsection{Principais características}

Inicialmente, Guidicini \& Campos (1968) descreveram as fraturas sub-horizontais de grande continuidade lateral como duas descontinuidades dentro do derrame limitando a zona de basalto maciço, uma logo abaixo da zona vesiculo-amigdaloidal do topo e outra acima da zona vesicular da base (figura 15). Tais fraturas poderiam ocorrer como simples juntas de grande continuidade lateral ou apresentarem sinais de deslocamento, como aspecto brechado e estrias de atrito, denominadas pelos autores como "juntas-falhas". Posteriormente, Guidicini (1979) observou que fraturas sub-horizontais de grande continuidade lateral poderiam estar presentes em diversas partes do derrame e não apenas delimitando as diferentes zonas morfológicas do derrame como apresentado na figura 15. Segundo os relatos encontrados na literatura, as fraturas sub-horizontais de grande continuidade lateral são comumente encontradas no limite do basalto maciço e vesiculo-amigdaloidal do topo do derrame, em meio ao basalto maciço no núcleo ou próximo a base do derrame.

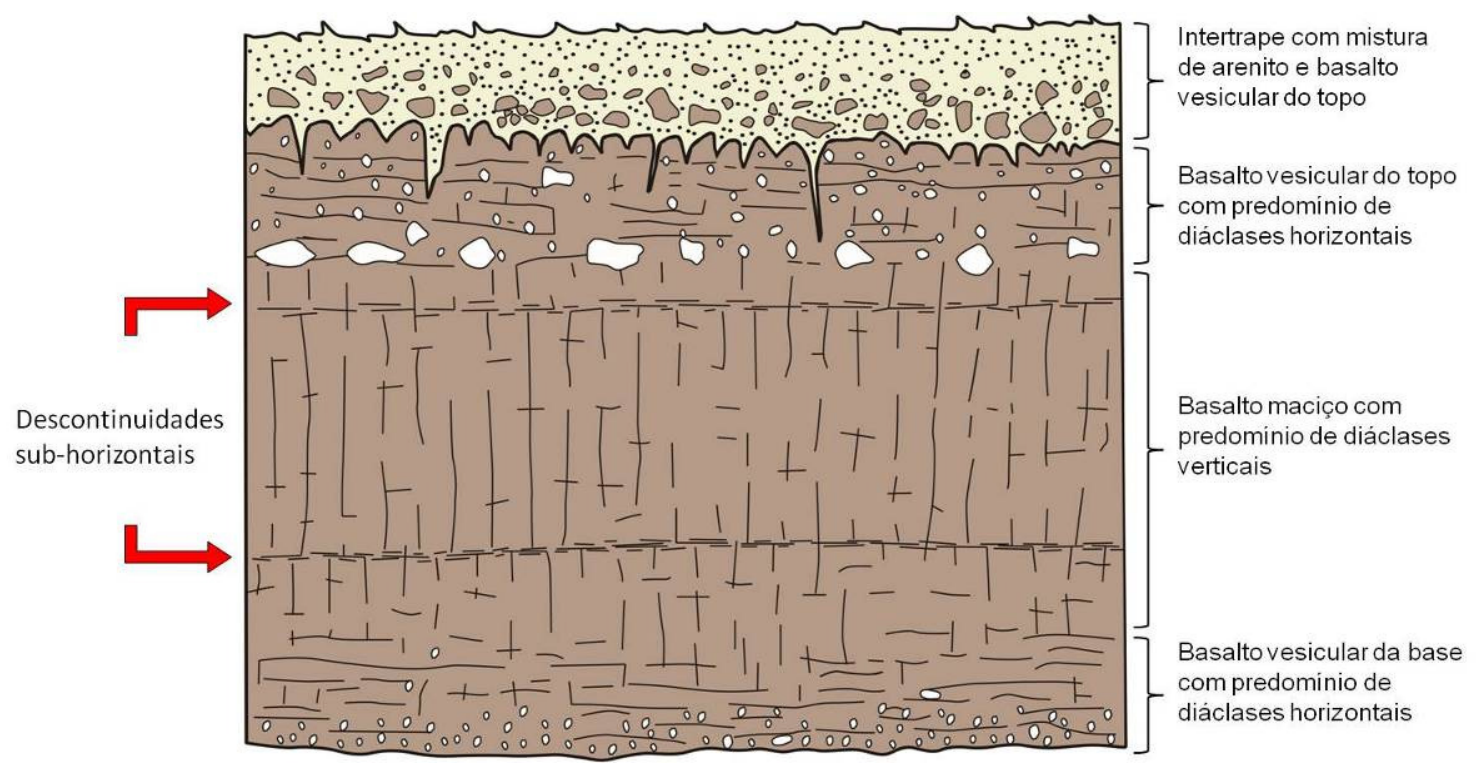

Figura 15: Seção esquemática do derrame basáltico, identificando as três zonas morfológicas: porção superficial, porção central e porção basal (Guidicini \& Campos 1968). 
As fraturas sub-horizontais de grande continuidade lateral nos derrames basálticos são relatadas como estruturas confinadas em cada derrame e sub-paralelas ao topo e à base. Não há menção de que alguma dessas estruturas tenha atravessado de um derrame a outro.

Apesar de tais estruturas serem predominantemente paralelas ao topo e base do derrame, elas podem mudar bruscamente de rumo e inclinação de mergulho, desaparecendo no topo ou na base do fluxo de lava basáltica, além de ocasionalmente apresentarem ramificações (Oliveira 1969, Guidicini 1979). Oliveira et al. (1976) apresentaram um modelo hipotético em que estão representadas estruturas recorrentes em derrames basálticos. Guidicini (1979) baseou-se nesse modelo para ilustrar formas de ocorrências de fraturas subhorizontais de grande continuidade lateral, seja como "juntas-falhas", como uma única junta muito persistente ou como um horizonte fraturado, com ampla variação de espessura e continuidade lateral (figura 16).

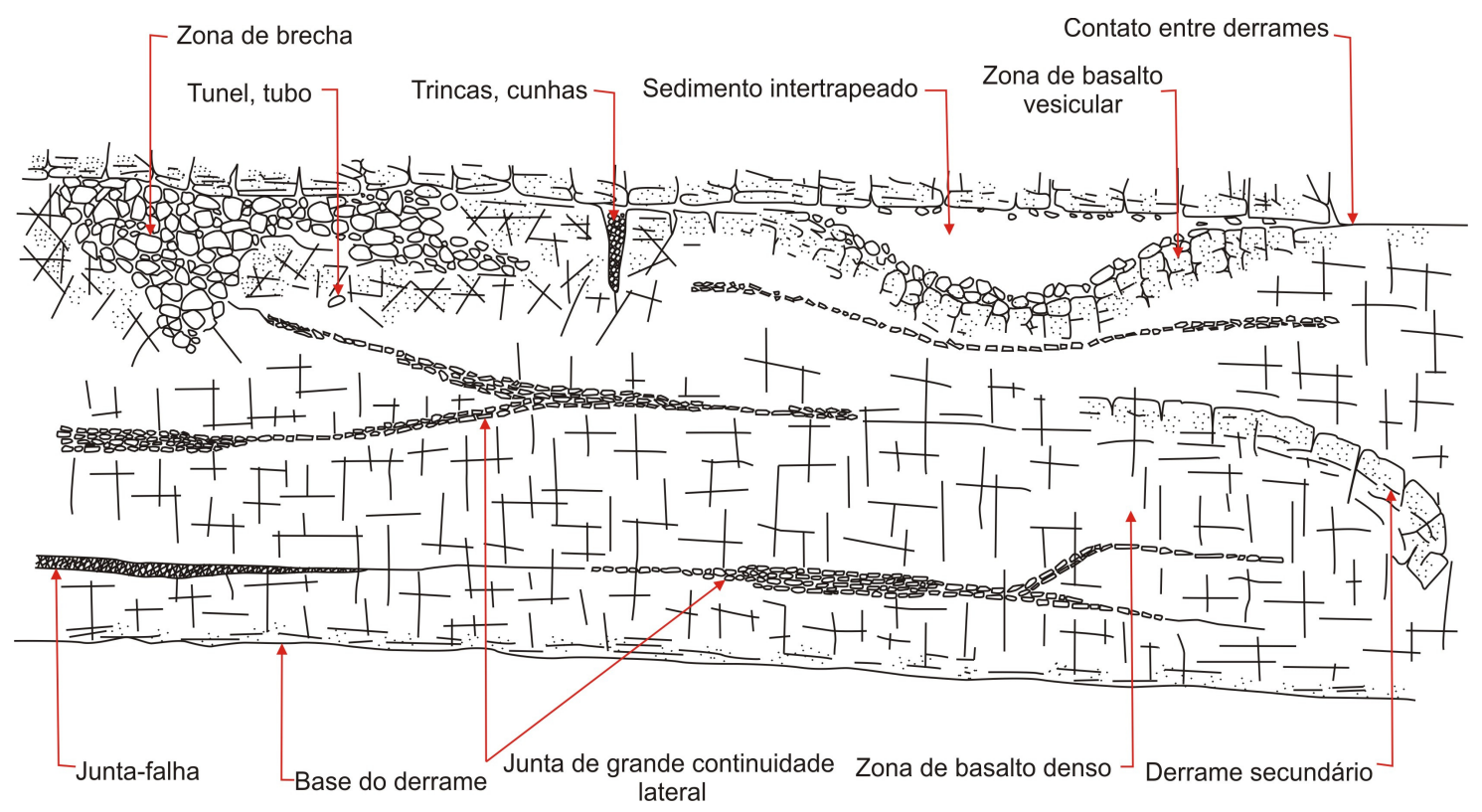

Figura 16: Modelo hipotético de um derrame basáltico com a representação esquemática das principais feições litoestruturais. Destaque para a variação lateral de uma mesma descontinuidade, ora como "junta-falha", ora como um horizonte fraturado com ampla variação de espessura (Guidicini 1979). 
As fraturas sub-horizontais de grande continuidade lateral descritas como simples juntas de grande persistência são notavelmente planares, encontram-se abertas ou com preenchimento milimétrico e estão dispostas sub-paralelamente ao topo e a base do derrame (Guidicini \& Campos 1968, Brito 1971, Moller \& Cabrera 1976, Souza Jr. 1986) (figura 17). As fraturas sub-horizontais descritas como horizontes fraturados de grande continuidade lateral são comumente referidas como zonas muito a extremamente fraturadas e designados como "faixas fraturadas" ou "feixe de juntas". Referencias sobre a ocorrência de estrias de fricção no material de preenchimento de algumas fraturas são comuns. Na literatura, tais estruturas são frequentemente designadas como "juntas-falhas" (e.g. Oliveira 1969, Brito 1971, Nieble et al. 1974a, Moller \& Cabrera 1976, Oliveira et al. 1976, Souza Jr. 1986, Mano 1987).

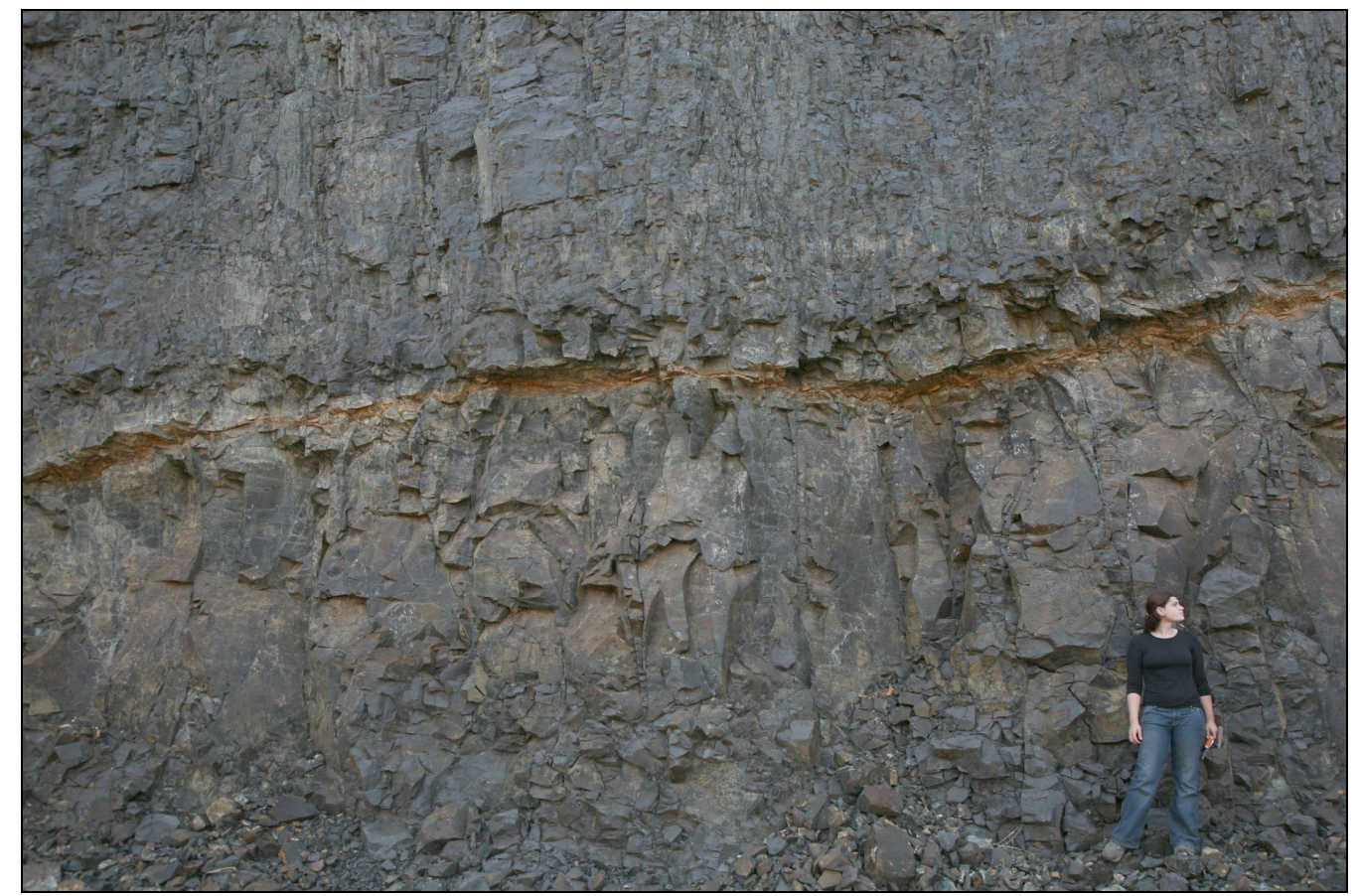

Figura 17: Junta horizontal de grande extensão em meio ao basalto maciço da Formação Serra Geral, na região de Ribeirão Preto (SP). 


\subsection{Feições associadas}

As fraturas sub-horizontais de grande continuidade lateral normalmente apresentam associação direta ou indireta com outras feições internas do derrame. Essas feições internas do derrame variam desde grandes bolsões de brecha, com preenchimento argiloso ou calcítico; mudança de comportamento de disjunções colunares de resfriamento e; diferenças texturais no basalto.

Oliveira (1969), em relatos sobre os aspectos geológicos do derrame basáltico no local da Usina de Ilha Solteira (SP-MS), descreveu a ocorrência de corpos de brecha, compostos por fragmentos de basalto e argila, associados às fraturas sub-horizontais de grande continuidade lateral. Neste local as fraturas sub-horizontais ocorrem em duas situações distintas: uma delas localizada logo abaixo da zona vesículo-amigdaloidal do topo do derrame; e a outra ocorre em meio ao basalto maciço (vide esquema figura 16). A fratura subhorizontal abaixo da zona vesiculada se prolonga lateralmente para um corpo de brecha argilosa de formato tabular, que se inclina em direção ao topo do derrame. Já a fratura subhorizontal localizada no derrame maciço desenvolve-se na base de um bolsão de brecha argilosa e se estende lateralmente. Esta última fratura apresenta estrias de atrito no material de preenchimento e por isso foi denominada como "juntas-falhas". Em trabalhos recentes para o estabelecimento de modelos de circulação de água subterrânea nos basaltos da região de Ribeirão Preto (SP), Fernandes et al. (2008, 2010b) reconheceram uma associação entre corpos de brecha, dispostos em camadas ou em grandes bolsões, ocorrendo sempre junto a fraturas sub-horizontais ou de baixo ângulo. Assim como Oliveira (1969), os autores descreveram a ocorrência de fraturas sub-horizontais pouco espaçadas na base de um nível de brecha, com registros de estrias de atrito.

Próximo ao local da Usina de Água Vermelha (SP-MS), Guidicini (1979) constatou que em meio ao basalto maciço as disjunções colunares acima da fratura sub-horizontal eram menos espessas que as colunas abaixo dela. Tais colunas também acompanhavam a ondulação da fratura sub-horizontal de grande continuidade lateral, dispostas com terminações sempre perpendiculares. Esta situação também foi observada por Moller \& Souza Pinto (1976), no local da Usina de São Simão (GO-MG), onde relataram que as disjunções colunares de resfriamento não atravessavam as fraturas sub-horizontais. Diferenças no basalto acima e abaixo da fratura de grande continuidade lateral não se restringem apenas aos aspectos 
estruturais, mas também texturais. Guidicini (1979) também observou que o basalto, acima da fratura sub-horizontal, possuía granulação mais fina e coloração acinzentada, em contraposição ao basalto de maior granulação e coloração avermelhada, abaixo.

As variações texturais no basalto, possivelmente relacionadas às fraturas subhorizontais de grande continuidade lateral, podem também ocorrer de forma mais restrita, como lentes delgadas e sub-horizontais. Durante as obras para a implantação das usinas de Ilha Solteira (SP-MS), Itaipu (PR) e Porto Primavera (SP-MS) foram observadas faixas subhorizontais delgadas de espessura decimétrica em meio ao basalto maciço, nas quais a textura do basalto passa de afanítica até fanerítica grossa, contendo até mesmo alguns fenocristais. Essas feições, relatadas por Guidicini (1979) e Souza Jr. (1986), podem ocorrer paralelamente e/ou no interior de fraturas sub-horizontais de grande continuidade lateral.

Apesar da frequência de fraturas sub-horizontais de grande continuidade lateral em derrames basálticos mais espessos, elas também são encontradas em complexos de subderrames (i.e. derrames compostos) (Moller \& Cabrera 1976, Moller \& Souza Pinto 1976). No local da barragem de São Simão, Moller \& Souza Pinto (1976) descreveram a ocorrência de fraturas sub-horizontais de grande continuidade lateral em subderrames de espessura acima de 6 metros, podendo ocorrer até duas estruturas em um mesmo subderrame, próximas à base do derrame ou abaixo da zona vesiculo-amigdaloidal do topo (figura 18).

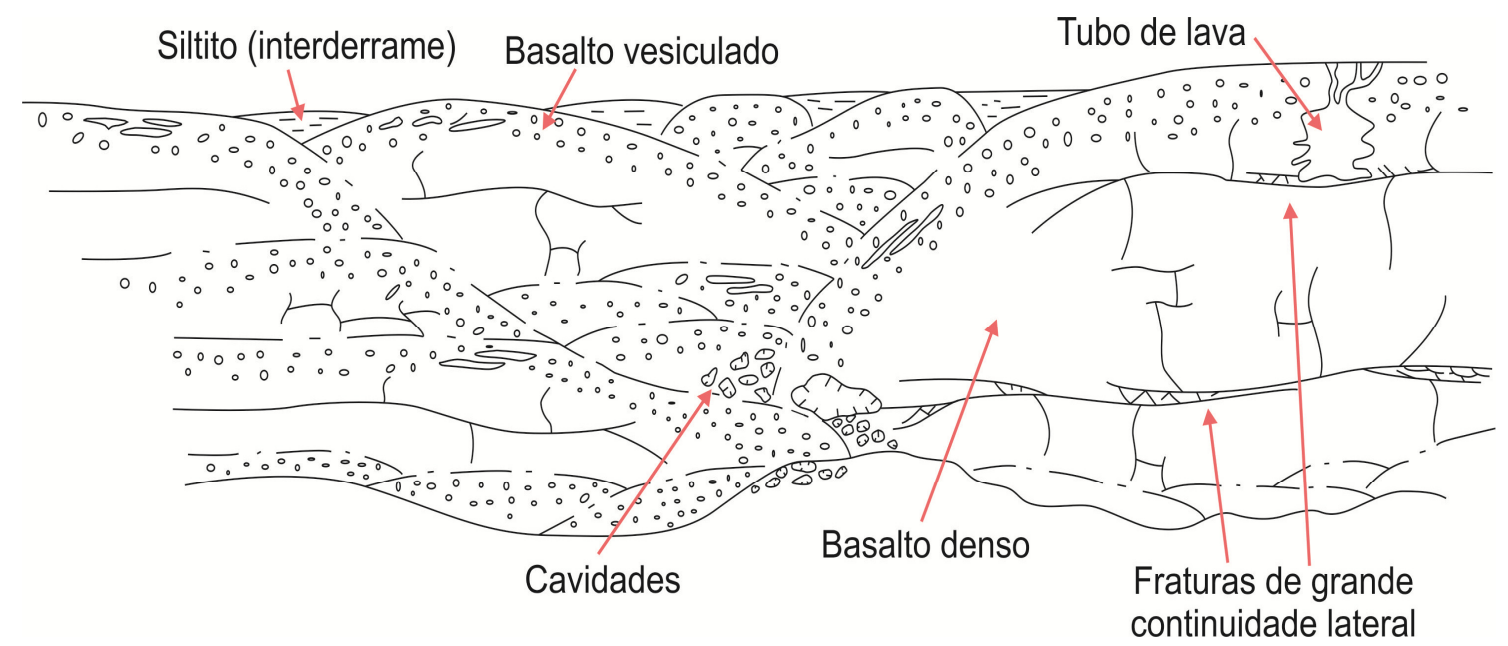

Figura 18: Esquema representativo de um complexo de subderrames em perfil, com a ocorrência de fraturas sub-horizontais de grande continuidade lateral (Moller \& Cabrera 1976). 


\subsection{As "Juntas-falhas"}

Nas primeiras descrições sobre fraturas sub-horizontais em derrames basálticos, Guidicini \& Campos (1968) observaram que algumas fraturas apresentavam um aspecto brechado, com fragmentos de basalto em meio à argila e localmente apresentavam estrias de fricção no material de preenchimento. Essas estruturas foram denominadas pelos autores como "juntas-falhas", as quais poderiam variar sua espessura significantemente. Na literatura, as fraturas sub-horizontais definidas como "juntas-falhas" correspondem a horizontes fraturados de grande continuidade lateral constituídos em geral por fraturas sub-horizontais e sub-paralelas entre elas, com pequeno espaçamento centimétrico, definindo blocos tabulares, com terminações em cunha e imbricados. Individualmente, as fraturas que constituem o horizonte fraturado normalmente são pouco persistentes, planares e curviplanares (Oliveira 1969, Moller \& Cabrera 1976, Oliveira et al. 1976, Guidicini 1979, Serra Jr. et al. 1986). O horizonte fraturado possui extensão de poucos a centenas de metros e normalmente apresentam ondulações ao longo de sua extensão. Sua espessura varia consideravelmente em uma mesma estrutura, desde poucos centímetros até dois ou três metros, porém em alguns casos a espessura pode ser mais constante e de ordem decimétrica (Guidicini \& Campos 1968, Guidicini \& Ussami 1969, Oliveira 1969, Brito 1971, Nieble et al. 1974a, Moller \& Cabrera 1976, Oliveira et al. 1976, Mano 1987, Marques et al. 1987).

As fraturas que compreendem o horizonte fraturado muito comumente estão preenchidas. As características desse preenchimento podem variar desde películas de argilominerais, calcita, siltito e material de alteração do próprio basalto com espessuras milimétricas, até zonas de aspecto brechado de espessura decimétrica, em que fragmentos de basalto tabulares ou angulosos, geralmente com avançado grau de alteração, ocorrem em meio à matriz constituída por argila, silte-arenoso, calcita e quartzo (Guidicini \& Campos 1968, Oliveira 1969, Brito 1971, Camargo et al. 1971, Oliveira et al. 1976, Guidicini 1979, Cabrera \& Barbi 1981, Paes de Barros \& Guidicini 1981, Björnberg \& Kutner 1983, Serra Jr. et al. 1986, Mano 1987). A figura 19, elaborada por Nieble et al. (1974b), ilustra em maior detalhe as feições e o preenchimento das fraturas sub-horizontais de grande continuidade lateral correspondentes às "juntas-falhas". 


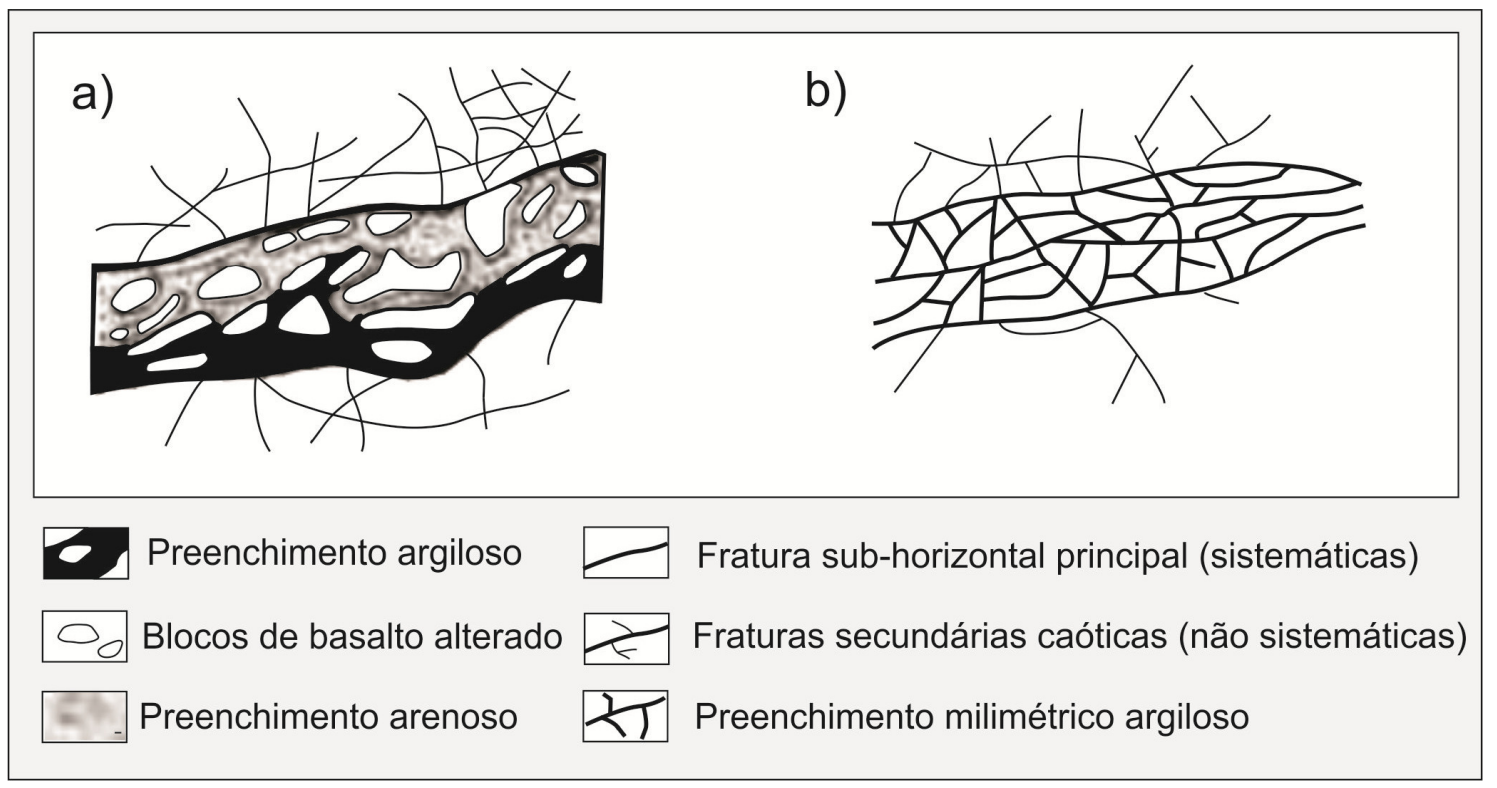

Figura 19: Feições características das "juntas-falhas" em detalhe: a) os fragmentos de basalto ocorrem em uma zona brechada, envoltos por material argiloso e arenoso de alteração; b) a "junta-falha" é definida por fraturas sub-horizontais mais persistentes (sistemáticas) e subparalelas pouco espaçadas, com pequenas fraturas curviplanares, sem orientação preferencial, em geral perpendiculares a elas (não sistemáticas) (Nieble et al. 1974b).

$\mathrm{O}$ aspecto brechado que essa estrutura muito comumente apresenta foi interpretado como "caixa de falha" (brecha de falha) por Guidicini (1979). Isso porque, em muitos casos, os fragmentos de basalto encontram-se muito cominuídos e sinais de movimentação relativa ao longo das fraturas sub-horizontais também são constantes. Essas feições se caracterizam principalmente por estrias de fricção registradas no material de preenchimento das fraturas, além de rupturas e deslocamentos de feições guia, como diques e disjunções verticais. Devido à falta de critérios básicos na definição de fraturas, Guidicini (1979) definiu as "juntas-falhas" como "juntas" sub-horizontais de grande continuidade lateral com sinais de movimentação, indicados pela presença de uma ou mais das seguintes características:

- estrias de fricção registradas no material de preenchimento;

- presença de "milonito" (referindo-se à cominuição do material - cataclasito);

- imbricação de fragmentos rochosos isorientados (figura 20);

- ruptura e deslocamento de estrato guia (figuras 21);

- deslocamentos normalmente centimétricos à decimétricos. 


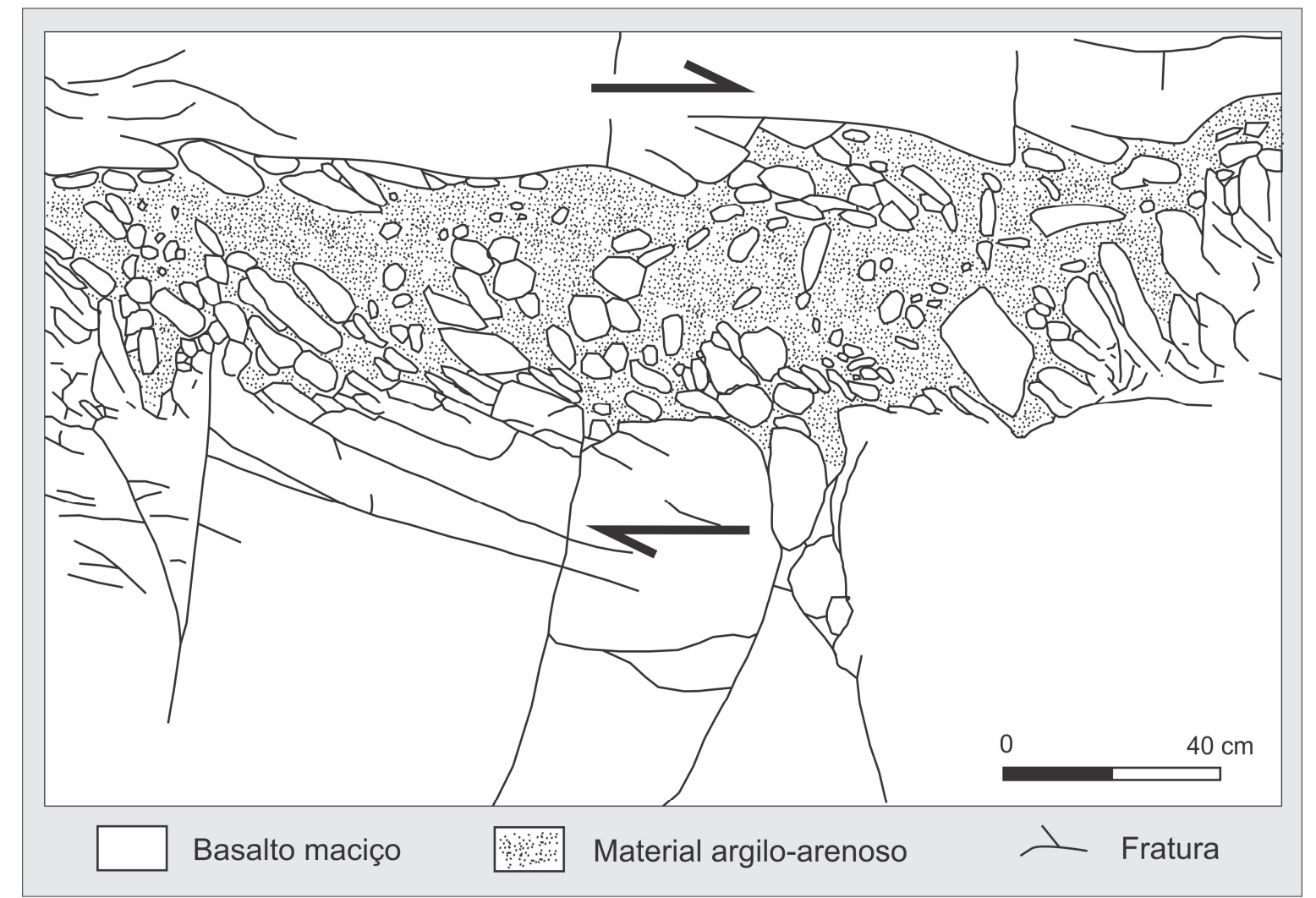

Figura 20: Representação em perfil de um horizonte muito alterado com fragmentos de basalto orientados ao longo de uma zona de cisalhamento no local da barragem de Itaipu. Sentido de deslocamento sugerido no presente trabalho. Baseado em ITAIPU BINACIONAL (1982).

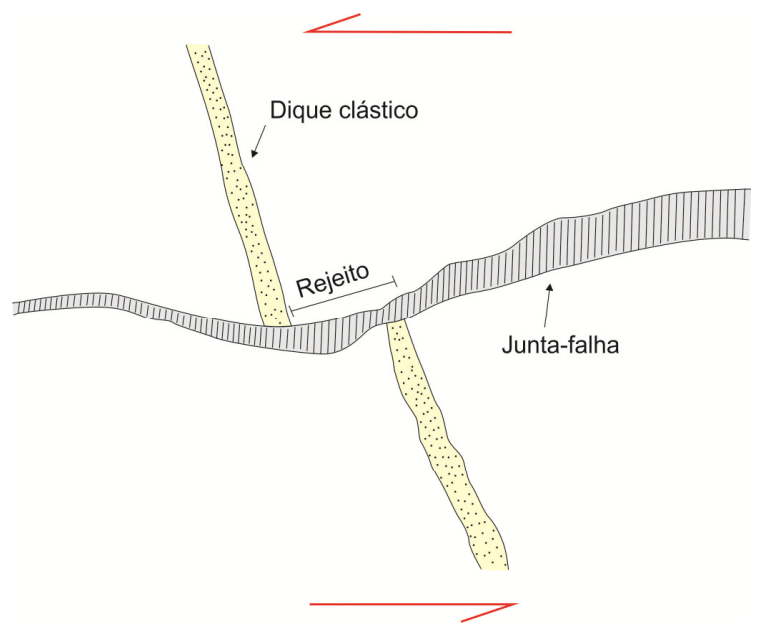

Figura 21: Esquema representativo de deslocamento ao longo da "junta-falha", com movimentação ao longo do plano sub-horizontal, tendo um dique clástico como estrutura guia. Baseado em Guidicini (1979). 
Björnberg \& Kutner (1983) associaram as "juntas-falhas” às estruturas denominadas como "falhas em bigode" por Paes de Barros \& Guidicini (1981), descritas no local da barragem de Itaipu (PR). Segundo Paes de Barros \& Guidicini (1981), as "falhas em bigode" correspondem a uma complexa zona de cisalhamento neoformada, definida por planos de falhas conjugadas abaixo do leito do rio, que se estendem lateralmente por até centenas de metros (figura 22). Individualmente, os planos de falha possuem grande continuidade lateral e comportamento espacial complexo, ora se confundindo com o contato entre derrames, ora se ramificando. Tais estruturas apresentam atitudes variáveis com mergulho entre sub-horizontal e $20^{\circ}$. As falhas se apresentam ora como horizontes extremamente alterados compostos essencialmente por material silte-arenoso, ora como horizontes intensamente fraturados com argila aderida nas paredes dos blocos (Cabrera \& Barbi 1981, ITAIPU BINACIONAL 1982).

a)

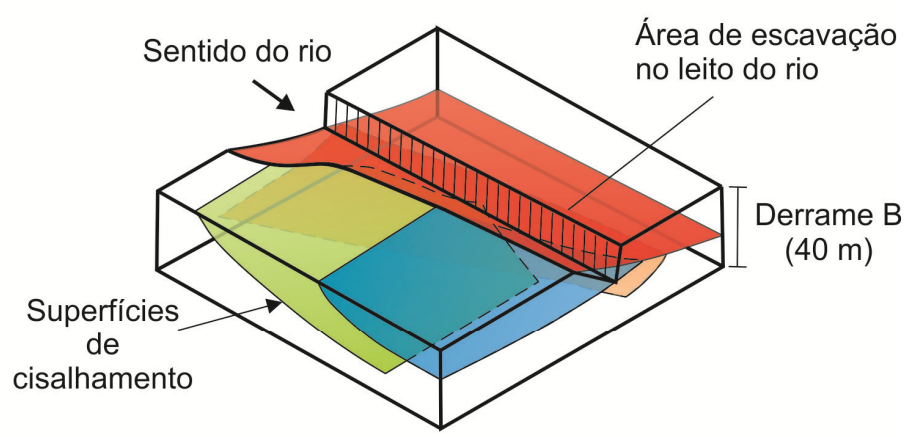

b)
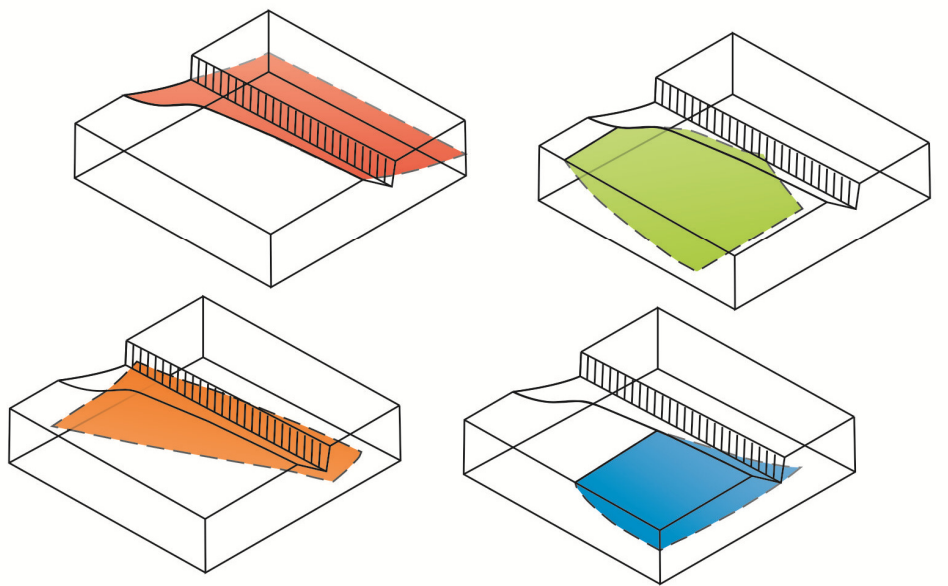

Figura 22: Blocos diagramas com a distribuição espacial das principais feições cisalhadas presentes no derrame B, abaixo do leito do rio Paraná no local da barragem de Itaipu: (a) Os planos coloridos correspondem às superfícies de fraturas de cisalhamentos de grande continuidade lateral, dispostas com padrão conjugado com sentido de mergulho variável entre sub-horizontal e $20^{\circ}$; (b) representação individual das quatro principais superfícies de cisalhamento (adaptado de ITAIPU BINACIONAL 1982). 
Björnberg \& Kutner (1983) esquematizaram as principais descontinuidades subhorizontais encontradas nos derrames basálticos no local da Usina de Itaipu (PR) (figura 23). Dentre elas, as "juntas falhas em bigode" (figura 23 a) são caracterizadas como um horizonte fraturado constituído por fraturas ramificadas e entrecruzadas, isolando blocos em forma de lentes e cunhas, em meio ao basalto maciço. As outras descontinuidades encontradas neste local correspondem a fraturas sub-paralelas com preenchimento parcial de argila (figura 23 b) e zonas brechadas sub-horizontais, com blocos angulosos e matriz silto-arenosa ou argilosa (figura 23 c e d). Björnberg \& Kutner (1983) também denominam como "junta-falha" uma descontinuidade sub-horizontal ao longo de um contato entre derrames, com siltito silicificado intertrapiado (figura $23 \mathrm{e}$ ).

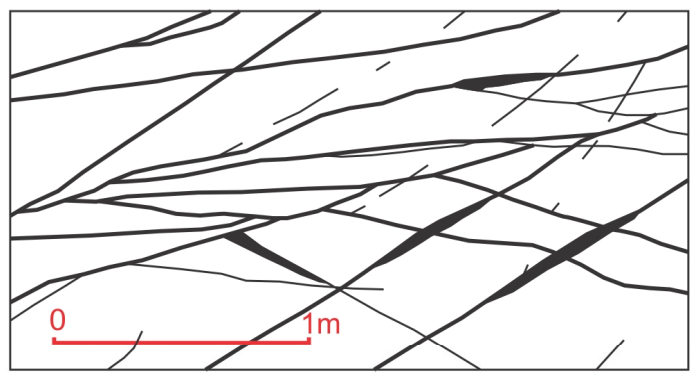

a) "Junta-falha bigode": zona fraturada constituída por fraturas ramificadas e entrecruzadas, isolando blocos em forma de lentes e cunhas, com paredes de rocha sã. Ocorrem em meio ao basalto maciço.

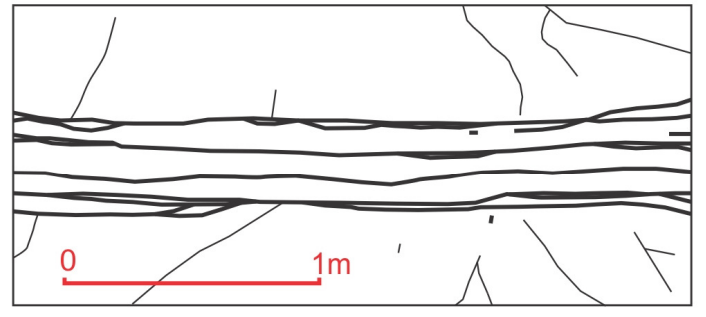

b) Zona sub-horizontal de rocha muito fraturada, com preenchimento parcial ou película argilosa aderida.

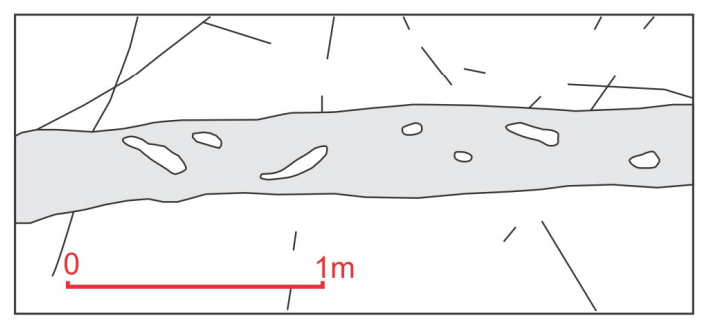

d) Fratura aberta com muita argila e fragmentos de rocha sã ou pouco alterada.

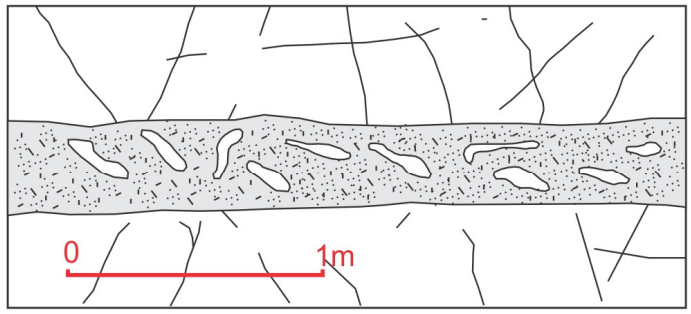

c) Zona brechada com blocos angulosos e matriz silto-arenosa.

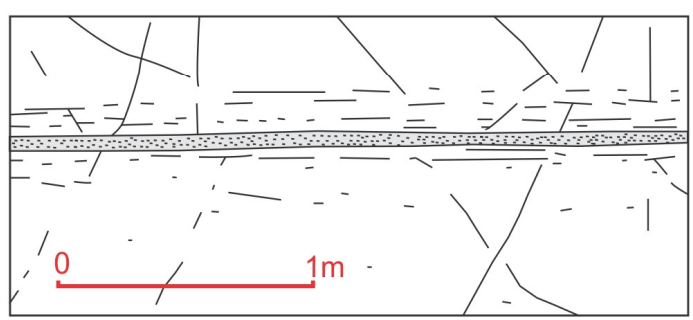

e) "Junta-falha" no contato entre derrames com siltito silicificado intertrapeado.

Figura 23: Principais aspectos das fraturas sub-horizontais observadas no local da barragem de Itaipu, em seção vertical (Björnberg \& Kutner 1983). 


\section{PROCESSOS GERADORES E DEFORMADORES DE FRATURAS SUB- HORIZONTAIS}

Os mecanismos geradores das fraturas sub-horizontais de grande continuidade lateral foram discutidos inicialmente por Guidicini \& Campos (1968), ao considerarem que juntas sub-horizontais de grande continuidade lateral e as "juntas-falhas" seriam geradas durante o fluxo da lava. Com a evolução dos conhecimentos sobre os processos de alívio de tensões pela erosão em maciços rochosos e o reconhecimentos de atividade tectônica posterior às manifestações vulcânicas da Formação Serra Geral, os modelos que discutiam a gênese das "juntas-falhas" passaram a considerar a atuação de agentes externos agindo posteriormente à consolidação do derrame.

Guidicini (1979) reconsiderou a idéia apresentada inicialmente e admitiu que as "juntas-falhas" seriam feições de dupla natureza, resultantes de duas fases distintas de deformação. Inicialmente ocorreria a formação de uma junta de grande continuidade lateral, gerada pelo resfriamento da lava com o derrame já estagnado e, posteriormente, a feição de falha seria resultante da atuação de esforços possivelmente de origem tectônica, agindo sobre a junta sub-horizontal de grande continuidade lateral preexistente.

Marques Filho \& Levis (1981) descreveram, nos derrames basálticos no local da barragem de Foz de Areia (PR), fraturas sub-horizontais de cisalhamento localizadas abaixo do leito do rio como fraturas de descompressão. Posteriormente, Paes de Barros \& Guidicini (1981) consideraram que feições semelhantes, encontradas na barragem de Itaipu (PR), seriam estruturas neoformadas, geradas por tensões residuais de origem tectônica, aliviadas durante a descompressão devido à erosão no leito do rio. Esse processo geraria uma zona de cisalhamento conjugada denominada por Paes de Barros \& Guidicini (1981) como "falha em bigode", localizada em meio ao basalto maciço abaixo do leito do rio.

Björnberg \& Kutner (1983) apresentaram uma definição generalizada com relação às "juntas-falhas", as quais poderiam ocorrer em qualquer litologia. As "juntas-falhas" corresponderiam a zonas de cisalhamento desenvolvidas ao longo de estruturas preexistentes, como juntas sub-horizontais e contatos entre derrames, ou como estruturas neoformadas, configurando feições "em bigode" no leito dos rios. Com base nas observações de Paes de Barros \& Guidicini (1981), Björnberg \& Kutner (1983) apresentam um modelo de gênese das "juntas-falhas" como um processo conjunto de desconfinamento de tensões verticais em vales 
fluviais e esforços compressivos horizontais ligados a movimentações de grandes falhas transcorrentes na bacia.

Souza Jr. \& Campos (1987b) reconheceram a existência de dois tipos de "juntasfalhas", primárias e secundárias. Por considerarem o termo "junta-falha" inadequado, os autores propuseram o termo "falhas horizontais" e as classificaram como falhas horizontais de origem primária e falhas horizontais de origem secundária. No caso das falhas primárias, os autores seguiram a idéia inicial de Guidicini \& Campos (1968), de que tais estruturas seriam desenvolvidas concomitantemente ao fluxo e resfriamento da lava. As falhas secundárias seriam resultantes de esforços cisalhantes relacionados a movimentos de subsidência da bacia e do alívio de tensões pelo processo de entalhe do rio. Tais esforços cisalhantes agiriam sobre descontinuidades preexistentes, como juntas sub-horizontais de grande continuidade lateral e "falhas horizontais de origem primária". Brito et al. (1990) defenderam a manutenção do termo "junta-falha", devido sua característica variável, ora como junta e ora como falha, em uma mesma estrutura, já que as feições de cisalhamento ocorrem apenas localmente, e não ao longo de toda a fratura.

O fluxograma da figura 24 demonstra como os termos foram aplicados ao longo do tempo e as principais características dessas estruturas (quadro 1). Nota-se que entre 1968 e 1987, período em que tais estruturas foram estudadas com maior detalhe, as "juntas-falhas" receberam diferentes interpretações quanto à sua gênese. 


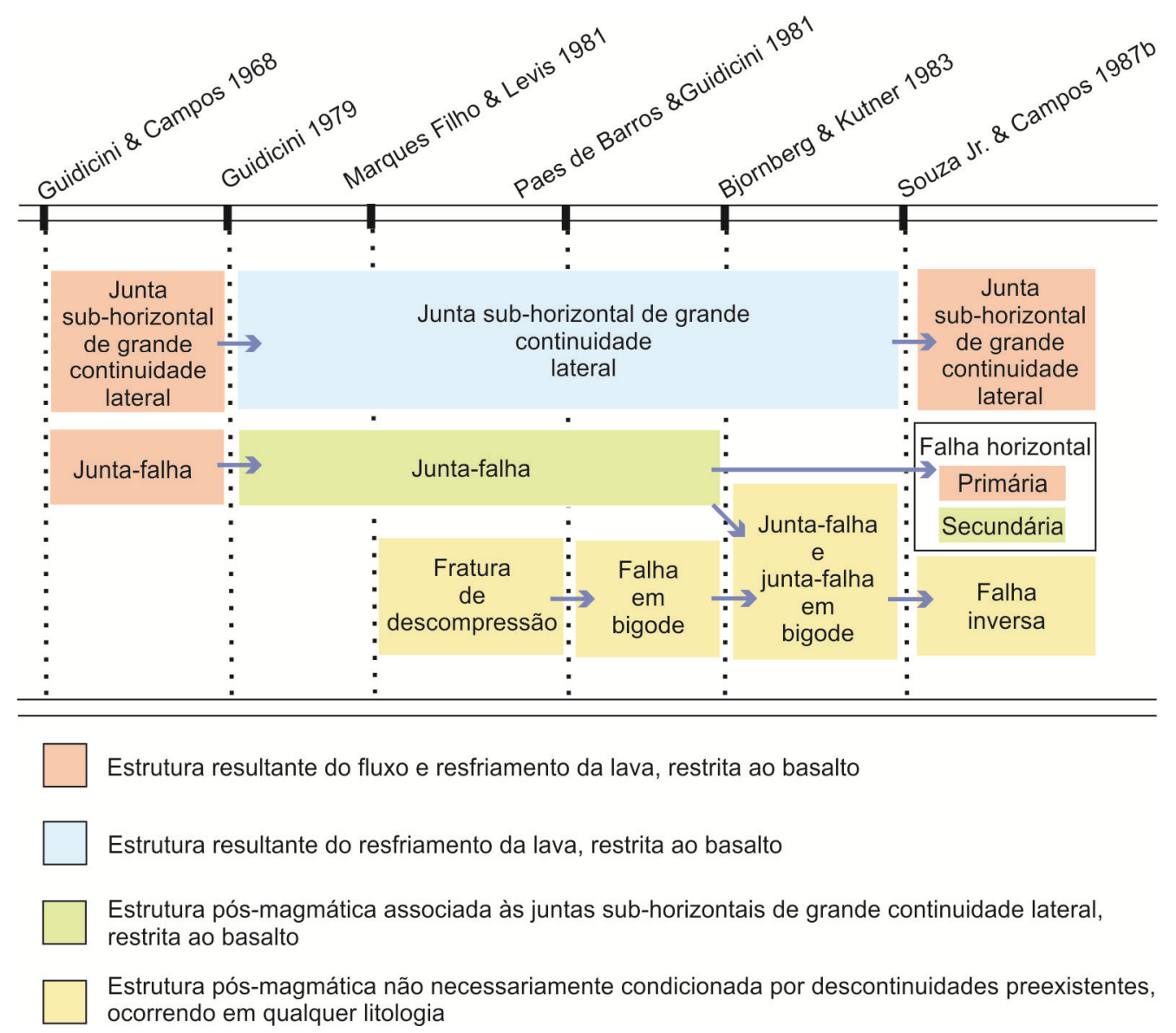

Figura 24: Fluxograma ilustrando a evolução dos termos aplicados às fraturas sub-horizontais em basalto e suas principais características.

Em trabalhos mais recentes permanecem as divergências quanto às características e processos geradores das “juntas-falhas”. Magalhães \& Cella (1998) consideraram as "juntasfalhas" como estruturas atectônicas correlatas às juntas de alívio, geradas por processos geomorfológicos de entalhe de vales fluviais. No entanto, argumentaram que a gênese de tais estruturas pode estar associada a outros processos ainda não claramente definidos. Maciel Filho (2008) defendeu as idéias de Souza Jr. \& Campos (1987b), considerando as "juntasfalhas" como falhas horizontais geradas durante a movimentação e resfriamento da lava (primárias) e/ou após seu resfriamento, por processos tectônicos ou geomorfológicos (secundárias).

A seguir, são apresentadas e discutidas as hipóteses sugeridas ao longo dos anos para a gênese das fraturas sub-horizontais de grande continuidade lateral. Os processos geradores de 
tais fraturas, bem como os agentes externos que podem condicionar seu desenvolvimento, são discutidos dentro do quadro de eventos, sin-, tardi- e pós-magmáticos.

\subsection{Processos sin-magmáticos}

A grande maioria dos estudos sobre derrames da Formação Serra Geral abordam de forma mais ampla seu aspecto geoquímico (e.g. Piccirillo \& Melfi 1988, Nardy et al. 2002, Peate et al. 1992), sendo que os aspectos reológicos das lavas vulcânicas são tratados em alguns estudos voltados às lavas de caráter ácido (e.g. Nardy et al. 2008). As características estruturais dos derrames de lavas básicas já foram abordadas em diversos aspectos (Leinz 1949, Leinz et al. 1966, Waichel 2006, Dutra et al. 2008, Ferreira et al. 2008), porém são poucos os trabalhos recentes que discutem possíveis processos geradores de fraturas subhorizontais em derrames basálticos (e.g. Arioli et al. 2008, Fernandes et al. 2008, 2010a, b).

As fraturas sin-magmáticas são aqui entendidas como aquelas geradas ainda durante o fluxo da lava basáltica. Na literatura, as hipóteses para sua gênese estão relacionadas à diferença de viscosidade pelo resfriamento da lava e pela diferenciação textural do basalto.

As porções periféricas dos derrames basálticos são constituídas por basalto vesicular e amigdaloidal. Essas porções definem nos derrames zonas normalmente caracterizadas por um intenso diaclasamento horizontal (Leinz et al. 1966, Guidicini \& Campos 1968, Kulkarni et al. 2000, Smith 2004). As diáclases horizontais e sub-horizontais das porções periféricas dos derrames são paralelas ao topo e base e normalmente mais expressivas na porção basal do derrame (figura 25). Caracterizam-se como lâminas sobrepostas pouco espaçadas, definindo sistema de fraturas curtas (centimétricas), sub-paralelas ou truncadas (Guidicini \& Campos 1968, Barcha \& Arid 1975, Giampá \& Souza 1982, Björnberg \& Kutner 1983, Arioli 2008). 


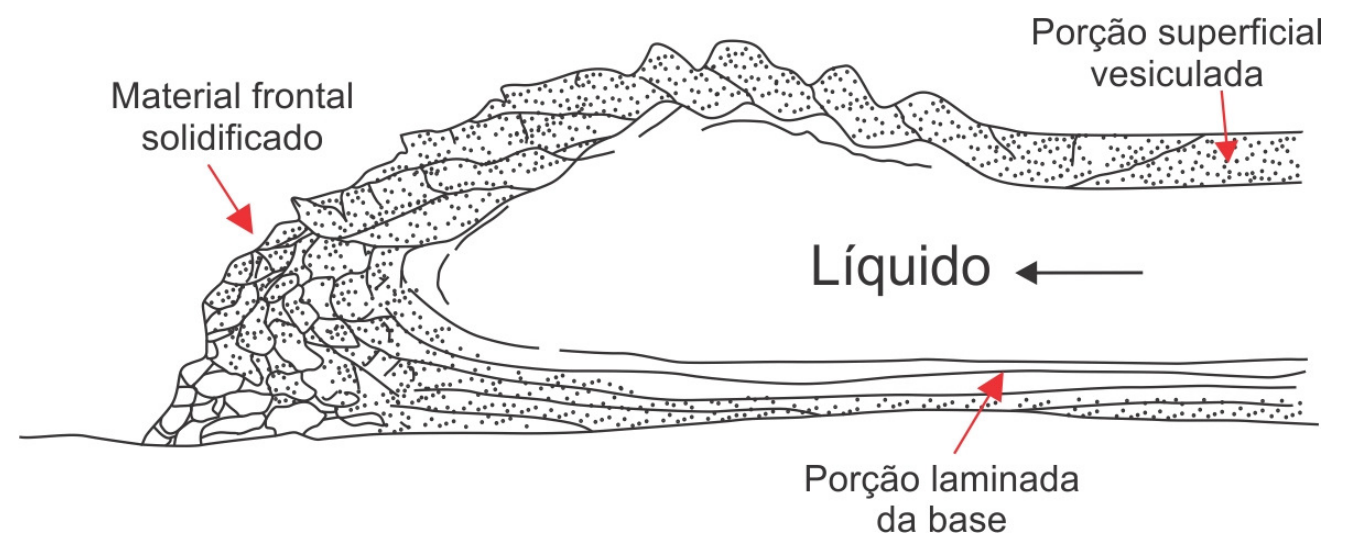

Figura 25: Esquema de um derrame em perfil, com a representação de um intenso fraturamento na porção frontal e diáclases horizontais na base do derrame (Bagolini 1971).

As diáclases horizontais das porções periféricas dos derrames foram definidas por MacDonald (1967) como proeminentes juntas horizontais planas, geralmente muito pouco espaçadas, que davam a alguns derrames um aspecto foliado, normalmente acompanhando as superfícies de topo e base do derrame. Esse aspecto foliado resultaria da tendência do movimento do fluxo continuar após a lava se tornar mais viscosa. Este efeito, no entanto, seria mais frequente em lavas mais viscosas, do que os fluxos basálticos, sendo especialmente notável em basaltos andesíticos, andesitos, e lavas com maior viscosidade (MacDonald 1967).

O primeiro modelo de gênese sin-magmática das fraturas de grande continuidade lateral foi apresentado por Guidicini \& Campos (1968), baseado em esquemas de fluxo de derrame elaborados por Bagolini (1964 apud Guidicini \& Campos 1968) para relatórios internos da empresa de engenharia responsável por projetos de construção de barragens, posteriormente publicados em Bagolini (1971). Neste modelo, o processo de resfriamento da lava provoca um aumento da viscosidade da periferia para o centro do derrame, gerando gradativamente zonas sub-horizontais de diferentes velocidades de fluxo durante o deslocamento da lava. Segundo Guidicini \& Campos (1968), quando a plasticidade do magma atinge um valor crítico de ruptura na porção central do derrame, dois planos sub-horizontais contínuos, definidos como duas juntas sub-horizontais de grande continuidade, se formariam em meio ao basalto maciço (figura 26). 


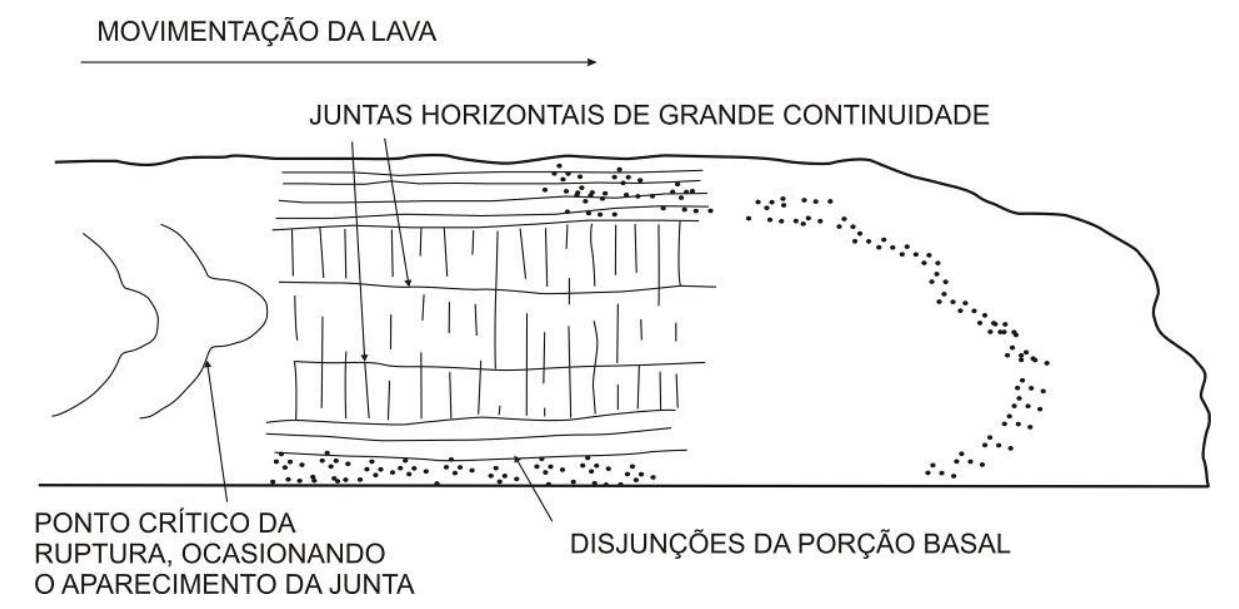

Figura 26: Modelo de gênese das fraturas de grande continuidade lateral, em função das diferentes velocidades de fluxo, pela diminuição da viscosidade das bordas para o centro do derrame. Adaptado de Guidicini \& Campos (1968).

As "juntas-falhas" corresponderiam a fraturas de cisalhamento ao longo desses horizontes, geradas por um processo caracterizado como "auto-tectonismo" por Guidicini \& Campos (1968), no qual as tensões cisalhantes seriam decorrentes da movimentação da lava. Posteriormente, Guidicini (1979) questionou este modelo e observou que a movimentação da lava básica ainda em estado fluido, mesmo que altamente viscosa, não causaria o cisalhamento sub-horizontal observado no núcleo do derrame. Tais estruturas seriam geradas pelo resfriamento da lava com o derrame estagnado e as feições de cisalhamento observadas ao longo da descontinuidade seriam decorrentes de esforços compressivos, possivelmente de origem tectônica, após a consolidação do derrame. No entanto, Souza Jr. \& Campos (1987b) consideram válido o modelo de Guidicini \& Campos (1968) e estabelecem que tais estruturas deveriam ser tratadas como juntas de grande continuidade lateral, quando não apresentam sinais de cisalhamento, ou como falhas sub-horizontais de origem primária, quando esses sinais estão presentes.

Souza Jr. \& Campos (1987b) apresentaram um segundo modelo para a gênese das fraturas sub-horizontais de grande continuidade lateral, denominadas como falhas subhorizontais de origem primária. Este modelo foi baseado nas observações de Souza Jr. (1986), na qual, lentes de textura fanerítica com fenocristais podem ocorrer paralelas e/ou no interior das fraturas sub-horizontais de grande continuidade lateral em meio ao basalto maciço. Segundo Souza Jr. (1986), lentes compostas essencialmente por plagioclásio, piroxênio, 
minerais opacos e clorita em meio ao derrame basáltico corresponderiam a camadas de fluxo, conforme Wernick \& Souza (1971). O modelo de Souza Jr. \& Campos (1987b) consiste em uma sucessão de eventos na qual, inicialmente, o núcleo do derrame, em processo de cristalização, apresentaria corpos lenticulares em estado menos viscoso. Em seguida, a movimentação diferencial do "fluxo-laminar", anteriormente à formação de diáclases subverticais de resfriamento, causaria as fraturas sub-horizontais como juntas e/ou como falhas no núcleo do derrame (figura 27).

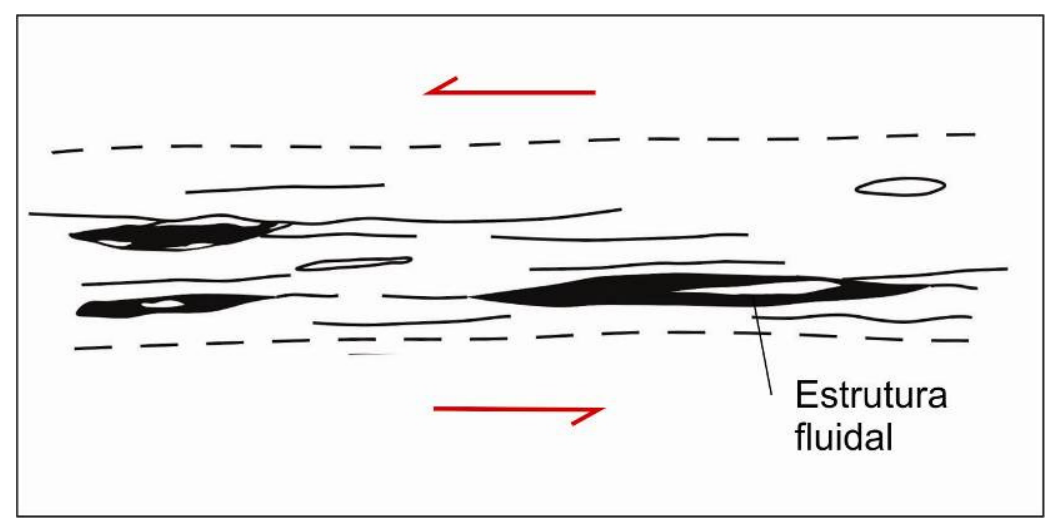

Figura 27: Modelo de formação de "juntas-falhas" de origem primária pela diferença de velocidade de fluxo causada por camadas de fluxo (estrutura fluidal) no derrame (adaptado de Souza Jr. 1986).

O modelo apresentado por Souza Jr. \& Campos (1987b) para a geração de falhas primárias considera que no núcleo dos derrames de lava básica poderiam existir condições rúptil-dúcteis, com temperatura suficientemente baixa a ponto de fraturar a rocha e gerar falhas e, ao mesmo tempo, viscosidade baixa o bastante para promover a movimentação da lava. Para essas conclusões, Souza Jr. \& Campos (1987b) se apoiaram nas considerações de MacDonald (1967), de que a rápida movimentação diferencial da lava causaria sua fragmentação mesmo antes da completa solidificação da lava. No entanto, as considerações de MacDonald (1967) se referem às diáclases sub-horizontais nas zonas periféricas do derrame, no qual é considerado o rápido resfriamento e o atrito da superfície de fluxo, e não na zona central do derrame, como foi proposto por Souza Jr. \& Campos (1987b). Além disso, Wernick \& Souza (1971) não apontaram a ocorrência de fraturas sob camadas de fluxo, permanecendo 
a dúvida se esse processo seria capaz de fraturar a lava no núcleo do derrame de caráter básico em estado ainda plástico.

Segundo Gomes (1996), o episódio de solidificação (cristalização) do derrame ocorre entre a temperatura liquidus e solidus $\left(1200\right.$ e $\left.980^{\circ} \mathrm{C}\right)$ e, posteriormente, tem início a propagação das fraturas de resfriamento, que começam a se estabelecer logo após a solidificação $\left(900^{\circ} \mathrm{C}\right)$, primeiramente nas regiões próximas as bordas do corpo e mais tardiamente no centro do derrame $\left(750^{\circ} \mathrm{C}\right)$, com o arcabouço cristalino em estágio avançado de cristalização. Fraturas milimétricas que por ventura se formem sob altas temperaturas e antes da completa solidificação da rocha (fraturas precoces) ocorrem quando o stress termal não provoca ruptura e sim deslocamento do líquido residual. Essas fraturas na verdade correspondem a pequenos veios de composição semelhante à da mesóstase.

Modelos recentes de fluxos de derrames compostos da Formação Serra Geral sugerem a ocorrência do processo de "inflação" (Waichel 2006). O processo de inflação consiste inicialmente na formação de pequenos lobos de lava basáltica. O resfriamento rápido das porções periféricas do derrame enrijece as crostas superior e inferior e, com a contínua injeção de lava, ocorre a inflação do derrame (Self et al. 1997). Arioli et al. (2008) discutem que diáclases sub-horizontais tabulares encontradas na base da porção vesicular do topo do derrame poderiam estar associadas ao processo de inflação. Segundo os autores, as disjunções tabulares poderiam ser geradas pela injeção de lava tardia no derrame, como consequência da ação de esforços compressivos provocados por fluxos, promovendo o deslizamento e truncamento de placas de basalto na zona abaixo da crosta enrijecida (figura 28). 


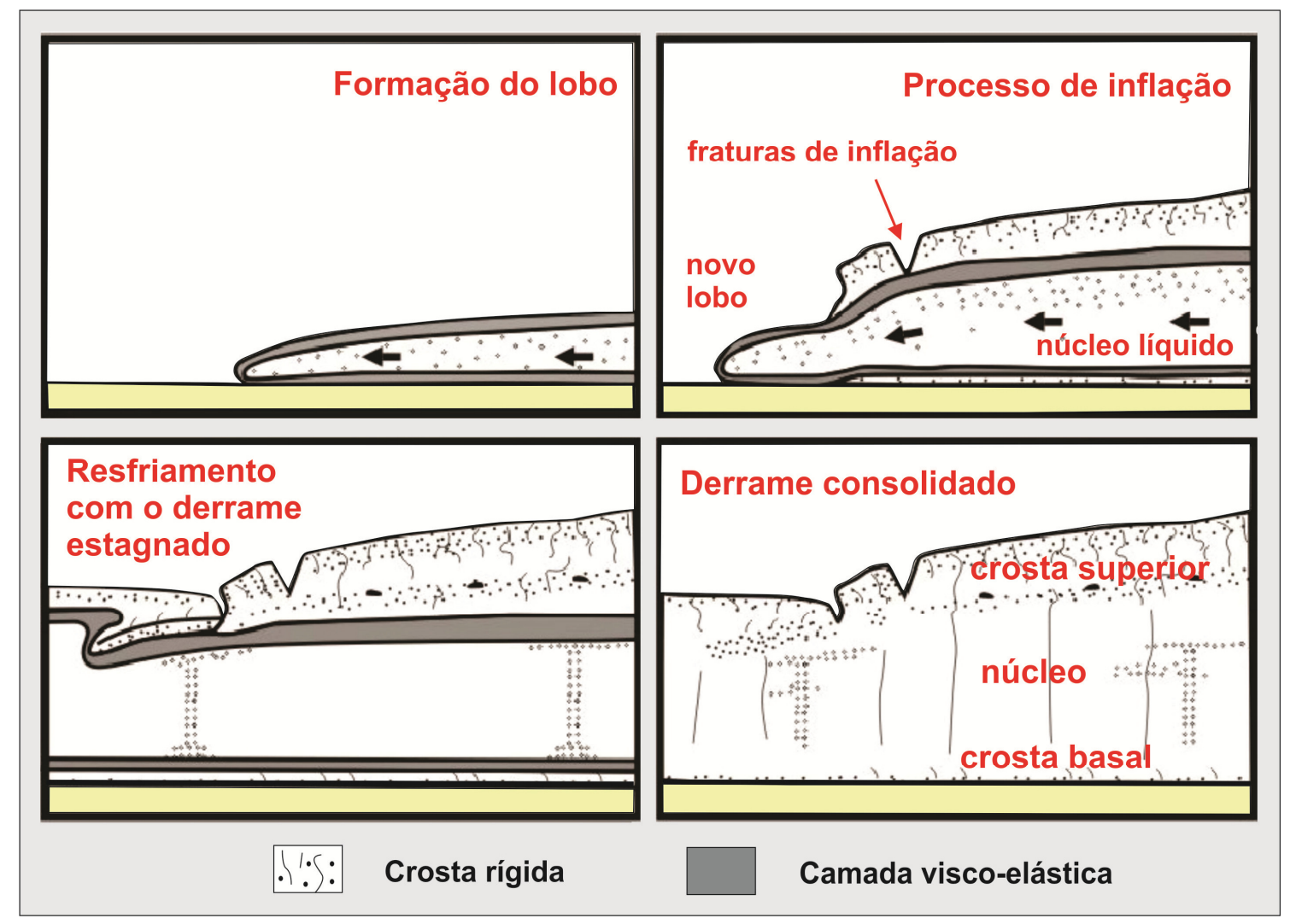

Figura 28: Modelo evolutivo do processo de inflação de derrame, seguindo uma ordem cronológica de eventos, na sequência a, b, c e d. Na interpretação de Arioli et al. (2008), as diáclases sub-horizontais tabulares se formariam abaixo da crosta superior, onde a lava apresenta um caráter visco-elástico. Adaptado de Self et al. (1997).

Fraturas sub-horizontais geradas pela ação do fluxo da lava são feições comumente encontradas em fluxo de lavas ácidas (Nardy et al. 2008). No caso das lavas básicas, não é comum a geração de tensões internas pelo fluxo devido a sua baixa viscosidade. No entanto, são frequentes referências a fraturas sub-horizontais da porção basal dos derrames basálticos, bem como logo abaixo da zona vesiculo-amigdaloidal do topo (e.g. Guidicini \& Ussami 1969, Oliveira 1969, Brito 1971, Barcha \& Arid 1975, Moler \& Cabrera 1976, Giampá \& Souza 1982, Arioli 2008). Dessa forma, a hipótese da geração de fraturas sub-horizontais por esforços compressivos devido ao fluxo da lava parece plausível, porém necessita de maiores investigações. 


\subsection{Processos tardi-magmáticos}

As fraturas tardi-magmáticas correspondem àquelas ligadas ao processo de resfriamento da lava. O processo de fraturamento em derrames desenvolve-se por frentes isotermais de resfriamento sub-horizontais que migram do topo e da base para o centro do derrame, formando as disjunções colunares, perpendiculares às frentes de resfriamento (Spry 1962, Goehring \& Moris 2008). A velocidade de propagação das fraturas é maior do topo para o centro do derrame, pois a frente de solidificação superior perde calor para a atmosfera mais rapidamente do que a frente de solidificação inferior, que perde calor por condução para o substrato (Lyle 2000). Em ambientes úmidos, a água que infiltra ao longo das primeiras juntas a se formarem (juntas mestras) modifica as frentes isotermais de resfriamento, ordenadas quase horizontalmente. Isso permite o desenvolvimento de juntas colunares curvadas (entablamento) ao longo da frente de resfriamento descendente, enquanto se formam juntas colunares mais regulares ao longo da frente de resfriamento ascendente (colunata inferior) (Lyle 2000, Goehring \& Moris 2008) (figura 29).

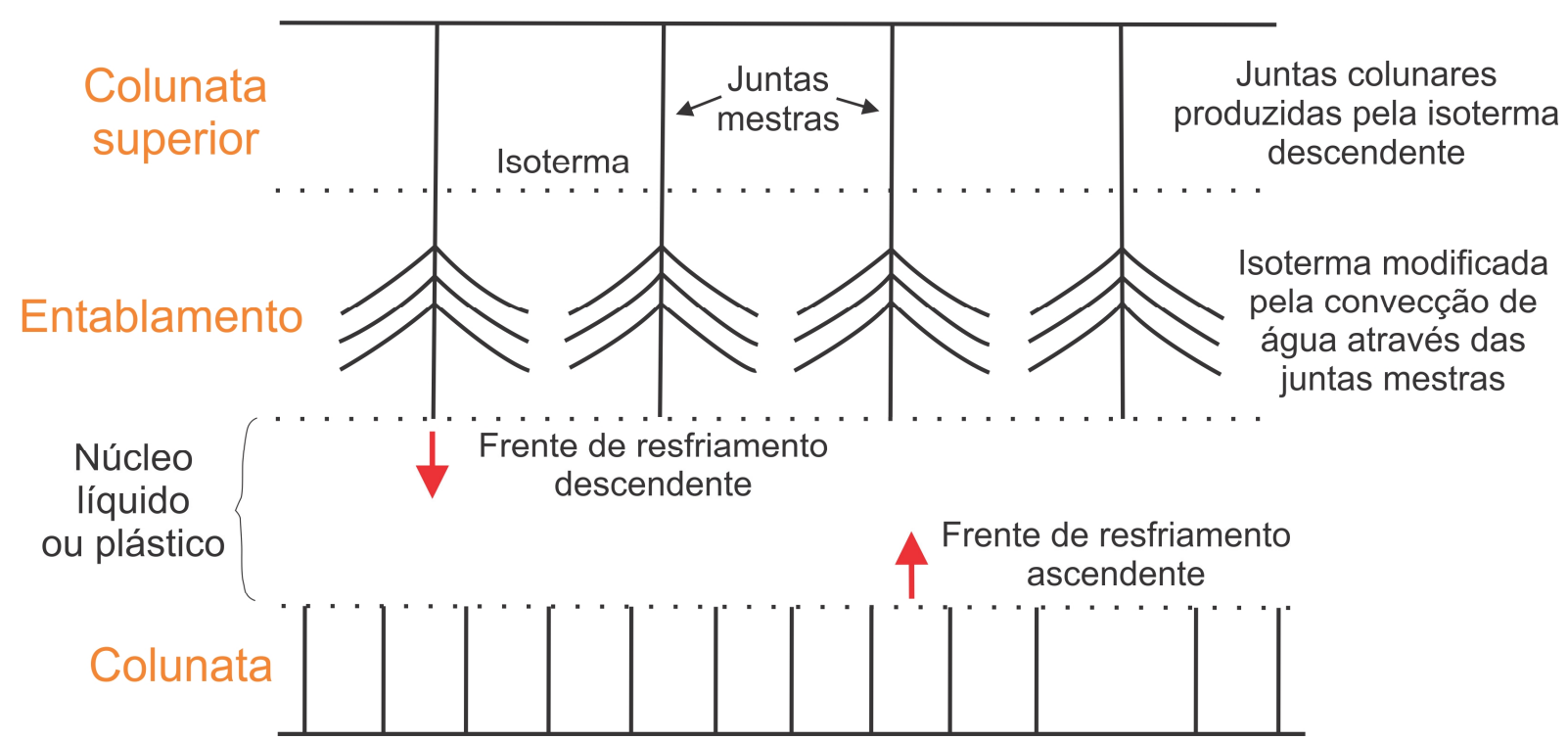

Figura 29: Modelo de formação de juntas colunares de derrames basálticos, com o desenvolvimento do nível de colunata superior e entablamento ao longo da frente de resfriamento descendente, com interferência de circulação de água através das juntas mestras. As juntas colunares mais regulares são formadas pela frente de resfriamento ascendente. Adaptado de Lyle (2000). 
Grandes descontinuidades sub-horizontais formadas por juntas laminadas pouco persistentes são normalmente encontradas no contato entre os níveis de colunata e entablamento em derrames tipo II e III, ou interceptando disjunções colunares (Long \& Wood 1986, Bondre et al. 2004a, b) (figura 30). Essas descontinuidades correspondem a fraturas sub-horizontais de grande continuidade lateral, formadas dentro do quadro tardi-magmático, ou seja, quando o derrame se encontra estagnado e em processo de resfriamento (Guidicini 1979, Moller \& Cabrera 1976, Fernandes et al. 2008 e 2010b). As principais características observadas nas fraturas sub-horizontais de grande continuidade lateral tardi-magmáticas consistem na nítida disposição paralela ao topo e base do derrame e, na relação morfológica com as disjunções colunares de resfriamento, formando ângulos de aproximadamente $90^{\circ}$ entre elas, mesmo quando as fraturas sub-horizontais se encontram onduladas (Guidicini 1979).

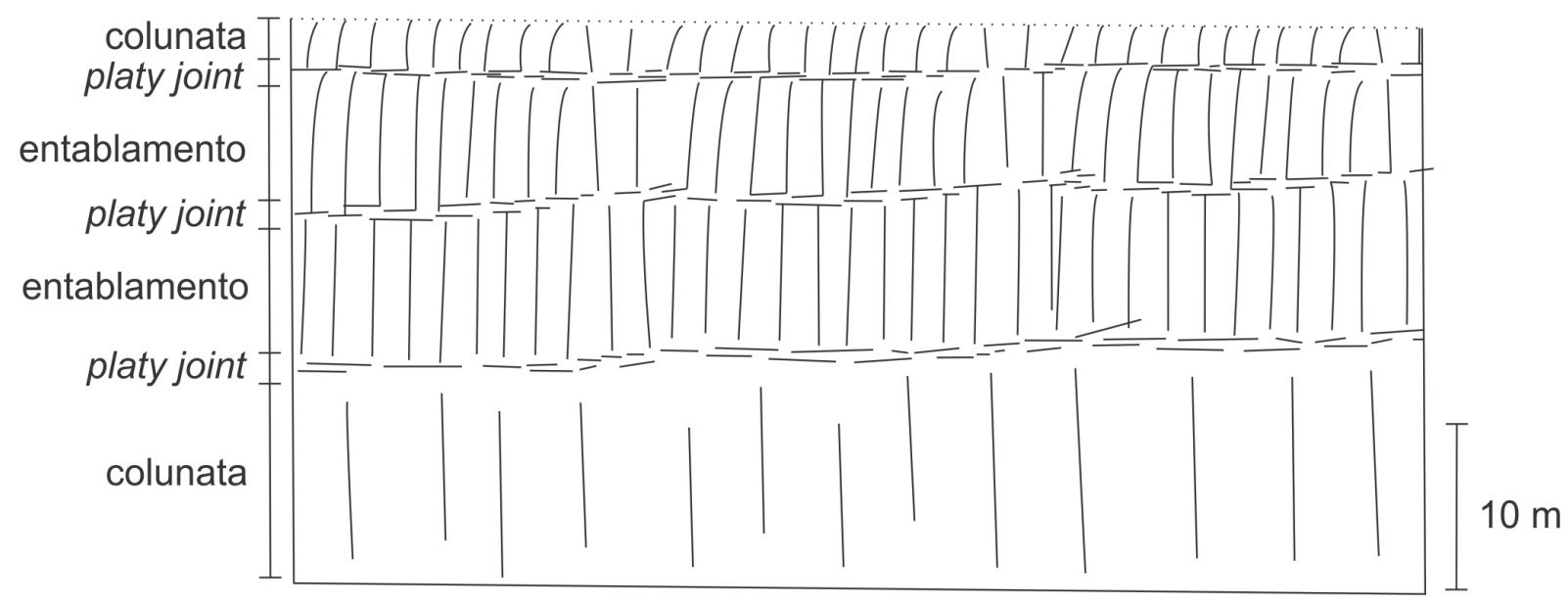

Figura 30: Esboço de um derrame tipo II da Província Basáltica de Deccan, mostrando padrão acamadado (multi-tiered) de juntas colunares, separadas por juntas horizontais (platy joints). Adaptado de Bondre et al. (2004a).

Neste contexto, fraturas sub-horizontais de grande continuidade lateral podem representar limites de solidificação do derrame, originadas pelo encontro das isotermas de resfriamento que migram das periferias em direção ao centro do derrame (Guidicini 1979). A formação de juntas sub-horizontais no contato entre os diferentes níveis de disjunções colunares (colunata e entablamento) não é uma regra; no entanto, são frequentes os relatos 
dessas descontinuidades (Guidicini 1979, Moller \& Souza Pinto 1976, Fernandes et al. 2008, 2010b).

Guidicini (1979) observou que simples juntas sub-horizontais de grande continuidade lateral associadas ao processo de resfriamento da lava poderiam ocorrer em diferentes partes do derrame. Dessa forma, pode-se admitir que, após o término da movimentação do derrame, a consolidação ocorrerá através das frentes de resfriamento ascendentes e descendentes. Fraturas sub-horizontais ligadas a esse processo poderão ocorrer como simples juntas de grande continuidade lateral, formadas durante o avanço das frentes de resfriamento em direção ao centro do derrame, ou como um horizonte fraturado de grande continuidade lateral definido por pequenas juntas, formado quando as duas frentes de resfriamento se encontram no núcleo do derrame. A presença de água superficial logo após o extravasamento do derrame irá causar perturbações nas frentes de resfriamento (Gomes 2001), o que poderá acarretar na formação de níveis colunata e entablamento irregulares dentro do derrame e, consequentemente, em descontinuidades sub-horizontais com ramificações e maior grau de ondulação.

A presença de materiais de preenchimento ao longo de "juntas-falhas" e juntas subhorizontais de grande continuidade lateral é relatada desde suas primeiras descrições (Guidicini \& Campos 1968, Oliveira 1969). Guidicini (1979) já havia destacado que esse material de preenchimento seria oriundo da percolação de soluções hidrotermais. No entanto, pouco se discutiu a respeito de um possível processo de fraturamento hidráulico e percolação de fluídos hidrotermais que tais estruturas poderiam sofrer. Fernandes et al. (2010b) descreveram o processo gerador e de preenchimento das fraturas sub-horizontais de grande continuidade lateral tardi-magmáticas presentes no contato entre os níveis colunata e entablamento nos derrames basálticos da Formação Serra Geral, Município de Ribeirão Preto (SP). Segundo esses autores, os fluídos hidrotermais migram das áreas de maior pressão para as áreas de menor pressão dentro do derrame, acumulando-se em bolsões ou ao longo das fraturas sub-horizontais preexistentes, podendo promover um fraturamento hidráulico nos locais em que se acumulam. 


\subsection{Processos pós-magmáticos}

Guidicini (1979) já discutira que as "juntas-falhas" correspondiam a juntas subhorizontais singenéticas ao resfriamento da lava (tardi-magmáticas), que teriam sofrido a ação de esforços posteriormente à consolidação da lava (pós-magmáticos), promovendo abertura e deslocamentos ao longo de descontinuidades preexistentes. A origem desses esforços foi associada a possíveis movimentações tectônicas regionais na bacia, como eventos de subsidência ou movimentações tectônicas ligadas à deriva continental.

As intensas investigações em locais de obras para construção de barragens constataram que fenômenos de alívio de tensões associado à erosão e ao entalhamento de vales fluviais também promoveriam a abertura e deslocamentos ao longo de descontinuidade preexistentes (Moller \& Cabrera 1976, Moller \& Souza Pinto 1976, Hasui et al. 1978, Cabrera \& Barbi 1981, Paes de Barros \& Guidicini 1981). As tensões virgens ou naturais correspondem ao produto de vários estados de tensões resultantes de eventos sucessivos na história geológica da rocha, e podem corresponder a esforços gravitacionais (tensão normal), tensões de origem tectônica, variação de energia térmica e processos físico-químicos (Mioto \& Coelho 1998). Quando a intensidade das tensões não é suficiente para produzir o fraturamento, ou mesmo quando o grau de confinamento é muito alto, as tensões ficam acumuladas nos maciços rochosos e poderão ser posteriormente liberadas naturalmente pela erosão ou artificialmente por escavação (Björnberg \& Meismith 1975). Na literatura, foram registrados relatos de deslocamentos de ordem decimétrica ao longo de estruturas subhorizontais, como "juntas-falhas", juntas de grande extensão lateral e contatos entre derrames, ocorridos durante a escavação de obras para a construção de hidroelétricas (Brito 1971, Nieble et al. 1974a, Nieble 1983). Apesar da possibilidade de deslocamentos ocorrerem pelo próprio processo de desmonte da rocha durante as escavações (tensões induzidas), este fenômeno também foi associado à liberação de tensões residuais (virgens, naturais) armazenadas nos maciços basálticos (Brito 1971, Nieble et al. 1974a, Nieble 1983).

A ocorrência de zonas de cisalhamento conjugadas no leito de rios foi atribuída por Paes de Barros \& Guidicini (1981) ao alívio de tensões residuais compressivas de origem tectônica em decorrência da formação de vales fluviais. A existência de tensões compressivas horizontais superiores às verticais (tensões normais, esforços gravitacionais), em locais de obras de construções de barragens sobre os derrames basálticos da Bacia do Paraná, foi 
inicialmente verificada por Midea \& Cury Jr. (1975) e observada posteriormente por outros autores em diferentes locais (e.g. Nieble 1983, Infanti Jr. et al. 1999). Os métodos de determinação de tensões podem valer-se de indicadores geológicos e sismológicos (qualitativos) ou mediante o emprego de equipamentos de medidas de deformações e pressões in situ (quantitativos). Midea \& Cury Jr. (1975) determinaram o estado de tensão interna do maciço rochoso no local da barragem de Ilha Solteira (SP-MS) pelo método de "sobrefuração" (overcoring). Este método é um dos mais usuais e baseia-se na determinação das deformações em paredes do furo. Em resumo, a tensão liberada pela "sobrefuração" ativa o equipamento de medida, obtendo-se diretamente os componentes do tensor de tensões (Midea \& Cury Jr. 1975, Mioto \& Coelho 1998). A origem dessas tensões foi atribuída a possíveis tensões térmicas de resfriamento da lava, desníveis topográficos e tensões residuais de origem tectônica (Midea \& Cury Jr. 1975).

Björnberg \& Kutner (1983) denominaram as zonas de cisalhamento conjugadas no leito de rios como "juntas-falhas em bigode" e associaram sua gênese a eventos transcorrentes posteriores ao magmatismo basáltico da Formação Serra Geral. As fraturas sub-horizontais de grande continuidade lateral, com feições de deslocamento relacionadas a eventos pósmagmáticos, foram classificadas por Souza Jr. \& Campos (1987b) e Souza Jr. \& Campos (1990) como "falhas horizontais" ou "juntas-falhas" de origem secundária, respectivamente. Análises estruturais realizadas em locais de construção de barragens têm indicado feições de deslocamentos ao longo das fraturas sub-horizontais preexistentes com atitudes compatíveis com movimentações regionais transcorrentes (Serra Jr. et al. 1986, Marques et al. 1987, Magalhães et al. 1992).

\subsubsection{Alívio de tensões}

O mecanismo de alívio de tensões verticais pode ocorrer pelo processo natural de erosão ou pelo processo de escavação em obras de engenharia (Nichols Jr. 1980) (figura 31). Isso ocorre devido à baixa magnitude da tensão principal mínima $(\sigma 3)$ vertical, representada pela coluna de rocha erodida (Hasui et al. 1978, Marques Filho \& Levis 1981). O processo de alívio de carga vertical (tensão normal) pela erosão pode promover a abertura de juntas preexistentes e a geração de juntas de alívio próximas à superfície, permitindo a alteração química ao longo dessas estruturas pelo intemperismo (Moler \& Cabrera 1976, Moler \& 
Souza Pinto 1976, Hasui et al. 1978, Cabrera \& Barbi 1981, Paes de Barros \& Guidicini 1981).
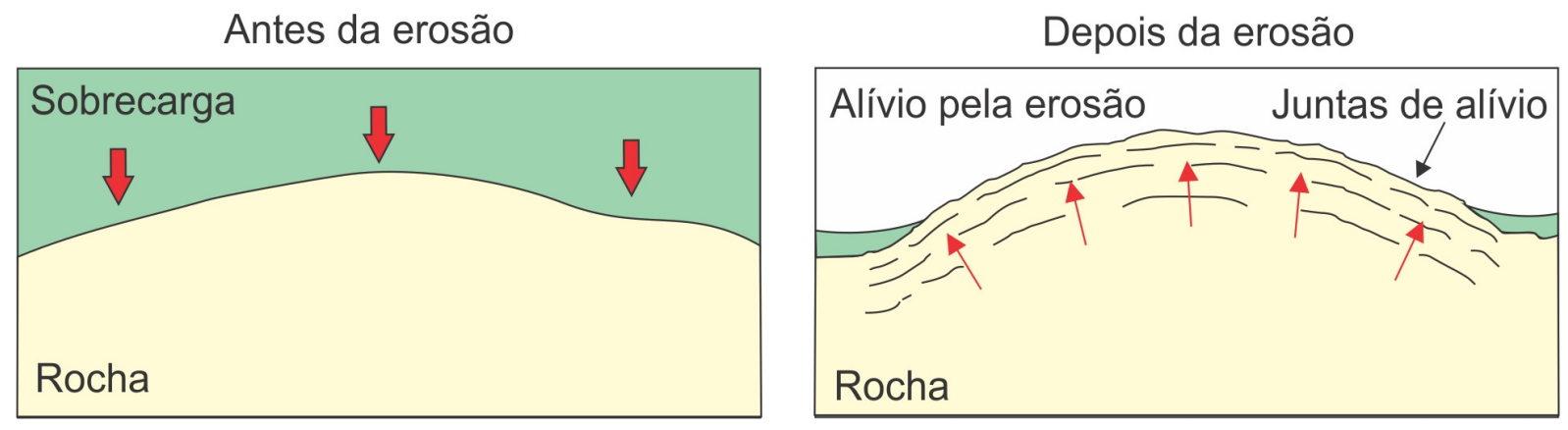

Figura 31: Formação de juntas de alívio em consequência do alívio de pressão pela erosão do material sobreposto.

Em vales fluviais, a erosão promove o alívio das tensões verticais (normais) e horizontais do maciço. O processo de alívio gera mudanças no campo de tensões locais, que resultam em modificações das relações das tensões principais ( $\sigma 1$ e $\sigma 3)$, possivelmente próximas aos valores críticos de cisalhamento e de distensão da rocha (Nichols Jr. 1980). Segundo Patton \& Hendron (1974), em ambientes de rochas sedimentares e brandas o processo de erosão em vales fluviais pode acarretar em deslocamentos das paredes do vale, arqueamento e cisalhamento abaixo do leito do rio (figura 32). Esses deslocamentos ocorrem com a geração de zonas de cisalhamento preferencialmente ao longo de estratos sedimentares sub-horizontais. Os deslocamentos sob o campo de tensões gravitacionais consistem de escorregamentos de solo ou rocha, cujo centro de gravidade se desloca para baixo e para fora do talude, condicionando a ruptura por cisalhamento (Infanti Jr. \& Fornasari Filho 1998). O fenômeno de alívio de tensões em vales formados em ambientes de rochas sedimentares acamadadas é amplamente reconhecido e aceito (Hamel 2001). O fenômeno de arqueamento no leito do rio é conhecido como rebound (Matheson \& Thomson 1973, Nichols Jr. 1980), ocasionado pela remoção ou relaxamento de cargas superpostas, no qual são geradas fraturas de alívio paralelas a superfície, acompanhadas também de zonas de cisalhamento. 


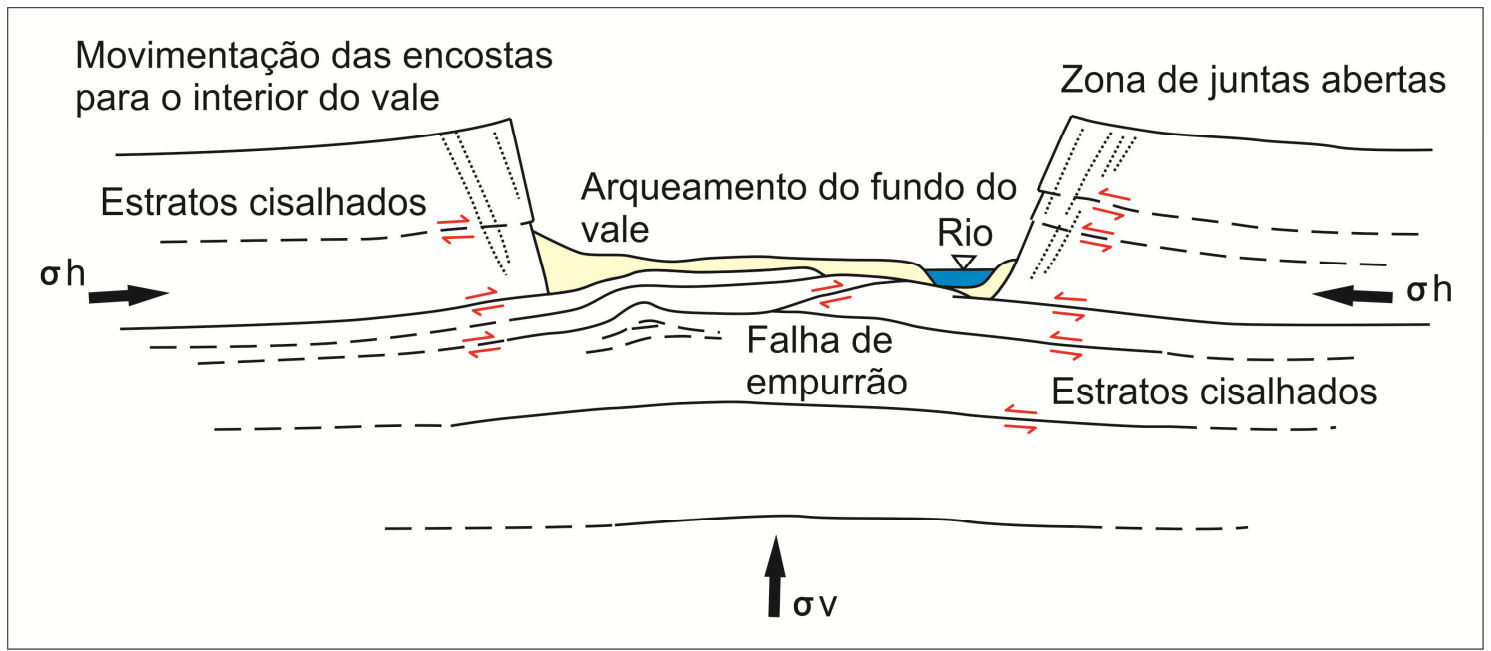

Figura 32: Feições estruturais relacionadas ao alívio de tensões em vales sobre rochas brandas e estratificadas. Adaptado de Patton \& Hendron (1974).

Em maciços rochosos, o ângulo de atrito e a coesão são parâmetros determinantes da resistência ao cisalhamento da rocha. Moller \& Souza Pinto (1976) constataram que a presença de material de preenchimento de juntas sub-horizontais de grande continuidade lateral em derrames basálticos promove o decréscimo do ângulo de atrito da estrutura. Porém, quando adicionado o efeito das irregularidades da junta em diferentes ordens de grandeza, o valor do ângulo de atrito eleva-se para mais do que o dobro. Feições de deslocamentos sobre descontinuidades sub-horizontais devido ao alívio lateral de tensões em vales foram discutidas em diversas ocasiões. Paes de Barros \& Guidicini (1981) discutem a ocorrência de sinais de movimentação relativa ao longo de descontinuidade sub-horizontais de grande extensão lateral, no qual a porção sobreposta à descontinuidade converge para o centro do vale, com deslocamentos de ordem decimétrica. Souza Jr. \& Campos (1987b) consideraram a movimentação ao longo de juntas e falhas horizontais primárias devido ao desconfinamento lateral em vales como uma das possíveis origens de falhas horizontais secundárias.

Zonas de cisalhamento conjugadas abaixo do leito do rio foram reconhecidas nos locais das barragens de Foz de Areia (PR) (Marques Filho \& Levis 1981) e Itaipu (PR) (Paes de Barros \& Guidicini 1981, Cabrera \& Barbi 1981). Marques Filho \& Levis (1981) abordaram o processo de alívio de tensões em vales fluviais sobre maciços basálticos e argumentaram que, com a rápida erosão do vale, as cargas verticais diminuiriam e as tensões horizontais passariam então a atuar como tensões maiores e tenderiam a descomprimir. Em 
vales mais largos e de fundo plano existiria uma tendência de abertura de fraturas subhorizontais por descompressão; já em vales profundos as tensões horizontais provocariam a ruptura por cisalhamento das camadas mais resistentes no leito do rio, criando horizontes de rocha fraturada.

Paes de Barros \& Guidicini (1981), com base no conceito de alívio de tensões em vales fluviais (Patton \& Hendron 1974), discutiram a gênese das zonas de cisalhamento encontradas abaixo de leito do rio no local da barragem de Itaipu, denominadas de "falhas em bigode" (figura 33). Para estes autores, com o aumento da pressão horizontal na camada de basalto no leito do rio, devido à configuração do vale, a rocha sofreria um possível arqueamento com a geração de uma zona de cisalhamento conjugada com movimentação de falha de empurrão abaixo do leito do rio. Os autores questionam se apenas o processo de erosão do vale seria capaz de promover deslocamentos decimétricos e a ruptura do basalto maciço, já que deve ser considerada a maior competência do basalto maciço quando comparado às rochas sedimentares e brandas. Dessa forma, Paes de Barros \& Guidicini (1981) sugerem a existência de esforços compressivos horizontais de origem tectônica no maciço, que seriam liberados com a erosão do vale. No entanto, os autores colocam em dúvida se tensões tectônicas permaneceriam residuais no maciço e se, ao serem liberadas pela erosão, poderiam gerar as zonas de cisalhamento observadas.

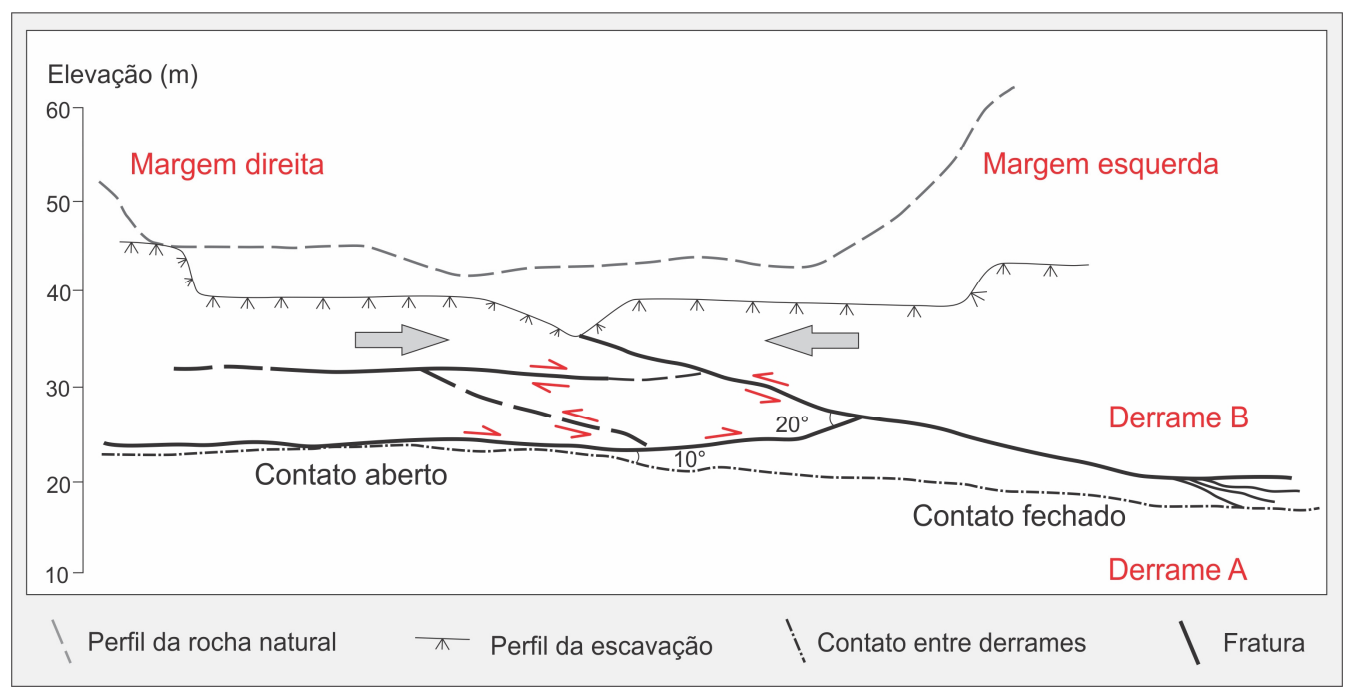

Figura 33: Seção geológica esquemática do talvegue do Rio Paraná, no local da barragem de Itaipu, ilustrando a estrutura conjugada denominada de "falha em bigode" (Paes de Barros \& Guidicini 1981). 
Os trabalhos que discutiram a origem de movimentos cisalhantes ao longo das "juntasfalhas”, posteriores a Paes de Barros \& Guidicini (1981), passaram a considerar a atuação direta de esforços tectônicos regionais sobre essas estruturas. A seguir serão apresentados os modelos e os possíveis eventos tectônicos causadores da movimentação ao longo das "juntasfalhas".

\subsubsection{Esforços tectônicos}

A instalação da Bacia Bauru sobre a porção mais espessa das rochas basálticas sugere, nessa região, a influência da subsidência termal na geração dessa bacia, bem como da subsidência flexural devido à sobrecarga exercida pelo grande volume de rochas basálticas (Riccomini 1995, 1997a, Milani \& Ramos 1998). No Neocretáceo, importantes atividades tectônicas relacionadas a manifestações alcalinas com formação de áreas soerguidas tiveram grande influência na sedimentação desta bacia (Riccomini 1995, Fernandes \& Coimbra 1996). Segundo Bartorelli (1997), as numerosas cachoeiras e saltos localizados na área da Bacia Hidrográfica do Paraná representam indícios de atividade neotectônica, manifestada pela reativação de estruturas do embasamento de expressão regional. No Cenozóico, o tectonismo deformador da Bacia Bauru é reconhecido por registros de deslocamentos transcorrentes correlacionados a importantes alinhamentos estruturais (Riccomini 1995, 1997a), com provável atividade neotectônica durante o quaternário (Riccomini 1997b).

As evidências de atividades tectônicas após o magmatismo da Formação Serra Geral contribuíram para a elaboração de modelos tectônicos associados à geração das "juntasfalha”. Inicialmente, Paes de Barros \& Guidicini (1981) sugeriam que possíveis tensões tectônicas residuais no maciço, quando liberadas pela erosão do vale, gerariam zonas de cisalhamento sub-horizontais. Os trabalhos que se seguiram passaram a associar a gênese e deformação das fraturas sub-horizontais de grande continuidade lateral a eventos tectônicos da bacia, como movimentações transcorrentes (Björnberg \& Kutner 1983, Serra Jr. et al. 1986, Marques et al. 1987), subsidência (Souza Jr. \& Campos 1987a, b) e soerguimentos (Infanti Jr. 1987) (quadro 2). 
Quadro 2: Hipóteses de gênese e deformação de fraturas sub-horizontais de grande continuidade lateral pós-magmáticas, associadas a eventos tectônicos.

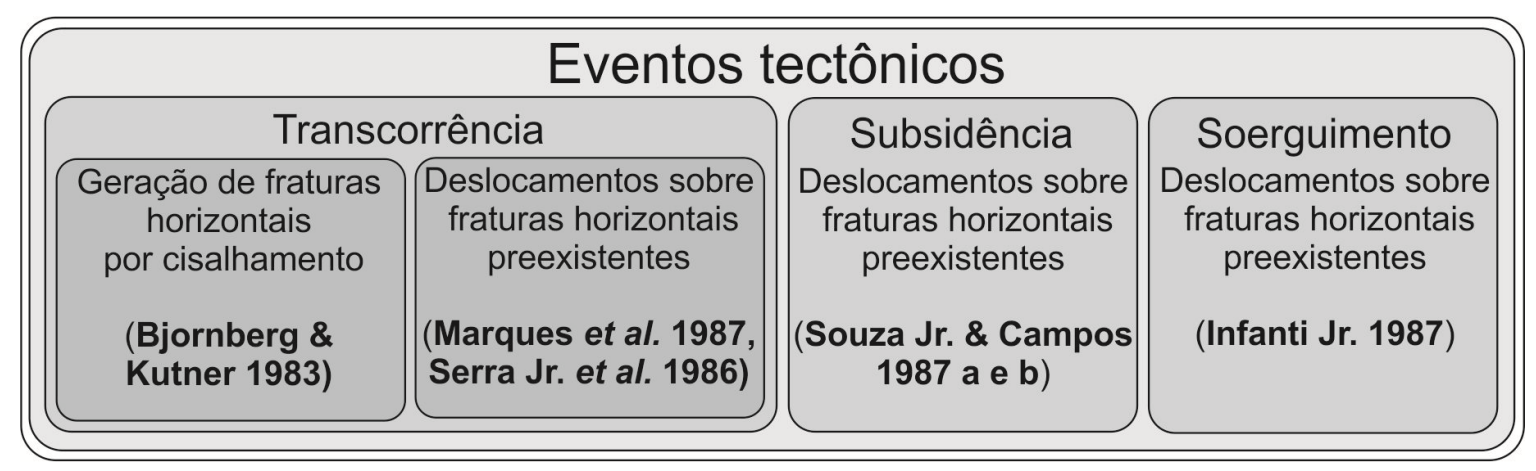

O modelo de Björnberg \& Kutner (1983) considera que movimentações transcorrentes pela reativação de importantes falhas preexistentes na bacia poderiam gerar falhas subhorizontais próximo à superfície (figura 34). Os autores argumentam que sob um regime transcorrente, o esforço vertical decorrente do peso do maciço pode ser aliviado próximo a superfície, condicionando a formação das "juntas-falhas". Dessa forma, o padrão de fraturas sub-horizontais varia com o aumento das tensões com a profundidade. Próximo a superfície, ocorreriam "juntas-falhas" preferencialmente em zonas de menor resistência, como contatos litológicos e zonas previamente fraturadas. Em maiores profundidades as estruturas ocorreriam em litologias mais resistentes, como basalto maciço, com fraturas ramificadas na forma de "junta-falha em bigode". Em estados mais elevados de tensão vertical ocorreria um microfraturamento do maciço (figura 35). Os autores também consideram que reativações de eventos compressivos durante o processo de erosão do vale causariam uma sobreposição de feições sub-horizontais (figura 35). 


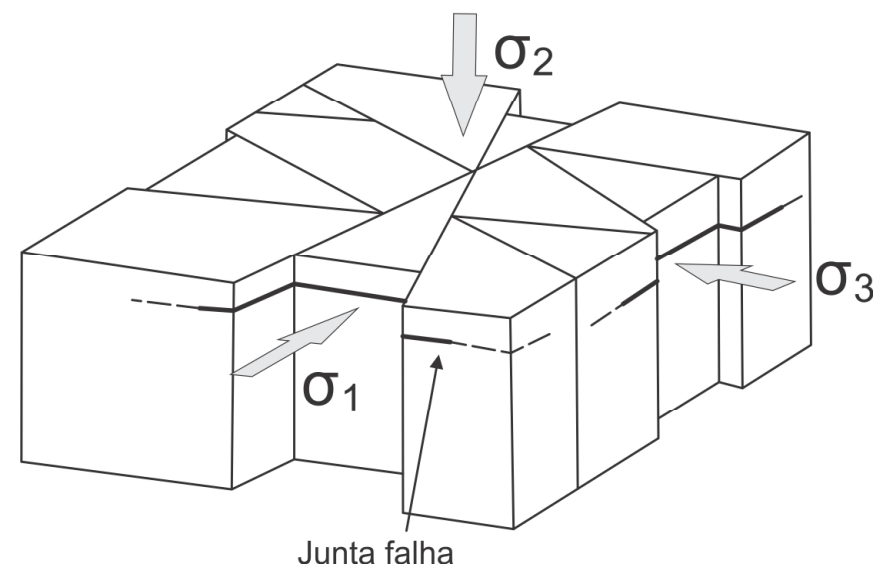

Figura 34: Modelo tectônico transcorrente para a formação das "juntas-falhas" proposto por Björnberg \& Kutner (1983). Condições de esforços $\sigma 1>\sigma 2>\sigma 3$. Este modelo considera que fraturas de cisalhamento perpendiculares a $\sigma 2$ seriam geradas devido ao baixo esforço vertical pela proximidade da superfície.

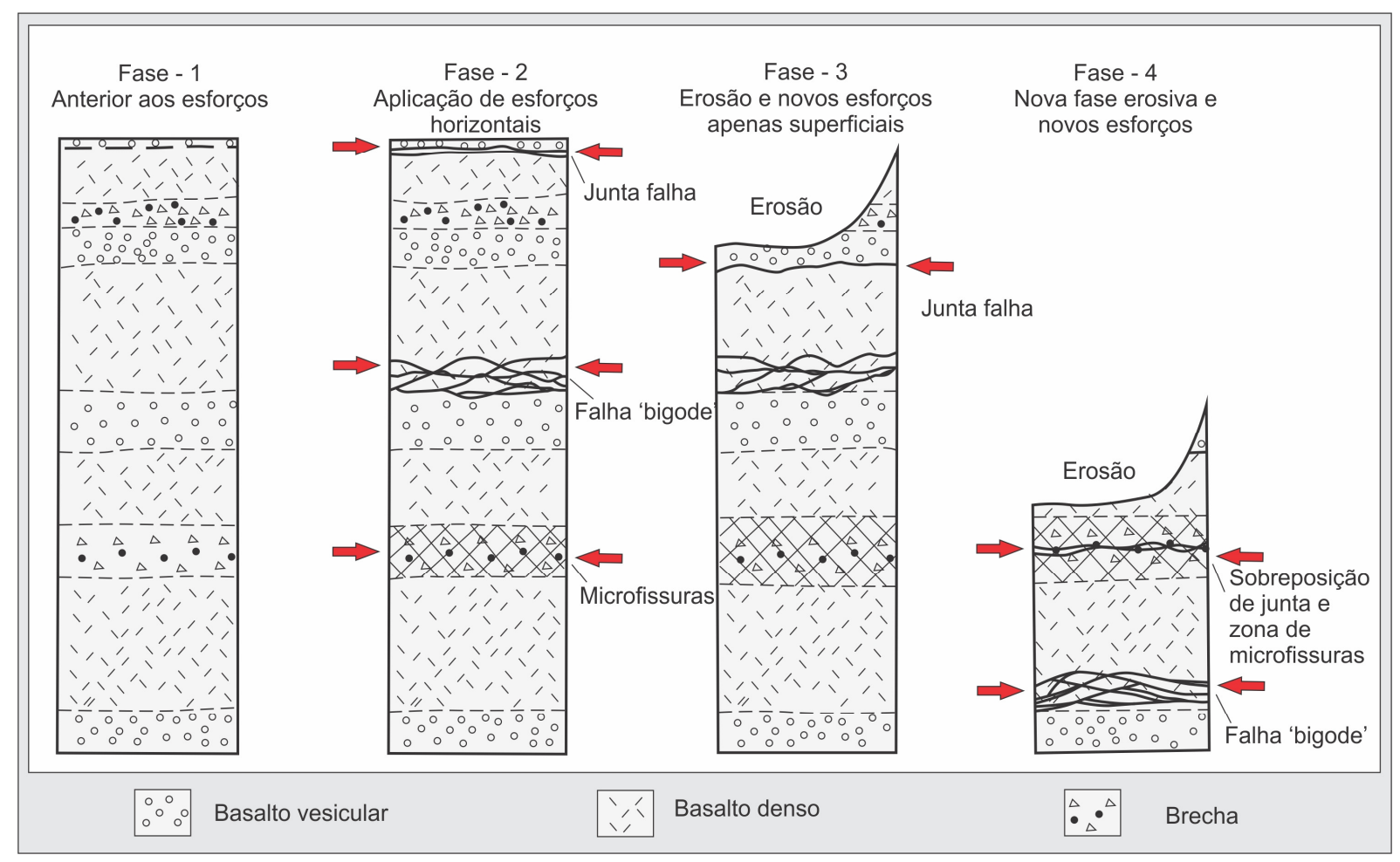

Figura 35: Modelo da gênese de "juntas-falhas" devido a esforços transcorrentes na Bacia do Paraná, desenvolvido por Björnberg \& Kutner (1983). Próximo a superfície, ocorreriam "juntas-falhas" preferencialmente em zonas de menor resistência, como contatos litológicos e zonas previamente fraturadas. Em maiores profundidades as estruturas ocorreriam em litologias mais resistentes, como basalto maciço, na forma de "junta-falha em bigode". Em estados mais elevados de tensão vertical ocorreria um microfraturamento do maciço. A 
repetição de vários eventos compressivos contemporâneos ao processo erosivo condicionaria a sobreposição de feições.

O modelo apresentado por Björnberg \& Kutner (1983) apresenta pontos questionáveis, já que não há registros de reativações constantes de eventos tectônicos compressivos durante a formação dos vales atuais sobre a Bacia do Paraná. Além disso, sob um regime de esforços compressivos, a geração de fraturas de cisalhamento apresenta uma relação angular com esforço máximo $\sigma 1$. Dessa forma, as "juntas-falhas em bigode”, ou "falhas em bigode", as quais apresentam um padrão conjugado com deslocamento inverso (figura 22), poderiam ser geradas durante a movimentação transcorrente. Sob um regime transcorrente, as deformações associadas ao cisalhamento podem se expressar como estruturas compressivas, como dobras e falhas inversas, perpendicularmente à direção do esforço principal máximo (figura 36). A reativação de estruturas preexistentes de baixa inclinação como falhas inversas também é plausível, desde que tais estruturas possuam orientações que viabilizem o deslocamento (figura 36).
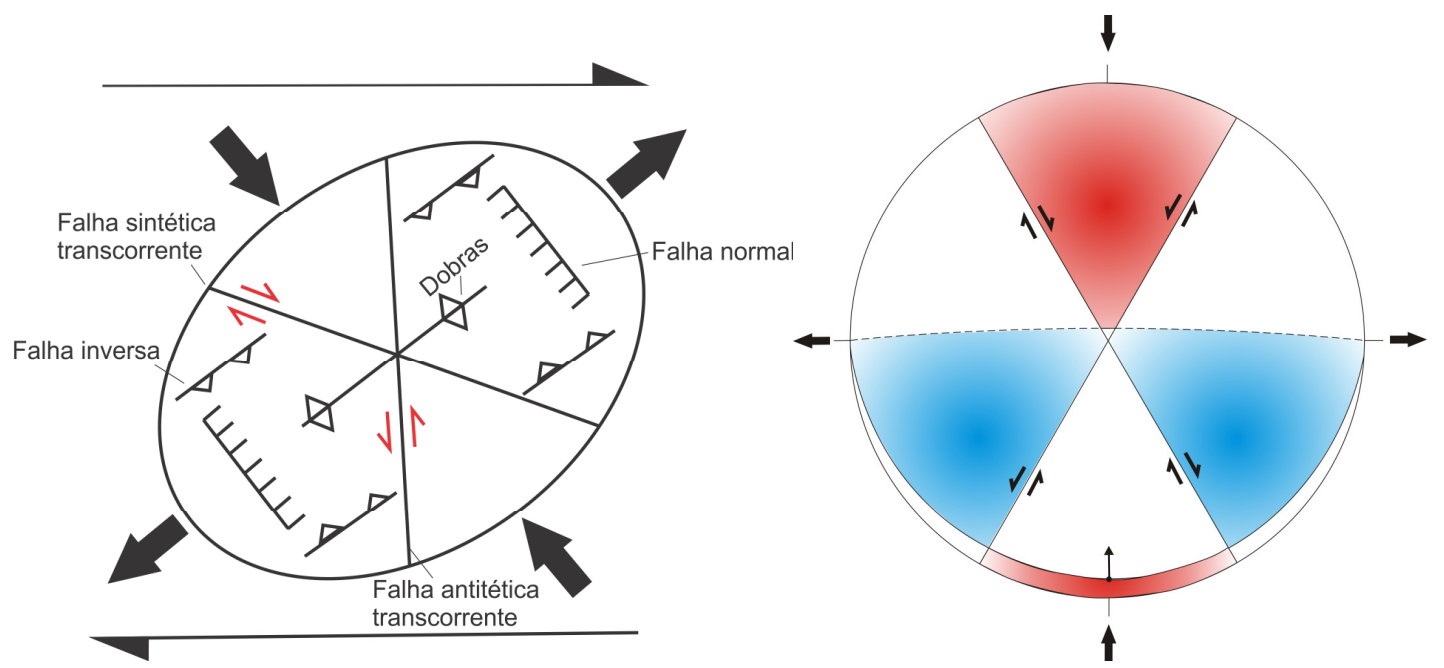

Figura 36: Elipsóide de deformação com a representação da relação angular entre as estruturas e a direção de esforços associadas a uma zona de cisalhamento dextral (baseado em Harding 1974) (esquerda). Projeção estereográfica exemplificando duas falhas direcionais subverticais e uma falha inversa de baixo ângulo, em que os esforços compressivos e distensivos se encontram na posição horizontal (direita). Com a determinação de campos de encurtamento (vermelho) e de estiramento (azul), pelo método dos diedros retos de Angelier (1994), identifica-se a coerência entre os domínios compressivos e distensivos que viabilizam os deslocamentos. 
Serra Jr. et al. (1986) atribuíram a esforços tectônicos os deslocamentos centimétricos observados ao longo de descontinuidades preexistentes no local da barragem de Taquaruçu (SP). Estrias de atrito observadas localmente em algumas fraturas sub-horizontais de um extenso horizonte fraturado apresentavam indícios de movimentação inversa, condizente com a movimentação observada no contato entre derrames (mergulho de $13^{\circ}$ ). Serra Jr. et al. (1986) concluíram através de determinações gráficas que, tanto as estrias das fraturas verticais, quanto as estrias das fraturas sub-horizontais, estavam relacionadas ao mesmo regime transcorrente.

Uma situação semelhante foi constatada no local da barragem de Porto Primavera (SPMS). Marques et al. (1987) e Magalhães et al. (1992) apontam para a vigência de um regime transcorrente, que teria afetado tanto os basaltos quanto as rochas sedimentares posteriores (Grupo Caiuá, Bacia Bauru). A baixa intensidade da movimentação tectônica teria apenas deslocado centimetricamente fraturas preexistentes. Através da determinação de direção de esforços pelo método dos diedros retos, Magalhães (1999) concluiu que fraturas de baixa inclinação presentes neste local apresentavam indícios de movimentação inversa, evidenciados pelas estrias de fricção. Essa movimentação seria compatível com o regime transcorrente regional e estaria possivelmente associada a deformações locais transpressivas.

Souza Jr. \& Campos (1987a, b) consideraram que as falhas horizontais de origem secundária (pós-magmáticas) se formariam ao longo de descontinuidades preexistentes e poderiam estar associadas ao deslizamento flexural em decorrência da subsidência flexural da bacia; ou como anteriormente apontado por Paes de Barros \& Guidicini (1981), por movimentações decorrentes do processo erosivo, com o desconfinamento lateral das tensões residuais em vales. Souza Jr. \& Campos (1987a) discutem a origem de esforços compressivos em decorrência da subsidência da Bacia do Paraná segundo as considerações de Soares (1974), cujos esforços compressivos ocorreriam contemporaneamente ao vulcanismo basáltico e estariam orientados radialmente em relação à bacia.

Ao discutir a proposta de Souza Jr. \& Campos (1987a), Infanti Jr. (1987) argumenta que apesar da subsidência no interior da bacia, as tensões atuantes durante o magmatismo basáltico eram essencialmente trativas. Infanti Jr. (1987) propõe que o soerguimento da bacia relacionado ao episódio de intrusões alcalinas poderia causar movimentações ao longo de descontinuidades horizontais. Este autor considerou que durante o soerguimento ocorreu uma 
inversão das tensões principais e, neste momento, quando a inclinação da tensão principal maior superou o ângulo de atrito, poderiam ter ocorrido rupturas ao longo de superfícies horizontais. O posterior alívio de tensões horizontais pelo entalhamento fluvial realçaria as feições, sujeitas à percolação e intemperismo mais intensos. Além disso, Infanti Jr. (1987) destacou que o fenômeno de rebound também poderia estar relacionado aos cisalhamentos observados. Souza Jr. (1992) discutiu a ocorrência de uma zona de cisalhamento com ocorrência de falhas conjugadas ao longo do contato entre um derrame basáltico e o xisto do embasamento no local da barragem de Nova Ponte (MG). Essas feições apresentam sentido de deslocamento paralelo ao vale, descartando a possibilidade de associação com o alívio de tensões laterais pelo entalhamento fluvial. Tal deslocamento foi associado a possíveis esforços compressivos ocasionados pelo soerguimento do Arco do Alto Paranaíba ou pela reativação de antigas suturas do embasamento.

Os eventos de subsidência e soerguimento relacionados à instalação e formação da Bacia Bauru durante o Neocretáceo são amplamente reconhecidos (Riccomini 1995, 1997 , Fernandes \& Coimbra 1996, Milani \& Ramos 1998). Dessa forma, as associações de deslocamentos sobre descontinuidades sub-horizontais preexistentes a eventos de subsidência e soerguimento, tardiamente às manifestação magmáticas da Formação Serra Geral, necessitam de maiores investigações, já que as sugestões apresentadas por Souza Jr. \& Campos (1987a), Infanti Jr. (1987) e Souza Jr. (1992) não foram acompanhadas de levantamentos estruturais que pudessem comprovar essas hipóteses. Apesar de reconhecer a existência de importante atividade tectônica pós magmática da bacia, Hasui et al. (1978) consideraram que fraturas de baixo mergulho presentes em derrames basálticos estariam relacionadas apenas ao fluxo da lava, resfriamento e a alívio de carga pela erosão. No entanto, a compatibilidade entre deslocamentos inversos sobre descontinuidades sub-horizontais ou de baixo mergulho preexistentes e movimentos transcorrentes (Serra Jr. et al. 1986, Marques et al. 1987, Magalhães et al. 1992, Magalhães 1999) sugerem uma possível correlação com tectonismo deformador da Bacia Bauru. Segundo Riccomini (1997a), a deformação da Bacia Bauru, que sucedeu o preenchimento sedimentar, proporcionou a geração de estruturas como falhas e juntas resultantes de dois regimes trancorrentes, correlacionáveis a importantes alinhamentos estruturais, com provável atividade neotectônica durante o quaternário (Riccomini 1997b). 


\section{RECONHECIMENTO DE CAMPO}

A etapa de reconhecimento de campo foi realizada em diferentes afloramentos na área dos derrames basálticos da Formação Serra Geral, Bacia do Paraná. Os locais visitados estão indicados no mapa da figura 37, e correspondem a: Usina Hidrelétrica de Água Vermelha, localizada no Rio Grande entre os estados de São Paulo e Minas Gerais, municípios de Ouroeste (SP) e Iturama (MG); afloramento na Rodovia BR-277, próximo ao município de Laranjeiras do Sul (PR); e pedreira na região do município de Ribeirão Preto (SP). Nesta etapa do trabalho, foi realizado o reconhecimento dos estilos e levantamento de dados estruturais de fraturas sub-horizontais. Amostras de rocha e material de preenchimento das fraturas foram coletadas para caracterização mineralógica.

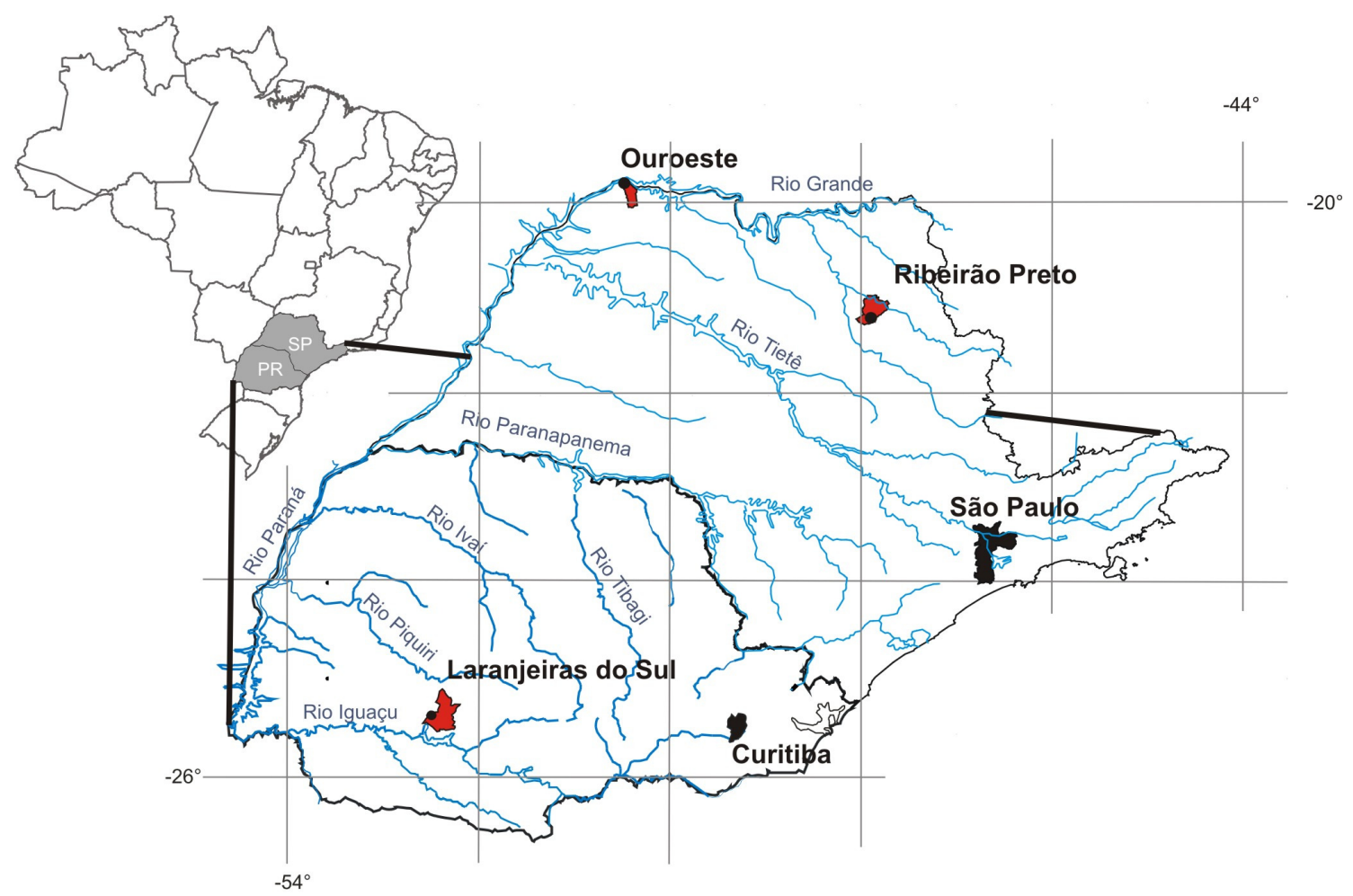

Figura 37: Mapa de localização dos locais visitados. 


\subsection{Usina Hidrelétrica de Água Vermelha (SP-MG)}

A Usina Hidrelétrica de Água Vermelha se localiza no Rio Grande, divisa dos estados de São Paulo e Minas Gerais, aproximadamente $80 \mathrm{~km}$ a montante da confluência com o Rio Paraná. A geologia local é definida por uma sucessão de derrames basálticos da Formação Serra Geral, capeados por arenitos da Formação Bauru. Na fase de investigação para a construção da usina foram descritos seis derrames basálticos na área de influência da fundação da barragem, os quais possuem comportamento sub-horizontal e espessura entre 10 a 44 metros. Os derrames apresentam a sucessão típica de derrames basálticos: brecha basáltica com mistura de arenito no topo, basalto vesículo-amigdaloidal nas zonas periféricas e basalto denso micro-cristalino no centro. Sobre os derrames basálticos ocorrem aluviões e colúviões recentes.

Feições anômalas no local da barragem de Água Vermelha compreendem as chamadas "estruturas circulares" e uma descontinuidade sub-horizontal bem desenvolvida, caracterizada como um horizonte fraturado e denominada como "junta-falha" (Moura Filho \& Sorregotte 1975, Midea et al. 1975, Ussami et al. 1976, Duó et al. 1983). Essas estruturas foram intensamente investigadas na época da construção da barragem por representarem feições com aspectos geomecânicos desfavoráveis.

As "estruturas circulares" apresentam diâmetro de centenas de metros, manifestam-se como depressões circulares e elípticas vistas em planta, ocorrem em meio ao derrame basáltico do leito do Rio Grande. As "estruturas circulares" são circundadas por diques de basalto compacto e seus interiores são constituídos por porções de basalto brechado com cimento calcítico, com horizontes de basalto maciço e vesículo-amigdaloidal de difícil correlação horizontal (Ussami et al. 1976, Araújo \& Hasui 1985). Essas estruturas foram interpretadas como condutos de extravasamento de lava tipo central por Araújo \& Hasui (1985). No entanto, trabalhos mais recentes sugerem que as "estruturas circulares", presentes no local da Usina de Água Vermelha possam na realidade representar estruturas de colapso, em vista da grande semelhança com outras estruturas descritas na América do Norte (Frank et al. 2008).

Uma descontinuidade sub-horizontal bem desenvolvida e de grande continuidade lateral ocorre 25 metros abaixo do leito do rio. Devido à importância dessa estrutura para a 
estabilidade das fundações, foi construído no local da barragem de Água Vermelha um túnel de prospecção ao longo do seu eixo, com 600 metros de comprimento e seção transversal de 5 $\mathrm{m}^{2}$, que intercepta grande parte da extensão dessa descontinuidade sub-horizontal (figura 38).

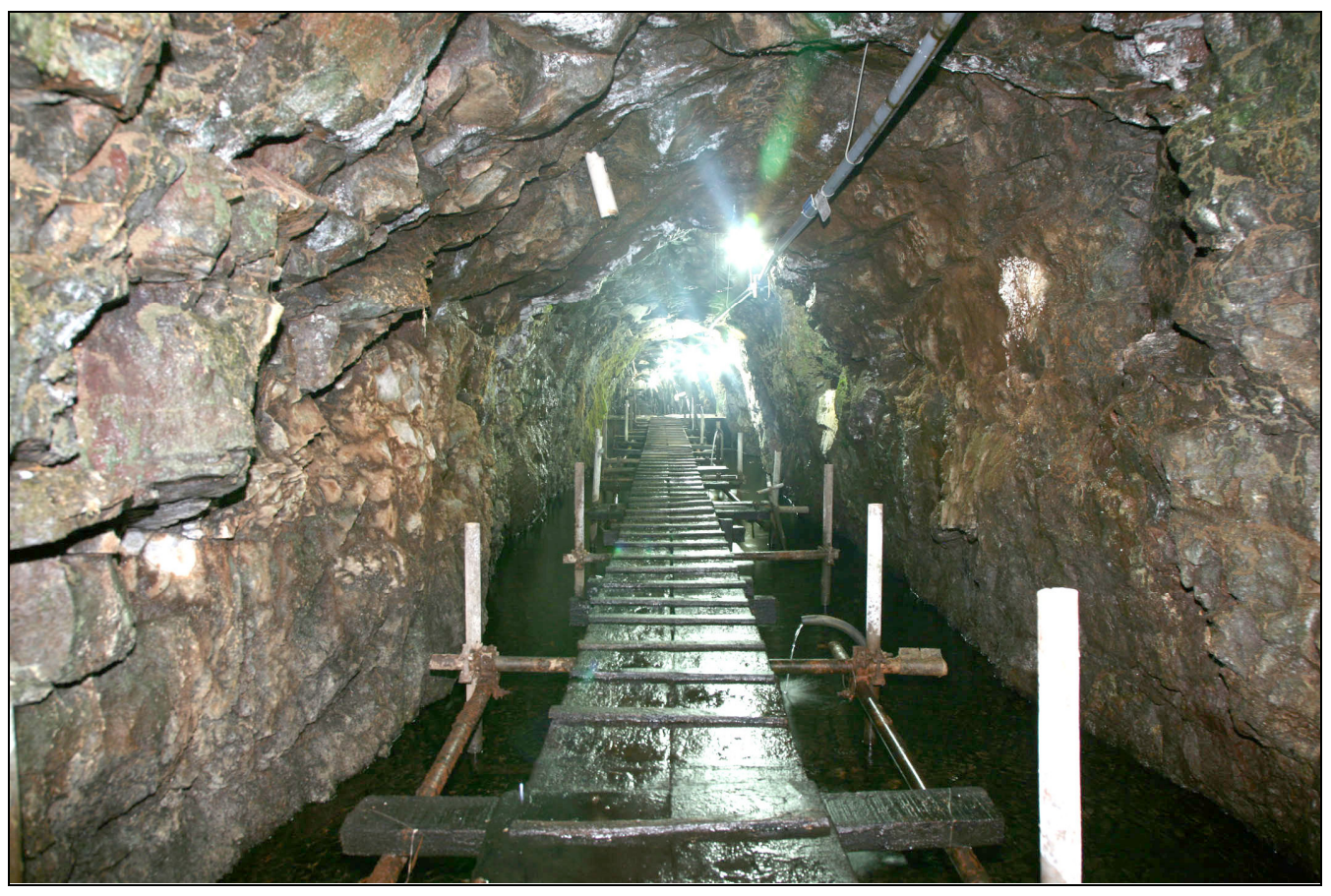

Figura 38: Túnel de prospecção ao longo do eixo da barragem, localizado a aproximadamente 20 metros a baixo do leito do rio. Usina Hidrelétrica de Água Vermelha (SP-MG) (foto de Francesco Barale).

A descontinuidade sub-horizontal é caracterizada como um horizonte fraturado de grande continuidade lateral. Este horizonte é concordante com a atitude geral dos derrames basálticos, ocorre na base do derrame aflorante no leito do Rio Grande e poucos metros acima do contato com o derrame subjacente (Figura 39). Tal estrutura apresenta persistência subhorizontal considerável, com ondulações e algumas irregularidades ao longo de sua extensão. Em campo foram coletados dados da atitude das fraturas que compõem o horizonte de grande continuidade lateral, os quais foram plotados em estereogramas (diagrama de SchmidtLambert, hemisfério inferior), empregando-se o programa computacional Stereo32, versão 1.0.2 (figura 40). As fraturas possuem atitude bastante dispersa, porém com duas direções preferenciais $\mathrm{N}-\mathrm{S}$ e NW-SE e mergulho médio de $17^{\circ}$ para $\mathrm{W}$ e $11^{\circ}$ para $\mathrm{SW}$. 


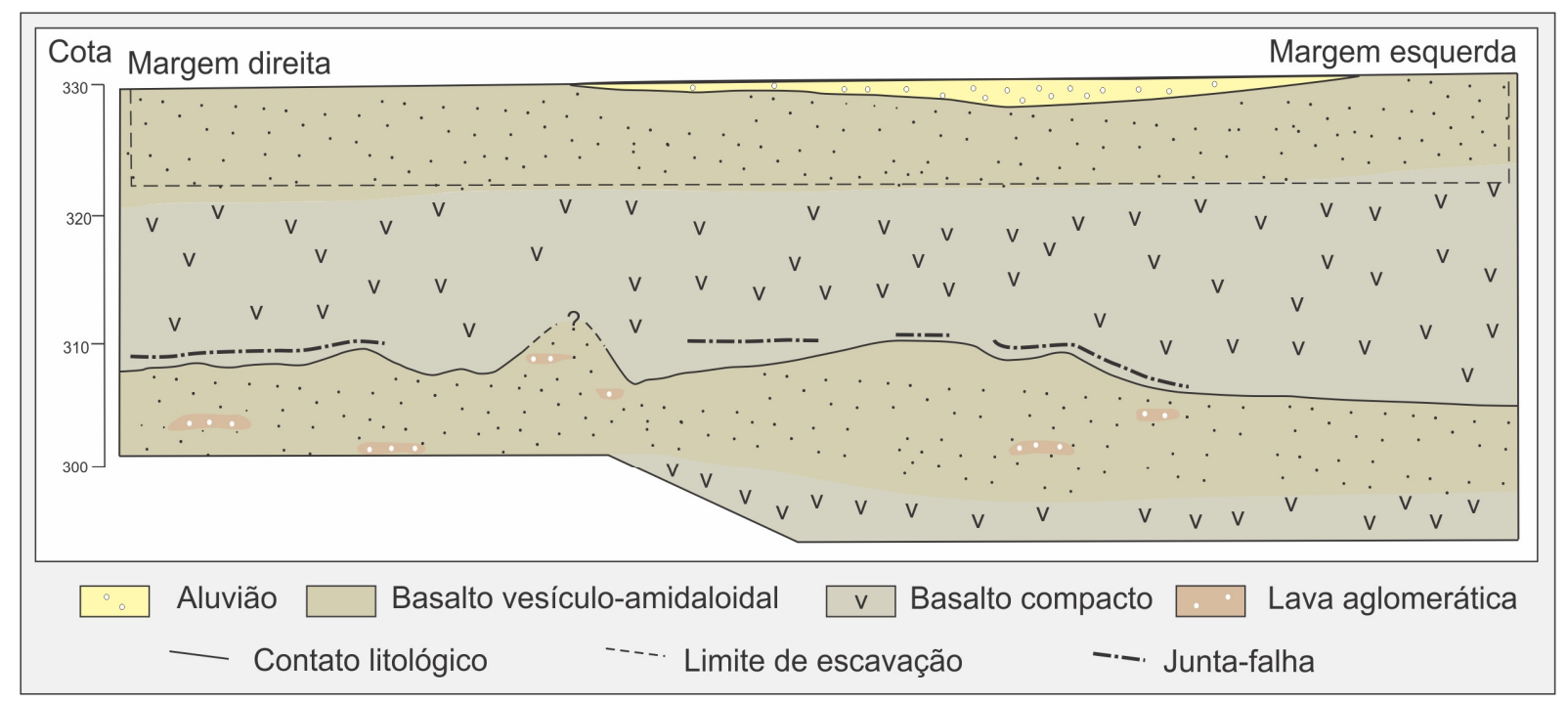

Figura 39: Seção geológica esquemática dos derrames basálticos no local da barragem de Água Vermelha (SP-MG). Adaptado de Ussami et al. (1976).
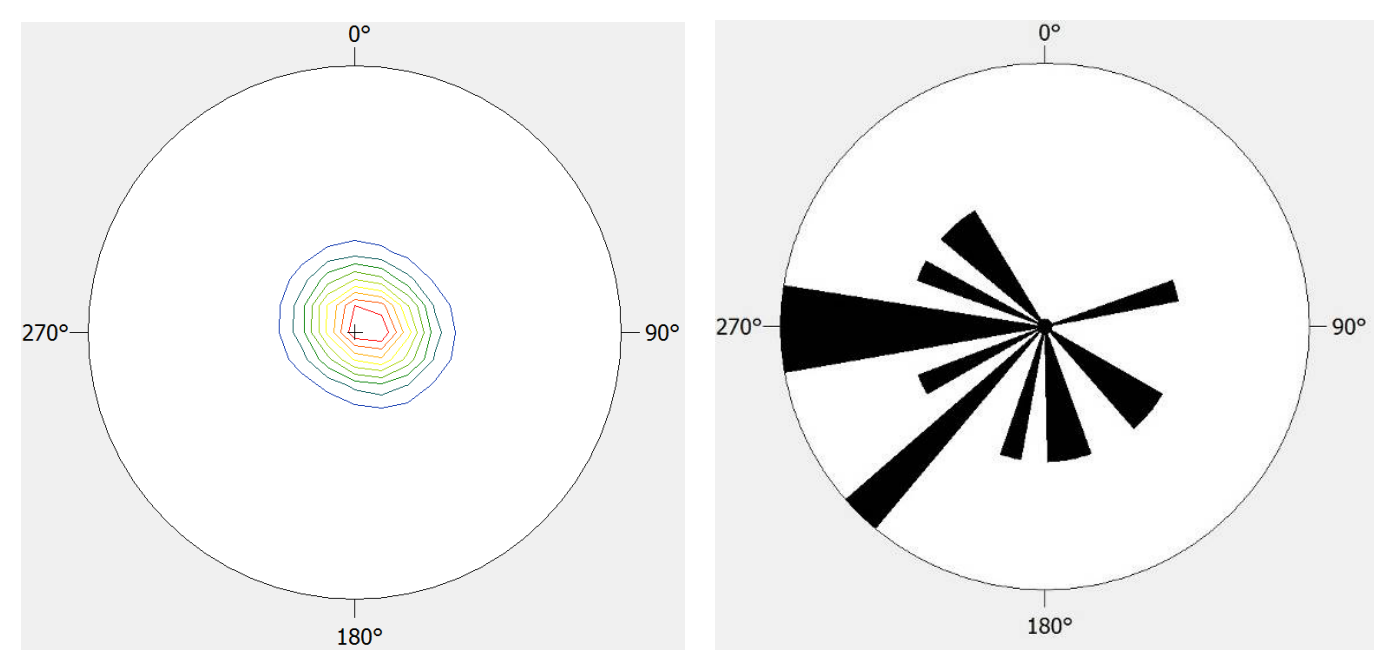

Figura 40: Estereograma representando a distribuição polar dos planos das fraturas que definem o horizonte fraturado (esquerda). Rosácea com a representação do sentido preferencial de mergulho das fraturas para W e SW (direita) (hemisfério inferior).

O horizonte fraturado apresenta uma variedade de características ao longo de sua extensão. A estrutura é caracterizada por um horizonte de aproximadamente 10 centímetros de espessura, definido por uma família de fraturas sub-horizontais e sub-paralelas, com espaçamento de 2 centímetros em média. Individualmente, as fraturas são pouco persistentes, planares e curviplanares, definindo blocos em forma de lentes (figura 41). Lateralmente, esta estrutura se transforma em um horizonte de quase 2 metros de espessura (figura 42), definido 
por uma família de fraturas de maior continuidade lateral e nitidamente planares, com espaçamento de 5 a 20 centímetros, em média (figura 43).

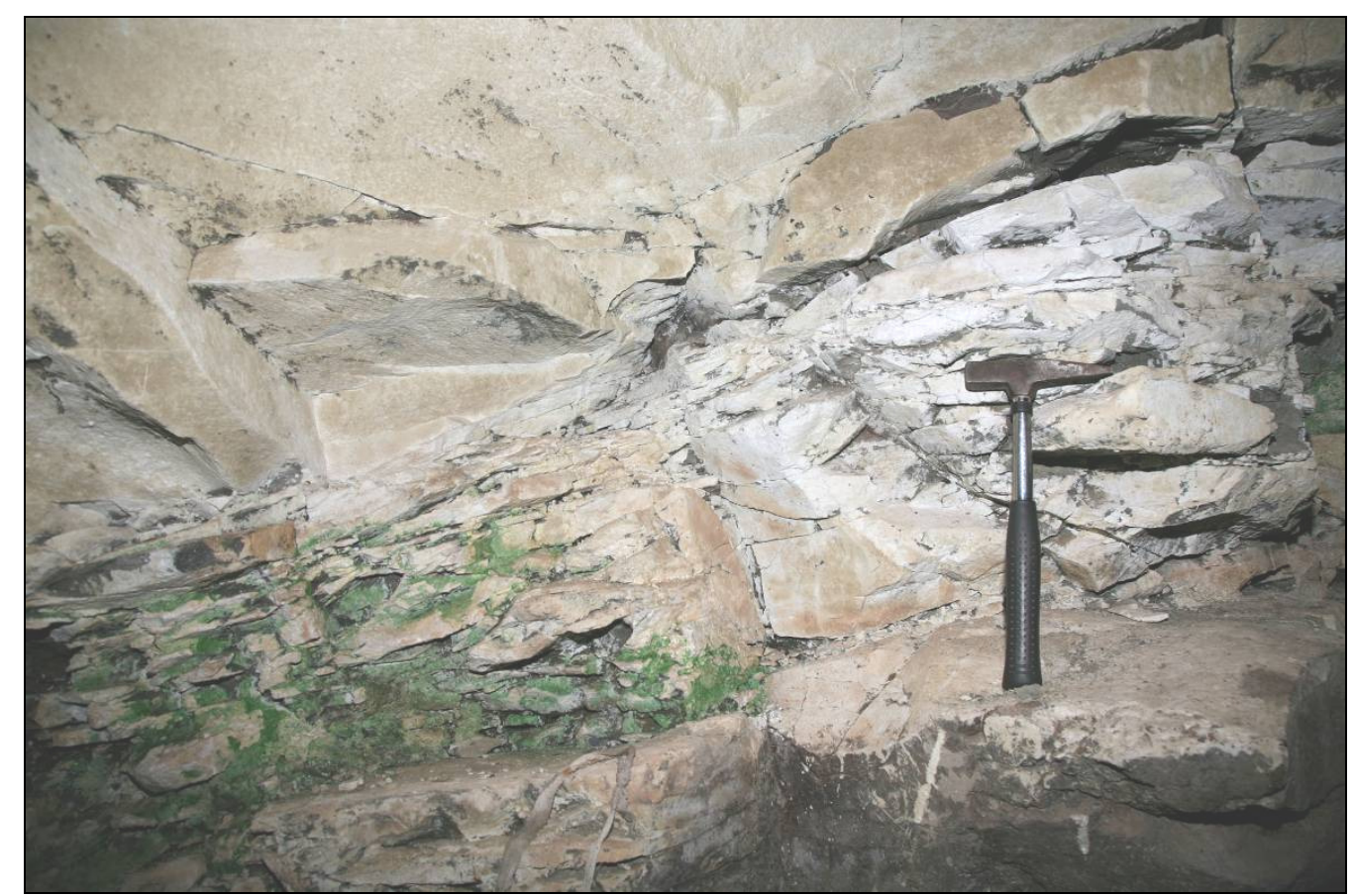

Figura 41: Horizonte fraturado com 10 a $40 \mathrm{~cm}$ de espessura, composto por fraturas subparalelas e em geral curviplanares, definindo blocos em forma de lentes.

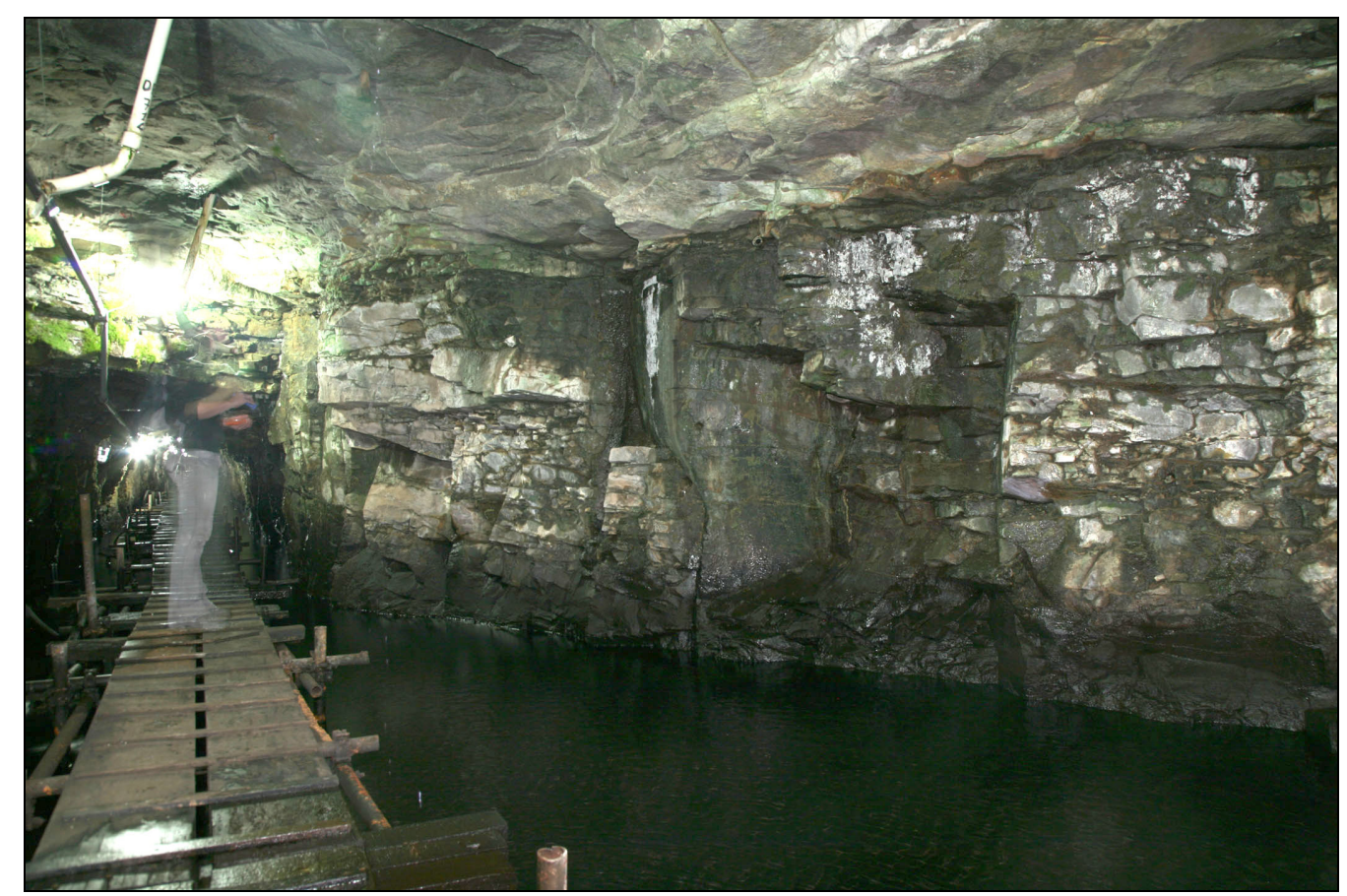

Figura 42: Horizonte fraturado, com espessura de quase 2 metros, composto por fraturas subhorizontais persistentes, de espaçamento variando entre 5 e $25 \mathrm{~cm}$ (foto de Francesco Barale). 


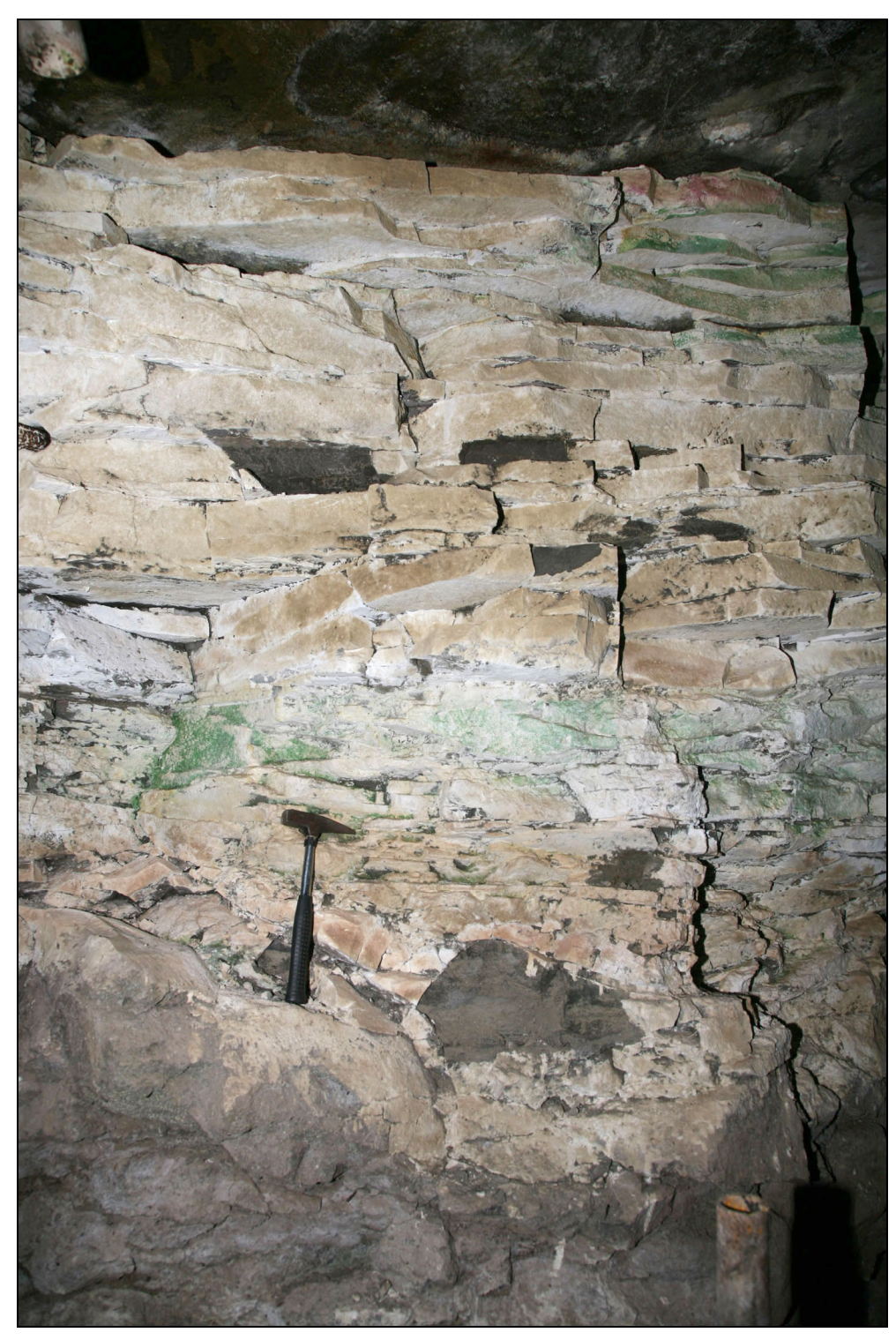

Figura 43: Horizonte fraturado com fraturas sub-horizontais medianamente contínuas, com espaçamento variando entre 3 e $20 \mathrm{~cm}$. Próximo a base do horizonte fraturado, as fraturas são curviplanares e formam lentes, já as fraturas superiores são em geral planares e definem blocos tabulares. Nota-se que abaixo do horizonte fraturado o basalto encontra-se maciço e sem fraturas.

O preenchimento da fratura sub-horizontal também varia lateralmente. Em determinados locais a fratura encontra-se aberta e sem preenchimento, possivelmente lavado pela percolação de água. Em outros, o preenchimento é centimétrico, silto-arenoso, de cor branca e verde, com cristais de quartzo e calcita. Neste caso, o material de preenchimento envolve os fragmentos de basalto, conferindo à fratura um aspecto de brecha (figura 44). $\mathrm{Na}$ 
grande maioria das vezes é observada apenas uma película milimétrica silto-arenosa no plano das fraturas, também de cor branca e verde. Este material de preenchimento é composto essencialmente por calcita, quartzo e feldspato, possivelmente decorrente da percolação de fluído hidrotermal, juntamente com alteração da rocha, devido à circulação intensa de água.

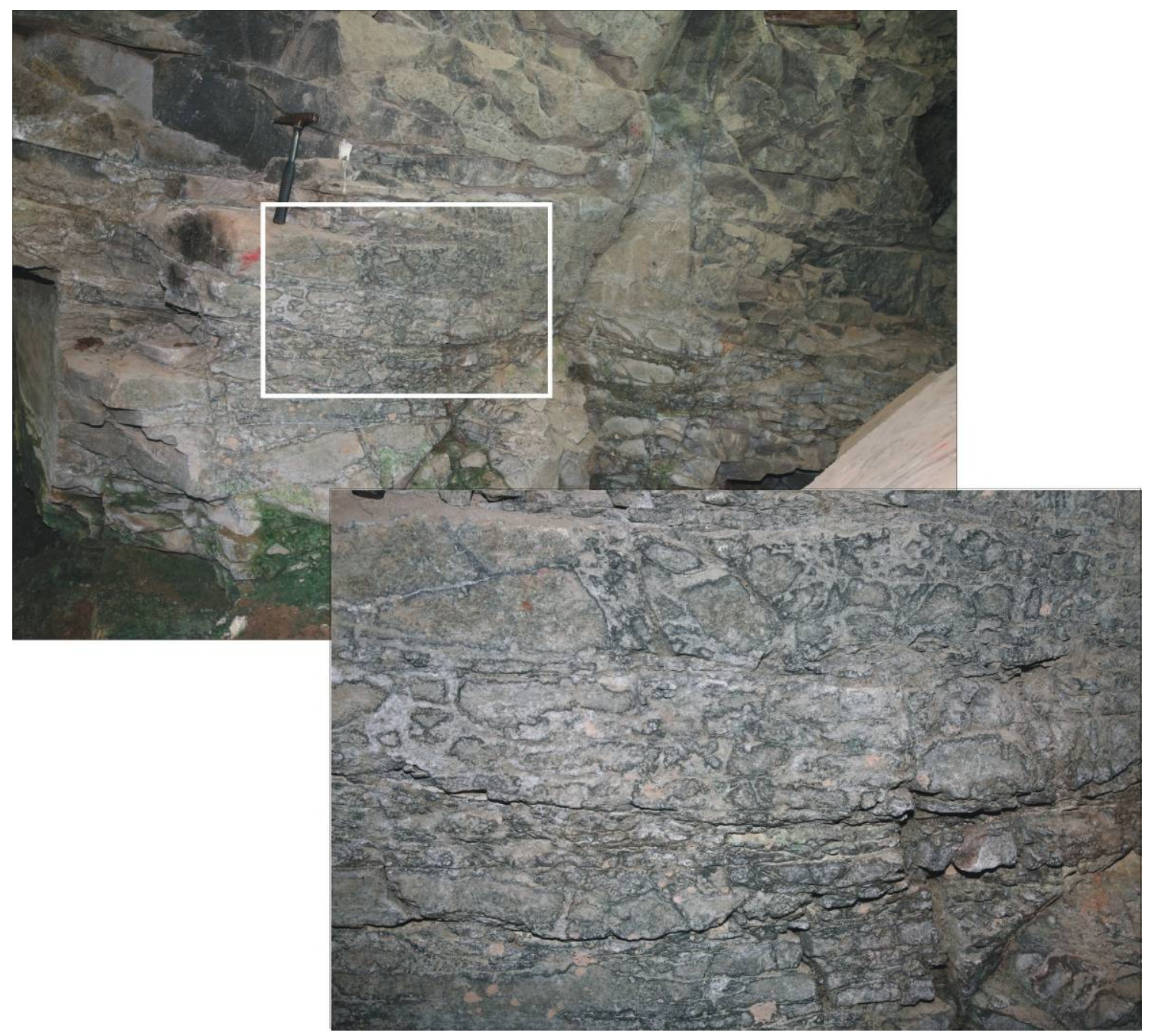

Figura 44: Horizonte fraturado, com quase 2 metros de espessura, com fraturas planares mais contínuas e curviplanares de pequena extensão. Destaque para o preenchimento das fraturas, com aspecto de brecha, definindo blocos centimétricos e orientados sub-horizontalmente, envoltos por material silto-arenoso de com branca e esverdeado, contornando os fragmentos de rocha (foto de Francesco Barale).

O horizonte fraturado ocorre em meio ao basalto maciço cinza microcristalino, composto por pequenas amígdalas dispersas, inferiores a um milímetro de diâmetro. Essas pequenas amígdalas são constituídas predominantemente por clorita e contornadas por uma 
película verde clara. Possivelmente, trata-se de um mineral secundário (esmectita), que ocorre também na matriz da rocha de forma intersticial. O túnel de prospecção da barragem expõe a base do derrame aflorante em superfície. Devido às irregularidades e ondulações do horizonte fraturado, em determinados locais esta estrutura não é observada na parede do túnel. Segundo registros bibliográficos, o basalto acima daquele interceptado pelo túnel de prospecção apresenta um sistema de disjunções colunares, com cerca de $50 \mathrm{~cm}$ de diâmetro. Acima deste, o basalto apresenta disjunções colunares de 10 a $20 \mathrm{~cm}$ de diâmetro com inclinações para rumos variáveis. Este último é coberto por um basalto vesiculo-amigdaloidal, castanho avermelhado, pouco fraturado, com lava aglomerática e basalto brechado com cimento carbonático no topo (Ussami et al. 1976). O túnel de prospecção também atravessa em profundidade a estrutura circular exposta em superfície. Nesta região ocorrem níveis de brecha basáltica, formada por blocos de basalto vesiculo-amigdaloidal de diâmetro variado, com matriz composta por cristais de calcita centimétricos (figura 45), possivelmente a fonte para o preenchimento calcítico das fraturas. O horizonte fraturado não é observado onde ocorre nesse nível de brecha.

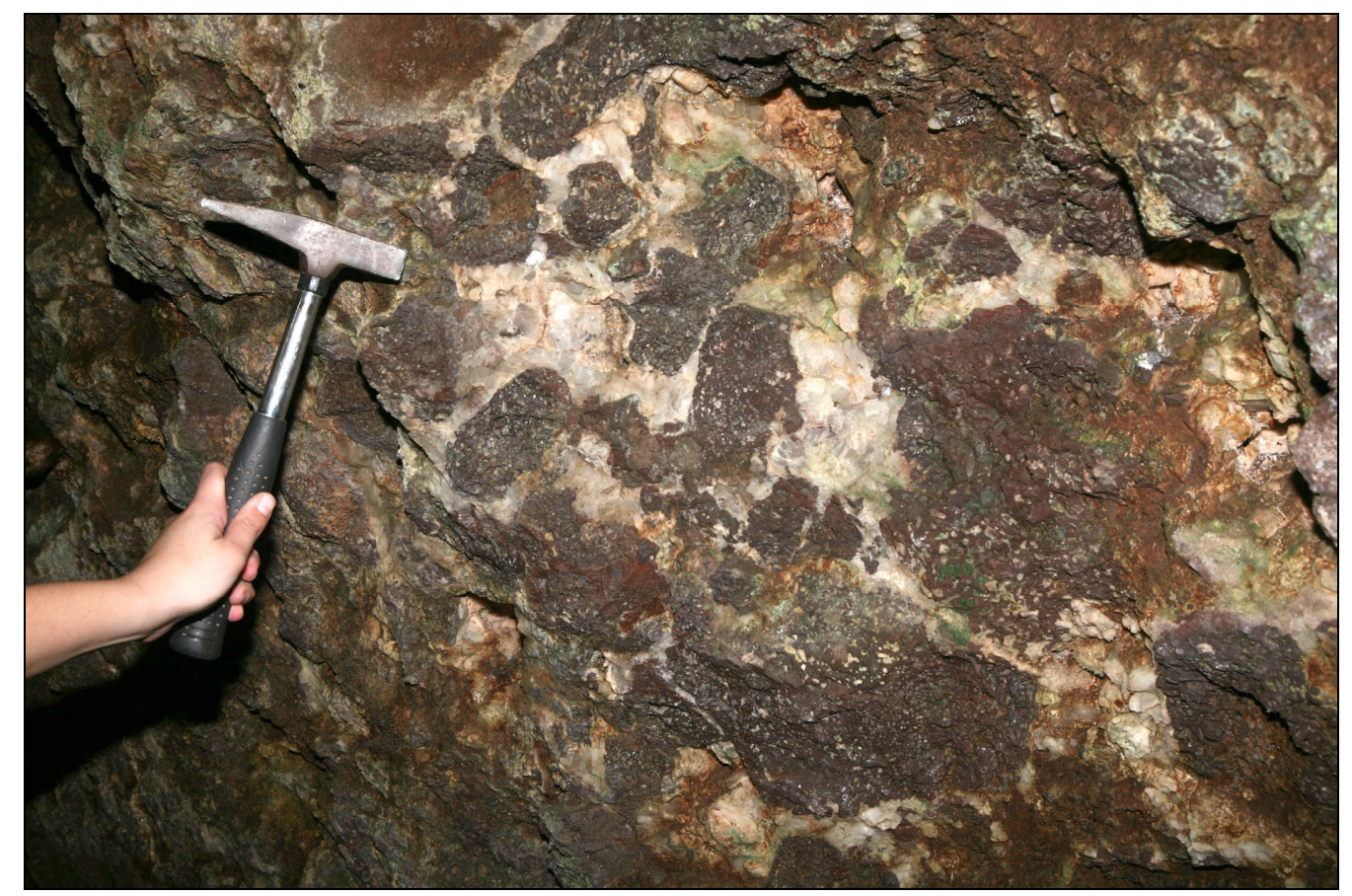

Figura 45: Brecha basáltica com blocos de basalto vesículo-amigdaloidal de diâmetro variado, com matriz formada por cristais de calcita de até $3 \mathrm{~cm}$ (foto de Francesco Barale). 
O padrão de fraturamento tabular observado no horizonte fraturado da Usina de Água Vermelha é análogo a feições de fraturas sub-horizontais consideradas como "juntas-falhas" em outras localidades. A estrutura em questão apresenta os seguintes aspectos a serem considerados: sua localização na base do derrame; comportamento sub-horizontal acompanhando o contato entre derrames; a não ocorrência dessa estrutura sobre a brecha basáltica; fraturas curviplanares de pequena continuidade lateral, formando blocos em forma tabular e como lentes; e o preenchimento das fraturas por material de percolação, característico em fluídos hidrotermais.

Essas características sugerem que esta estrutura possa estar associada ao processo de fluxo da lava, com a formação de diáclases sub-horizontais na base do derrame, correspondentes às fraturas sub-horizontais sin-magmáticas. Essa consideração baseia-se principalmente nas características do material de preenchimento da fratura, associado a fluídos hidrotermais oriundos das fases tardias de cristalização dos derrames. A percolação desse material no horizonte fraturado implica que as fraturas sejam preexistentes. Este padrão de fraturamento tabular observado no horizonte fraturado também é expressivamente similar a estrutura ligada a processos de fluxo, definida como acamamento ígneo, a qual se manifesta como um diaclasamento plano-paralelo com lajes de 10 a 20 centímetros de espessura na porção inferior de corpos extrusivos de natureza ácida (Machado 2003, Nardy et al. 2008). 


\subsection{Município de Laranjeiras do Sul (PR)}

No quilômetro 463 da rodovia BR-277, nas proximidades do Município de Laranjeiras do Sul, no Estado do Paraná, está localizado um amplo afloramento de derrames basálticos da Formação Serra Geral. Neste local, afloram dois derrames basálticos separados por uma delgada camada centimétrica a decimétrica de sedimento silto-arenoso. Os derrames possuem espessura mínima aflorante de aproximadamente 15 metros cada, sendo possível identificar a seguinte sucessão: basalto vesículo-amigdaloidal nas porções superior e inferior, com amígdalas de diâmetros centimétricos a decimétricos, formato oval e alongado, e basalto maciço no núcleo. O basalto em geral possui textura afanítica de cor cinza escuro com película avermelhada de oxidação. Os dois derrames apresentam um nível colunata, com colunas de 40 a 80 centímetros de diâmetro, sobreposto a um nível entablamento, em que as disjunções são irregulares, encurvadas e menos espaçadas, apresentando ocasionalmente colunas de 25 centímetros de espessura em média (figura 46). O derrame inferior contém um horizonte fraturado que acompanha toda a extensão do derrame, delimitando os níveis colunata e entablamento.

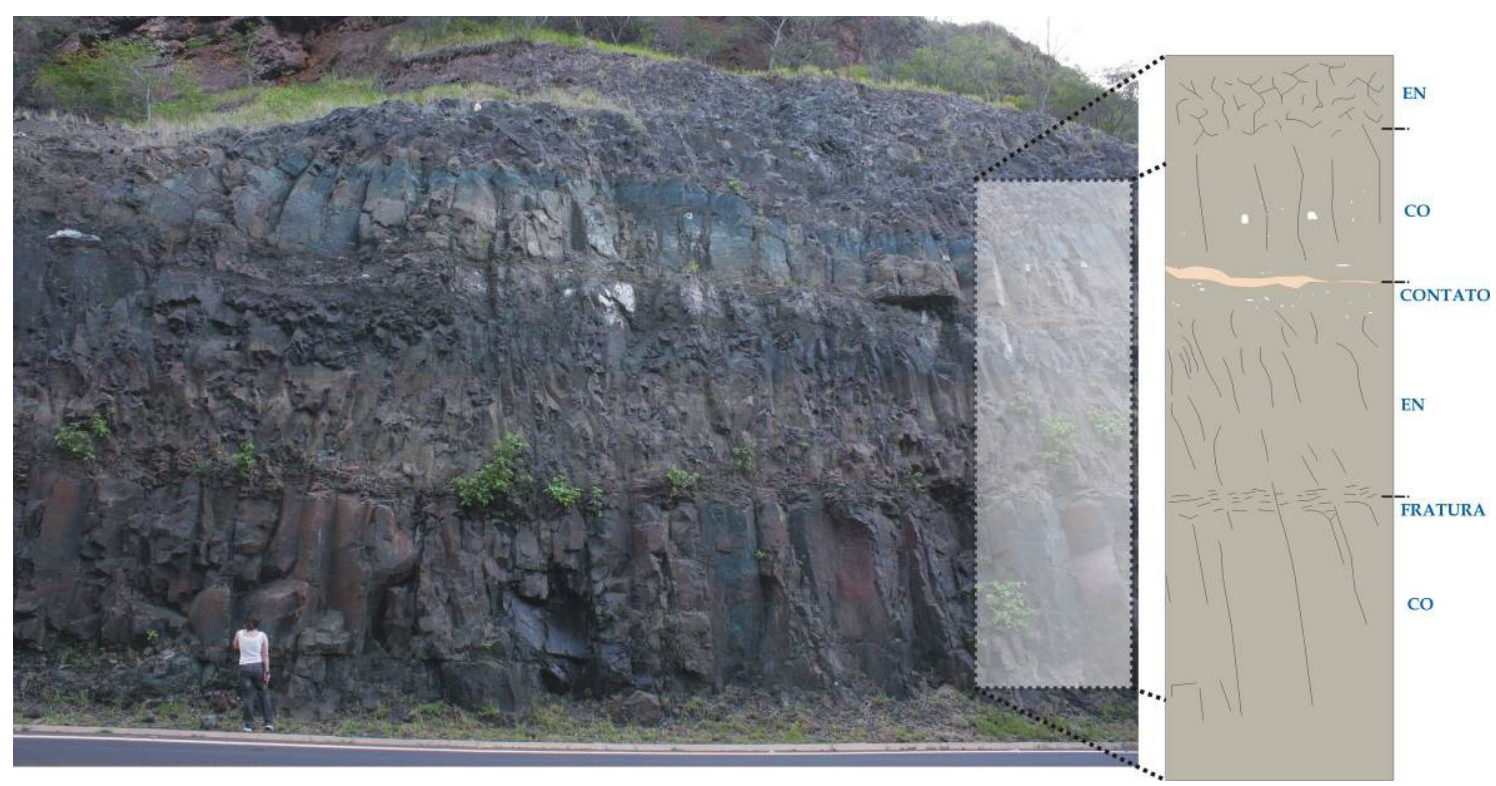

Figura 46: Ilustração indicando os níveis colunata (CO) e entablamento (EN) dos derrames superior e inferior. O contato entre os derrames é identificado por uma zona de concentração de amídalas (pontos brancos) e um nível de sedimento silto-arenoso. Entre os níveis colunata e entablamento, no derrame inferior, ocorre um horizonte fraturado bastante persistente. Quilômetro 463 da rodovia BR-277, Município de Laranjeiras do Sul (PR) (foto de Francesco Barale). 
Este horizonte fraturado possui grande continuidade lateral, acompanhando toda a extensão do derrame, por aproximadamente 200 metros. Possui comportamento predominantemente sub-horizontal, sempre perpendicular às disjunções colunares e delimitando os níveis colunata (abaixo da fratura) e entablamento (acima da fratura) (figura 47). Sua espessura é pouco variável, entre 30 e 40 centímetros.

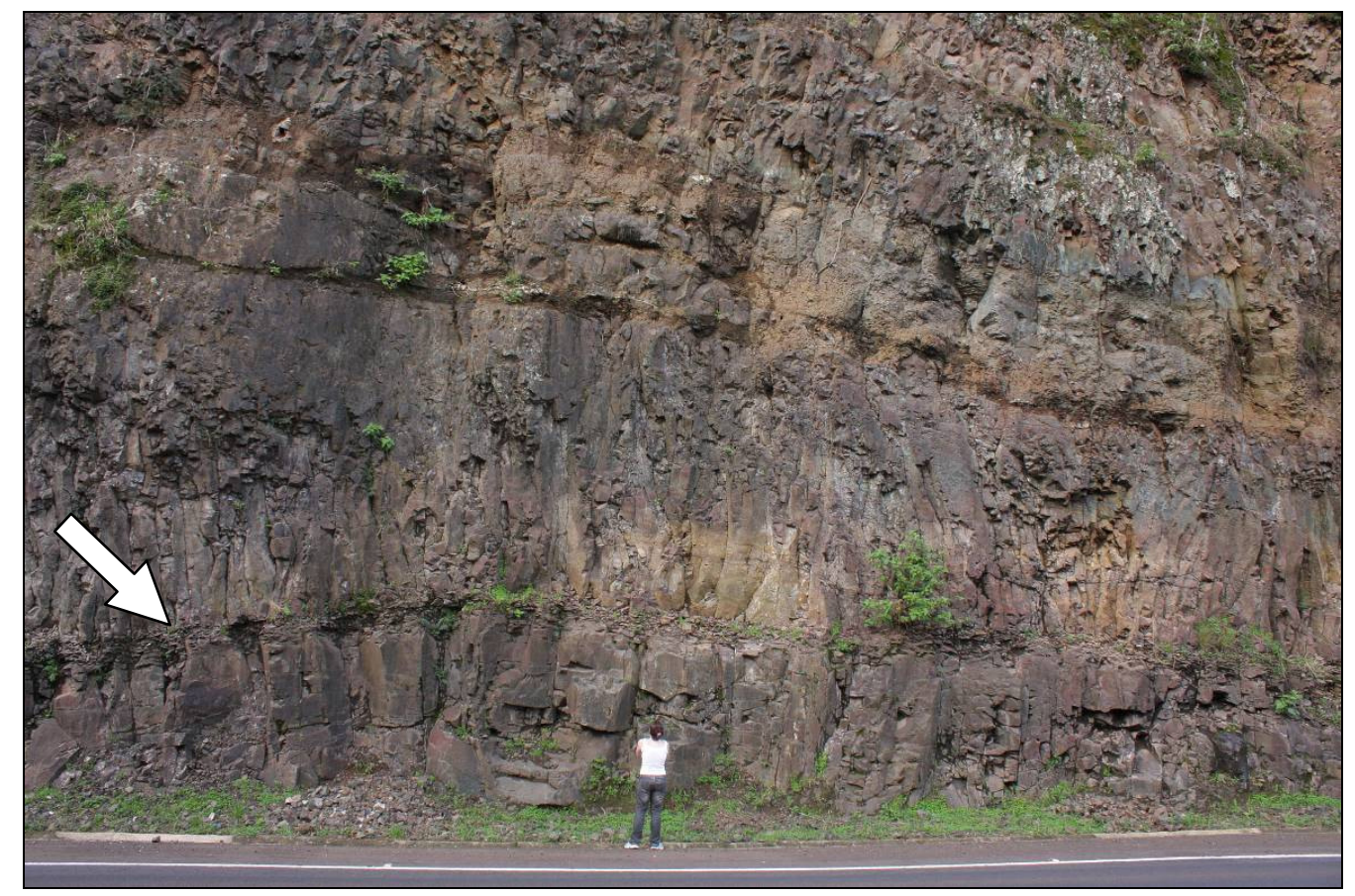

Figura 47: Horizonte fraturado indicado pela seta, separando duas porções do maciço fraturado: acima, juntas verticais irregulares e pouco espaçadas (em geral até $25 \mathrm{~cm}$ ); abaixo, juntas verticais de maior espaçamento $(40-60 \mathrm{~cm})$, formando colunas verticais mais regulares. Esses dois padrões de juntas verticais correspondem aos dois níveis estruturais, entablamento e colunata, respectivamente. As juntas verticais acompanham a ondulação do horizonte fraturado, dispostos sempre perpendiculares. Mesmo afloramento da figura anterior (foto de Francesco Barale).

O horizonte fraturado é caracterizado por juntas de pequena continuidade lateral, planares e curviplanares. As juntas sub-horizontais definem uma família de juntas subparalelas, com espaçamento de 3 centímetros em média, e são interceptadas por juntas não sistemáticas de menor persistência. Nas proximidades do horizonte fraturado são ocasionalmente observadas juntas encurvadas que se iniciam nas juntas subverticais e tendem a se horizontalizar (destaque da figura 48). O horizonte fraturado define blocos tabulares, frequentemente com película de alteração nas bordas, devido à constante percolação de água (figura 49). 


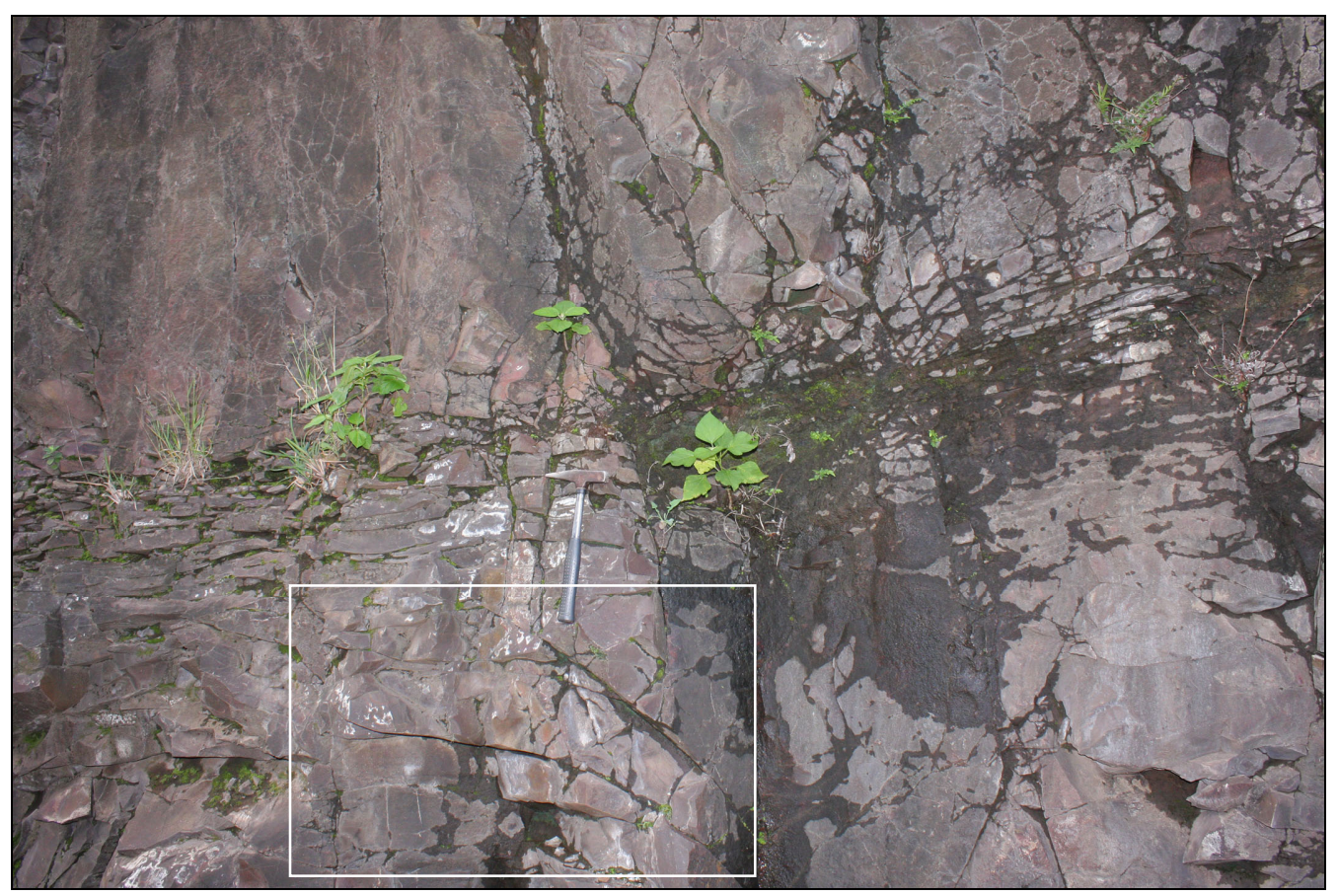

Figura 48: Detalhe do horizonte fraturado definido por uma família de juntas sub-horizontais, com espaçamento de 3 centímetros, em média, interceptadas por juntas não sistemáticas de menor persistência e orientação variada. Nesta figura a região mais escura corresponde à umidade devido à percolação de água pelas fraturas. No detalhe, algumas juntas estão encurvadas, iniciando-se na junta subvertical e se horizontalizando. Mesmo afloramento da figura anterior.
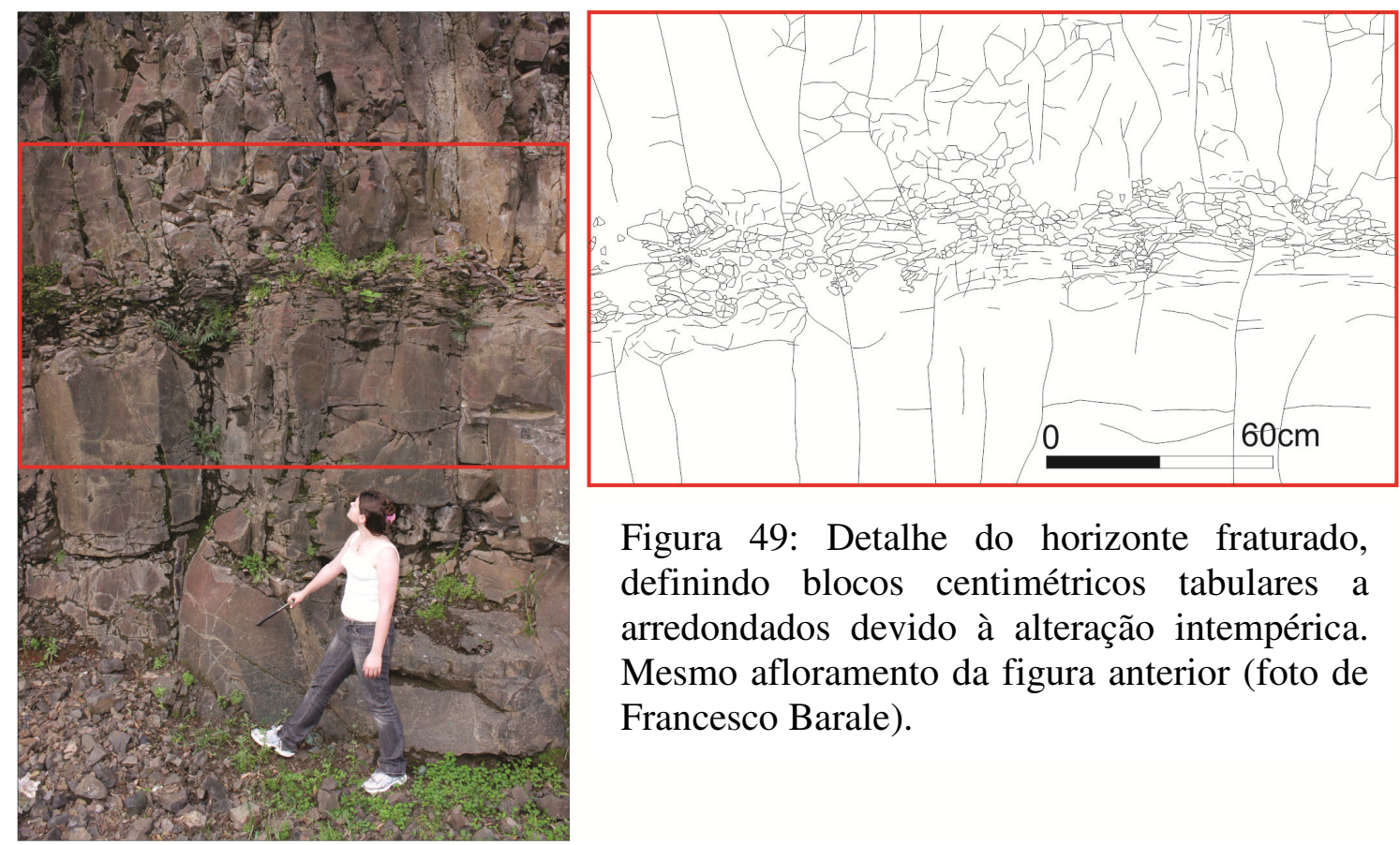

Figura 49: Detalhe do horizonte fraturado, definindo blocos centimétricos tabulares a arredondados devido à alteração intempérica. Mesmo afloramento da figura anterior (foto de Francesco Barale). 
Embora os derrames basálticos apresentem comportamento predominantemente tabular, em determinados locais eles se mostram ondulados. Neste local, o horizonte fraturado também acompanha a ondulação do derrame, apresentando ângulo de mergulho acentuado, sempre paralelo aos limites do derrame e perpendicular às disjunções colunares (figura 50).

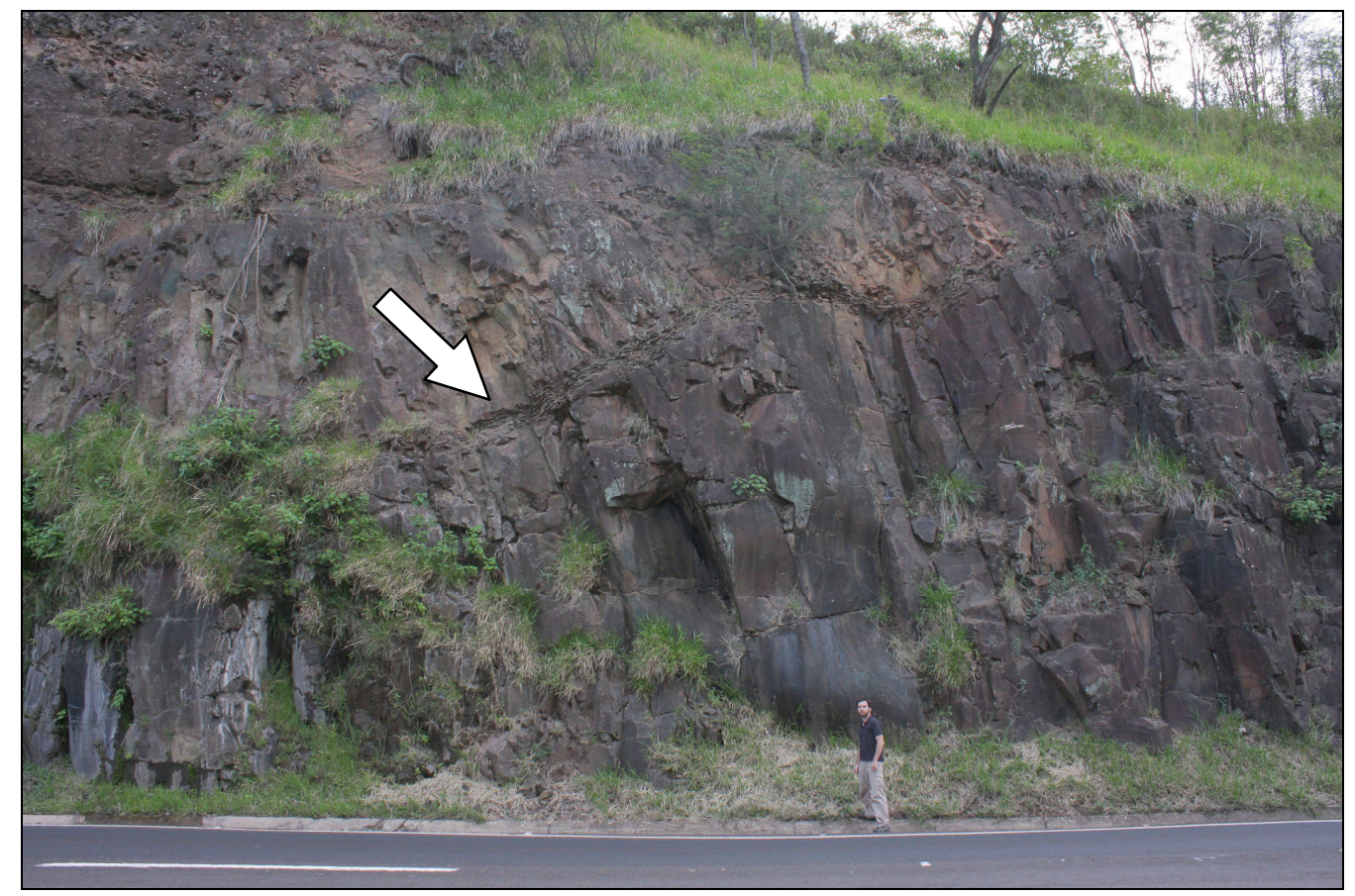

Figura 50: Derrame inferior com forte ondulação. Nota-se que o horizonte fraturado acompanha a ondulação do derrame, apresentando ângulo de mergulho acentuado, sempre paralelo aos limites do derrame e perpendicular as disjunções colunares acima e abaixo dele. Mesmo afloramento da figura anterior.

Este horizonte fraturado está diretamente associado às feições primárias do derrame. Seu comportamento sub-paralelo aos limites do derrame e perpendicular às disjunções colunares, nitidamente delimitando os níveis colunata e entablamento, sugerem que sua formação esteja condicionada pelo evento de resfriamento do derrame basáltico. Outro indício que corrobora com essa hipótese, diz respeito ao encurvamento que algumas juntas apresentam. Na figura 51 é possível identificar que o horizonte fraturado se dissipa quando atinge uma forte inclinação, restando apenas uma junta que se inicia no horizonte fraturado e se encurva ascendentemente. Nota-se que mesmo no final do horizonte fraturado as disjunções colunares continuam perpendiculares a ele. 


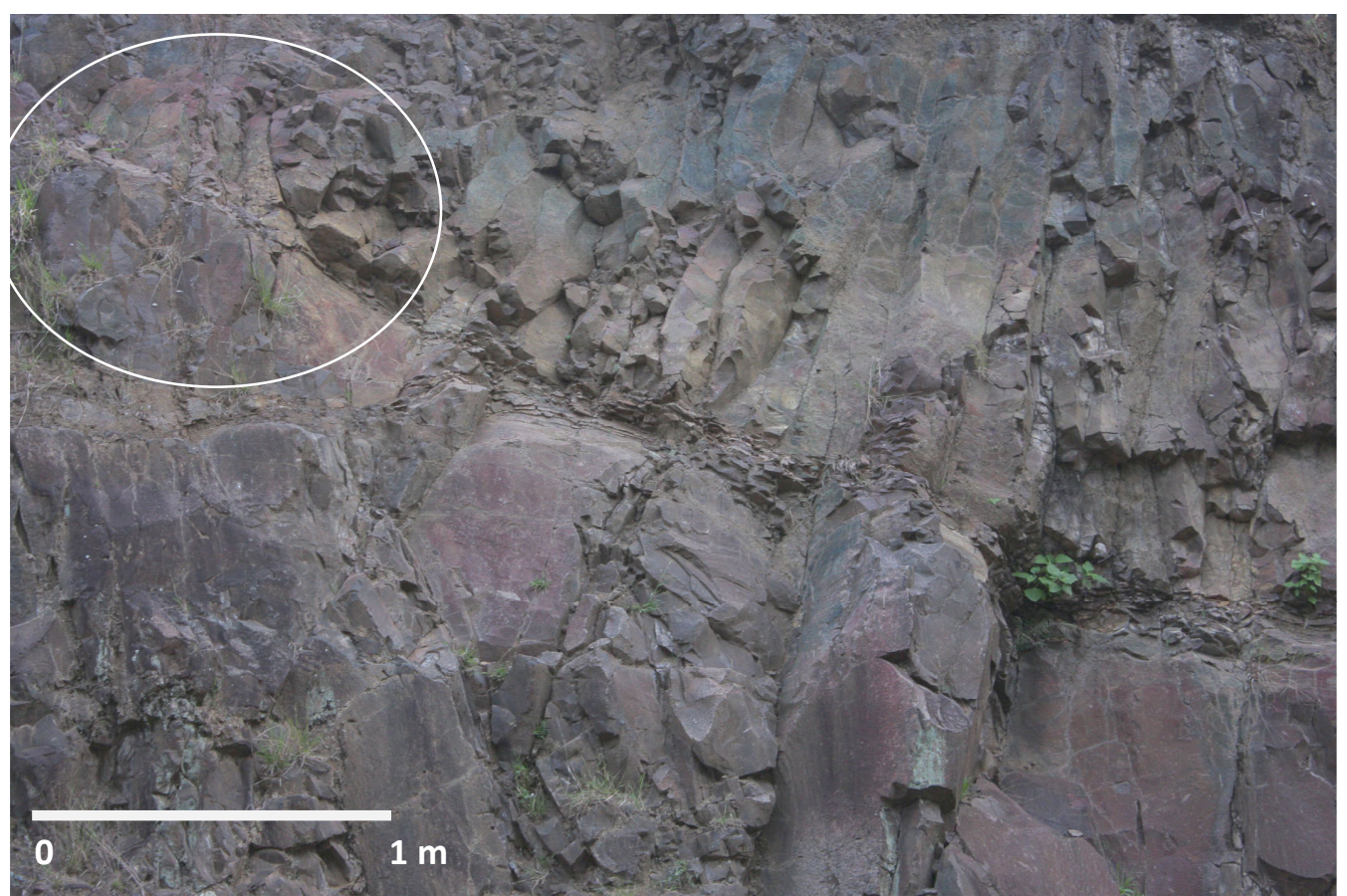

Figura 51: Horizonte fraturado inclinado. No círculo branco, nota-se o encurvamento para cima de diáclases a partir do horizonte fraturado e a diferença das diáclases acima e abaixo da faixa fraturada, com colunas mais delgadas e irregulares acima do que abaixo. Mesmo afloramento da figura anterior.

O processo de resfriamento que se inicia das periferias para o centro do derrame gera os níveis colunata, pela frente de resfriamento ascendente, e entablamento, pela frente de resfriamento descendente. $\mathrm{O}$ encontro das duas frentes de resfriamento promove uma descontinuidade em meio ao basalto maciço. Embora esse processo não explique como as fraturas sub-horizontais são formadas, o encurvamento de algumas juntas observadas em campo sugere que, de alguma forma, as juntas tendem a se horizontalizar quando se aproximam do encontro dos dois níveis estruturais. Esse processo corresponde à geração de fraturas sub-horizontais tardi-magmáticas. 


\subsection{Município de Ribeirão Preto (SP)}

A pedreira visitada no Município de Ribeirão Preto está localizada no quilômetro quatro da rodovia que liga Ribeirão Preto a Araraquara (SP-255). Neste local, afloram derrames basálticos eocretáceos da Formação Serra Geral, morfologicamente tabulares e com espessuras de 45 a 100 metros (Fernandes et al. 2010a). O derrame aflorante na área da pedreira corresponde a um basalto afanítico, cor cinza escuro, com espessura de pelo menos 70 metros. Grande parte de sua exposição compreende a zona de basalto maciço do núcleo do derrame, caracterizado pela presença de disjunções pseudo-colunares encurvadas. Ainda que as disjunções colunares não sejam bem desenvolvidas, é possível identificar uma diferença quanto ao espaçamento e regularidade das juntas sub-verticais, que definem na zona de núcleo do derrame dois níveis estruturais distintos (colunata abaixo e entablamento acima) (Figura $52)$.

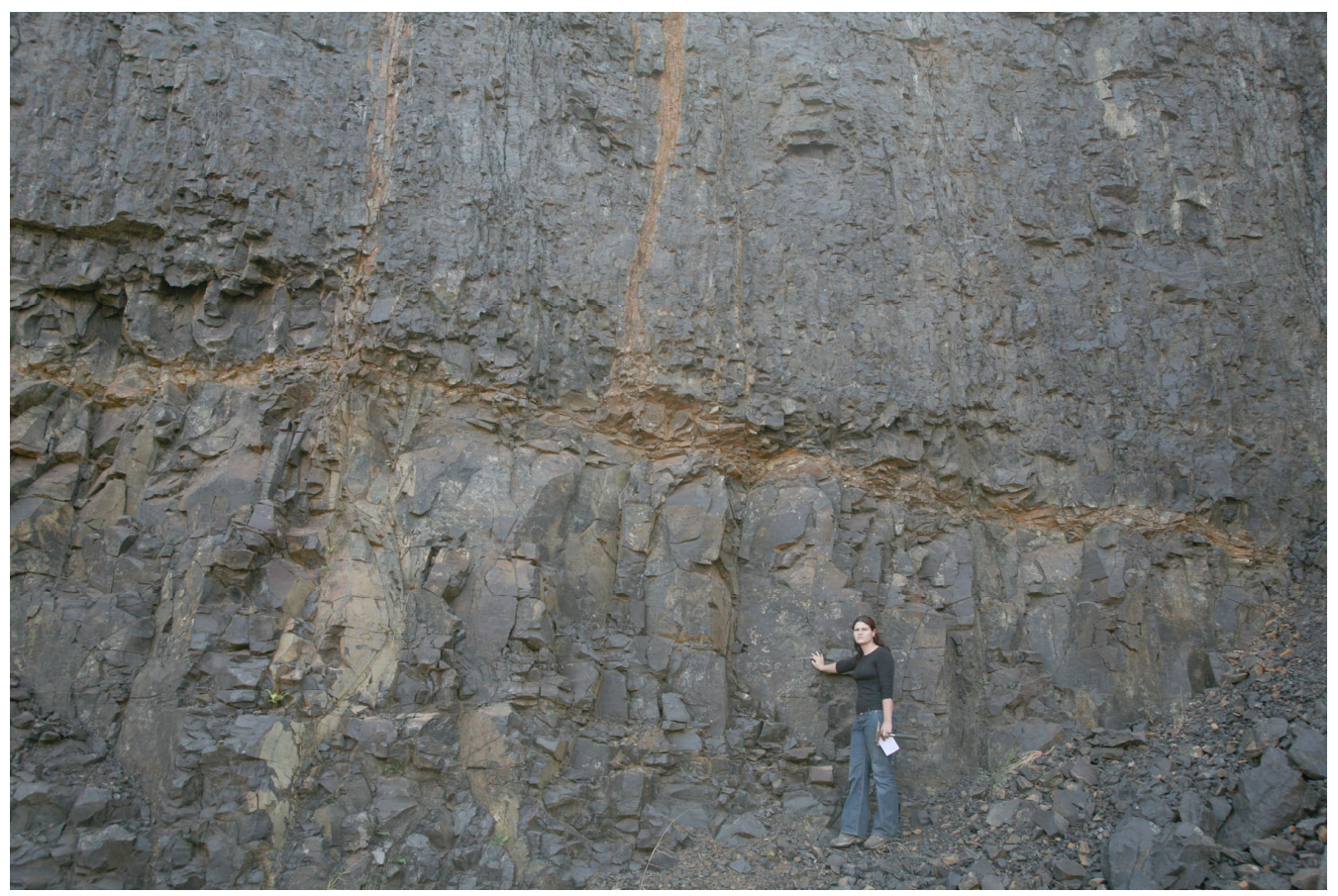

Figura 52: Zona de basalto maciço do núcleo do derrame, com dois níveis estruturais distintos, separados por um horizonte fraturado e intemperizado. $\mathrm{O}$ nível superior possui disjunções sub-verticais curviplanares, com espaçamento de 5 a $15 \mathrm{~cm}$ (entablamento), e o nível inferior possui disjunções sub-verticais curviplanares com espaçamento que varia de 15 a $60 \mathrm{~cm}$ (colunata). Pedreira no quilômetro 4 da rodovia SP-255 no Município de Ribeirão Preto (SP) (foto de Francesco Barale). 
O nível superior é caracterizado por disjunções sub-verticais curviplanares, com espaçamento de 5 a 15 centímetros em geral, e pode corresponder ao nível entablamento. $\mathrm{O}$ nível inferior possui disjunções sub-verticais curviplanares com espaçamento que varia em geral de 15 a 60 centímetros, possivelmente correspondente ao nível colunata. Os dois níveis são delimitados por uma descontinuidade sub-horizontal que acompanha toda a extensão do derrame aflorante.

Esta descontinuidade corresponde a um horizonte fraturado com 20 centímetros de espessura em média (figura 53). Este horizonte é definido por fraturas planares e curviplanares não sistemáticas e pouco persistentes e fraturas que apresentam maior continuidade lateral, preferencialmente sub-horizontais. Como pode ser observado na figura 53, no interior do horizonte fraturado ocorre uma fratura sub-horizontal de grande continuidade lateral (de ordem decimétrica a métrica), com algumas irregularidades. Essa fratura possui abertura de poucos centímetros, preenchida principalmente por zeólitas, calcita, quartzo e material de alteração do basalto. Adjacente a ela, ocorrem fraturas de pequena persistência lateral, planares e curviplanares, não sistemáticas, definindo blocos de basalto tabulares e em forma de cunha, de dimensões centimétricas à decimétricas e com presença de películas de alteração e oxidação.

Em campo foram coletados dados de atitude da fratura sub-horizontal de grande continuidade lateral e plotados em estereogramas (diagrama de Schmidt-Lambert, hemisfério inferior), empregando-se o programa computacional Stereo32, versão 1.0.2 (figura 54). O horizonte fraturado encontra-se pouco ondulado, com concentração de pólos de planos de fraturas de maior continuidade no centro do estereograma. As fraturas apresentam atitudes bastante dispersas, porém com direção preferencial NE-SW e mergulhos que variam de $15^{\circ}$ a $45^{\circ}$, preferencialmente para SE. 


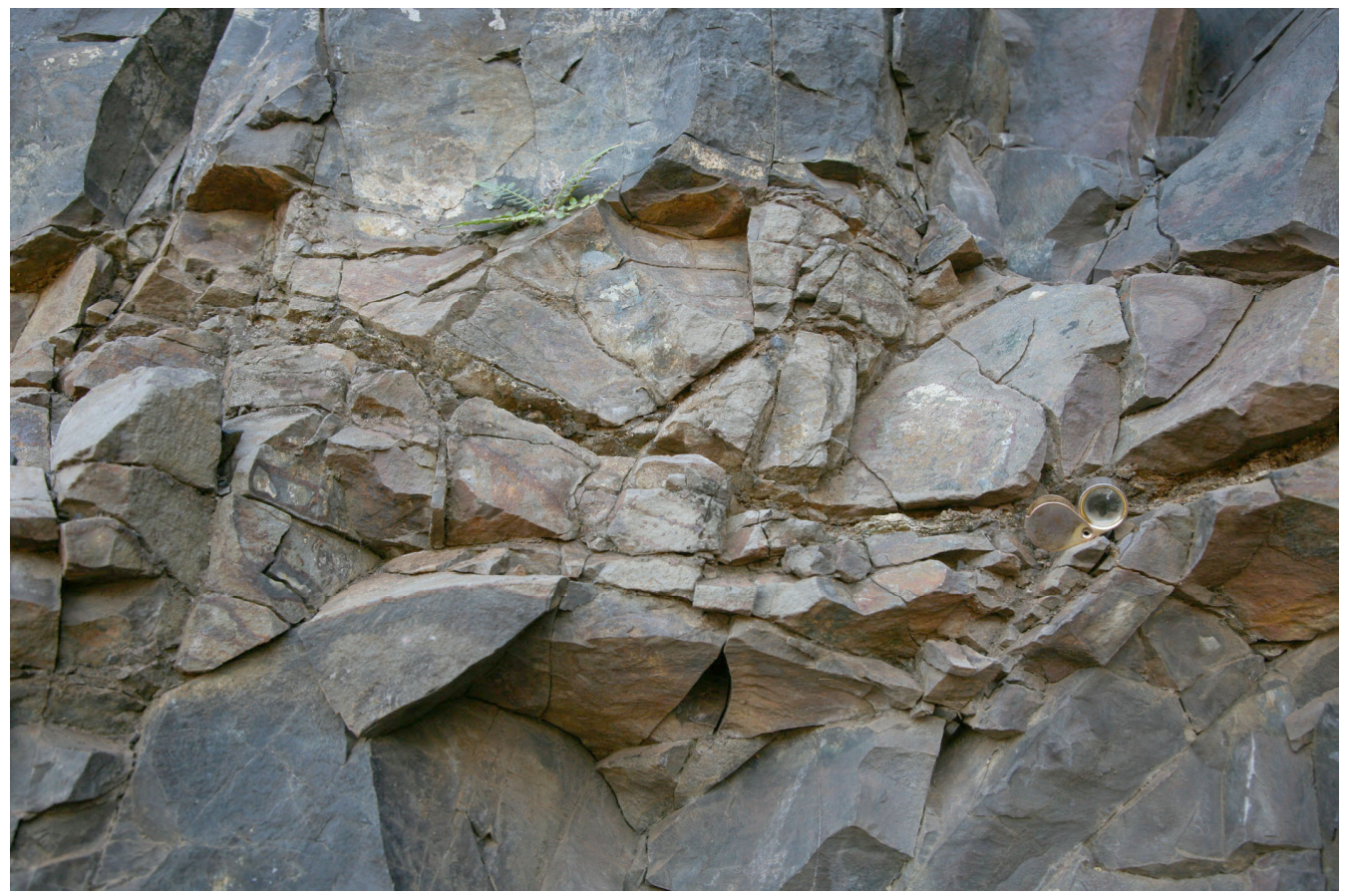

Figura 53: Detalhe do horizonte fraturado que delimita os níveis colunata e entablamento. Este horizonte encontra-se medianamente alterado, evidenciado pela descoloração do basalto. No seu interior ocorre uma fratura sub-horizontal de ordem decimétrica a métrica, com abertura de 2 a $3 \mathrm{~cm}$, preenchida por zeólitas, calcita e quartzo e material de alteração do basalto. As fraturas adjacentes possuem pequena continuidade lateral, dispostas aleatoriamente, planares e curviplanares. $\mathrm{O}$ horizonte fraturado define blocos em forma de cunha e tabulares de dimensões centimétricas à decimétricas, com películas de alteração e oxidação.
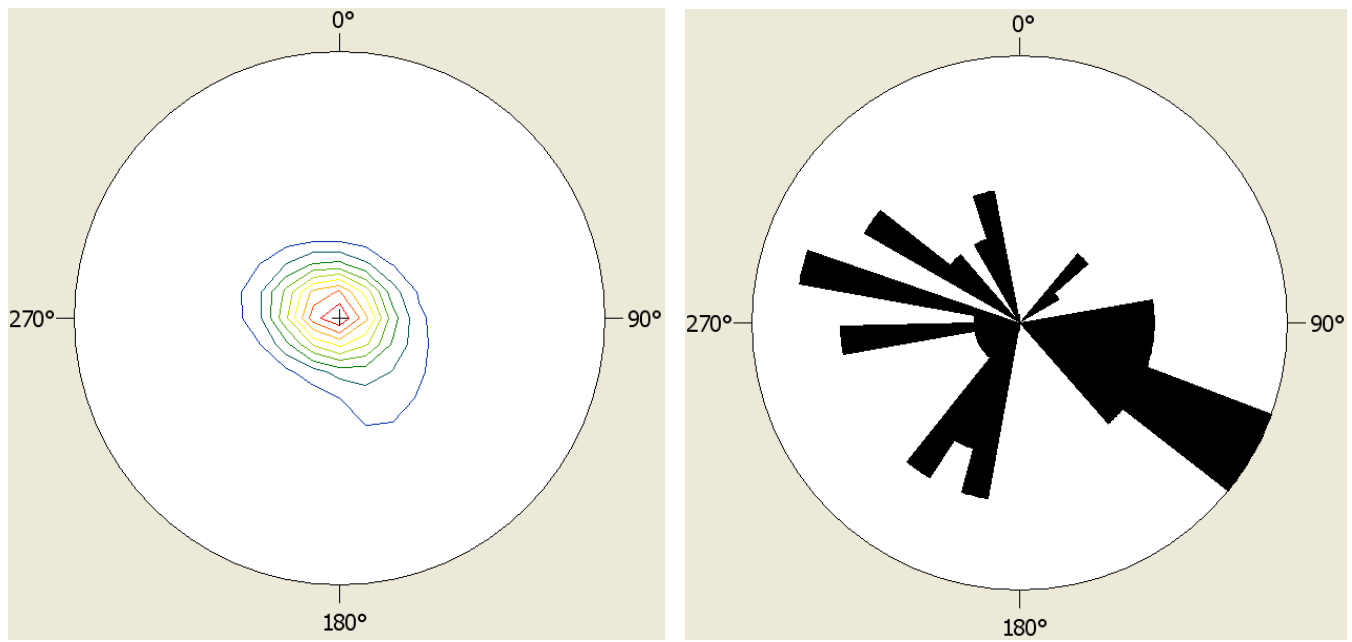

Figura 54: Estereograma representando a distribuição polar dos planos das fraturas de maior continuidade que definem o horizonte fraturado (esquerda). Rosácea com a representação do sentido de mergulho das fraturas, que se apresentam bastante dispersas, porém, com um sentido preferencial de mergulho para SE (direita) (hemisfério inferior). 
No local da pedreira também ocorrem algumas fraturas sub-horizontais que interceptam o nível de entablamento. Essas fraturas possuem continuidade lateral moderada, com cerca de 3 a 6 metros de extensão. Elas cruzam as disjunções subverticais de resfriamento, sem que se note qualquer diferenciação quanto ao estilo de fraturamento acima e abaixo da fratura sub-horizontal (figura 55). As fraturas sub-horizontais ocorrem como duas ou três fraturas paralelas com espaçamento de 1 a 3 centímetros e continuidade lateral de até uma ou duas dezenas de metros. Encontram-se normalmente preenchidas por uma película milimétrica composta por zeólitas, calcita, quartzo e material de alteração do basalto.

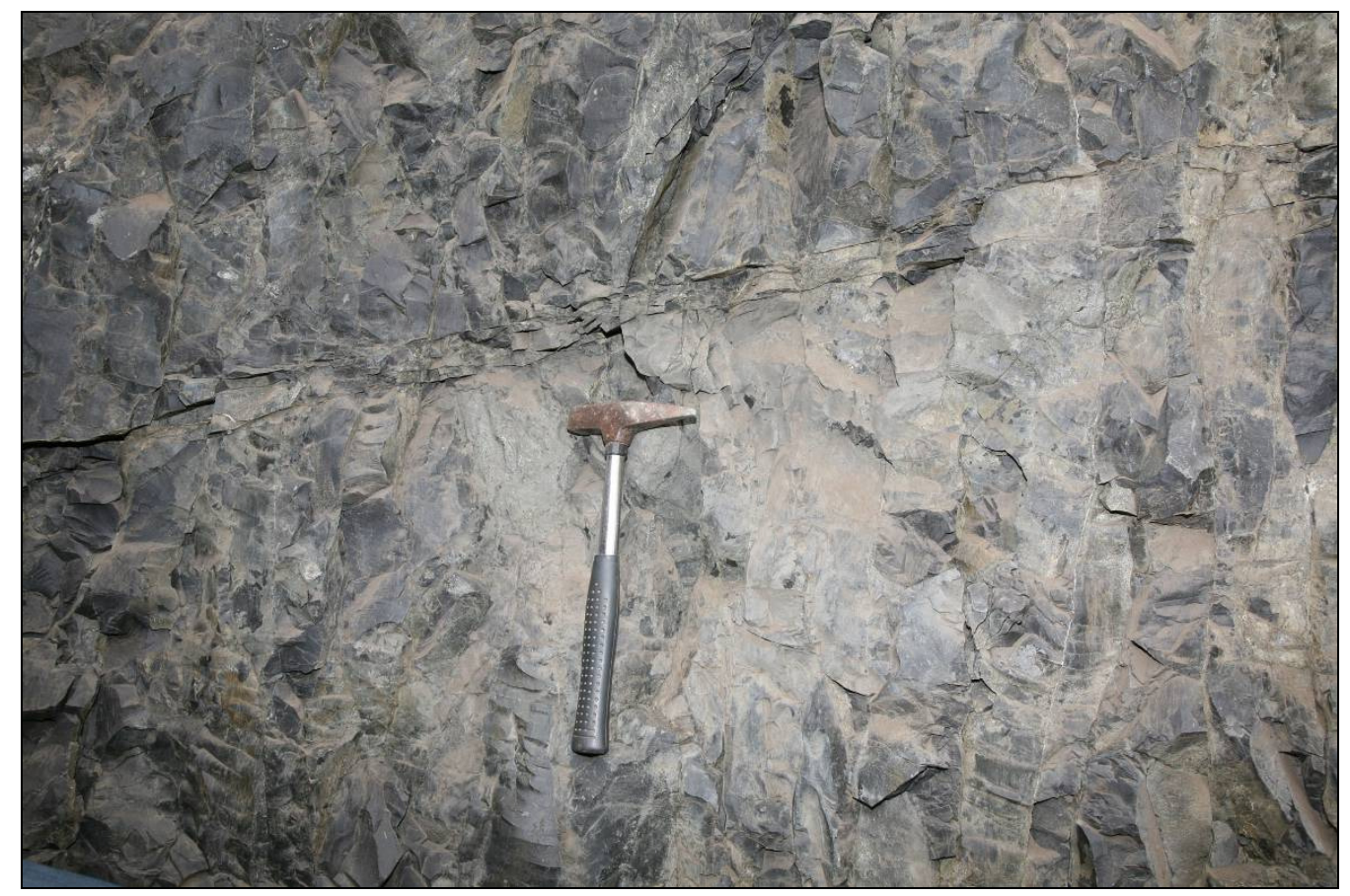

Figura 55: Fratura sub-horizontal com continuidade lateral de 6 metros de extensão, pouco ondulada, com película milimétrica preenchendo o plano da fratura, composta por zeólitas, calcita, quartzo e material de alteração do basalto. Esta fratura ocorre no nível de entablamento do derrame basáltico, em meio às disjunções subverticais de resfriamento.

Em meio ao basalto maciço do núcleo do derrame ocorre uma zona de brecha com formato tabular ondulado, de comportamento em geral sub-horizontal, com espessura de até 1,5 metro, que se encontra entre os níveis colunata e entablamento (figura 56). Esta zona de brecha é composta por fragmentos angulosos de basalto pouco alterado, com matriz de cor branca e verde, composta essencialmente de calcita, zeólitas e quartzo (figura 57). No interior 
e nas proximidades da zona de brecha ocorrem fraturas sub-horizontais de pequena continuidade lateral, sub-paralelas, com espaçamento de poucos centímetros.

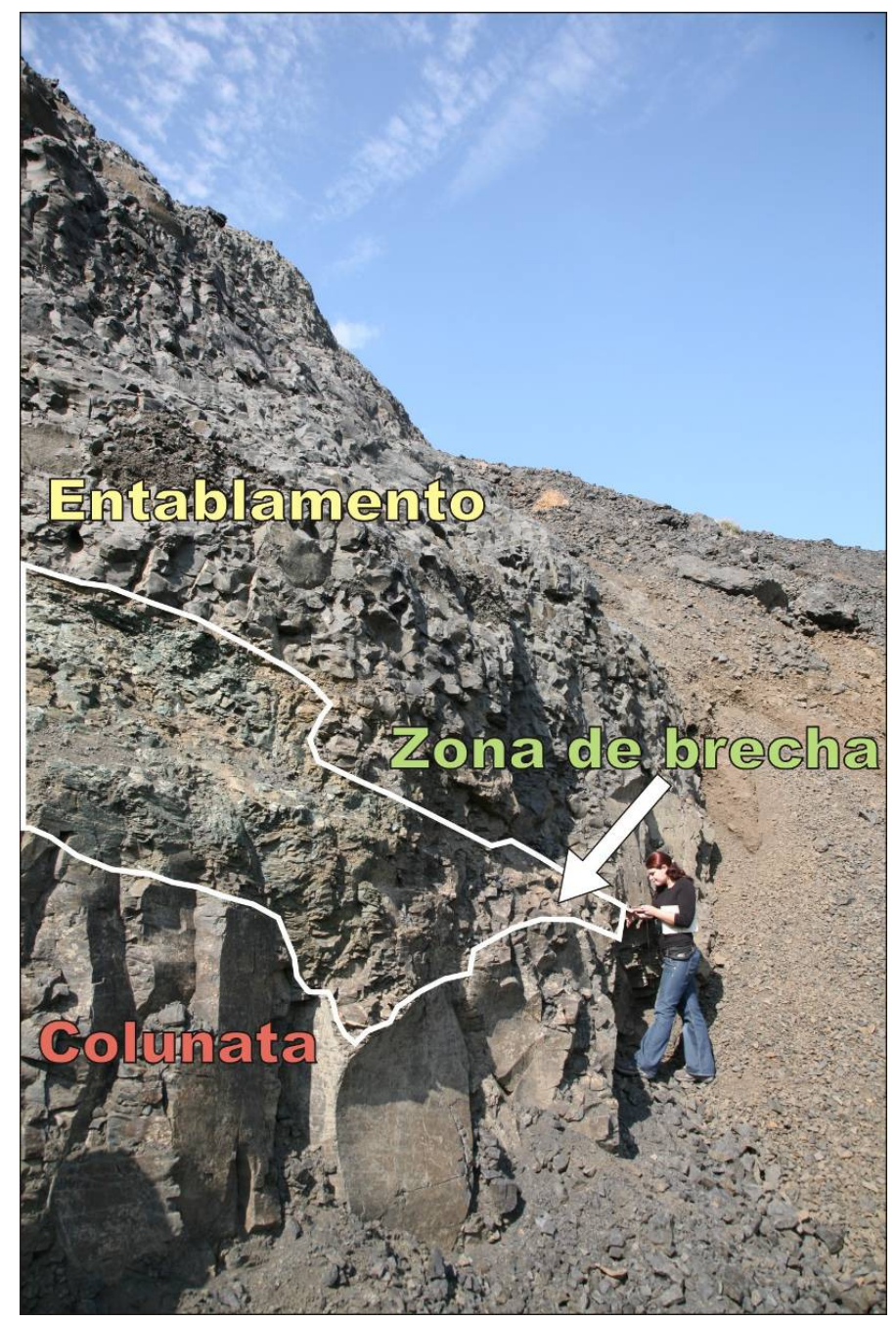

Figura 56: Zona de brecha composta por fragmentos angulosos de basalto pouco alterado, com matriz de cor branca e verde, localizada entre os níveis colunata e entablamento do núcleo do derrame. Possui formato tabular ondulado, comportamento sub-horizontal e espessura de até 1,5 metro. 


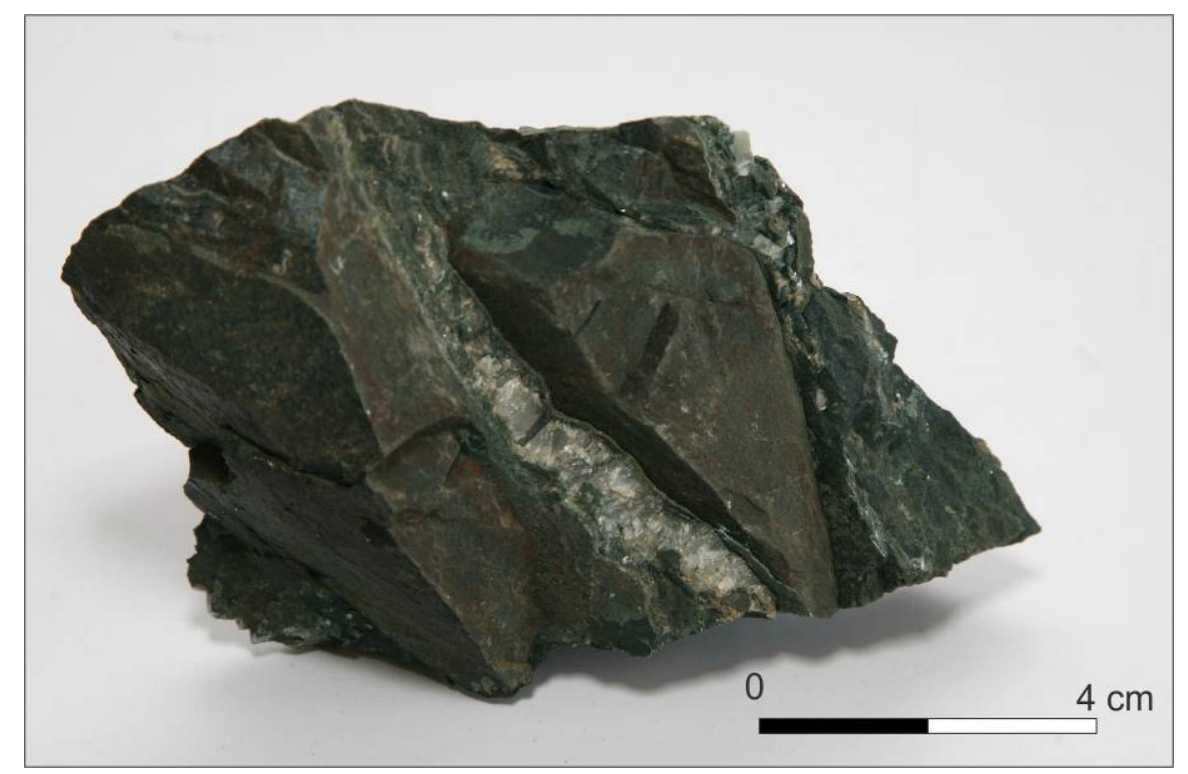

Figura 57: Amostra extraída do interior da zona de brecha composta por fragmentos de basalto angulosos rodeados por calcita fibrosa e película verde.

Esta zona de brecha está associada lateralmente a um horizonte fraturado de grande continuidade lateral, com cerca de centenas de metros de extensão (figura 58). O horizonte é definido por fraturas sub-horizontais com extensão de até 10 metros, dispostas paralelamente e ocasionalmente truncadas (figura 59). As fraturas sub-horizontais normalmente se encontram preenchidas, variando desde uma película milimétrica (figura 60) até uma camada de espessura centimétrica composta por material de alteração, quartzo, zeólitas, calcita e fragmentos de basalto de tamanhos variados (figura 61). Em determinados locais as fraturas sub-horizontais se resumem a uma família de fraturas paralelas, pouco espaçadas que se encontram fechadas pelo preenchimento de espessura milimétrica (figura 62). Embora em alguns pontos este horizonte pareça representar uma descontinuidade entre os níveis colunata e entablamento, em toda sua extensão muitas fraturas sub-horizontais interceptam disjunções subverticais, sem que se note qualquer diferença entre a espessura das colunas abaixo e acima da fratura. Nas figuras 61 e 62 é possível notar que as disjunções subverticais acima e abaixo da fratura sub-horizontal possuem espessura e comportamento curviplanar semelhantes, compatíveis com as características do nível de entablamento. 


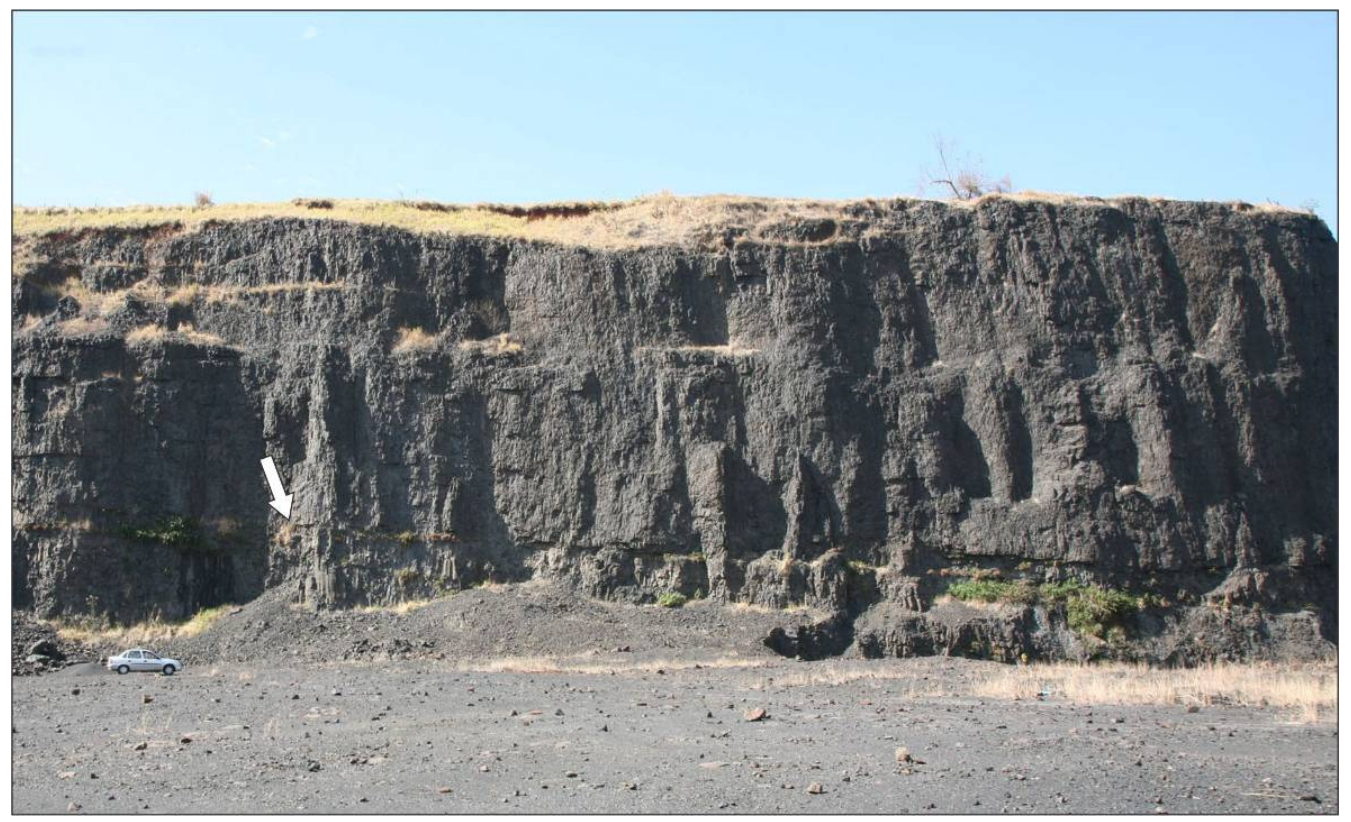

Figura 58: Horizonte fraturado de grande continuidade lateral, com comportamento subhorizontal e pouco ondulado, indicado pela seta branca.

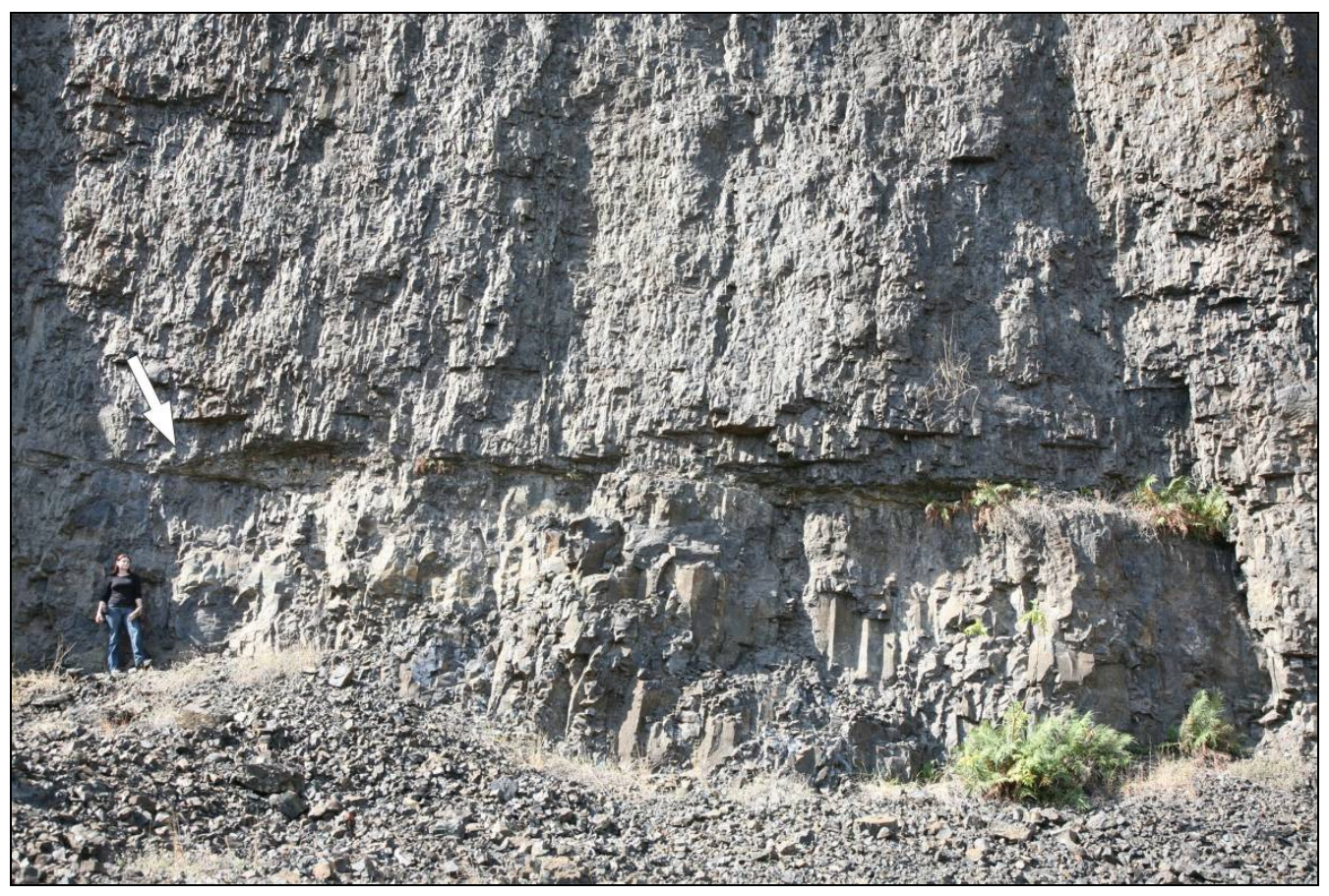

Figura 59: Horizonte fraturado definido por fraturas sub-horizontais de até $10 \mathrm{~m}$ de extensão. Essas fraturas ocorrem paralelamente umas às outras, podendo ocasionalmente se truncar, como indicado pela seta. 


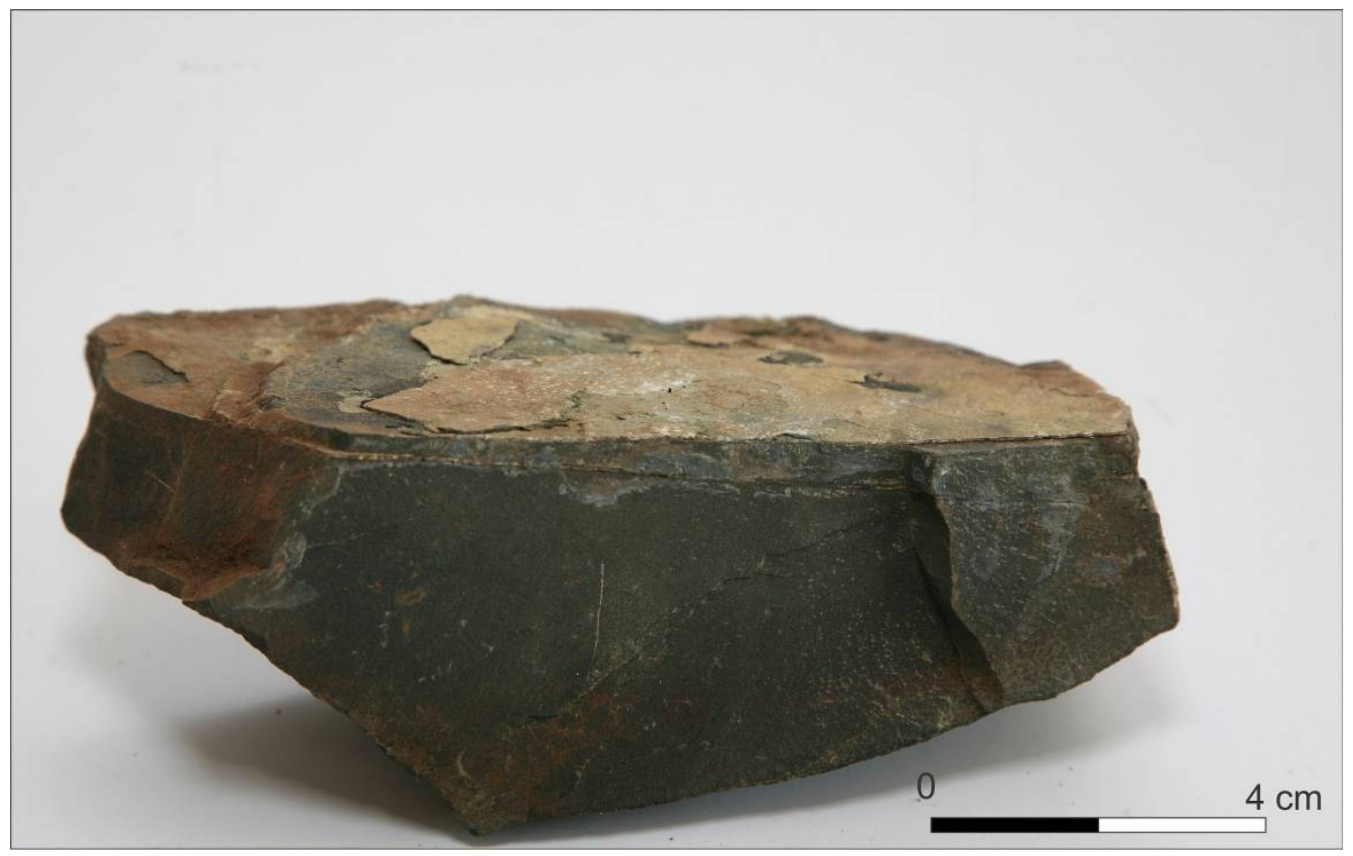

Figura 60: Amostra com película milimétrica de quartzo e calcita pouco oxidada, como material de preenchimento das fraturas.

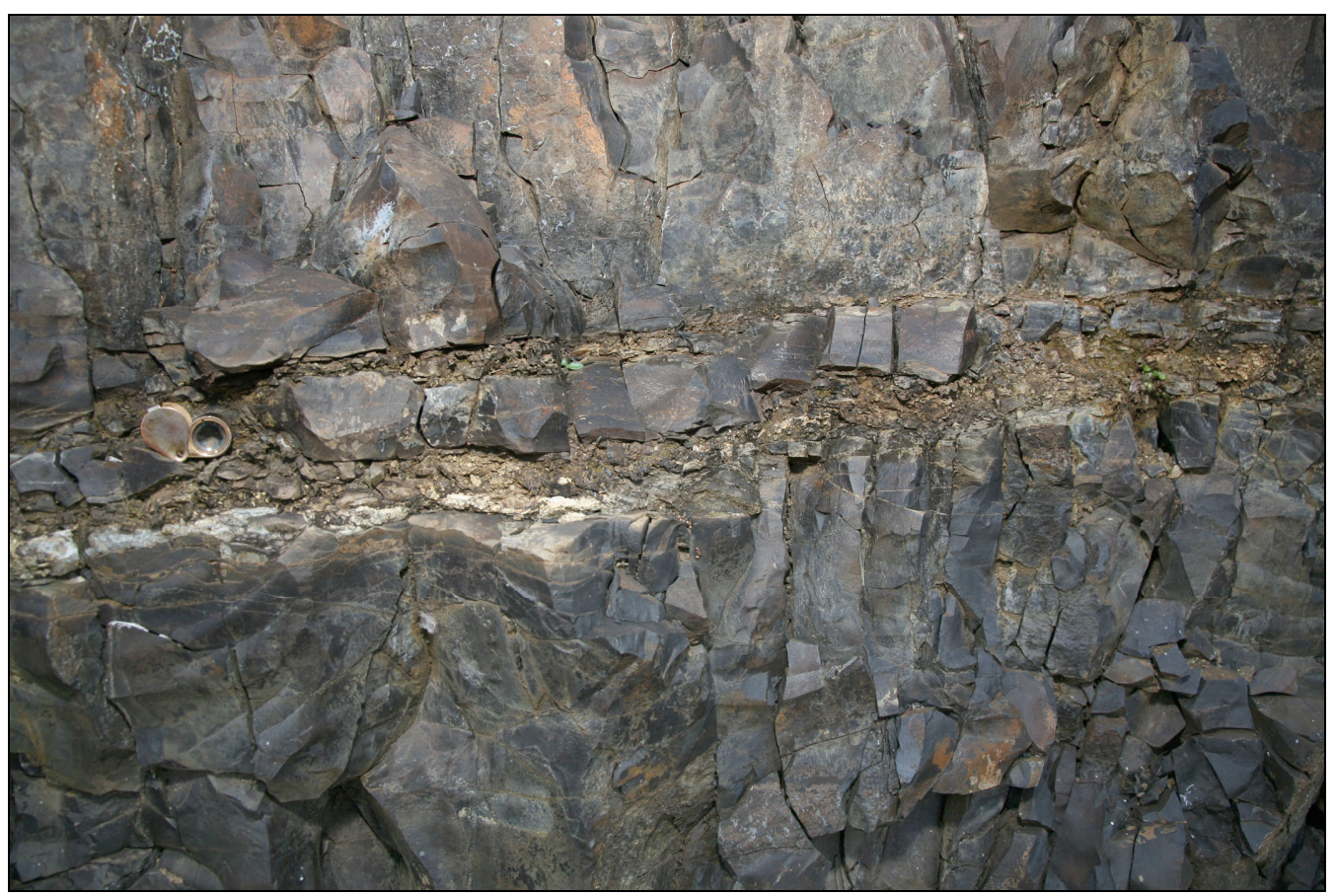

Figura 61: Fratura sub-horizontal com preenchimento de espessura centimétrica, composto por material de alteração, quartzo, zeólitas, calcita e fragmentos de basalto de tamanhos variados. 


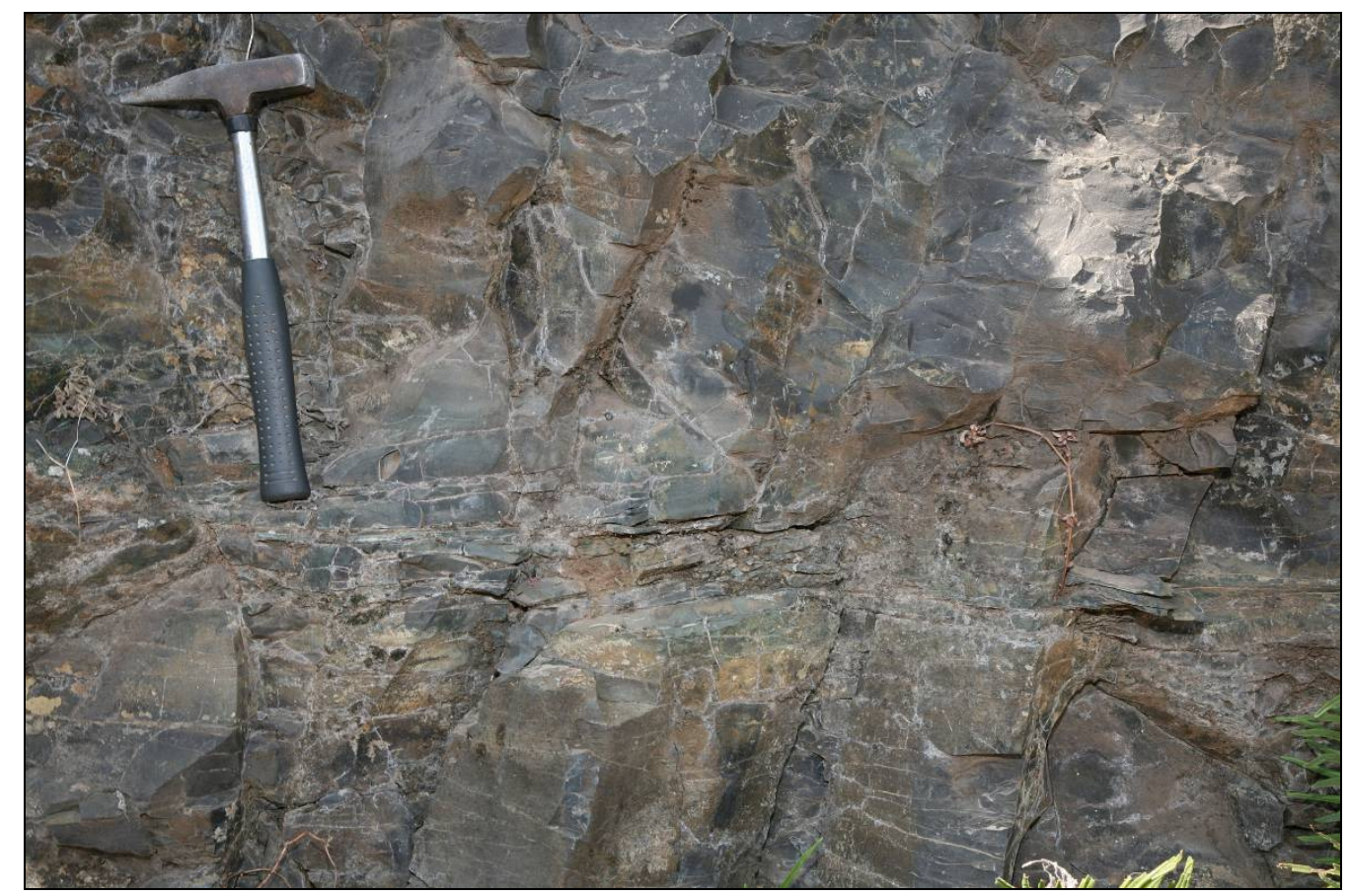

Figura 62: Horizonte fraturado definido por uma família de fraturas paralelas, pouco espaçadas, que se encontram fechadas pelo preenchimento de espessura milimétrica.

As fraturas sub-horizontais encontradas nesta pedreira, associadas ao processo de resfriamento do derrame, ocorrem entre os níveis colunata e entablamento. A zona de brecha encontrada neste local pode ter sido gerada pelo acúmulo de fluídos hidrotermais em zonas fraturadas preexistentes, mobilizados hidraulicamente pela alta pressão de fluídos. Em determinados locais as fraturas sub-horizontais apresentam ramificações, como truncamentos. Fernandes et al. (2010b) consideraram tais feições como estruturas de cisalhamento geradas por esforços compressivos horizontais, aproveitando o horizonte de contato entre os níveis colunata e entablamento. O truncamento das fraturas sub-horizontais ocorre na região onde não é possível identificar claramente o contato entre os níveis colunata e entablamento, sendo que as fraturas sub-horizontais interceptam as disjunções colunares de resfriamento sem a ocorrência de deslocamentos das juntas verticais, acima e abaixo da fratura horizontal. Dessa forma, fraturas sub-horizontais truncadas podem estar associadas ao avanço irregular das frentes de resfriamento ascendentes e descendentes.

Os horizontes fraturados são rotas preferenciais de percolação de água, o que intensifica o processo de alteração ao longo dessas descontinuidades. Em locais onde a percolação de água é intensa os fragmentos de basalto no interior do horizonte fraturado 
encontram-se alterados pelo intemperísmo. Com o alívio de pressão vertical pela erosão, ocorre a geração de juntas de alívio sub-horizontais próximo a superfície, bem como a abertura de fraturas sub-horizontais preexistentes. 


\section{PREENCHIMENTO DE FRATURAS SUB-HORIZONTAIS EM BASALTO}

As fraturas sub-horizontais de grande continuidade lateral em derrames basálticos normalmente se encontram preenchidas. A espessura desse preenchimento varia em média de 0,1 a $3 \mathrm{~mm}$, podendo localmente alcançar até $10 \mathrm{~cm}$ de espessura (Oliveira et al. 1976, Paes de Barros \& Guidicini 1981). O material de preenchimento encontrado nas fraturas subhorizontais de grande continuidade lateral, em geral, é composto de argilas do grupo das esmectitas, calcita, quartzo, zeólitas e fragmentos de basalto brechado, estes muitas vezes intensamente alterados e na fração silto-arenosa (Guidicini \& Campos 1968, Oliveira et al. 1976, Moller \& Souza Pinto, 1976, Björnberg \& Kutner 1983, Serra Jr. et al. 1986).

A composição do material de preenchimento em fraturas pode fornecer indicações sobre sua origem, se proveniente de percolação de fluidos hidrotermais ou simples alteração intempérica, indicando a idade relativa do fraturamento. Adicionalmente, os exames macro e microscópico do material de preenchimento permitem identificar indicadores cinemáticos. Esses indicadores podem corresponder à cristalização de minerais secundários como a calcita, que, ao se desenvolverem concomitante a gênese da fratura, apresentam fibras com direção de crescimento paralelas ao esforço mínimo principal. Estrias de fricção registradas no material de preenchimento indicam a direção da movimentação relativa sobre fraturas preexistentes. Em campo, não foram encontrados sinais de deslocamentos sobre as fraturas analisadas.

Neste trabalho, foram analisadas por difração de raios $\mathrm{X}$ nove amostras de materiais de preenchimento de fraturas sub-horizontais de grande continuidade lateral coletadas nos afloramentos da Usina Hidrelétrica de Água Vermelha (SP-MG) e da pedreira na região de Ribeirão Preto (SP). As análises foram realizadas no Laboratório de Difração de Raios X do Instituto de Geociências da Universidade de São Paulo, no equipamento Siemens D-5000. A preparação das amostras consistiu na moagem do material em gral de ágata e confecção de lâminas delgadas.

Os dados obtidos nas análises das amostras se encontram no Anexo I desta monografia e os resultados foram reunidos na tabela 1. Em meio ao material de preenchimento das fraturas sub-horizontais analisadas foram encontradas predominantemente calcita, quartzo e zeólitas (mordenita e heulandita), e secundariamente, traços de albita e interestratificados de illita e esmectita. 
Tabela 1: Análise mineralógica do material de preenchimento de fraturas sub-horizontais.

\begin{tabular}{|lcc|}
\hline A mostra & Localização & Mineralogia \\
\hline RP-2-01 & Ribeirão Preto & zeólita (mordenita) \\
\hline RP-3-02 & Ribeirão Preto & calcita e quartzo \\
\hline RP-4-03 & Ribeirão Preto & zeólitas (mordenita e heulandita) \\
\hline RP-6-04 & Ribeirão Preto & quartzo e interestratificado de illita e \\
& Água Vermeltita \\
\hline AV-1-05 & Água Vermelha & calcita e traços albita \\
\hline AV-2-06 & Água Vermelha & calcita \\
\hline AV-3-07 & Ribeirão Preto & calcita, zeólitas (mordenita e heulandita) \\
\hline RP-2-08 & Ribeirão Preto & calcita e quartzo de albita \\
\hline RP-1-09 & & \\
\hline
\end{tabular}

A cristalização dos minerais secundários encontrados no preenchimento das fraturas sub-horizontais como zeólitas, quartzo, calcita, albita e argilominerais (interestratificados de illita e esmectita) pode ser atribuída à percolação de fluídos hidrotermais. Esses minerais são comumente encontrados em descontinuidades nos basaltos ou na cimentação de sedimentos da Bacia do Paraná e relacionados aos fluídos gerados na fase tardi-magmática dos derrames, como líquido residual magmático mais evoluído ou proveniente de fontes externas aquecidas (Farjallat \& Suguio 1966, Gomes 1996, Sant'Anna et al. 2006, Duarte 2008, Fernandes et al. 2010a, b). 


\section{CLASSIFICAÇÃO DAS FRATURAS SUB-HORIZONTAIS}

As fraturas sub-horizontais presentes nos derrames basálticos da Formação Serra Geral receberam ao longo dos anos diversas denominações. Com frequência a terminologia adotada nos diferentes trabalhos resultou da interpretação do processo gerador da estrutura. Em decorrência, estas denominações, insistentemente utilizadas, nem sempre se enquadraram adequadamente aos termos apropriados da Geologia Estrutural.

A partir da revisão dos trabalhos que apresentam descrições dos principais tipos de fraturas sub-horizontais presentes nos derrames basálticos da Formação Serra Geral, pôde-se apresentar um quadro com os diferentes tipos de estruturas e uma proposta de nomenclatura mais apropriada. A classificação ora proposta classifica as fraturas horizontais com base nos processos geradores sin- tardi- e pós-magmáticos. O quadro 3 apresenta a classificação das fraturas resumidamente e a figura 63 representa um esquema hipotético de um derrame basáltico com os principais exemplos de ocorrências das fraturas sub-horizontais. O anexo II apresenta uma síntese das principais características das fraturas sub-horizontais localizadas nas usinas hidrelétricas na região sul e sudeste do Brasil, adequadas aos termos propostos nesta dissertação.

\subsection{Fraturas sub-horizontais sin-magmáticas}

As fraturas horizontais sin-magmáticas geralmente estão localizadas em zonas específicas do derrame. Sua localização mais frequente é abaixo da zona vesicular do topo e próximo à base do derrame (e.g. Guidicini \& Ussami 1969, Oliveira 1969, Brito 1971) (figura 63). Essas estruturas são geralmente paralelas ao topo e base do derrame, porém algumas podem apresentar uma mudança brusca de inclinação, normalmente quando associadas a zonas de brechas presentes no topo do derrame (e.g. Oliveira 1969).

As fraturas sub-horizontais sin-magmáticas são caracterizadas como horizontes de grande persistência, até centenas de metros, e de espessura variável, normalmente entre 0,5 e $2 \mathrm{~m}$. Horizontes menos espessos são constituídos por fraturas sub-horizontais curviplanares, pouco persistentes, formando blocos de basalto em forma de lentes com espessura de poucos centímetros. Nos horizontes mais espessos ocorrem fraturas sub-horizontais curviplanares e 
planares com persistência relativamente maior. Essas fraturas são sub-paralelas entre elas, podendo definir uma família de fraturas com espaçamento centimétrico. Este horizonte fraturado define blocos de basalto tabulares e lenticulares (figura 63).

As estruturas que ocorrem na base do derrame são condicionadas pela superfície de deslocamento, capaz de promover um rápido resfriamento e aumento da viscosidade da lava nesta porção. O aumento rápido da viscosidade, somado ao atrito do deslocamento da lava, provoca fraturas de cisalhamento e de contração magmática pelo resfriamento (Guidicini \& Campos 1968, Moler \& Cabrera 1976, Arioli 2008). A estrutura localizada abaixo da zona vesicular do topo do derrame pode também ser gerada pelo esforço causado pelo fluxo na parte interna do derrame (Arioli et al. 2008). Entre o núcleo líquido e a crosta rígida na superfície do derrame existe uma porção visco-elástica sujeita a um cisalhamento rúptildúctil. A gênese das fraturas sub-horizontais estaria relacionada a esforços provenientes do fluxo do próprio derrame.

\subsection{Fraturas sub-horizontais tardi-magmáticas}

As fraturas sub-horizontais tardi-magmáticas constituem verdadeiras juntas de resfriamento. Podem ser caracterizadas juntas sub-horizontais muito persistentes lateralmente, de até dezenas de metros, e pouco onduladas, que ocorrem em diferentes partes do derrame e apresentam preenchimento de espessura de até poucos centímetros (e.g. Moler \& Cabrera 1976, Guidicini 1979) (figura 63). Este tipo de descontinuidade representa a localização da frente de resfriamento em estágios progressivos de resfriamento. As fraturas sub-horizontais tardi-magmáticas também podem ocorrer como horizontes fraturados de grande continuidade lateral, de até centenas de metros, normalmente caracterizados por juntas pouco persistentes, planares e curviplanares, com espaçamento centimétrico, preferencialmente sub-horizontais e com juntas não sistemáticas ortogonais a elas, definindo um horizonte com blocos tabulares e lenticulares de tamanhos variados (figura 63) (e.g. Moller \& Souza Pinto 1976,). A espessura desses horizontes fraturados varia normalmente entre 15 e 40 centímetros (e.g. Moler \& Cabrera 1976).

Os horizontes fraturados normalmente correspondem ao contato entre os níveis colunata e entablamento dos derrames tipo II e III, podendo ser gerados pelo encontro das 
duas frentes de resfriamento ascendente e descendente. Nos casos mais frequentemente observados nos derrames da Formação Serra Geral, o padrão de colunas acima do horizonte fraturado corresponde ao nível de entablamento, formado por disjunções colunares irregulares e estreitas, e o padrão de colunas abaixo do horizonte fraturado corresponde ao nível de colunata, formado por disjunções colunares bem desenvolvidas, como prismas alongados em um sistema hexagonal e nitidamente mais largas que as colunas do nível de entablamento acima (Guidicini 1979, Fernandes et al. 2008, 2010b) (figura 63).

As frentes de resfriamento migram para o interior do derrame paralelamente ao se topo e base (Lyle 2000). Dessa forma, as descontinuidades formadas por essas frentes apresentarão uma ondulação compatível com a ondulação do derrame. No entanto, não é raro que perturbações venham a ocorrer durante a migração dessas frentes. Essas perturbações, geralmente causadas pela infiltração de água superficial logo após o extravasamento da lava, podem acarretar na formação de níveis de entablamento e colunata irregulares, com contatos ramificados e bastante ondulados.

\subsection{Fraturas sub-horizontais pós-magmáticas}

Os eventos pós-magmáticos são responsáveis pela geração de fraturas por alívio de carga e fraturas de cisalhamento (Paes de Barros \& Guidicini 1981), bem como pela deformação, como abertura de juntas e deslocamentos ao longo de fraturas originadas nos eventos sin e tardi-magmáticos, ao longo de contatos litológicos e diferenças texturais no derrame (Guidicini 1979). Ou seja, são eventos passíveis de ocorrer em qualquer litologia. Neste trabalho, seus efeitos são abordados no contexto litológico dos derrames basálticos da Formação Serra Geral. As feições resultantes desses processos são diversas, principalmente devido ao fato de possivelmente ocorrerem ao longo de estruturas preexistentes, que por sua vez já apresentavam um padrão primário característico. Os principais efeitos resultantes de eventos pós-magmáticos consistem na abertura de juntas e geração de fraturas de cisalhamento.

Abertura de juntas de alívio, ocorrendo normalmente sobre descontinuidades subhorizontais preexistentes ou condicionando a formação de juntas sub-horizontais, formam desde uma única junta persistente até uma família de juntas sub-horizontais pouco espaçadas 
(Moler \& Cabrera 1976, Moler \& Souza Pinto 1976, Hasui et al. 1978, Cabrera \& Barbi 1981, Paes de Barros \& Guidicini 1981). Em geral, ocorrem próximo a superfície, até dezenas de metros de profundidade, e acompanham as irregularidade do terreno. A junta pode se apresentar aberta ou preenchida por material de alteração do basalto. Tais estruturas podem ser consideradas como fraturas de distensão, geradas pelo processo de alívio de carga vertical, e são classificadas como juntas de alívio (Dunne \& Hancock 1994).

Feições de cisalhamento podem ocorrer ao longo de fraturas sub-horizontais preexistentes, sin e tardi-magmáticas, ou neoformadas, e serem geradas por processos geomorfológicos ou por esforços tectônicos compressivos. Deslocamentos sobre estruturas preexistentes promovem a cominuição por cisalhamento e estrias de atrito no material de preenchimento proveniente de percolação de fluidos hidrotermais magmáticos (Souza Jr. \& Campos 1987a, b, Serra Jr. et al. 1986, Marques et al. 1987). Falhas neoformadas correspondem a zonas de cisalhamento, definidas por planos de falhas conjugadas de grande continuidade lateral truncadas, com inclinações sub-horizontais até $20^{\circ}$ de mergulho. São caracterizadas como um horizonte fraturado constituído por fraturas ramificadas e entrecruzadas em meio ao basalto maciço ou como horizontes extremamente alterados compostos essencialmente por material silto-arenoso com fragmentos de basalto imbricados e isorientados (figura 63) (Paes de Barros \& Guidicini 1981, Björnberg \& Kutner 1983). 


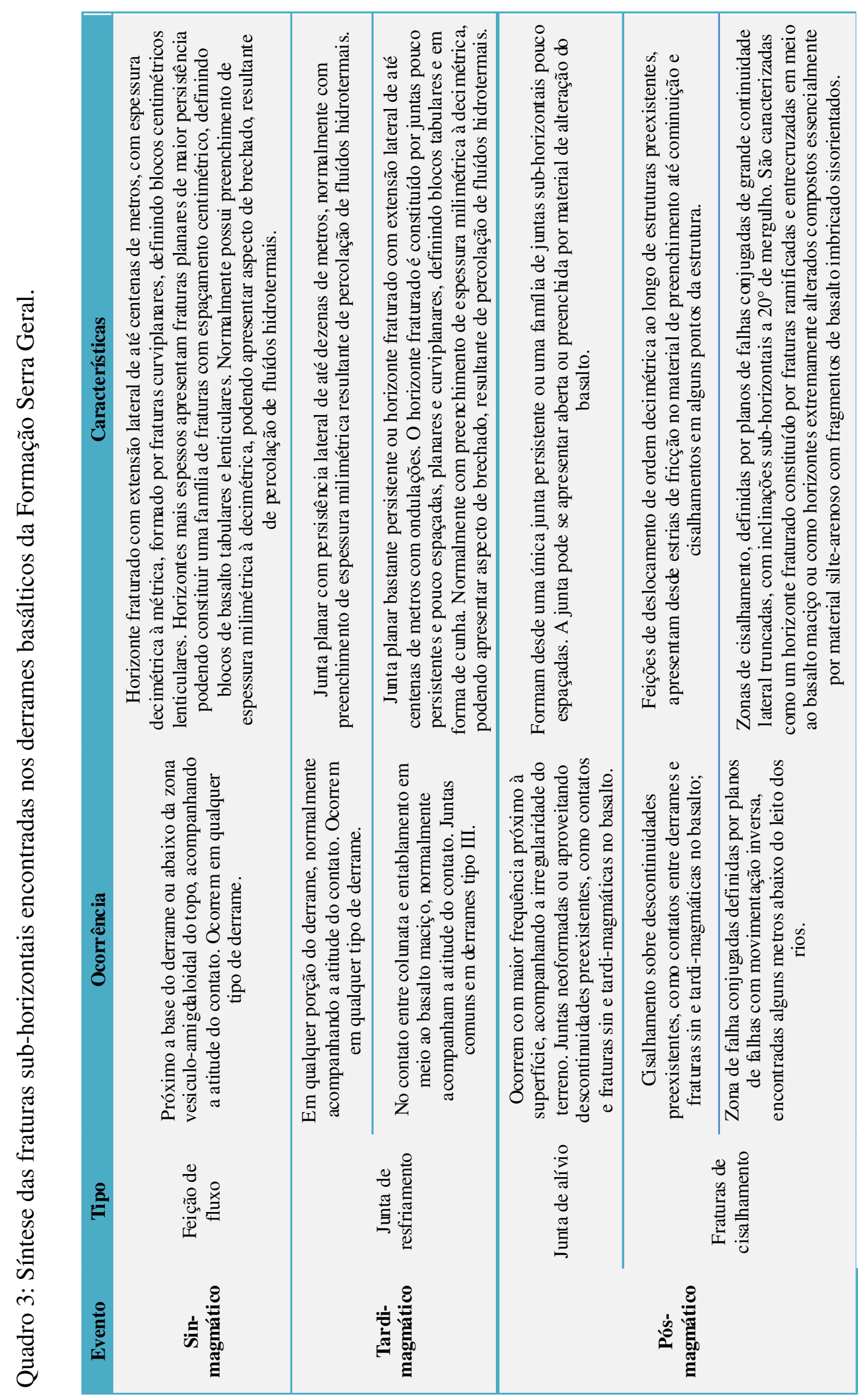




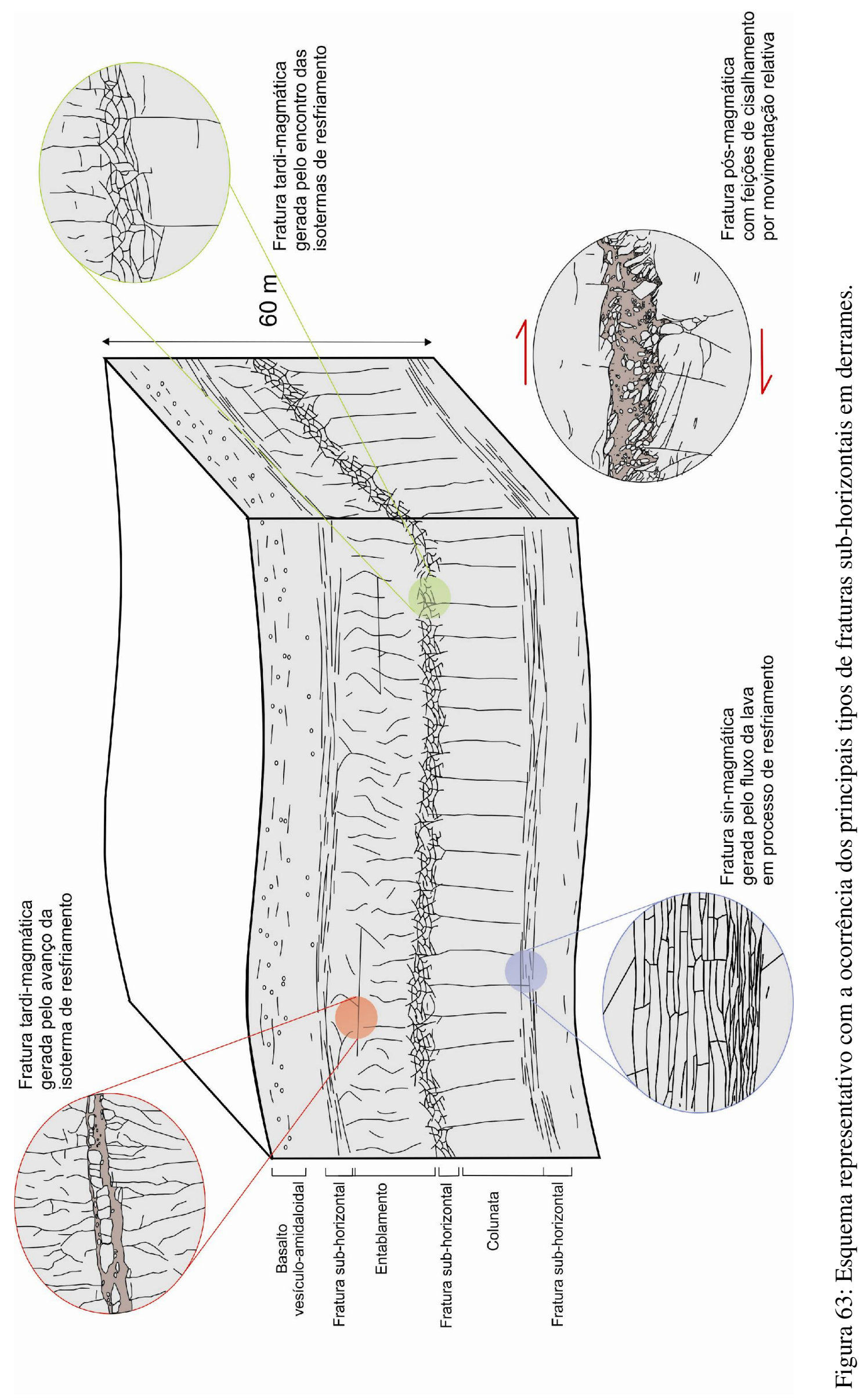




\section{CONSIDERAÇÕES FINAIS}

A evolução dos conhecimentos sobre fraturas sub-horizontais em derrames basálticos ocorreu pela necessidade de compreensão das estruturas que constituíam sérios problemas para a construção de barragens. Embora muitos trabalhos encontrados na literatura abordem de forma mais ampla seus aspectos geotécnicos, descrições mais detalhadas e considerações sobre a gênese das fraturas sub-horizontais também foram apresentadas. No entanto, essas discussões, iniciadas no final da década de 60, praticamente cessaram no inicio da década de 90. A partir de então, são poucas as referências sobre fraturas sub-horizontais em derrames basálticos que contextualizam tais feições e seus possíveis processos geradores.

A partir da revisão de diversos trabalhos publicados no Brasil e no exterior podese apresentar um quadro dos diferentes tipos de fraturas sub-horizontais desenvolvidas em basaltos. As fraturas sub-horizontais foram classificadas neste trabalho de acordo com suas principais características e agrupadas segundo os diferentes processos genéticos apresentados na literatura. As fraturas sub-horizontais sin- e tardi-magmáticas normalmente são encontradas em locais específicos do derrame, além de apresentarem uma correlação com feições primárias do derrame como diferenças texturais e disjunções colunares. A identificação dessas feições é de grande importância para a caracterização das estruturas. Ondulações, ramificações e mudanças bruscas de inclinação que as fraturas sub-horizontais apresentam também podem estar associadas a processos sin- e tardi-magmáticos, seja pela superfície de fluxo irregular, seja por perturbações durante o resfriamento da lava. Neste contexto, a heterogeneidade na textura do basalto e o seu resfriamento diferencial são fatores consideráveis. Tais estruturas podem ser consideradas como feições de fluxo (sin-magmáticas) e fraturas de resfriamento (tardi-magmáticas). Feições de fluxo são estruturas comuns em derrames de lava ácida, devido a sua maior viscosidade. No entanto, muitos trabalhos mencionam a ocorrência dessas estruturas também em derrames de lava básica, normalmente de forma menos expressiva, mas com características semelhantes.

Os processos considerados neste trabalho como pós-magmáticos promovem mudanças nas características primárias das fraturas sin- e tardi-magmáticas, sujeitas a sobreposição de feições. Os fenômenos mais comumente descritos na literatura compreendem a abertura de fraturas pelo alívio de carga, deslocamentos pelo alívio de 
tensões em vales ou eventos tectônicos. Devido à capacidade das fraturas subhorizontais constituírem importantes zonas de percolação de água subterrânea, a intensa alteração a que tais descontinuidades estão sujeitas pode transformá-las em expressivos horizontes de alteração em meio ao derrame.

As referências sobre deslocamentos ao longo de descontinuidades subhorizontais encontradas na literatura apontam como principal evidência estrias de fricção no material de preenchimento. Este fato indica que tais movimentações ocorreram posteriormente à abertura e preenchimento das fraturas, sobre estruturas preexistentes. O material de preenchimento, constituído por minerais secundários oriundos de percolação de fluídos hidrotermais, permite considerar que tais movimentações podem ter ocorrido desde épocas tardias às manifestações vulcânicas, associadas a eventos tectônicos. Fraturas recentes ligadas a processos erosivos são encontradas abertas ou preenchidas por material de alteração do basalto.

Deslocamentos sobre descontinuidade sub-horizontais preexistentes associados ao alívio de tensões laterais em áreas de vales fluviais foram amplamente citados na literatura, com recorrência de feições expressando sentido de movimentação para fora dos taludes. A geração de fraturas conjugadas neoformadas abaixo do leito dos rios também foi foco de discussões associando o fenômeno de alívio de esforços verticais a horizontes fraturados, aos quais fraturas de cisalhamento também podem estar associadas. Com o reconhecimento de fenômenos tectônicos na Bacia do Paraná após o extravasamento dos derrames basálticos da Formação Serra Geral, as fraturas subhorizontais, referidas na literatura como "juntas-falhas", deixaram de ser interpretadas apenas como estruturas resultantes de processos ligados ao fluxo e consolidação do derrame ou ao alívio de tensões em vales fluviais. Tais estruturas também poderiam estar associadas a eventos tectônicos regionais. As hipóteses já apresentadas correlacionaram tais deslocamentos a processos de subsidência, soerguimento e movimentações transcorrentes na bacia. No entanto, as poucas análises estruturais realizadas, empregando métodos adequados para determinação de paleotensões, indicaram uma compatibilidade dos deslocamentos sobre as fraturas sub-horizontais com movimentações tectônicas transcorrentes regionais.

Os conhecimentos sobre geologia estrutural avançaram significativamente desde o final da década de 60, quando o termo "junta-falha" foi proposto. Dessa forma, a 
classificação dos diferentes tipos de fraturas sub-horizontais vem contribuir para o reconhecimento dessas estruturas presentes nos derrames basálticos da Formação Serra Geral, com uma proposta mais atualizada. 


\section{REFERÊNCIAS BIBLIOGRÁFICAS}

Almeida F.F.M. 1986. Distribuição regional e relações tectônicas do magmatismo pósPaleozóico no Brasil. Revista Brasileira de Geociências, 16:325-349.

Almeida F.F.M., Brito Neves B.B., Carneiro C.D.R. 2000. The origin and evolution of the South American Platform. Earth Science Review, 50:77-111.

Angelier J. 1994. Fault slip analysis and paleostress reconstruction. In: Hancock P. L. (ed.). Continental deformation. Pergamon Press, Oxford New York, pp. 53-100.

Araújo J.S. \& Hasui Y. 1985. Estruturas vulcânicas em basaltos no vale do Rio Grande, São Paulo/Minas Gerais. In: V Simpósio Regional de Geologia, São Paulo, SBG, Atas, vol.1, p. 289-300.

Arioli E.E., Licht A.O.B., Vasconcellos E.M.G., Bonnet K.L., Santos E.M. 2008. Faciologia vulcânica da Formação Serra Geral na região de Guarapuava, Paraná. In: IV Simpósio de Vulcanismo e Ambientes Associados, Foz do Iguaçu, SBG, Anais, Cascavel, PR: Coluna do Saber, 2008 (CD-ROM).

Arioli E.E. 2008. Arquitetura faciológica da seqüência vulcânica e o significado exploratório das anomalias geoquímicas de elementos do grupo da platina (egp) e metais associados no sistema magmático Serra Geral, estado do Paraná, Brasil. Tese de Doutorado, Universidade Federal do Paraná, Curitiba, 195 p.

Artur P.C. \& Soares P.C. 2002. Paleoestruturas e petróleo na Bacia do Paraná, Brasil. Revista Brasileira de Geociências, 32:433-448.

Bagolini B. 1971. Osservazioni geologiche e geomorfologiche sugli espandimenti basaltici del bacino dell Alto Paraná nel Brasile Meridionale. Memorie Del Museo Tridentino di Scienze Naturali, 19:71-121.

Barcha S.F. \& Arid F.M. 1975. Origem das cachoeiras da Bacia do Alto Paraná. Revista Brasileira de Geociências, 5:120-135.

Bartorelli A. 1997. As grandes cachoeiras da Bacia do Paraná e sua relação com alinhamentos tectônicos. Tese de Doutorado, Instituto de Geociências e Ciências Exatas, Universidade Estadual Paulista, Rio Claro, 190 p. 
Björnberg A.J.S. \& Meismith C.J. 1975. Problemas geológicos de fundação de barragens sobre basaltos. In: X Seminário Nacional de Grandes Barragens, Curitiba, CBGB, Anais, vol. 1, tema 1, Paper 11.

Björnberg A.J.S. \& Kutner A.S. 1983. Resumo das feições geológicas de interesse às fundações em rocha, em barragens da Bacia do Alto Paraná. In: Simpósio sobre a Geotecnia da Bacia do Alto Paraná, São Paulo, ABGE/ABMS, Anais, vol.1A, p. 263-297.

Bondre N.R., Duraiswami R.A., Dole G. 2004a. Morphology and emplacement of flows from the Deccan Volcanic Province, India. Bulletin of Volcanology, 66:29-45.

Bondre N.R., Duraiswami R.A., Dole G. 2004b. A brief comparison of lava flows from the Deccan Volcanic Province and the Columbia-Oregon Plateau Flood Basalts: Implications for models of flood basalt emplacement. In: Sheth H.C., Pande K. (eds.). Magmatism in India through Time, Proceedings of the Indian Academy of Sciences (Earth and Planetary Sciences), Special Issue, 113:809-817.

Brito S.N.A. 1971. Feições geológicas no basalto da barragem de Volta Grande. In: VII Seminário Nacional de Grandes Barragens, Rio de Janeiro, CBGB, Anais, vol. 1, tema 1 .

Brito S.N.A., Vasconcellos M.L., Geraldo A. 1990. Falhas primárias no basalto da UHE de Nova Ponte e sua influência no projeto. In: VI Congresso Brasileiro de Geologia de Engenharia, Salvador, ABGE, Anais, vol. 1, p. 453-464.

Cabrera J.G. \& Barbi A.L. 1981. Engineering geology of dam foundations on basalt flows of the upper Parana Basin, Brazil. In: Kulhawy F. H. (ed.). Recent development in geotechnical engineering for hydro projects: Embankment dam instrumentation performance, engineering geology aspects, rock mechanics studies. Book Conference Proceedings, ASCE, New York, pp. 177-191.

Camargo F.P., Midea N.F., Nieble C.M., Ruiz M.D. 1971. Características geomecânicas do maciço rochoso de fundação das estruturas de concreto da barragem de Ilha Solteira. In: VII Seminário Nacional de Grandes Barragens, Rio de Janeiro, CBGB, Anais, vol. 1, tema 1. 
Cosgrove J. 1998. The role of structural geology in reservoir characterization. In: Coward M.P., Daltaban T.S., Johnson H. (eds.). Structural geology in reservoir characterization. Geological Society, London, Special Publication, 127:1-13.

De Graff J.M., Aydin A. 1987. Surface morphology of columnar joints and its significance to mechanics and direction of joint growth. Geological Society of America Bulletin, 99:605-617.

Dunne W. M. \& Hancock P. L. 1994. Paleostress analysis of small-scale brittle structures. In: Hancock, P. L. (ed.) Continental deformation. Pergamon Press, Oxford New York, p.101-120.

Duarte L.C. 2008. Evolução geológica, geoquímica e isotópica das mineralizações de geodos com ametista, Artigas, República Oriental do Uruguai. Tese de Doutorado, Instituto de Geociências, Universidade Federal do Rio Grande do Sul, Porto Alegre, 162 p.

Duó A., Silveira J.F.A., Abrão A. 1983. José Ermirio de Moraes (Água Vermelha). In: Simpósio sobre a geotecnia da Bacia do Alto Paraná, São Paulo, ABGE/ABMS, Cadastro geotécnico das barragens da Bacia do Paraná, p. 19.

Dutra C.R., Ferreira C.H.N., Mesquita M.J., Gomes M.E.B., Bongiolo E.M., Arioli E.E. 2008. Variações estruturais e texturais no derrame Salto Segredo, Formação Serra Geral, Paraná. In: IV Simpósio de Vulcanismo e Ambientes Associados, Foz do Iguaçu, SBG, Anais (CD-ROM).

Farjallat J.E.S. \& Suguio K. 1996. Observações sobre a zeolitização em basalto e arenito, Nioaque, Mato Grosso. Boletim da Sociedade Brasileira de Geologia, 15: $51-58$.

Fernandes A.J., Maldaner C., Azevedo Sobrinho J.M., Pressinotti M.M.N, Wahnfried I., Ferreira L.M., Varnier C., Iritani M.A., Hirata R. 2008. Estratigrafia e estruturas dos basaltos da Formação Serra Geral na região de Ribeirão Preto. In: IV Simpósio de Vulcanismo e Ambientes Associados, Foz do Iguaçu, SBG, Anais, Cascavel, PR: Coluna do Saber, 2008 (CD-ROM).

Fernandes A.J., Maldaner C., Azevedo Sobrinho J.M., Pressinotti M.M.N, Wahnfried I. 2010a. Estratigrafia dos derrames de basaltos da Formação Serra Geral (Ribeirão 
Preto - SP) baseada na geologia física, petrografia e geoquímica. Revista do Instituto de Geociências - USP. Geologia USP Série Científica, 10:73-99.

Fernandes A.J., Maldaner C.H., Rouleau A. 2010b. Análise das fraturas nos basaltos de Ribeirão Preto, SP: Aplicação à elaboração de modelo hidrogeológico conceitual. In: XVI Congresso Brasileiro de Águas Subterrâneas, São Luís, ABAS, Anais, 20 p. (CD-ROM).

Fernandes L.A. \& Coimbra A.M. 1996. A Bacia Bauru (Cretáceo Superior, Brasil). Anais da Academia Brasileira de Ciências, 68:195-205.

Ferreira C.H.N., Dutra C.R., Gomes M.E.B., Mesquita M.J., Bongiolo E.M., Arioli E.E. 2008. Características estruturais de um derrame e estratigrafia da região de Salto Segredo. In: IV Simpósio de Vulcanismo e Ambientes Associados, Foz do Iguaçu, SBG, Anais, Cascavel, PR: Coluna do Saber, 2008 (CD-ROM).

Frank H.T., Waichel B.B., Gomes M.E.B., Formoso M.L.L. 2008. Basalt ring structures in lava flows from the Serra Geral Formation at the Água Vermelha dam (São Paulo, Brazil) as collapse structures. In: IV Simpósio de Vulcanismo e Ambientes Associados, Foz do Iguaçu, SBG, Anais, Cascavel, PR: Coluna do Saber, 2008 (CD-ROM).

Frank H.T., Gomes M.E.B., Formoso M.L.L. 2009. Review of the areal extent and the volume of the Serra Geral Formation, Paraná Basin, South America. Pesquisas em Geociências, 36:49-57.

Fulfaro V. J., Perinotto J. A. J. 1994. Geomorfologia do Estado do Mato Grosso do Sul e o arcabouço estrutural. In: XXXVIII Congresso Brasileiro de Geologia, Camburiú, Boletim de Resumos Expandidos, p. 197-198.

Giampá C.E.Q. \& Souza J.C. 1982. Potencial aqüífero dos basaltos da Formação Serra Geral no Estado de São Paulo. In: II Congresso Brasileiro de Águas Subterrâneas, Salvador, Anais, vol.2, p. 3-15.

Goehring L. \& Morris S.W. 2008. Scaling of columnar joints in basalt. Journal of Geophysical Research, 113:B10203. 
Gomes M.E.B. 1996. Mecanismos de resfriamento, estruturação e processos pósmagmáticos em basaltos da Bacia do Paraná - região de Frederico Westphalen $(R S)$, Brasil. Tese de Doutorado, Instituto de Geociências, Universidade Federal do Rio Grande do Sul, Porto Alegre, 219 p.

Gomes R.L. 2001. Características tecnológicas e alterabilidade dos compartimentos entablamento e colunata de derrames basálticos da porção setentrional da Bacia do Paraná. Tese de Doutorado, Escola de Engenharia de São Carlos, Universidade de São Paulo, São Carlos, 295 p.

Guidicini G. \& Campos J.O. 1968. Notas sobre a morfogênese dos derrames basálticos. Boletim da Sociedade Brasileira de Geologia, 17:15-28.

Guidicici G. \& Ussami A. 1969. Controle de subpressão nas fundações da barragem de Jupiá - rio Paraná. In: I Semana Paulista de Geologia Aplicada, São Paulo, APGA, Anais, vol. 2, tema 3, trabalho IV.

Guidicini G. 1979. Juntas horizontais de grande continuidade em derrames basálticos da Bacia do Paraná. In: II Simpósio Regional de Geologia, Rio Claro, SBG, Atas, vol. 2, p. 13-21.

Hamel J.V. 2001. Discussion: Bedding-parallel shear zones as landslide mechanisms in horizontal sedimentary rocks. Environmental \& Engineering Geoscience, 7:217219.

Harding T.P. 1974. Petroleum traps associated with wrench faults. American Association of Petroleum Geologists Bulletin, 58:1290-1304.

Hasui Y., Ponçano W.L., Stein D.P., Melo M.S. 1978. Investigação estrutural na região de Primeiro de Maio, SP e PR. In: II Congresso Brasileiro de Geologia de Engenharia, São Paulo, ABGE, Anais, vol.1, p. 339-352.

Hasui Y. \& Mioto J.A. (eds.) 1992. Geologia estrutural aplicada. ABGE/Votorantim, São Paulo, 459 p.

Infanti Jr. N. 1987. Discussões: Descontinuidades secundárias em maciços basálticos: mecanismos geradores e modelos estruturais. Solos e Rochas - Revista Brasileira de Geotecnia 10:37-38. 
Infanti Jr. N. \& Fornasari Filho N. 1998. Processos de dinâmica superficial. In: Oliveira A.M.S. \& Brito S.N.A. (eds.). Geologia de engenharia. ABGE, São Paulo, pp. 131-152.

Infanti Jr. N., Tassi P.A., Mazzutti R., Piller M., Mafra J.M.Q. 1999. Tensões residuais nas obras subterrâneas da UHT Itá. In: XXIII Seminário Nacional de Grandes Barragens, Belo Horizonte, CBGB, Anais, vol. 2, p. 417-423.

ITAIPU BINACIONAL. 1982. Problemas relacionados com a fundação dos blocos mais altos da barragem de Itaipu. Divisão de geologia, Mecânica de Rochas e Instrumentação, DGMRI-00-065-82, Foz do Iguaçu.

Jerram D.A. \& Widdowson M. 2005. The anatomy of continental flood basalt provinces: geological constraints on the processes and products of flood volcanism. Lithos, 79:355-366.

Kulkarni H., Deolankar S.B. A., Lalwani A., Joseph B., Pawar S. 2000. Hydrogeological framework of the Deccan basalt groundwater systems, westcentral India. Hydrogeology Journal, 8:368-378.

Lastoria G., Sinelli O., Kiang C.H., Hutcheon I., Paranhos Filho A.C., Gastmans D. 2006. Hidrogeologia da Formação Serra Geral no Estado do Mato Grosso do Sul. Águas Subterrâneas, 20:139-150.

Leinz V. 1949. Contribuição à geologia dos derrames basálticos do sul do Brasil. Boletim da Faculdade de Filosofia, Ciências e Letras da Universidade de São Paulo, 5:1-61.

Leinz V., Bartorelli A., Sadowski G. R., Isotta C. A. L. 1966. Sobre o comportamento espacial do trapp basáltico da Bacia do Paraná. Boletim da Sociedade Brasileira de Geologia, 15:79-91.

Lyle P. 2000. The eruption environment of multi-tiered columnar basalt lava flows. Journal of the Geological Society of London, 157:715-722.

Lyle P. (ed.) 2005. A geological excursion guide to the Causeway Coast. Environment and Heritage Service, Department of the Environment, $2^{\circ}$ ed. 
Long P.E., Wood B.J. 1986. Structures, textures and cooling histories of Columbia River basalt flows. Geological Society of America Bulletin, 97:1144-1155.

MacDonald G. A. 1967. Forms and structures of extrusive basaltic rocks. In: Hess H. H. \& Poldervaart A. (eds.). Basalts: The Poldervaart Treatise on Rocks of Basaltic Composition. Interscience Publishers, New York, pp. 1-62.

Machado F.B. 2003. Reologia e possíveis zonas de efusão do magmatismo ácido cretácico da Bacia do Paraná. Trabalho de Formatura, Instituto de Geociências e Ciências Exatas, Universidade Estadual Paulista, Rio Claro, 27 p.

Maciel Filho C.L. (ed.). 2008. Introdução a geologia de engenharia. Santa Maria: editora da UFSM/CPRM, Brasília, $3^{\circ}$ ed., 308 p.

Magalhães F.S., Marques J.D., Serra Jr. E. 1992. Análise estrutural do maciço rochoso de fundação da barragem de Porto Primavera, rio Paraná (SP/MS). In: Hasui Y. \& Mioto J.A. (eds.). Geologia estrutural aplicada. ABGE/Votorantin, São Paulo, pp. 297-311.

Magalhães S.F. \& Cella P.R.C. 1998. Estruturas dos maciços rochosos. In: Oliveira A.M.S. \& Brito S.N.A. (eds.). Geologia de Engenharia. ABGE, São Paulo, pp. 39-55.

Magalhães S.F. 1999. Tensões regionais e locais: casos no território brasileiro e padrão geral. Tese de doutorado, Escola de Engenharia de São Carlos, Universidade de São Paulo, São Carlos, 225 p.

Mano V.G.T. 1987. Estudos Geológicos e geotécnicos das descontinuidades rochosas, "pillow lavas" e paleocanal nos basaltos de fundação da barragem de Nova Avanhandava, rio Tietê (SP). Dissertação de Mestrado, Instituto de Geociências, Universidade de São Paulo, São Paulo, 96 p.

Marques J.D., Magalhães F.S., Serra Jr. E. 1987. Análise das feições estruturais do maciço rochoso nas fundações da barragem de Porto Primavera. In: V Congresso Brasileiro de Geologia de Engenharia, São Paulo, ABGE, Anais, vol. 1, p. 197209. 
Marques L. S. \& Ernesto M. 2004. O magmatismo toleítico da Bacia do Paraná. In: Mantesso Neto V., Bartorelli A., Carneiro C.D.R., Brito Neves B. (eds.). Geologia do continente sul-americano: Evolução da obra de Fernando Flávio Marques de Almeida. Beca, São Paulo, pp. 245-263.

Marques Filho P.L. \& Levis P. 1981. Influência do manto de alteração na barragem de Foz de Areia. In: III Congresso Brasileiro de Geologia de Engenharia, Itapema, ABGE, Anais, vol. 2, p. 73-91.

Marques Filho P. L. \& Geraldo A. 1998. Barragens e reservatórios. In: Oliveira A.M.S. \& Brito S.N.A. (eds.). Geologia de engenharia. ABGE, São Paulo, pp. 397-418.

Marshak S. \& Mitra G. (eds.). 1988. Basic methods of structural geology. Prentice-Hall, Englewood Cliffs, New Jersey, 446 p.

Matheson D.S. \& Thomson S. 1973. Geological Implications of Valley Rebound. Canadian Journal of Earth Sciences, 10:961-978.

Melfi A.J., Piccirillo E.M., Nardy A.J.R. 1988. Geological and magmatic aspects of the Paraná Basin an introduction. In: Piccirillo E.M., Melfi A.J. (eds.) The mezosoic flood volcanism of the Paraná Basin: Petrogenetic and geophysical aspects. Instituto Geofísico, Astronômico e Ciências Atmosféricas (IAG), Universidade de São Paulo, São Paulo, pp. 1-13.

Melo M.M. 2010. Caracterização e compartimentação geológica e geomecânica de maciço basáltico heterogêneo, aplicados a engenharia. Dissertação de Mestrado, Instituto de Geociências, Universidade de São Paulo, São Paulo, 160 p.

Midea N.F. \& Cury Jr A. 1975. Experiências na avaliação do estado de tensão em maciços rochosos. In: X Seminário Nacional de Grandes Barragens, Curitiba, CBGB, Anais, vol. 1, tema 1, Paper 7.

Midea N.F., Fujimura F., Paula L.C. 1975. Observações sobre a necessidade de ensaios in situ para a caracterização da resistência ao cisalhamento de estruturas tipo junta em derrames basálticos. In: X Seminário Nacional de Grandes Barragens, Curitiba, CBGB, Anais, vol. 1, tema 1, Paper 9. 
Milani E.J. 1997. Evolução tectono-estratigráfica da Bacia do Paraná e seu relacionamento com a geodinâmica fanerozóica do Gondwana sul-ocidental. Tese de Doutoramento, Instituto de Geociências, Universidade Federal do Rio Grande do Sul, Porto Alegre, 255 p.

Milani E. J., Ramos V. A. 1998. Orogenias paleozóicas do domínio sul-oriental do Gondwana e os ciclos de subsidência da Bacia do Paraná. Revista Brasileira de Geociências, 28:473-484.

Milani E.J. 2004. Comentários sobre a origem e a evolução tectônica da Bacia do Paraná. In: Mantesso-Neto V., Bartorelli A., Carneiro C.D.R., Brito Neves B.B. (eds.) Geologia do continente sul-americano: Evolução da obra de Fernando Flávio Marques de Almeida. Becca, São Paulo, pp. 265-279.

Mioto J.A. \& Coelho L.F.M. 1998. Estado de tensões dos maciços rochosos. In: Oliveira A.M.S. \& Brito S.N.A. (eds.). Geologia de engenharia. ABGE, São Paulo, pp.153-161.

Moller W.A. \& Cabrera J.G. 1976. Características de fundações sobre rochas basálticas. In: I Congresso Brasileiro de Geologia de Engenharia, Rio de Janeiro, ABGE, Anais, vol. 2, p. 197-216.

Moller W.A. \& Souza Pinto A. 1976. Influência das irregularidades na resistência ao cisalhamento de uma junta horizontal em basalto; Caso da tomada d'água da barragem de São Simão. In: I Congresso Brasileiro de Geologia de Engenharia, Rio de Janeiro, ABGE, Anais, vol. 2, p. 431-452.

Moura Filho O., Sorregotte C. 1975. Prospecção do maciço rochoso para fundação das estruturas de concreto, Usina de Água Vermelha - Rio Grande. In: X Seminário Nacional de Grandes Barragens, Curitiba, CBGB, Anais, vol. 2, tema 4, Paper 8.

Nardy A.J.R., Oliveira M.A.F., Betancourt R.H.S., Verdugo D.R.H., Machado F.B. 2002. Geologia e estratigrafia da Formação Serra Geral. Revista Geociências UNESP, 21:15-32.

Nardy A.J.R., Machado F.B., Oliveira M.A.F. 2008. As rochas vulcânicas mesozóicas ácidas da Bacia do Paraná: litoestratigrafia e considerações geoquímicoestratigráficas. Revista Brasileira de Geociências, 38:178-195. 
Nichols Jr. T.C. 1980. Rebound, its nature and effect on engineering works. Quarterly Journal of Engineering Geology, 13:133-152.

Nieble C.M. 1983. Escavação em rocha para fundações de barragens. In: Simpósio sobre a Geotecnia da Bacia do Alto Paraná, São Paulo, ABGE/ABMS, Anais, vol. 1A, p. 401-416.

Nieble C.M., Takahashi H., Bertin Neto S., Valério A. 1974a. Sobre o deslocamento de paredes de escavações em maciços basálticos. In: V Congresso Brasileiro de Mecânica dos Solos, São Paulo, ABMS, Anais, vol.1, p. 373-382.

Nieble C.M., Midea N.F., Fugimura F., Neto S.B. 1974b. Shear strenght of typical feature of basaltic rock masses - Paraná Basin - Brazil. In: III Congress of the International Society for Rock Mechanics, Denver, Proceedings, vol. 2, p. 294301.

Oliveira A.M.S. 1969. Aspectos geológicos do derrame basáltico principal da barragem de Ilha Solteira - rio Paraná. In: I Semana Paulista de Geologia Aplicada, São Paulo, APGA, Anais, vol. 2, tema 3, trabalho II.

Oliveira A.M.S., Silva R.F., Guidicini G. 1976. Comportamento hidrogeotécnico dos basaltos em fundações de barragens. In: I Congresso Brasileiro de Geologia de Engenharia, Rio de Janeiro, ABGE, Anais, vol. 2, p. 413-29.

Oliveira A.M.S. \& Brito S.N.A. (eds.). 1998. Geologia de Engenharia. ABGE, São Paulo, 513 pp.

Paes de Barros F. \& Guidicini G. 1981. Um processo natural de alívio de tensões e o projeto de drenagem das fundações da barragem de Itaipu. In: XIV Seminário Nacional de Grandes Barragens, Recife, CBGB, Anais, vol.1, tema 1, p. 519539.

Pan E., Amadei B., Savage W.Z. 1995. Gravitational and tectonic stresses in anisotropic rock with irregular topography. International Journal of Rock Mechanics and Mining Science \& Geomechanics Abstracts, 32:201-214. 
Patton F.D. \& Hendron A.J.F. 1974. General report on mass movements.In: II International Congress of the International Association of Engineering Geology, São Paulo, ABGE, Proceedings, vol.2, tema 5, V-GR.

Peate D.W., Mantovani M.S.M., Hawkesworth C. 1992. Chemical Stratigraphy of the Paraná Lavas (South America): classification of magma types and their spatial distribution. Bulletin of Volcanology, 55:119-139.

Piccirillo E.M. \& Melfi A.J. (eds.) 1988. The mesozoic flood volcanism of the Paraná Basin: Petrogenetic and geophysical aspects. Instituto Geofísico, Astronômico e Ciências Atmosféricas (IAG), Universidade de São Paulo, São Paulo, 600 p.

Pinheiro R.J.B. \& Soares J.M.D. 2004. Condicionantes geológicos-geotécnicos de movimentos de massa na encosta da Serra Geral - RS. Teoria e Prática na Engenharia Civil, 4:59-68.

Pollard D.D. \& Aydin A. 1988. Progress in understanding jointing over the past century. Geological Society of America Bulletin, 100:1181-1204.

Price N.J. \& Cosgrove J.W. (eds.) 1990. Analysis of Geological Structures. Cambridge University Press, Cambridge, New York, 502 p.

Ramsay J.G. \& Huber M.I. (eds.). 1987. The techniques of modern structural geology. Volume 2: Folds and fractures. Academic Press, London, 700p.

Rebouças A.C. 1978. Potencialidades hidrogeológicas dos basaltos da Bacia do Paraná no Brasil. In: XX Congresso Brasileiro de Geologia, Recife, Anais, vol. 6, p. 2963-2976.

Rebouças A.C. \& Fraga C.G. 1988. Hidrogeologia das rochas vulcânicas do Brasil. Revista de Águas Subterrâneas, 12:29-55.

Renne P.R., Ernesto M., Pacca I.G., Coe R.S., Glen J.M., Prévot M., Perrin M. 1992. The age of Paraná flood volcanism, rifting of Gondwanaland and the JurassicCretaceous boundary. Science, 258:975-979.

Riccomini, C. 1995. Tectonismo gerador e deformador dos depósitos pós-gondvânicos da porção centro-oriental do Estado de São Paulo e áreas vizinhas. Tese de 
Livre-Docência, Instituto de Geociências, Universidade de São Paulo, São Paulo, 100 p.

Riccomini, C. 1997a. Arcabouço estrutural e aspectos do tectonismo gerador e deformador da Bacia Bauru no estado de São Paulo. Revista Brasileira de Geociências, 27:153-162.

Riccomini, C. 1997b. Considerações sobre a posição estratigráfica e tectonismo deformador da Formação Itaqueri na porção centro-leste do Estado de São Paulo. Revista do Instituto Geológico, 18: 41-48.

Rostirolla S.R., Assine M.L., Fernandes L.A., Artur P.C. 2000. Reativação de paleolineamentos durante a evolução da Bacia do Paraná - o exemplo do Alto Estrutural de Quatiguá. Revista Brasileira de Geociências, 30:639-648.

Sallun A. E. M., Suguio K., Stevaux J. C. 2007. Proposição formal do alogrupo Alto Rio Paraná (SP, PR e MS). Geologia USP Série Científica, 7:49-70.

Sant'Anna L.G., Clauer N., Cordani U.G., Riccomini C., Velázquez V.F., Liewig N. 2006. Origin and migration timing of hydrothermal fluids in sedimentary rocks of the Paraná Basin, South America. Chemical Geology, 230:1-21.

Self S., Thordarson T., Keszthelyi L.P. 1997. Emplacement of continental flood basalt lava flows. In: J.J. Mahoney \& M.F. Coffin (eds.). Large igneous provinces; continental, oceanic, and planetary flood volcanism. American Geophysical Union, Washington, Geophysical Monograph 100:381-410.

Serra Jr. E., Magalhães F.A., Azevedo A.A. 1986. Análise de feições estruturais para estudo do estado de tensões naturais no maciço basáltico da UHE Taquaruçu. In: II Simpósio Sul Americano de Mecânica de Rochas, Porto Alegre, ABMS/CBMR, Anais, vol. 2, p. 252-262.

Sibson R. 1977. Fault rocks and fault mechanisms. Journal of the Geological Society, 133:191-213.

Smith R.P. 2004. Geologic setting of the Snake River Plain aquifer and vadose zone. Vadose Zone Journal, 3:47-58. 
Soares P.C. 1974. Elementos estruturais da parte nordeste da Bacia do Paraná: classificação e gênese. In: XXVIII Congresso Brasileiro de Geologia, Porto Alegre, SBG, Anais, vol. 4, p. 107-121.

Souza Jr. N.N. 1986. Feições lito-estruturais de interesse geológico e geotécnico em maciços basálticos. Dissertação de Mestrado, Escola de Engenharia de São Carlos, Universidade de São Paulo, São Carlos, 183 p.

Souza Jr. N.N. \& Campos J.O. 1987a. Descontinuidades secundárias em maciços basálticos: mecanismos geradores e modelos estruturais. Solos e Rochas Revista Brasileira de Geotecnia, 10:9-17.

Souza Jr. N.N. \& Campos J.O. 1987b. Falhas horizontais em derrames basálticos. In: V Congresso Brasileiro de Geologia de Engenharia, São Paulo, ABGE, Anais, vol. 1, p. 61-69.

Souza Jr. N.N. \& Campos J.O. 1990. Sub-horizontal discontinuities of large extension in the basaltic lava-flows nucleus of the Paraná Basin (Brazil) - In: Barton N. \& Stephansson O. (eds.). Rock Joints. Rotterdam Brookfield, Balkema, pp. 97-100.

Souza Jr. N.N. 1992. O “entablamento” em derrames basálticos da Bacia do Paraná: aspectos genéticos e caracterização geotécnica. Tese de Doutorado, Escola de Engenharia de São Carlos, Universidade de São Paulo, São Carlos, 257 p.

Spry A.H. 1962. The origin of columnar jointing, particularly in basalt flows. Journal of the Geological Society of Australia, 8:191-216.

Thordarson T. \& Self S. 1998. The Roza Member, Columbia River Basalt Group: a gigantic pahoehoe lava flow field formed by endogenous processes? Journal of Geophysical Research, 103:27411-27445.

Tomkeieff S.I. 1940. The basalt lavas of the Giant's Causeway district of Northern Iceland. Bulletin of Volcanology, 2:89-143.

Tressoldi M. 1987. Aspectos hidrogeológicos dos derrames basálticos das fundações das estruturas de concreto da Usina de Porto Primavera. In: V Congresso Brasileiro de Geologia de Engenharia, São Paulo, ABGE, Anais, vol.1, p. 357372. 
Turner S., Regelous M., Kelley S., Hawkesworth C., Mantovani M.S.M. 1994. Magmatism and continental break-up in the south atlantic: high precision ${ }^{40} \mathrm{Ar}$ ${ }^{39}$ Ar geochronology. Earth and Planetary Science Letters, 121:333-348.

Ussami A., Mano V.G.T., Bispo D.H. 1976. Considerações sobre a fundação dos vertedouros da Usina Hidrelétrica de Água Vermelha. In: XI Seminário Nacional de Grandes Barragens, Fortaleza, CBGB, Anais, vol. 2, tema 2, paper 5.

Waichel B.L. 2006. Estruturação de derrames e interações lava-sedimento na porção central da Província Basáltica Continental do Paraná. Tese de Doutorado, Instituto de Geociências, Universidade Federal do Rio Grande do Sul, Porto Alegre, 285 p.

Walker G.P.L. 1971. Compound and simple lava flows and flood basalts. Bulletin of Volcanology, 35:579-590.

Wernick E. \& Souza A. 1971. Sobre a ocorrência de uma camada de fluxo (flow layer) em basaltos na região de Salto de Avanhandava, Estado de São Paulo. Anais da Academia Brasileira de Ciências, 43:421-427.

Weaver K.D. \& Bruce D. A. (eds.). 2007. Dam foundation grouting. ASCE, Reston, $3^{\circ}$ ed., $473 \mathrm{p}$.

Zalán P.V., Wolf S., Astolfi M.A., Vieira I.S., Conceição J.C.J.. Appi V.T., Neto E.V.S., Cerqueira J.R., Marques A. 1990. The Paraná Basin, Brazil. In: Leighton M.W., Kolata D.R., Oltz D.F., Eidel J.J. (eds.). Interior cratonic basins. American Association of Petroleum Geologists Memoir, Tulsa, 51, p. 681-708.

Zhao G. \& Johnson A.M. 1992. Sequence of deformation recorded in joints and faults, Arches National Park, Utah. Journal of Structural Geology, 14:225-236. 
Anexo I

Difratogramas das análises do material de preenchimento das fraturas sub-

horizontais 


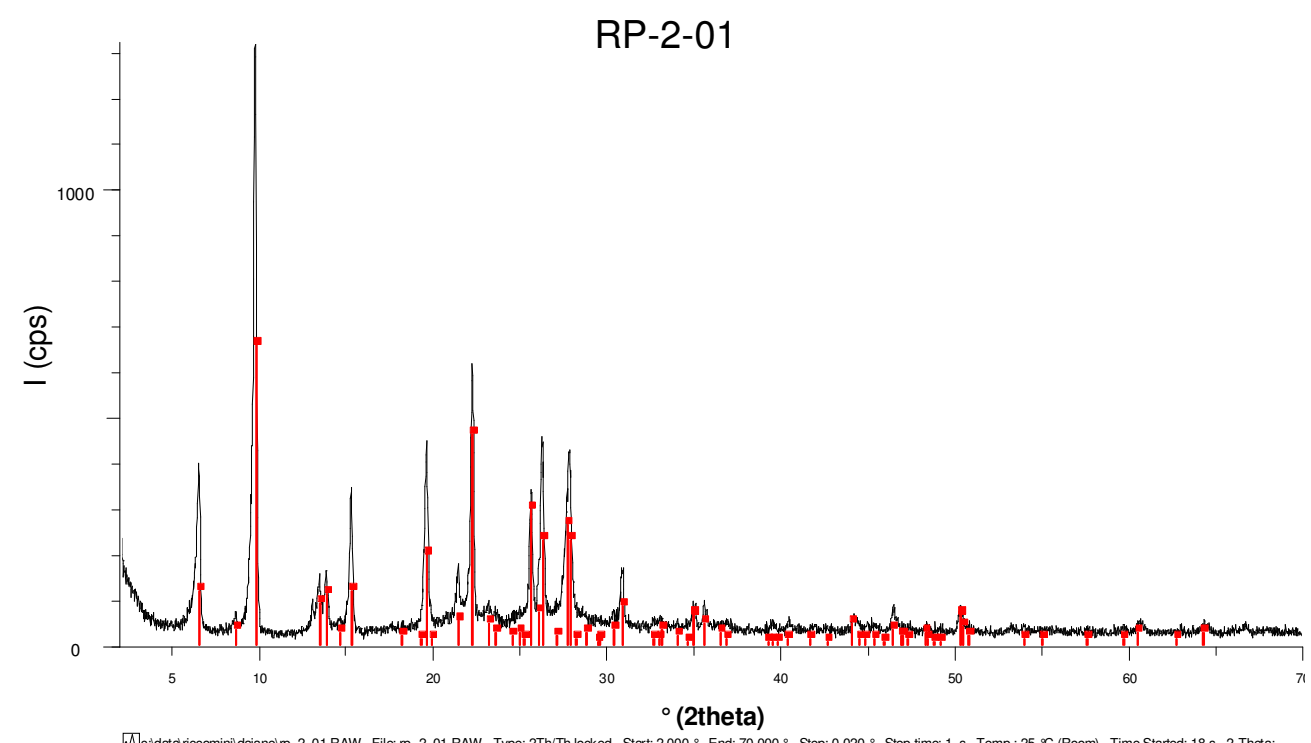

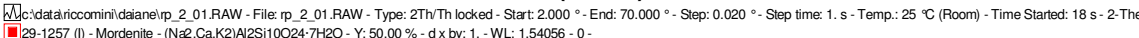

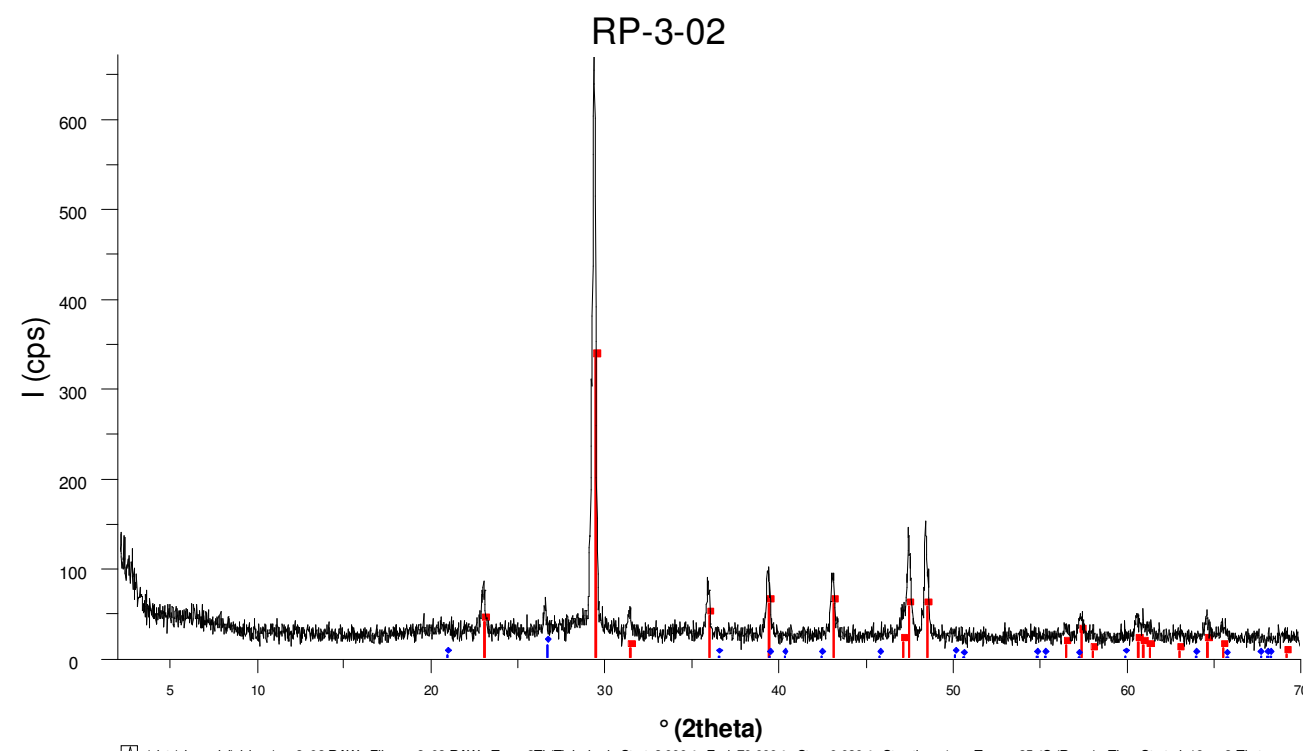

Wcidata

2000 - End: $70.000^{\circ}$ - Step: $0.020^{\circ}$ - Step time: 1. s - Temp.: $25^{\circ}$ (Room) - Time Started: 18 s - 2-Theta: - $46-1045$ (") - Quartz, syn- SiO2-Y: $2.08 \%$ - dx by: 1. - WL: 1.54056 - - - VIC PDF 3.4- S-Q 2.4\%. 
RP-4-03

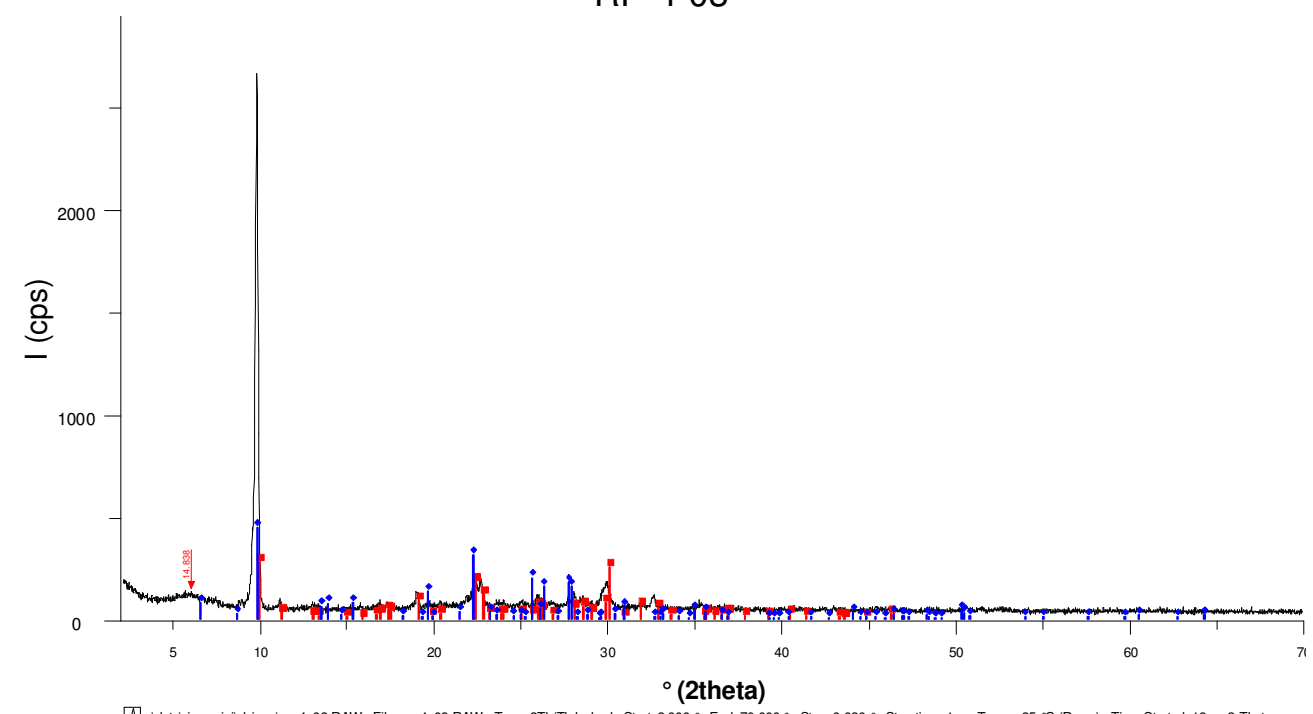

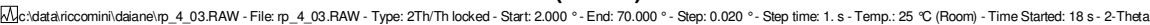

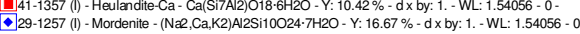

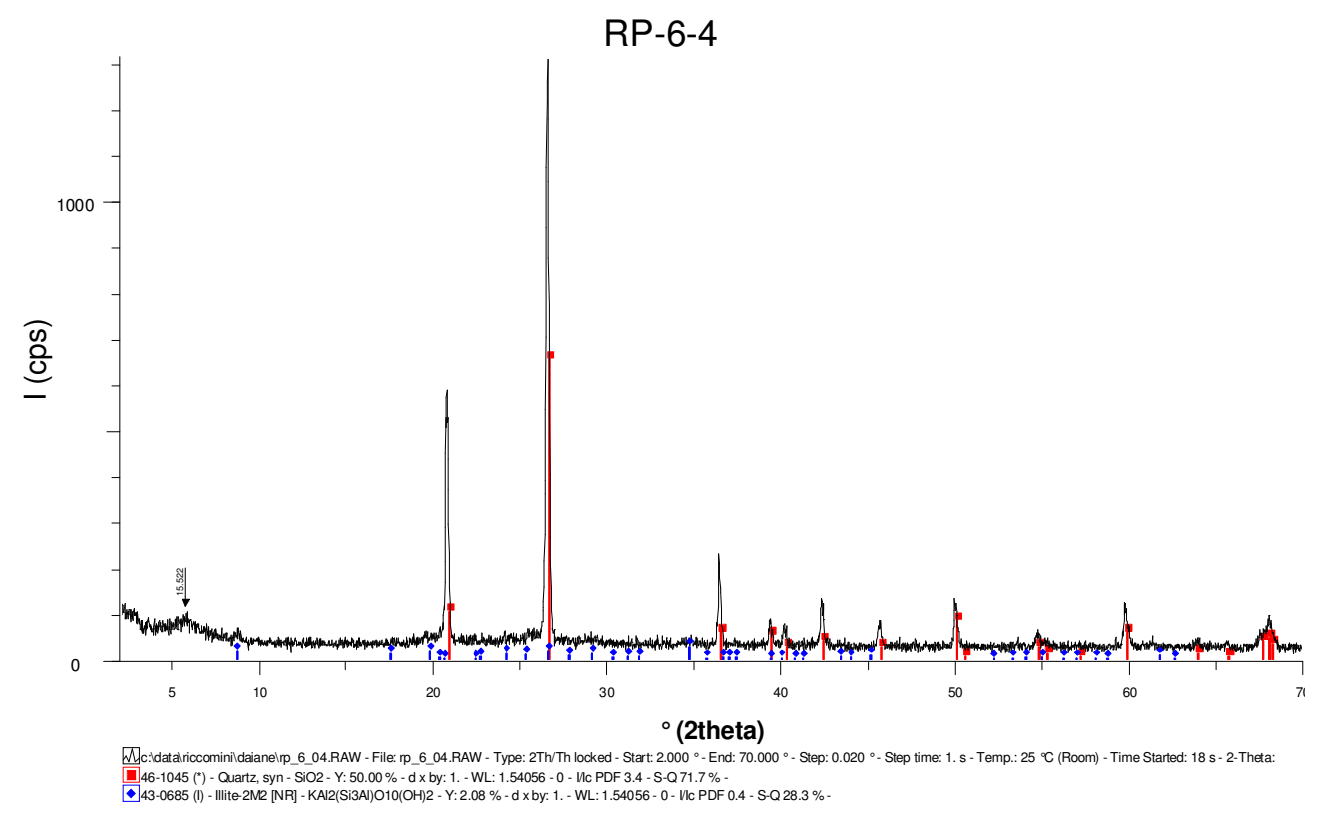




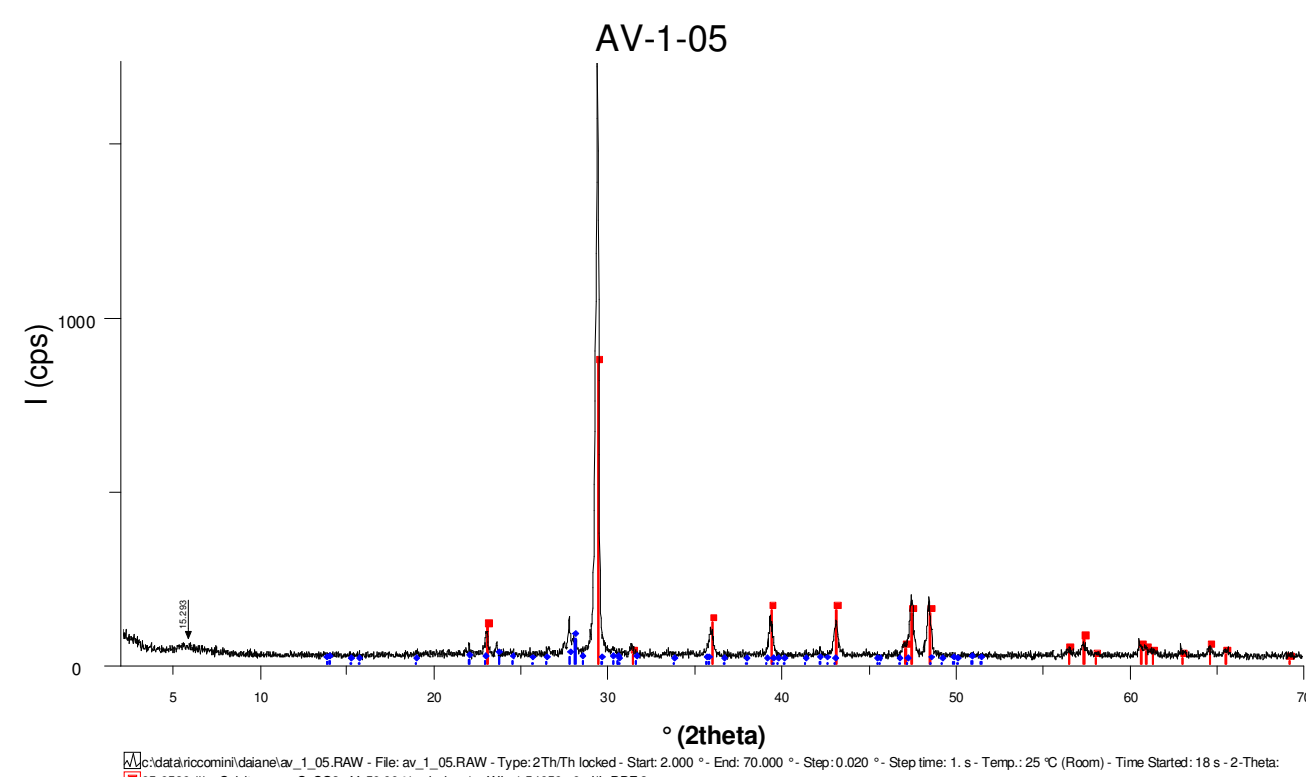

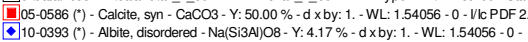

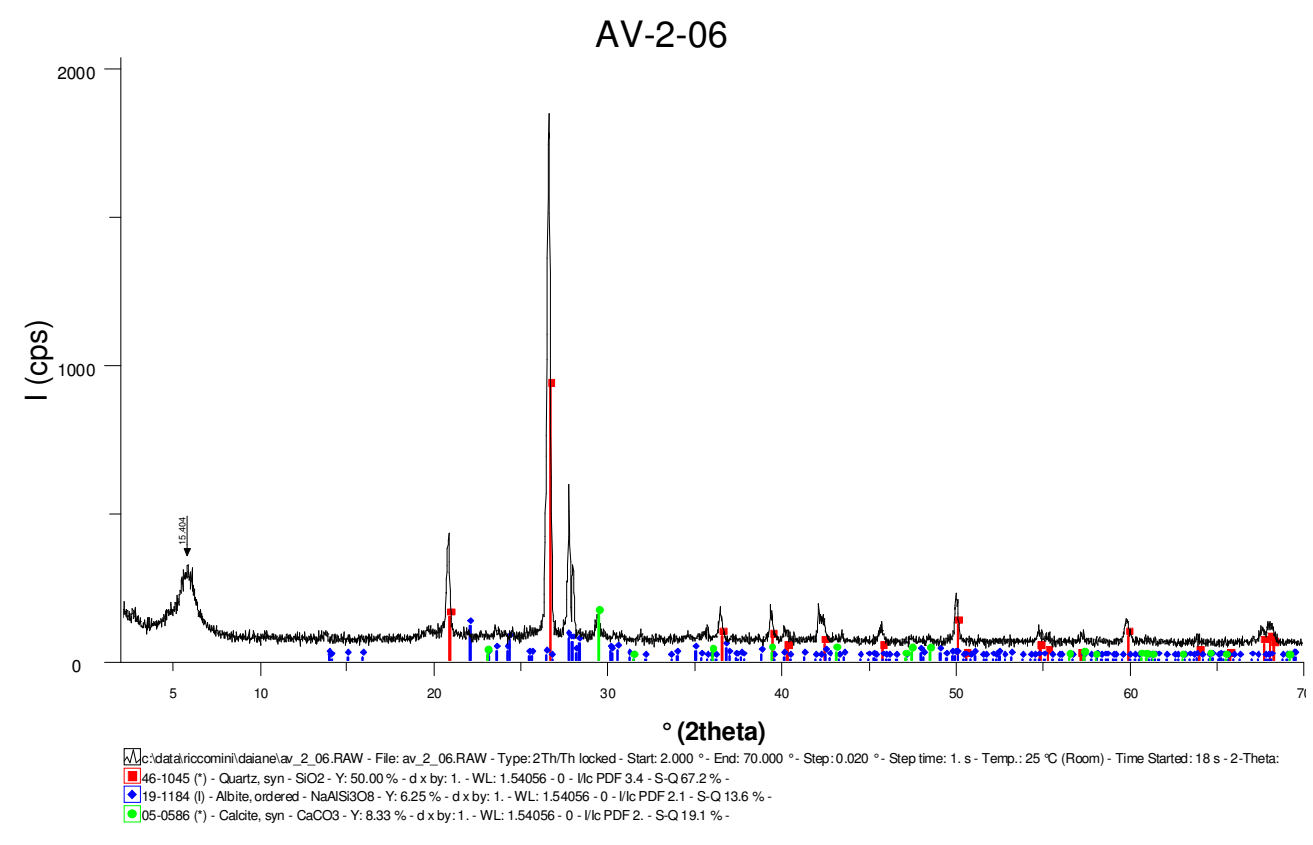




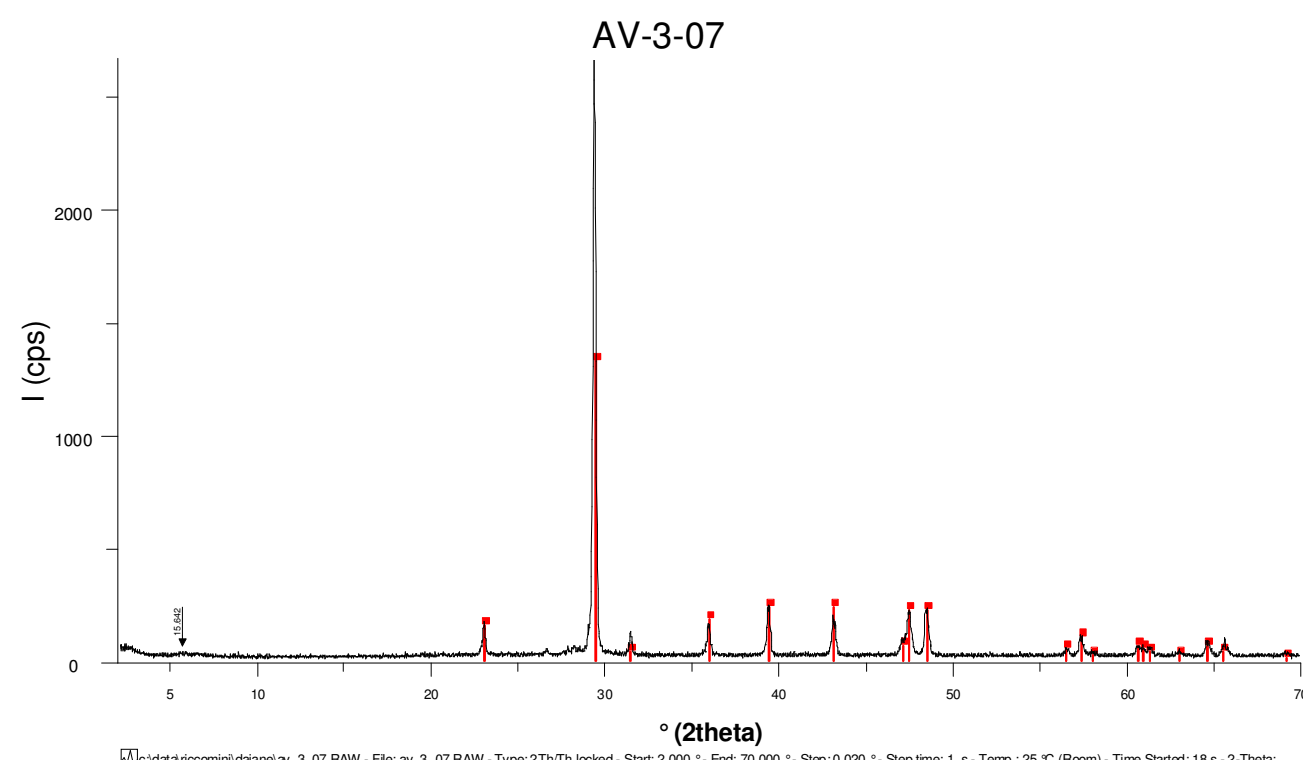

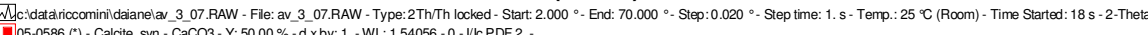
$\square 05-0586$ (") - Calcite, syn - CaCO3 - Y: 50.00\% - d x by: 1. - WL: 1.54056 - 0 - VIc PDF 2 -

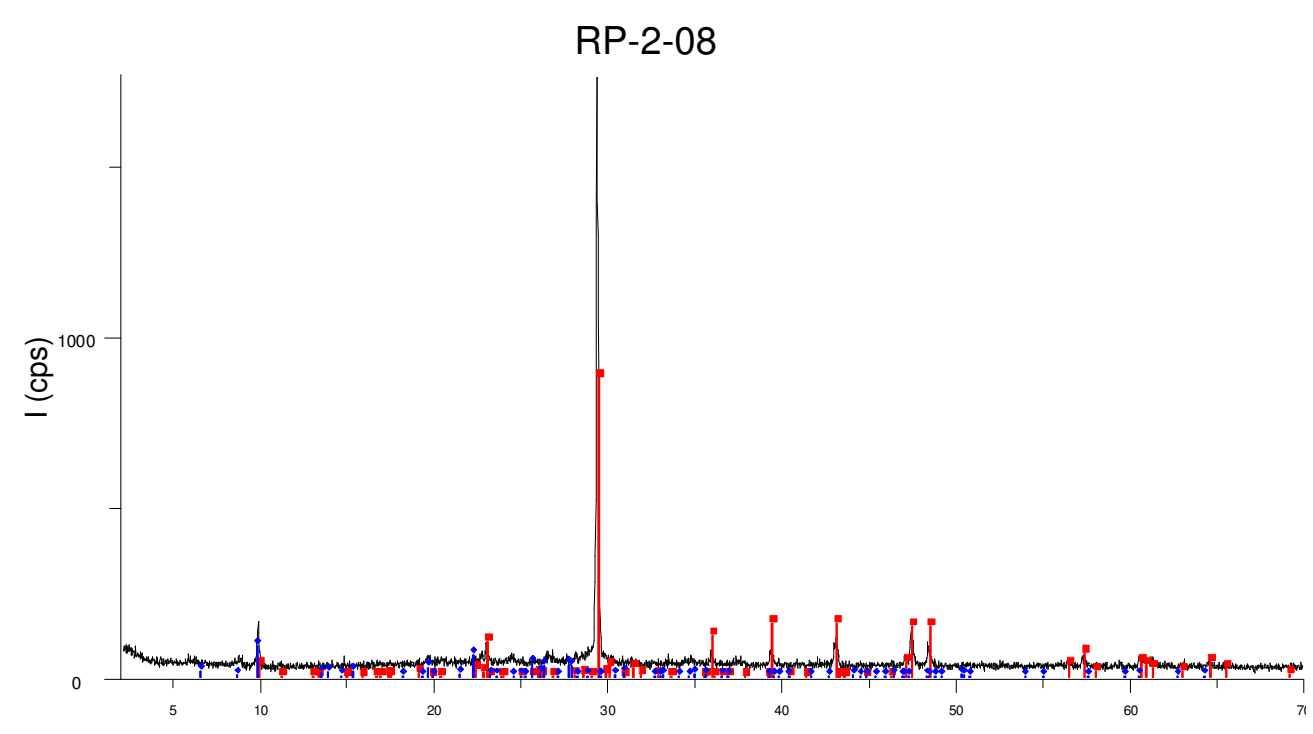

${ }^{\circ}$ (2theta)

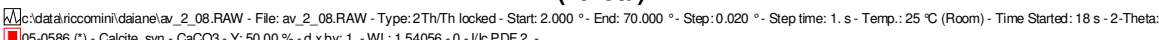

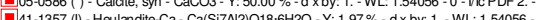

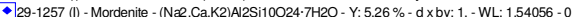




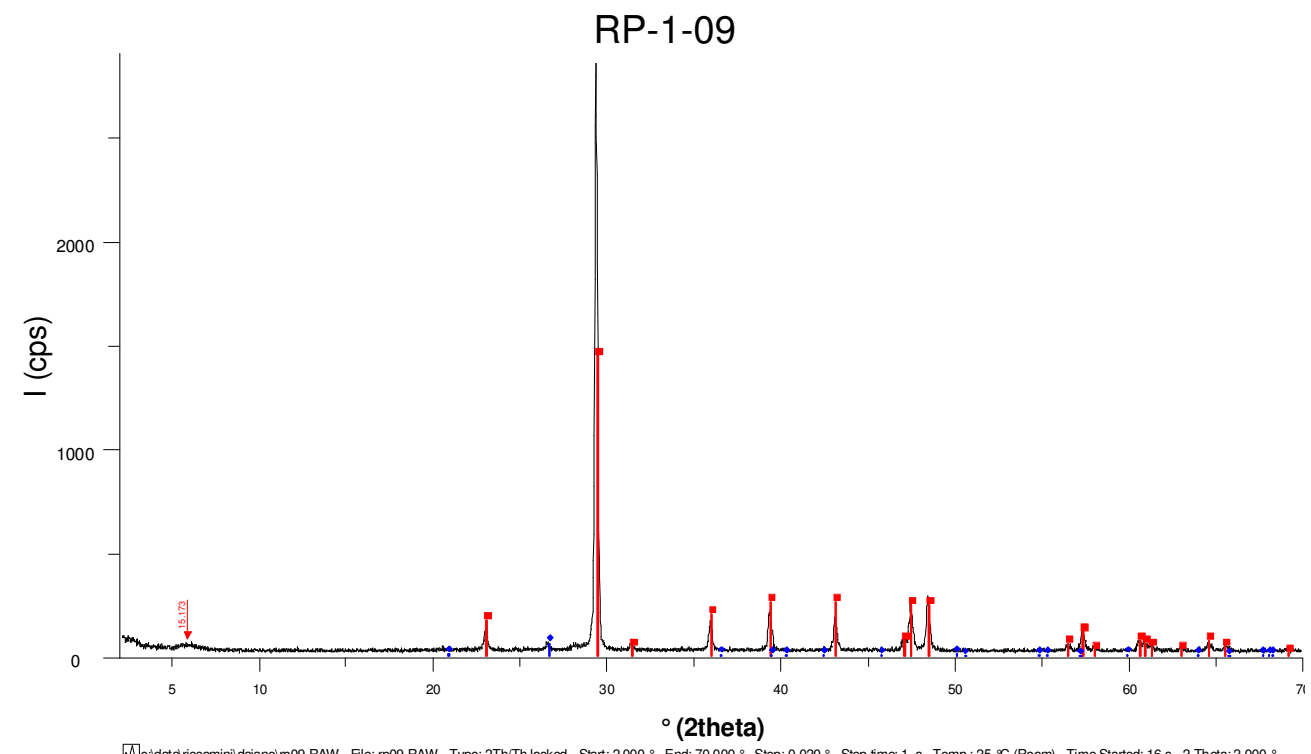

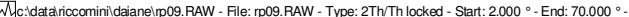

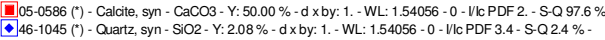


Anexo II

Síntese das principais características das fraturas sub-horizontais localizadas nas usinas hidrelétricas na região sul e sudeste do Brasil 


\begin{tabular}{|c|c|c|c|}
\hline Localização & $\begin{array}{c}\text { Espessura } \\
\text { do derrame }\end{array}$ & Características principais & Referência \\
\hline $\begin{array}{c}\text { Usina } \\
\text { Hidrelétrica de } \\
\text { Itaipu (PR) }\end{array}$ & 40 metros & $\begin{array}{l}\text { Abaixo do leito do rio ocorrem diversas descontinuidades de mergulho variando entre sub-horizontal e } \\
20^{\circ} \text {. Algumas estruturas compreendem juntas de alívio pós-magmáticas, caracterizadas como uma única } \\
\text { junta aberta ou preenchida por material de alteração e silte. Essas estruturas aproveitam o contato entre } \\
\text { os derrames (“A” e "B") e ocorrem na base do basalto vesículo-amidaloidal do topo do derrame "A", } \\
\text { aproveitando a diferença textural do basalto denso e vesiculado. } \\
\text { Na base do derrame "B" ocorre um horizonte fraturado de grande extensão lateral que pode estar } \\
\text { associado ao fluxo da lava (fratura sin-magmática). Esta estrutura possui espessura variável, fraturas de } \\
\text { curta extensão lateral definindo blocos tabulares. Em geral, se encontram fechadas, oxidadas e muitas } \\
\text { vezes com película de argila amarela, possivelmente originada por fluídos tardios à consolidação do } \\
\text { derrame. No entanto, abaixo do leito do rio, este horizonte fraturado na base do derrame "B" se } \\
\text { intensifica, aumentando consideravelmente sua espessura. Neste local não ocorre preenchimento por } \\
\text { argila ou sinais de alteração e nos planos das fraturas verifica-se a presença de estrias. Neste caso, a } \\
\text { estrutura parece corresponder a uma fratura de cisalhamento pós-magmática que, em parte, aproveitou a } \\
\text { descontinuidade preexistente no basalto. } \\
\text { O derrame "B" apresenta cinco zonas de cisalhamento definidas como horizontes fraturados, com maior } \\
\text { ou menor grau de alteração, que parecem corresponder a fraturas de cisalhamento neoformadas pós- } \\
\text { magmáticas. Estes horizontes apresentam duas direções preferenciais e inclinação entre sub-horizontal e } \\
20^{\circ} \text { e rejeitos decimétricos. Tais estruturas apresentam grande variação de características como: fraturas } \\
\text { ramificadas e entrecruzadas sem preenchimento e sem sinais de alteração; horizonte muito fraturado } \\
\text { horizontalmente definindo blocos tabulares com película de argila e preenchimento parcial; horizontes } \\
\text { de rocha fragmentada que varia a proporção de argila, ora compostos por fragmentos angulosos de } \\
\text { basalto e pouca argila, ora com preenchimento exclusivamente argiloso. A ocorrência dessa argila pode } \\
\text { estar associada ao maior e menor grau de alteração do horizonte fraturado. }\end{array}$ & $\begin{array}{r}\text { Moller \& Cabrera } \\
\text { (1976), Paes de Barros \& } \\
\text { Guidicini (1981), } \\
\text { ITAIPU BINACIONAL } \\
\text { (1982), Björnberg \& } \\
\text { Kutner (1983) }\end{array}$ \\
\hline $\begin{array}{c}\text { Usina } \\
\text { Hidrelétrica de } \\
\text { Capivara (SP- } \\
\text { PR) }\end{array}$ & & $\begin{array}{l}\text { Neste local ocorre um horizonte fraturado de dezenas de centímetros até } 2 \text { metros de espessura de rocha } \\
\text { totalmente alterada e intensamente fraturada. Ao longo dessa estrutura foi observado um deslocamento } \\
\text { de } 10 \text { a } 20 \mathrm{~cm} \text { durante a obra, sendo observadas em alguns locais pequenas estrias de fricção sem direção } \\
\text { preferencial. Esta estrutura parece corresponder a uma fratura de cisalhamento pós-magmática em que o } \\
\text { cisalhamento se deu sobre uma estrutura preexistente, devido ao alívio lateral das tensões com o corte do } \\
\text { talude. }\end{array}$ & Nieble et al. (1974a) \\
\hline
\end{tabular}




\begin{tabular}{|c|c|c|c|}
\hline Localização & $\begin{array}{c}\text { Espessura } \\
\text { do derrame }\end{array}$ & Características principais & Referência \\
\hline $\begin{array}{c}\text { Usina } \\
\text { Hidrelétrica de } \\
\text { Foz de Areia } \\
\text { (PR) }\end{array}$ & 20 metros & $\begin{array}{l}\text { O basalto maciço pouco alterado que ocorre no leito do rio apresenta juntas de alívio com sinais de } \\
\text { alteração e horizontes sub-horizontais de espessura entre } 5 \text { e } 30 \mathrm{~cm} \text {, compostos por rocha extremamente } \\
\text { fraturada, fragmentada, com aspecto cisalhado e com presença de material de alteração, o qual diminui } \\
\text { de intensidade com a profundidade. Os horizontes fraturados possuem mergulho entre } 20 \text { e } 25^{\circ} \text { para } \\
\text { ambas as margens. Essas estruturas correspondem a fraturas de cisalhamentos pós-magmáticas } \\
\text { neoformadas, pois não apresentam correlação com estruturas preexistentes no basalto e seu } \\
\text { preenchimento composto apenas por material de alteração do basalto indica que estejam relacionadas a } \\
\text { um evento recente. }\end{array}$ & $\begin{array}{r}\text { Marques Filho e Levis } \\
\text { (1981) }\end{array}$ \\
\hline $\begin{array}{c}\text { Usina } \\
\text { Hidrelétrica de } \\
\text { Ibitinga (SP) }\end{array}$ & & $\begin{array}{l}\text { Em meio ao basalto maciço ocorre uma fratura sub-horizontal que varia lateralmente desde uma simples } \\
\text { junta até um horizonte fraturado de } 1 \mathrm{~m} \text { de espessura, que apresenta fragmentos de basalto e fraturas } \\
\text { preenchidas por minerais secundários, no qual são observadas estrias de atrito. Esta estrutura } \\
\text { corresponde a uma fratura de cisalhamento pós-magmática em que o cisalhamento aproveitou em parte } \\
\text { uma estrutura preexistente no basalto, já que a cristalização de minerais secundários em fraturas } \\
\text { normalmente está associada à circulação de fluídos tardi-magmáticos. }\end{array}$ & $\begin{array}{r}\text { Guidicini \& Campos } \\
\text { (1968) }\end{array}$ \\
\hline
\end{tabular}




\begin{tabular}{|c|c|c|c|}
\hline Localização & $\begin{array}{c}\text { Espessura } \\
\text { do derrame }\end{array}$ & Características principais & Referência \\
\hline $\begin{array}{c}\text { Usina } \\
\text { Hidrelétrica de } \\
\text { São Simão } \\
\text { (MG-GO) }\end{array}$ & $\begin{array}{l}\text { Subderrames } \\
\text { com espessura } \\
\text { total de } 20 \\
\text { metros }\end{array}$ & $\begin{array}{c}\text { Nos subderrames (e.g. derrames compostos) mais espessos (acima de } 6 \mathrm{~m} \text { ) são encontradas fraturas sub- } \\
\text { horizontais tardi-magmáticas de grande extensão lateral, formadas por um horizonte fraturado de } 50 \mathrm{~cm} \\
\text { de espessura, ondulado e definido por juntas pouco espaçadas, abertas e irregulares. Nos subderrames } \\
\text { menores as fraturas tardi-magmáticas ocorrem como uma única junta sub-horizontal com poucas } \\
\text { ramificações. }\end{array}$ & $\begin{array}{r}\text { Moller \& Cabrera } \\
\text { (1976), Moller \& Souza } \\
\text { Pinto (1976) }\end{array}$ \\
\hline $\begin{array}{c}\text { Usina } \\
\text { Hidrelétrica } \\
\text { Três Irmãos } \\
\text { (SP) }\end{array}$ & & $\begin{array}{l}\text { Uma fratura sub-horizontal em meio ao basalto maciço apresenta-se preenchida por minerais secundários } \\
\text { oriundos de percolação hidrotermal. Esta estrutura foi associada ao processo de fluxo da lava. No } \\
\text { entanto, seu comportamento notavelmente horizontal e sua característica como uma única junta de } \\
\text { grande continuidade lateral sugerem que tal estrutura possa relacionada à frente de resfriamento da lava } \\
\text { com o derrame estagnado e, dessa forma, correspondendo a uma fratura tardi-magmática. } \\
\text { Dois horizontes fraturados são encontrados nos limites das zonas estruturais do derrame. Essas estruturas } \\
\text { parecem corresponder a fraturas sin-magmáticas, apontado por Souza Jr. (1896) como falhas horizontais } \\
\text { primárias, devido à associação com diferenças texturais e estruturais primárias do derrame. } \\
\text { Neste local também foi encontrado em meio ao basalto maciço um horizonte fraturado definido por } \\
\text { blocos de basalto tabulares e em forma de lente, sem alteração, no qual se observa um deslocamento de } \\
20 \mathrm{~cm} \text {. Este horizonte, de espessura variável, apresenta certa inclinação e parece corresponder a uma } \\
\text { fratura de cisalhamento pós-magmática, possivelmente neoformada. }\end{array}$ & Souza Jr. (1986) \\
\hline
\end{tabular}




\begin{tabular}{|c|c|c|c|}
\hline Localização & $\begin{array}{l}\text { Espessura } \\
\text { do derrame }\end{array}$ & Características principais & Referência \\
\hline $\begin{array}{c}\text { Usina } \\
\text { Hidrelétrica de } \\
\text { Volta Grande } \\
\text { (MG) }\end{array}$ & & $\begin{array}{l}\text { Neste local ocorrem fraturas sin-magmáticas junto à base do derrame e na transição entre o basalto denso } \\
\text { e vesicular. Essas estruturas apresentam grande continuidade lateral (100 a } 200 \text { metros de extensão) com } \\
\text { ondulações de até } 2 \text { metros, acompanhando a atitude do contato. São formadas por um horizonte } \\
\text { fraturado composto por juntas abertas ou preenchidas por material de percolação hidrotermal. } \\
\text { Lateralmente essa estrutura pode se desenvolver como um só plano contínuo por até } 30 \text { metros de } \\
\text { extensão, com ondulações de } 2 \text { a } 5 \text { centímetros. } \\
\text { Relatos de fenômenos, como a abertura de contatos entre derrames e deslocamentos sobre fraturas sub- } \\
\text { horizontais preexistentes para fora do talude, que ocorreram alguns meses após as escavações foram } \\
\text { registrados no local da Usina de Volta Grande (MG). Estes fenômenos condicionam a formação de } \\
\text { fraturas pós-magmáticas como juntas de alívio e fraturas de cisalhamento sobre descontinuidades } \\
\text { preexistentes. }\end{array}$ & Brito (1971) \\
\hline $\begin{array}{c}\text { Usina } \\
\text { Hidrelétrica de } \\
\text { Ilha Solteira } \\
\text { (SP-MS) }\end{array}$ & 45 metros & $\begin{array}{l}\text { Na zona de transição entre basalto vesículo-amigdaloidal e basalto denso ocorre um horizonte fraturado } \\
\text { composto por blocos tabulares ou em forma de cunha, com ou sem preenchimento argiloso. Esta } \\
\text { estrutura está associada lateralmente a um bolsão de brecha argilosa de formato tabular e inclinado, de } \\
\text { até } 10 \text { metros de extensão. O horizonte fraturado parece corresponder a uma fratura sin-magmática, no } \\
\text { qual, sua associação com zonas de brecha no derrame pode estar relacionada à percolação de fluídos } \\
\text { hidrotermais tardi-magmáticos que se concentrem em descontinuidade preexistentes no derrame. } \\
\text { Neste local foi descrito na zona de núcleo do derrame um horizonte fraturado muito alterado que ocorre } \\
\text { na base de um bolsão de basalto amigdaloidal de formato irregular. O horizonte fraturado que ocorre no } \\
\text { basalto maciço parece corresponder a uma fratura de cisalhamento pós-magmática sobre uma estrutura } \\
\text { preexistente, já que estrias de fricção são verificadas no material de preenchimento das fraturas, } \\
\text { aparentemente oriundo de percolação hidrotermal. }\end{array}$ & $\begin{array}{r}\text { Oliveira (1969), } \\
\text { Camargo et al. (1971) }\end{array}$ \\
\hline
\end{tabular}




\begin{tabular}{|c|c|c|c|}
\hline Localização & $\begin{array}{c}\text { Espessura } \\
\text { do derrame }\end{array}$ & Características principais & Referência \\
\hline & & $\begin{array}{l}\text { No local da Cachoeira dos Índios foi observada em meio ao basalto maciço uma fratura tardi-magmática } \\
\text { caracterizada como uma junta de grande continuidade lateral no qual as colunas verticais apresentam } \\
\text { espessuras distintas acima e baixo dela e se iniciam perpendiculares a junta sub-horizontal. }\end{array}$ & Guidicini (1979) \\
\hline $\begin{array}{l}\text { Usina } \\
\text { Hidrelétrica de } \\
\text { Água Vermelha } \\
\quad \text { (SP-MG) }\end{array}$ & 30 metros & $\begin{array}{l}\text { Um horizonte fraturado com atitude sub-horizontal e de grade extensão lateral ocorre na base do derrame } \\
\text { que constitui o leito do rio. Este horizonte é concordante com a atitude geral dos derrames basálticos e } \\
\text { caracterizado como um extenso pacote fraturado com espessura variável entre dezenas de centímetros até } \\
\text { mais de um metro. O preenchimento das fraturas é composto por material predominantemente silto- } \\
\text { arenoso esverdeado (argilominerais), calcita e alteração de rocha basáltica, com espessura milimétrica } \\
\text { até cerca } 10 \mathrm{~cm} \text {. Esta estrutura parece corresponder a uma fratura sin-magmática, devido sua localização } \\
\text { na base do derrame e pelo material de preenchimento associado à percolação de fluídos hidrotermais. }\end{array}$ & $\begin{array}{r}\text { Midea et al. }(1975), \\
\text { Moura Filho \& } \\
\text { Sorregotte }(1975), \\
\text { Ussami et al. }(1976), \\
\text { Duó et al. }(1983)\end{array}$ \\
\hline $\begin{array}{l}\text { Usina } \\
\text { Hidrelétrica de } \\
\text { Porto Primavera } \\
\quad \text { (SP-MS) }\end{array}$ & $\begin{array}{l}\text { Subderrames } \\
\text { com espessura } \\
\text { total superior a } \\
60 \text { metros }\end{array}$ & $\begin{array}{l}\text { Neste local ocorrem horizontes sub-horizontais fraturados de grande extensão, com espessura média de } \\
0,8 \mathrm{~m} \text {, preenchidos com material argiloso e de alteração. Essas estruturas correspondem a fraturas de } \\
\text { cisalhamentos pós-magmáticas que ocorrem sobre estrutura preexistente como contatos e fraturas sub- } \\
\text { horizontais preexistentes no basalto, pois são verificadas estrias de atrito no material de preenchimento } \\
\text { das fraturas. }\end{array}$ & Marques et al. (1987) \\
\hline $\begin{array}{l}\text { Usina } \\
\text { Hidrelétrica de } \\
\text { Nova Ponte } \\
\text { (MG) }\end{array}$ & & $\begin{array}{l}\text { Um horizonte fraturado ocorre ao longo do contato sub-horizontal entre o derrame basáltico e o xisto do } \\
\text { embasamento. Ao longo do contato são encontradas falhas conjugadas, que cruzam o contato, } \\
\text { desenvolvendo-se ora no basalto ora no xisto, com rejeitos métricos. Essas feições desaparecem } \\
\text { lateralmente, restando apenas o padrão de fraturamento sub-horizontal sin-magmático na base do } \\
\text { derrame. Esta estrutura corresponde a uma fratura de cisalhamento pós-magmática que se desenvolveu } \\
\text { sobre o contato litológico aproveitando tanto a descontinuidade do contato, como o horizonte fraturado } \\
\text { sin-magmático preexistentes. }\end{array}$ & $\begin{array}{r}\text { Brito et al. (1990), Souza } \\
\text { Jr. (1992) }\end{array}$ \\
\hline
\end{tabular}




\begin{tabular}{|c|c|c|c|}
\hline Localização & $\begin{array}{l}\text { Espessura } \\
\text { do derrame }\end{array}$ & Características principais & Referência \\
\hline $\begin{array}{l}\text { Usina } \\
\text { Hidrelétrica de } \\
\text { Taquaruçu (SP- } \\
\text { PR) }\end{array}$ & 10 metros & $\begin{array}{l}\text { Neste local são encontradas duas fraturas de cisalhamento pós-magmáticas ao longo de contatos entre } \\
\text { derrames e uma fratura de cisalhamento pós-magmática que se desenvolveu sobre uma estrutura } \\
\text { preexistente no basalto maciço. Esta última é defina por um horizonte fraturado com } 20 \mathrm{~cm} \text { de espessura, } \\
\text { formado por fraturas sub-horizontais pouco extensas, alteradas e preenchidas por argila e material de } \\
\text { alteração do próprio basalto, no qual são encontradas localmente fraturas estriadas com atitude } \\
\text { condizente àquelas encontradas no contato entre os derrames. }\end{array}$ & Serra Jr. et al. (1986) \\
\hline $\begin{array}{l}\text { Usina } \\
\text { Hidrelétrica de } \\
\text { Itá (SC-RS) }\end{array}$ & & $\begin{array}{l}\text { Abaixo do leito do rio ocorre um horizonte sub-horizontal de basalto alterado e fraturado que desaparece } \\
\text { abaixo das margens. Esta estrutura parece corresponder a uma fratura pós-magmática associada ao alívio } \\
\text { de tensões devido à erosão e entalhamento do vale. }\end{array}$ & Infanti et al. (1999) \\
\hline $\begin{array}{c}\text { Usina } \\
\text { Hidrelétrica de } \\
\text { Nova } \\
\text { Avanhandava } \\
\text { (SP) }\end{array}$ & & $\begin{array}{l}\text { Neste local, são encontrados horizontes de rocha extremamente fraturada de grande continuidade lateral. } \\
\text { Os horizontes fraturados são pouco ondulados e possuem espessura entre } 10 \mathrm{~cm} \text { até } 3 \mathrm{~m} \text {. As fraturas que } \\
\text { compõe os horizontes fraturados apresentam preenchimento de material de alteração de basalto nas } \\
\text { frações granulométricas silte e argila, película de argila (cor branca e creme) e calcita soldando os } \\
\text { fragmentos tabulares de basalto compacto, conferindo à rocha um aspecto brechado. Essa estrutura } \\
\text { parece corresponder a fraturas de cisalhamento pós-magmáticas desenvolvidas sobre estruturas } \\
\text { preexistentes, já que são observadas estrias de fricção no material de preenchimento das fraturas, } \\
\text { provavelmente oriundo de percolação de fluídos hidrotermais, posteriormente sujeito a ação do } \\
\text { intemperismo. }\end{array}$ & Mano (1987) \\
\hline $\begin{array}{l}\text { Usina } \\
\text { Hidrelétrica de } \\
\text { Marimbondo }\end{array}$ & & $\begin{array}{l}\text { Fraturas de cisalhamento pós-magmáticas se desenvolvem sobre estruturas preexistentes como contatos } \\
\text { entre derrames e na transição entre basalto denso e basalto vesicular. }\end{array}$ & $\begin{array}{r}\text { Björnberg \& Kutner } \\
(1983)\end{array}$ \\
\hline
\end{tabular}

